Book Title: A Dutch Republican Baroque

Book Subtitle: Theatricality, Dramatization, Moment, and Event

Book Author(s): Frans-Willem Korsten

Published by: Amsterdam University Press. (2017)

Stable URL: https://www.jstor.org/stable/j.ctt1zxxxk0.13

JSTOR is a not-for-profit service that helps scholars, researchers, and students discover, use, and build upon a wide range of content in a trusted digital archive. We use information technology and tools to increase productivity and facilitate new forms of scholarship. For more information about JSTOR, please contact support@jstor.org.

Your use of the JSTOR archive indicates your acceptance of the Terms \& Conditions of Use, available at https://about.jstor.org/terms

This book is licensed under a Creative Commons Attribution-NonCommercialNoDerivatives 4.0 International. To view a copy of this license, visit http://creativecommons.org/licenses/by-nc-nd/4.0/. 


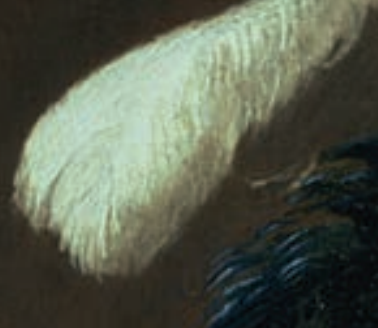

FRANS-WILLEM KORSTEN

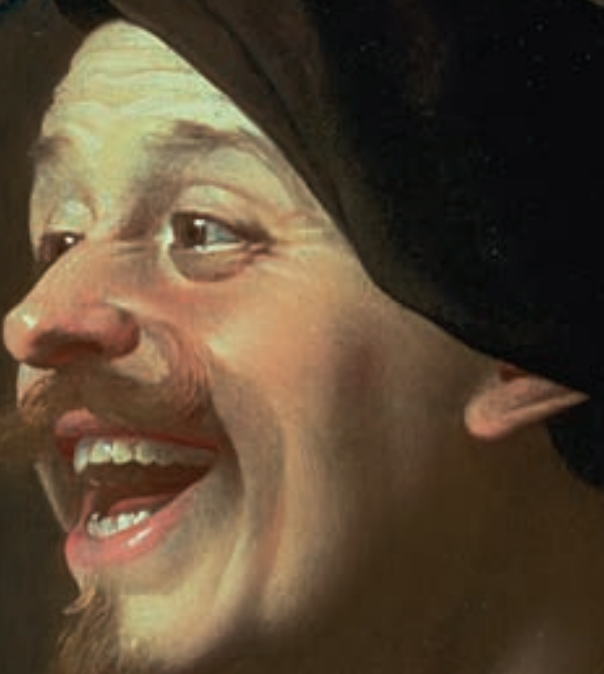

AbDutch Republican

Baroque
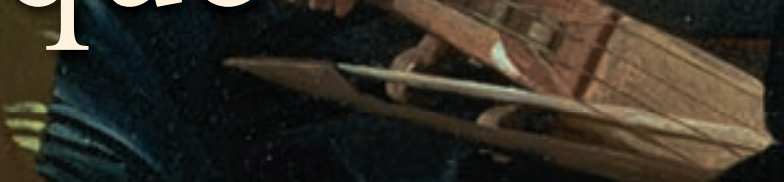

Amsterdam University Press 
A Dutch Republican Baroque

This content downloaded from 132.229.156.144 on Tue, 05 Feb 2019 10:42:31 UTC All use subject to https://about.jstor.org/terms 


\section{Amsterdam Studies in the Dutch Golden Age}

\section{Editorial Board}

Frans Blom, University of Amsterdam

Michiel van Groesen, Leiden University

Geert H. Janssen, University of Amsterdam

Elmer E.P. Kolfin, University of Amsterdam

Nelleke Moser, VU University Amsterdam

Henk van Nierop, University of Amsterdam

Claartje Rasterhoff, University of Amsterdam

Emile Schrijver, University of Amsterdam

Thijs Weststeijn, University of Amsterdam

\section{Advisory Board:}

H. Perry Chapman, University of Delaware

Harold J. Cook, Brown University

Benjamin J. Kaplan, University College London

Orsolya Réthelyi, Eötvös Loránd University Budapest

Claudia Swan, Northwestern University 


\title{
A Dutch Republican Baroque
}

Theatricality, Dramatization, Moment, and Event

\author{
Frans-Willem Korsten
}

Amsterdam University Press 
Cover illustration: Gerard van Honthorst, Laughing violinist, 1624

Cover design: Kok Korpershoek, Amsterdam

Layout: Crius Group, Hulshout

Amsterdam University Press English-language titles are distributed in the US and Canada by the University of Chicago Press.
ISBN $\quad 9789462982123$
e-ISBN $\quad 9789048532056$
DOI $\quad 10.5117 / 9789462982123$
NUR $\quad 685$

(C) F.W. Korsten / Amsterdam University Press B.V., Amsterdam 2017

All rights reserved. Without limiting the rights under copyright reserved above, no part of this book may be reproduced, stored in or introduced into a retrieval system, or transmitted, in any form or by any means (electronic, mechanical, photocopying, recording or otherwise) without the written permission of both the copyright owner and the author of the book.

Every effort has been made to obtain permission to use all copyrighted illustrations reproduced in this book. Nonetheless, whosoever believes to have rights to this material is advised to contact the publisher. 


\section{Contents}

1. Republican baroque: a thunderclap, a city hall and two executions 11

1.1. Artifice: multiple worlds and one actualized

1.2. Why a Dutch republican baroque; and why not a Golden Age? 18

1.3. City hall: affect — or what moves and what drives 23

1.4. Thunderclap: moment and event 28

1.5. Two executions: theatricality and dramatization 31

1.6. Republican baroque and slavery 37

2. The dramatic potential in history: Rome and the Republic -

Grevius, Vondel, Knüpfer, and Job

2.1. Two incompatible political models: transfer or disruption?

2.2. Allegory tied into a knot: history's continuity dramatically disrupted

2.3. Perverse powers, or how to make fun of the theater of torture 50

2.4. Catholic Rome and the figure of Job: subjection to the only possible world

3. The cruel death of worlds and political incompatibility - the brothers De Witt

3.1. Foundations of law: the master/father of a political house

3.2. The lynching of the De Witts: condensation and spectacle

3.3. The ship of state and the cruel political choice between incompatible worlds

3.4. Combat, the dramatic logic of cruelty, and the potential of difference

4. A happy split of worlds or the comedic sublime - Frans Hals

4.1. Happiness, the comedic, and the sublime

4.2. From Steen to Vondel: comical and tragic counterpoints to the comedic

4.3. The sublime intensity of the moment 
5. The seas or the world as scene - Focquenbroch and Grotius

5.1. Pre-colonial mise-en-abyme: Focquenbroch and a nonrepublican baroque 103

5.2. Moment of exchange and the non-existent 'proper' 108

5.3. Juridical staging: commerce and the seas 111

5.4. The precariousness of mise-en-scène 116

5.5. Amsterdam: city and sea as world scene 119

6. Not a frame but a lens: the touch of knowledge - Rumphius, $\begin{array}{ll}\text { Vossius, Spinoza } & 125\end{array}$

6.1. Spectacle or theater: Rumphius as knowledge-trader $\quad 125$

6.2. Nature internalized: res cogitans reconsidered 131

6.3. Sensing the world differently: the telescope 134

6.4. Reading through a lens: intensity and texture before scripture 141

7. Public theater, collective drama and the new - Van den Enden and Huygens

7.1. Theatrum mundi, public acting and the plane of collective imagination

7.2. Speaking for those who understand: a school drama in a theater

7.3. Dramatization: Theatrum mundi versus mundus dramaticus 163

7.4. Fluid borders between theatricality and dramatization: Huygens' 'Sunday'

8. Interrupting time for the sake of division: history and the tableau vivant - Rembrandt (Abraham and Isaac), Quast, Vondel, and Vos

8.1. Abraham and Isaac: the opening of history through the what-if

8.2. The virtual: narrative versus interruption

8.3. A fool waiting for the political moment: tableau vivant between retrospection and anticipation

8.4. The political potential in the tableau and the nature of freedom

8.5. Moment of closure: spectacle and a revolting tableau

Bibliography 201

$\begin{array}{ll}\text { Index } & 219\end{array}$

$\begin{array}{ll}\text { Index of names } & 227\end{array}$ 


\section{to my colleagues of the department FLW}

Now what is the meaning of 'one's real nature', from which one tries to appear 'different'? First answer: 'One's real nature' can be taken to be the sum of one's animal impulses and instincts, and what one tries to appear as is the socialcultural 'model' of a certain historical epoch that one seeks to become. Second answer: It seems to me that 'one's real nature' is determined by the struggle to become what one wants to become. - Antonio Gramsci, Selections from the Cultural Writings 


\section{Acknowledgments}

This book has been in the making for about five years. Some chapters appear for the first time in this book (Chapters 1, 5, and 9), other chapters have parts that are new. For the rest I used previously published articles: some almost entirely, some taken apart and distributed, and all reconsidered and when needed, rewritten. Most importantly, I reconsidered arguments and the precision of terms used in earlier publications in order to come to a more systematic consideration of the notions theatricality, dramatization, moment, and event. I thank editors and journals, in order of time of publication, for their permission to use or re-use: 'Moments of Indecision, Sovereign Possibilities: Notes on the Tableau Vivant' (part of chapter 8); 'The Invention of the Moment: Telescope, Literalness and Baroque Theatricality of the World' (part of chapter 6); 'Mundus Dramaticus: a School Drama and Dramatization - Franciscus van den Enden' (chapter 7); 'Rehearsal in Occurrent Art: Zdjelar's Don't Do it Wrong, One or Two Songs..., Shoum, Everything Is Gonna Be, and My Lifetime - Malaika' (a small part of chapter 5); 'What Roman Paradigm for the Dutch Republic? - Baroque Tragedies and Ambiguities Concerning Dominium and Torture' (chapter 2); 'The comedic sublime: the work of Frans Hals in a Dutch Baroque' (chapter 4); and 'Theatrical Torture versus Dramatic Cruelty: Subjection through Representation or Praxis' (chapter 3 and parts of chapter 2 and 8).

I am very grateful to a greater number of scholars than I can thank here. I thank Inge 't Hart and Tyler Sage as the intelligent, sharp, thorough, and attentive editors of this book. And I thank the peer reviewers of AUP and AUP's editorial board, especially Inge van der Bijl, Victoria Blud and Chantal Nicolaes. I want to thank my inspiring group of $\mathrm{PhD}$ students in Leiden as a whole, and more specifically those with whom I talked about chapters or who commented on some of them: Marijn van Dijk and Tessa de Zeeuw. Some of my PhD students became colleagues, meanwhile, and came to belong to the larger company of people with whom I conversed, at one moment or another, on the baroque or with whom I had the pleasure to write together: Mieke Bal, Jan Bloemendal, Joost de Bloois, Bennett Carpenter, Brian Cummings, Jan-Frans van Dijkhuizen, Martin van Gelderen, Lia van Gemert, Bram Ieven, Hanneke Grootenboer, Helmer Helmers, Olga van Marion, Marrigje Paijmans, Jürgen Pieters, Sara Polak, Freya Sierhuis, Nigel Smith, Kristine Steenbergh, René van Stipriaan, Maartje Wiersma, and Kitty Zijlmans. Then there were the participants in the NIAS meetings 
'Emotion and Subjectivity, 1300-1900' and 'Elevated Minds' organized by, respectively, Tara MacDonald and Kristine Johanson, and Stijn Bussels and Bram van Oostveldt. Finally, I have been happy to participate in the FWO/NWO funded project under the acronym ITEMP (Imagineering Techniques in the Early Modern Period). Here I am proud of being part of a Belgian-Dutch team with, respectively, Kornee van der Haven, Inger Leemans, Karel Vanhaesebrouck, and PhD students Yannice de Bruyn and Michel van Duijnen.

I thank the foundation Letteren en Samenleving Rotterdam for making it possible that I was allowed to hold the chair by special appointment 'Literature and Society' at the Erasmus School of History, Culture and Communication for a third term now. And I am extremely lucky to have found such a loyal, friendly, and professionally high level working place in Leiden with my colleagues from the Film- and Literary Studies department: Ernst van Alphen, Maria Boletsi, Eric de Bruyn, Yasco Horsman, Janna Houwen, Isabel Hoving, Madeleine Kasten, Liesbeth Minnaard, Pepita Hesselberth, Eliza Steinbock, Peter Verstraten, Astrid van Weyenberg, and, most recently, Jesper Doolaard and Mathijs Peters. It is in, and thanks to, their inspiring company that I was able to work on this book. I thank them for it. 


\section{Republican baroque: a thunderclap, a city hall and two executions}

\subsection{Artifice: multiple worlds and one actualized}

On 5 April 1654 a war between the Dutch Republic and the Commonwealth of England came to an end with the Treaty of Westminster. This did not solve the vast tensions between the Dutch and the English. Both remained armed to the teeth, as is illustrated by the vast amount of gunpowder retained for the Republic's land and marine forces, amounting to around 85.00o pounds in total. Stored surreptitiously in the south of the province of Holland, in the city of Delft, this cache became known as the Secreet van Holland. Secret or not, at 10:30 in the morning on Monday, 12 October of the very same year, this depot exploded, destroying one third of the city in a blast that was heard even on the isle of Texel, some 130 kilometers to the north. What came to be known as the 'Delft Thunderclap' struck unexpectedly. Whereas a devastating thunderstorm, a comet, or a great whale washed ashore could be read as signs of divine intervention, this was clearly a man-made event. ${ }^{1}$ The issue was not what God had wanted to convey with this disaster, nor was the question what it meant. Rather, the question was what had caused it and what it had done to a city, to an environment, to people.

The explosion killed hundreds, including the most talented pupil of Rembrandt, Karel Faber, better known as Carel Fabritius (1622-1654). On the occasion of his funeral, his friend Arnold Bon wrote a long poem that begins as follows: ${ }^{2}$

Battered, crushed and broken, in such a way in arms and legs that he was barely recognizable, almost without breath, Karel Faber was lying in the ashes, Due to the wicked powder; who knows inflamed by what?

1 On divine signs in the context of the Dutch Revolt, see Erik Jorink, 'Tekenen van Gods gramschap: Wonderbaarlijke natuurverschijnselen in de Republiek in de $16^{\mathrm{e}}$ en $17^{\mathrm{e}}$ eeuw' and 'Van omineuze tot glorieuze tekens. Veranderende opvattingen over kometen in de zeventiende eeuw'; or Jennifer Spanks and Charles Zika (eds), Disaster, Death and the Emotions in the Shadow of the Apocalypse 1400-1700.

2 In the following all translations are mine unless indicated otherwise. In order to make it easier to compare translations with the original text, I chose to stick to the interpunction in the original. 
His weary soul having cried itself entirely powerless,

Could just be saved from this terrifying misery.

Yet the all destroying and merciless death,

Has bitten through the thread of his life.

Thus the greatest artist went down,

That Delft or Holland ever begot. ${ }^{3}$

The difference could not be bigger between this crushed and broken body and a vibrant self-portrait made earlier in the year of Fabritius' death (see figure 1). ${ }^{4}$ The poem was an expression of personal grief. Yet, it also stated that an exceptional painter, 'the greatest' perhaps, had died. Fabritius' greatness consisted in his painterly ability to capture reality, and this was not only manifest in self-portraits but also city scenes, such as A View ofDelft from 1652, and his trompe l'oeils, or still-lifes, like the famous Goldfinch, also from 1654 . These paintings were made so skillfully that the subjects and objects depicted could be confused with reality.

The typical scholarly take on works like this has been that they play with the force of illusion and support the message that appearances deceive. Hanneke Grootenboer argued differently in stating that trompe l'oeils resist interpretation and meaning. ${ }^{5}$ To her the trompe l'oeil does not use the same perspectival, organizing vantage point which lends landscapes or city scenes a realistic depth. In contrast, the Dutch still-lifes did not have, or suggest, such depth but were rather about surface. In light of the circumstances, what had been a self-portrait of a living and lively Fabritius had now been turned into a still-life, as it were. He had become a body without depth, and the painting had acquired an uncanny quality as a result.

Considered together, the poem and the self-portrait may illustrate how with the Delft Thunderclap, for a split second, two different realities and worlds were possible: one in which Fabritius was alive, looking at himself, painting himself and rhetorically projecting his self, and another in which

3 In the original: 'Aldus gekneust, geplettert en gebrooken, / Aan arm en beenen dat onkenbaar was, / Lag Karel Faber schier versmoort in d'as, / Door't heiloos kruit; wie weet hoe aangestooken? / Zyn matte ziel gantsch magteloos gekreeten, / Wierd nog gered uit deezen bangen noodt. / Maar d'alvernield' en d'onmedoogde doodt, / Heeft hem den draad zyns leevens afgebeeten. / Zoo voer de grootste Konstenaar ten dale, / Dien Delleft ooit of Holland heeft gehad'; see Arnold Houbraken, De groote schouburgh der Nederlantsche konstschilders en schilderessen, p. 339.

4 The National Gallery's website states: 'Although no documented portrait of Fabritius is known, it is generally accepted that this is a selfportrait.' Because such a document is missing the official title now is Young Man in a Fur Cap, selfportrait; see: https://www.nationalgallery. org.uk/paintings/carel-fabritius-young-man-in-a-fur-cap; accessed 7 February 2017.

5 Hanneke Grootenboer, The Rhetoric of Perspective. 
he had been suddenly torn apart. As a result, the status of his self-portrait had changed. It now testified to a possibility, a life, cut short. And all of this was caused by two other possibilities of which only one had materialized. A spark simply fell to the ground and was quickly smothered without igniting anything, or this spark hit a portion of gunpowder after which its work could no longer be stopped. What precisely caused the disaster we do not know. The powder had exploded 'who knows inflamed by what?' The guardian, Cornelis Soetens, who was seen to enter the building with a lantern to get a sample of powder, was blown to pieces himself, so he could not tell. What was evident, though, was that this had no divine cause. It was an accident that illustrated the contingency of history. The contingency was related to the fact that human beings had come to play with the powers of nature, as a result of which they could artificially make or unmake a world.

The issue is central to a poem on the event by the Republic's major poet, Joost van den Vondel (1587-1679). It was entitled 'On the thunderstorm of the country's gunpowder in Delft'. The English term 'thunderstorm' suggests that this man-made event could be read as a natural disaster. Yet, the Dutch title 'Op het Onweder van 's Lants Bussekruit te Delft' is more ambiguous. The word onweder literally means 'non-weather'. Taken literally, the 'non-weather' connotes that this was like, but also unlike a natural event. This unnatural or man-made aspect is probed in the poem on the basis of two characters: one called Salmoneus and one called Black. The first was a mythological Greek king and supposed ruler of the isle of Elis, the second a Franciscan monk whose real name was Konstantin Anklitz, to which later generations added the nickname 'Schwarz': 'Black'. In Vondel's time, this Black was regarded as the thirteenth-century inventor of gunpowder. Both characters are connected to the poem's motto, taken from the Aeneid, which reads: plurima mortis imago: 'And many are the faces of death.' ${ }^{6}$ This refers explicitly to Black's invention and its unfathomable destructive powers; it refers implicitly to Salmoneus, for in book VI of the Aeneid Aeneas reports on his journey through the underworld. There he encounters Salmoneus, who is being punished and tortured for his crime of mimicking the gods.

Vondel's interest in Salmoneus had begun in 1653, when working on a play about the fallen angel Lucifer. ${ }^{7}$ In February 1654 Lucifer had been performed twice to great acclaim. Yet, the play was suddenly prohibited following fierce orthodox protest. However, several parties in the city had invested considerable sums of money in Lucifer, with its expensive scenery 
and stage-apparatus that represented the heavens. This investment now was lost, as was the envisioned profit. Thus, for practical reasons, and with a clear eye on the already made, expensive, and now useless scenery, Vondel decided to make a play about Salmoneus. The latter had theatrically turned the capital of Elis into heaven, in which he could appear as a god, so the Luciferian scenery that was supposed to capture a supposedly unrepresentable world, heaven, could now be used to turn the supposedly real city of Elis into the decor of heaven in which Salmoneus would mimic the gods. ${ }^{8}$

Precisely because he mimicked the gods, Salmoneus had already featured in the medieval Christian allegoresis of the Aeneid. As early as the twelfth century, Bernard of Silvester, for instance, wrote about Salmoneus in his commentary on the first six books of that epic:

Here, he signifies the tyrant and is so named Salmoneus, as if 'salmoneus', that is, the bringer of novelty. The tyrant brings novelty when he represents himself having divine powers transcending the human. ${ }^{9}$

The major sin of Salmoneus - to mimic the gods or God-was both a matter of bringing novelty and of his parading as one who had superhuman, divine qualities. Bernard makes this more specific when he remarks that mimicking the gods involved playing not only with the four elements but with lightning, thunder, and clouds as well. These elements form the connection with the second character in Vondel's poem: Black. The invention of gunpowder was something new that suddenly gave human beings powers that equaled, mimicked, or perhaps transcended those of the gods or God. With gunpowder, human beings could now unleash the forces of nature. They could artificially make 'lightning, thunder, and clouds'.

This is how Vondel reports on the disaster:

It was, learned Maarseveen, ${ }^{10}$

By no means Salmoneus, who in earlier times,

8 Salmoneus would not be the success that Lucifer had been. Its printed version, based on the produced play, appeared in 1657 after the first performance on 28 October 1657; see W.A.P. Smit, p. 185 .

9 Bernard Silvestris, Commentary on the First Six Books of the Aeneïd of Vergil, 109.8-110.2; also quoted in David Lawrence Pike, Passage Through Hell, p. 3o. It should be noted that Bernard's authorship of this text is disputed.

10 The poem was likely addressed to the Amsterdam burgomaster Joan Huydecoper Sr., Lord of Maarseveen, but perhaps also to his son. Having studied at the University of Leiden, he could, at age 29 , be called 'learned'. 
And recklessly so, in following the Almighty's trail,

With his torch in Elis mimicked

The thunderclap and streak of lightning,

And from a bridge, made of the brightest brass,

Propelled by pride gone to his head,

Came roaring down with copper wheels,

Like a wrathful God, and with a force

That dared take on heaven, earth, and Pluto's

Night, entirely on his own joking with them,

On his thundering wagon.

Yet even Salmoneus never had the guts:

The one from Denmark did have, Black,

15 Who, black from smoke and fume and coals,

Looked into the depth of nature, and opened up

All caves within her bosom,

And probed what was hidden in her heart.

He mixed saltpeter, coal, and brimstone,

That splits the abyss in its midst

Open from above, roars, fires,

And smashes the earth, and its intestines,

Castles, locks, and stones to pieces.

It rips the earth-tree from its roots,

25 Mixes living and dead,

And seems the heavens' crown

to challenge, by giving birth to such violence,

That all the hellish snake's hairs,

From horror of this war's element,

Raise themselves straight up, to the sky. ${ }^{11}$

11 Joost van den Vondel, De werken van Vondel, V, p. 821. Further references to the collected works of Vondel will use the standard Dutch abbreviation of $W B$, which is de Wereldbibliotheek version. 'Het was, geleerde MAERSEVEEN, / Geensins Salmoneus, die voorheen / Zoo stout, op 't spoor van d'Allergrootste, / In Elis met zyn torts nabootste / Den donderkloot en blixemstrael, / En langs de brugh, uit klaer metael, / Van hoovaerdye om 't hooft gezwollen, / Met kopre raden af quam rollen, / Als een verbolgen Godt, en kracht, / Die hemel, aerde, en Plutoos nacht / Alleen braveeren durf, en plaegen, / Op zynen donderenden wagen; / Noit had Salmoneus zoo veel harts: / Maer 't was de Deenemercker, Zwarts, / Die, zwart van roock en smoock en koolen, / Natuur doorgronde, en alle holen / Van haeren boezem openbrack, / En polste wat in 't harte stack. / Hy mengt salpeter, kool, en zwavel, / Dat scheurt den afgront tot den navel / Van boven open, buldert, brant, / En slingert aerde, en ingewant, / Kasteelen, sloten, steên te mortel. / Dat ruckt den aerdtboôm van zyn' wortel, / Vermengelt levenden en doôn, / En schynt den hemel naer 
Salmoneus is dealt with in familiar mythological terms. With Black the reader is transported into the caves of the natural world, which hold, if cleverly mined by man, a dramatic power that stands in contrast with the silly theatrical display of a king disguised as a god. In this context, the figure of Black has devilish connotations that are missing in the reckless Salmoneus. The effect of Black's work is 'hellish'. Whereas God mixed soil to make beings in which he could breathe life, Black mixed earthly material that destroyed life.

Yet, despite their differences, the two also have things in common. Salmoneus wanted to be equal to, or like, the gods, and Black appears to do something similar; as the text says, he appears to 'challenge the heavens' Crown'. Furthermore, both make use of technique, either used to defy the gods or to access and instrumentalize the powerful heart of nature. The theatrical roar of Salmoneus' carriage, with its copper wheels thundering over a metal bridge, is resounding, and translated to a spectacular level with the show and roar of the splitting, firing, smashing, ripping, mixing, birth-giving power of gunpowder. Put another way, whereas Salmoneus is theatrically mimicking the gods, and by implication challenging them, Black is dramatically challenging the gods, and by implication mimicking them. As a result, the two characters become entangled. Through playing with the divine world Salmoneus had dramatically probed its inner core and had found its inner secret, namely that the divine world was perhaps nothing but a matter of theatrical illusion. And Black had been a Salmoneus, in that he had dramatically found out nature's real secret and consequently been able to play, artificially, with the force of the gods.

To play with the illusory and the real in relation to artifice is not baroque per se; rather, the baroque confusion between the illusory and the real is due to the fact that the artificial may be real. Or, in other words, the baroque fascination with the powers of illusion centres not so much on how people can be fooled or tricked but on how illusions affect the real or are indistinguishable from it. ${ }^{12}$ In this context, Christine Buci-Glucksmann's contention that the baroque can best be seen in terms of a folie du voir, a 'madness of seeing', has become iconic. The phrase has also tended to have the unfortunate effect of reducing baroque to a visual spectacle. ${ }^{13}$ Still,

zyn kroon / Te steecken, door gewelt te baeren, / Dat al de helsche slangehairen, / Uit schrick voor 't oorloghs-element, / Te berge staen, en overendt.'

12 On the baroque as a period of illusion and paradox, see, for instance, Christine Buci-Glucksmann, La folie du voir or Le baroque littéraire, and Christine Buci-Glucksmann ed., Puissance de Baroque.

13 I am referring here to Christophe van Eecke, Pandaemonium, p. 18. 
Vondel's Lucifer was not condemned for playing with illusion or making a spectacle of the heavens, nor was the theatrical scenery used by Salmoneus a 'madness of seeing'. Theatrically speaking, it was transparent, its artifice obvious. The anxiety was that what for centuries had been projected as real, namely the divine nature of reality, was indistinguishable from illusion. At the time, the implication of this was enough, however, to make people mad in the double sense of the word: angry or on the verge of insanity.

When Walter Benjamin stated that the baroque theater 'has artifice as its god' he was to the point. ${ }^{14}$ Baroque theater structured forms of seventeenthcentury thinking. Thus, the very existence of human beings in the world was considered to be a matter of artifice. ${ }^{15}$ Whereas the term illusion suggests that one can fantasize about the moment when the illusion is lifted, as if awakening from a dream, the artificiality of the baroque is real in its ability to make, or destroy, a world, as in the case of the Delft Thunderclap. In accordance with this, French philosopher Gilles Deleuze, in his study The Fold: Leibniz and the Baroque, alluded to the seventeenth-century theater not as a place of illusion but as a space of immanence; a 'room without windows'. ${ }^{16}$ In such a space any world is what it is. There is no longer a viewpoint from the outside that implies the possibility of unveiling the appearance of a world for its falsity. We are, radically, in a world. There is no outside from which we could look at it or reflect on it.

In what follows I will come to define a republican baroque that manifested itself in the Dutch Republic in terms of the world's immanence. The question that poses itself then is how such an immanent world has come to be, or could come to be. The central thesis of this study is that the existing world is the result of a moment in which for a split second two or more realities are equally real and after which only a singular one becomes actualized. This is what explains the republican baroque's peculiar, specific vibrancy. The multiplicity of worlds is not a quantitative matter here, as if they are all illusory mirror images of one world. Rather, it is a qualitative one. The event of the Thunderclap suggests what man is capable of in relation to artifice, if we consider artifice in terms of make-ability: the make-ability of gunpowder in this case. Artificially made, it also has artificial powers to destroy, to unmake a world. Yet, as we will see, a world can also be made artificially, like the Republic itself. Or an architectonic miracle

14 Walter Benjamin, The Origin of German Tragic Drama, p. 82.

15 On the relation between baroque theatricality and worldview, see Helmar Schramm, in Karneval des Denkens.

16 The original is Gilles Deleuze, Le pli: Leibniz et le baroque. 
can be artificially produced, like the Amsterdam city hall. The hyphen in make-ability is meant to emphasize that it concerns truly, an ability: a term that connotes physical and mental power, that connotes both power and potential, and that emphasizes doing or acting. Such an ability does not depend on intention, on the contrary. No one really intended the make the Dutch Republic. It was the contingent effect of people acting.

\subsection{Why a Dutch republican baroque; and why not a Golden Age?}

There is something undoubtedly ironic about the term Dutch Republic. It was never a republic in the proper sense, and not designed as such either. When in 1581 the States-General, by means of the Plakkaat van Verlatinge or Act of Abjuration, said farewell to their rightful king, Philip II of Spain, the first attempt was to find a new sovereign. Due to a sequence of coincidences, this failed. So, the provisional states decided to work practically with the political bodies that were in place. The so-called Republic that thus came to life consisted first of seven sovereign provinces. These had feudal backgrounds as duchies, counties, lordships, or bishoprics, but were ruled in practice by urban regent families who formed an oligarchy of sorts. Whereas in a truly republican system public elections would be essential, in the Dutch Republic this was absent. What people opted for was checked by means of ruggespraak: obligatory consultation by the representatives of their urban constituencies. Whereas in a truly republican system there would be a well-designed institutional balance of powers-a system of checks and balances - this was poorly designed in the Dutch Republic. The checks and balances were more the result of messy practice.

The representatives of the provinces were in turn represented in a small political body: the States-General, residing in The Hague. It was mostly concerned with international affairs. Yet, in the course of the war with Spain the conquered territories to the south were added to the Republic as the so-called Generality lands, ruled by the States-General. Each sovereign province would appoint a stadholder, who would be in charge of that province's military affairs ${ }^{17}$ Yet, if most provinces, or all of them, would appoint the same man, he would have considerable powers, almost quasi-royal ones-as was the case in practice with the subsequent stadholders Maurits, Frederick Henry, William II, and William III. So, if this was a republic, it

On this complex structure, see Leslie J. Price, The Dutch Republic in the Seventeenth Century. 
is best understood in terms of what one of its great leaders, Johan de Witt, called 'true freedom': a form of rule not dominated by royal or quasi-royal powers but by the political, civil elites of a dense urban network, with Amsterdam as its undisputable center.

It is no surprise, then, that the Republic, or one of its iconic figures, Benedict de Spinoza, has been defined as an 'anomaly'. ${ }^{18} \mathrm{An}$ anomaly depends, of course, on a general picture that defines what is normal. In the context of my dealings with the Republic in baroque terms, the so-called normal is evidenced in introductory works such as Victoria Charles and Klaus Carl's Baroque Art, in which the chapter 'Baroque in the Netherlands' ignores the differences between the Republic and the Spanish Netherlands and portrays their Baroque as just one specimen of a general European phenomenon. ${ }^{19}$ Babette Bohn and James M. Saslow consider baroque 'opulence and grandiosity far less applicable to Dutch genre painting. ${ }^{20}$ Likewise, Fred S. Kleiner concludes: 'Indeed, the stylistic, as opposed to the chronological, designation "baroque" is ill suited to these seventeenth century northern European artworks'. ${ }^{21}$ Christopher D.M. Atkins joins a familiar chorus in asserting that the term baroque in a stylistic sense 'does not adequately describe Dutch aesthetics or the cultures of the Dutch Republic'. ${ }^{22}$ This all begs the question whether, and if so how, one should or could adequately describe a Dutch republican baroque.

Firstly, while the baroque has generally been associated with the religious battle between a protestant reformation and baroque catholic contra-reformation, the Dutch Republic brought to life a partly catholic but in the end worldly baroque. It was worldly in the sense that a number of artists, merchants, politicians, scholars, and thinkers were fascinated by the dramatic wonders of the real. ${ }^{23}$ It is this 'real' itself that for the first time gets its modern aura of being both hidden and present due to its principally contingent nature. For if the world could have been so different, what was the nature of the world that had been actualized in the shadow of the ones that were not? For radical thinkers in the Dutch baroque, but also, in a

\footnotetext{
18 Antonio Negri, The Savage Anomaly.

19 Klaus H. Carl and Victoria Charles, Baroque Art, pp. 66-153.

20 Babette Bohn and James M. Saslow, A Companion to Renaissance and Baroque Art, pp. $5^{-6 .}$

21 Fred. S. Kleiner, Gardner's Art Through the Ages, p. 703.

22 Christopher D.M. Atkins, The Signature Style of Frans Hals, p. 18.

23 I consider the title of Mariët Westermann's study on art in the Dutch Republic to be well chosen: A Worldly Art: The Dutch Republic 1585-1718. This finds an analogy in the title of René van Stipriaan's study on literature and culture of the Republic: Het volle leven, that is: 'the rich or abundant life', or 'life in its density'.
} 
practical sense, for people of many trades, to deny the reality of a world as opposed to possible other ones, would have to imply that human beings were not free, because they lived in the only possible world. As such the Dutch republican baroque stood in direct opposition to the powerful Calvinist ideas of predestination.

Second, the baroque has generally been defined in relation to sovereign rule, whether it be papal, princely, or royal. In contrast, in the Dutch Republic two different types of baroque came to exist alongside one another. ${ }^{24}$ Due to the quasi-royal character of the Dutch stadholders, especially Frederick Henry, there was a princely baroque that came to exist next to a republican one. The latter answered differently to common baroque characteristics such as the hallucinatory or illusory multiplicity of worlds, paradox, fragmentation, exuberance, self-reflexivity, or artificiality. For instance, instead of a hallucinatory multiplicity of worlds meant to express or connote the ruler's mystery, the republican baroque implied a materially real multiplicity of worlds. Though few during this period could make it explicit, the world was experienced in baroque terms as the one actualized out of a myriad of possible worlds. Thought through, or better, sensed through to its consequences, what was at play was ultimately not a matter of illusion or mystery. Instead one found oneself conscious of the fact that a multiplicity of realities had been actualized into one. The Republic was a good case in point. It had come to be by mere coincidence and contingent events. All in all, the Republic, in becoming active, stumbled into a world that it helped to make at the same time. It fused an awareness that the world could be made artificially with an awareness that the contingency of history was not fortunate or accidental, but, politically speaking, foundational. Its very contingency entailed freedom. ${ }^{25}$

Third, aesthetically speaking, a Dutch republican baroque does not fit in easily with studies that place the baroque as one period in between the Renaissance and Neoclassicism. Moreover, it redefines the strong opposition, also used by Nietzsche in Human All Too Human, between baroque and classicist art. ${ }^{26}$ The two coexisted fraternally or sororally next to one another in the

24 On such a definition of the baroque, especially in the visual arts, see Alain Mérot, Généalogies du baroque; for an overview of the uses of the term baroque, see Michel Conan, 'Introduction: The New Horizons of Baroque Garden Cultures'.

25 I refer, here, to a study by Quentin Meillassoux, Finitude: An Essay on the Necessity of Contingency.

26 The opposition is still operative. When Michael J. Horswell considers 'the early modern period's baroque and the later neo-baroque as a challenge to, or crisis of, ... unfinished modernity,' he gives an overview of the field of neo-baroque studies and contends that scholars have read recurrent baroque elements in culture 'as an 'ethos' or 'spirit' that inevitably disrupts cyclical 
French baroque, as Jean Rousset noted. In the Republic, however, the two were both in conflict and in embrace. ${ }^{27}$ This aesthetically conflicting and entangled mixture of styles, however, was distinctly baroque itself, because baroque is defined by paradox and mixture, and works by means of entanglement.

Fourth, socio-culturally speaking, the Dutch republican baroque concerns a seventeenth-century, opulent, and grandiose society of many cultures. The daily reality throughout the Republic, or in its hub Amsterdam, could well be described as a matter of what art theorists called misto at the time: a mixture of styles (not to be confused with tolerance), defined by some as a 'Tower of Babel', that resulted in a baroque atmosphere. ${ }^{28}$ When I stated earlier that this baroque was worldly, this also indicates that, despite religious controversies, this type of baroque should be defined on the basis of the material form and organization of a world. Though the baroque worldliness of the Dutch Republic was, in some aspects, deeply religious, it was also radically material or empirical, as in the work of Spinoza. ${ }^{29}$

In what follows I will be dealing, amongst other people and things, with playwrights and poets (Vondel, Vos, Focquenbroch), painters (Fabritius, Brisé, Knüpfer, Verschuier, Hals, Rembrandt, Quast), politicians (Maurits, Oldenbarnevelt, the brothers De Witt), ministers (Grevius), scholars, scientists and philosophers (Rumphius, Grotius, Vossius, Spinoza), freethinkers, educational innovators and activists (Van den Enden), buildings (the Amsterdam city hall), ships and seas, characters (Job, Abraham, Isaac), tableaux vivants, treatises and street songs. Some of these have been dealt

pulls to orderly, classical aesthetics;' Michael J. Horswell, 'Baroque and Neo-baroque Literary Tradition'.

27 Jean Rousset, La littérature de l'age baroque en France. p. 234. See also John Rupert Martin, Baroque. On the simultaneous manifestation of classicism and baroque in specifically Dutch works of art, see Ebeltje Hartkamp-Jonxis, 'Mannerist, Baroque, and Classicist' or my Sovereignty as Inviolability. A good case in point is the Republic's iconic author, Joost van den Vondel, who was first received as baroque in Catholic circles, then in the second half of the twentieth century as a classicist, while in this last decade he has been considered as a mixture of both. For this, see the already mentioned Sovereignty as Inviolability. For Vondel's baroque qualities, see Gerard Brom, Vondels geloof, W. Kramer, Vondel als Barokkunstenaar.

28 On the term misto or acutezza, see Maria H. Loh, 'New and Improved: Repetition as Originality in Italian Baroque Practice and Theory'. Markus Vink, in a review of August den Hollander (e.a.), Religious Minorities and Cultural Diversity in the Dutch Republic, characterizes the atmosphere in terms of 'the dialogic processes at work in the religious Tower of Babel that was the Dutch Republic'.

29 On the radical and radically empirical nature of Spinoza's work, see Jonathan Israel, Radical Enlightenment, and Enlightenment Contested. Margaret Jacob's The Radical Enlightenment had already coined the term in the context of Freemasonry; see also Andréa Kroon, 'Masonic networks, material culture \& international trade'. 
with explicitly in baroque terms, like Vondel, Vos, Hals and Rembrandt. Others are not at all, or less well, known as baroque (eg. Spinoza, Rumphius). I could have included many others. Yet, this study is not so much concerned with formally deciding who or what was republican baroque and who or what was not. It rather aims to reconsider all sorts of actors, entities and things in the light of a republican baroque that can be described in terms of period, style, or sensibility, but better, as the term 'republican' suggests, as a politico-aesthetic attitude or mode of being in the world..$^{30}$

This attitude can be traced amongst all sorts of actors, situations, and objects and through all sorts of domains. I will be looking at works of art, literature, and theater, yet my study attempts to answer a more general question of how we can understand the Dutch baroque as republican by focusing on what it was driven by, how it affected people, and how it came to embody a scene, which was not so much a scene in the world, but the world as scene (see chapter 5). Both politically and aesthetically, the Dutch republican baroque forces us to reconsider the baroque as principally split, with a religiously or royally spiritualized version on the one hand, and a worldly, republican and material baroque on the other. ${ }^{31}$

I will be considering this republican baroque in terms of praxis and this implies a refusal to read it, in terms of the nineteenth century or royal appropriation of the seventeenth century, as a 'Golden Age'. Not only was there a lot that was not 'golden' at all, as we will see in the final section of this chapter, the very phrase 'Golden Age' might veil the fact that the Dutch Republic was not the solution to a political problem. It rather posed the problem of the political. Being ruled by a king first, the Low Countries had to solve the problem of how to rule themselves. With the coming into being of the Dutch Republic they did not solve this problem, but kept it alive, in terms of messy practice. This did not mean everything was a mess. In fact the practice proved to be highly productive and creative. A building that illustrates, or rather embodies this, is the Amsterdam city hall.

30 For a definition of the baroque as sensibility, see Robert Mandrou, 'Baroque Européen'. Mandrou also considers the revolutionary potential inherent in the Baroque.

${ }_{31}$ This reconsideration is not just of relevance with regard to the seventeenth century but also in relation to recent reconsiderations of the Baroque. Witness such studies as Gregg Lambert, The Return of the Baroque in Modern Culture; Mieke Bal, Quoting Caravaggio; Angela Ndalianis, Neo-Baroque Aesthetics and Contemporary Entertainment or William Egginton's The Theater of Truth: The Ideology of (Neo)Baroque Aesthetics. For a study into the confrontation between the historical conceptualization of the Baroque and contemporary usages of the term, see Helen Hills, ed., Rethinking the Baroque. In this context other paradigmatic studies are Christopher Braider, Baroque Self-Invention and Historical Truth; or Lois Parkinson Zamora and Monika Kaup, Baroque New Worlds. 


\subsection{City hall: affect —or what moves and what drives}

The Amsterdam city hall was officially opened on 28 July 1655 , only nine months after the Delft Thunderclap. It was planted, like a giant, in an urban environment of relatively small houses, and as an astonishing expression of civil power, incomparable with anything built in Europe at the time..$^{32}$ It was an out-of-proportion, mind-blowing baroque building that was defined as the eighth miracle of the world by Constantijn Huygens, who addressed the burgomasters of the city as 'Enlightened founders of the world's eighth wonder / of so many stones up high, and so much wood down under'. ${ }^{33}$ In structure and outward appearance the building was distinctly classical, only to reveal a decorative baroque interior. One practical motivation for its construction, was that the former city hall had caught fire and was burnt to the ground. A more powerful motivation was that the city of Amsterdam wanted to show its position in the world that it had helped bring into being. The building, and by implication the world it stood for, was not made by quasi-divine sovereign powers or rulers. Amsterdam was republican itself, as the Republic's financial and commercial center and as the center of the Republic's true political power.

Amsterdam as the Republic's financial and commercial center is captured paradigmatically by a trompe l'oeil that was made by Cornelis Brisé for the room in which the Thesaurie ordinaries held office: the treasury chamber, the center of financial organization and public affairs (see figure 2). In order to assess the affective powers of this work it may be relevant to know its size. In sharp contrast with Fabritius' The Goldfinch, which measures 33.5 by $22.8 \mathrm{~cm}$, this work measures 192 by $147 \mathrm{~cm}$. In the context of a republican baroque, it is telling that the painting was taken from its proper place and moved to Amsterdam's Stedelijk Museum in 19o6. If nowadays the city hall is called Royal Palace, this is because it was confiscated during the short reign of Napoleon's brother, Louis Napoleon, from 1806 to 1810 . After the return of William Frederick VI of Orange-Nassau, who would become the first and self-appointed king of the Netherlands as William I, the building's change in status (or should one say its appropriation) became a matter of

32 As Frijhoff and Spies suggest in Dutch Culture in a European Perspective, the Amsterdam city hall was 'perhaps too big...' ('te groot misschien...') p. 441.

33 'Doorluchte stichteren van's wereld achtste wonder, / van soo veel steens omhoogh, op soo veel Houts van onder', Constantijn Huygens, Gedichten, deel 6: 1656-1661, p. 108. No building in Amsterdam would still be standing straight if it had not been underpinned by wooden poles piercing the first weak and wet layer of soil to let the building rest on the firmer soil underneath. The city hall was built on 13,659 wooden poles. 
fact. The treasury chamber would become the bedroom of a queen, which is why the painting had to be moved.

When the city hall was still the heart of a republican world, Brisé's painting hung underneath a painting by Nicolaes van Helt Stockaden, depicting Joseph, the humble shepherd boy who had become vice roy of Egypt, distributing corn to the people in an act of justice and equality. ${ }^{34}$ Brisé's painting was the only painting in the entire city hall that did not have a historical, mythological, or biblical theme. Or, it was the only painting that was explicitly 'for real'. The Republic's major poet, Joost van den Vondel, wrote extensively about this newly built, artificial yet real miracle in a poem entitled 'Inauguration of the city hall in Amsterdam'; 35 he was deeply involved with the themes of the art that was to decorate the inside; and he wrote some of the epigraphs for these works, as he did for this remarkable piece. Only the last two lines are generally quoted. This is the entire poem:

People shouted, the arts of print and writing will go out of control Now that Holland forbids us to use French paper.

Don't let yourself be bothered, Amsterdam's Thesaurus stated

Once Brisé begins to paint, he will provide paper.

$5 \quad$ Look at this scene; what do you see up high?

Papers, act and letter: or appearance deceives our eye. ${ }^{36}$

As one may see, the painting is related to the real world of real problems. Specifically, it concerns the threat to the Dutch paper market posed by cheaper French paper, against which measures of protection had been taken ${ }^{37}$ The text then continues to suggest - as a straightforward or tongue in cheek joke - that the Amsterdam treasury could deal with this economic problem by ordering paper to be painted. In this way, instead of hinting at the cliché that all may simply be illusion or deception, the poem (along with

34 See 'Stadhuis Paleis op de Dam. Thesaurie. Functie. Inhoud.'; https://17burgers.wordpress. com/2013/05/o3/stadhuis-paleis-op-de-dam-thesaurie-functie-inhoud/

35 See Joost van den Vondel, Inwydinge van 't stadthuis t'Amsterdam (eds. Saskia Albrecht, Otto de Ruyter, Marijke Spies, Frank Elsing, Winny Hübben en Marianne Stegeman).

36 In the original: 'Men riep, de Drukkonst en de Schrijfkonst zal verwildren / Nu Holland ons verbied 't gebruik van Fransch papier. / Ontsla u van dees zorg, sprak Amstels Trezorier / Brizé bestelt papier, als hij zich zet tot schild'ren. / Bezie dat Tafereel; wat ziet gij daar omhoog? / Papieren, bul en brief: of schijn bedriegt ons oog.' See A.J. van der Aa, 'Cornelis Brize', Biographisch woordenboek der Nederlanden. Deel 2, p. 1337.

37 On this see Karel Davids, 'Technological change and the economic expansions of the Dutch Republic 1580-1680', or G.C. Gibbs, 'The role of the Dutch Republic as the intellectual entrepôt of Europe in the seventeenth and eighteenth centuries,' p. 324. 
the painting) confronts us with the real power of paper. One might even say that both confront us with paper's slightly sur-real power, on which, indeed, the entire work of the Amsterdam Treasury depended.

In the everyday world of the Republic, all were affected by the power of paper. Having papers or not could make the difference between ending up in one world or another. The treasury could check or issue papers that shaped reality. In this context the painting is a telling sign of paper's power in the affective organization of reality, its density, or its multiplicity. Isolating the last two lines of the poem to indicate that this painting was only supposed to emphasize the illusory status of the real misses the point. Brisé painted papers not to show how illusory they were but how great their real force was. He was not so much representing realities as presenting them, making them palpable.

Hanneke Grootenboer argued that the Dutch trompe l'oeil had no real vanishing point, or no depth, and this painting is an excellent case in point. The painting shows papers on a wooden board, but is not arranged according to the rules of perspective and depth. Consequently, as Grootenboer noticed, the vanishing point is conflated with the point of view of the viewer: we move on the surface; there is nothing 'behind it.$^{8}$ In this context, the last lines of the poem should be read differently. The question 'Do you think you see real papers?' has commonly been answered with: 'No, this is only a trick of vision.' I suggest the better answer is: 'No real papers perhaps, but you see the near-magical powers of artificial papers to make the real.' The painting is analogous to the status of (paper) money and contracts, here. These are not illusory. They are producing realities.

Often, and perhaps a little too often, scholarly attention has focused on the epistemological after-effect of the trompe l'oeil: that it makes people ponder or think. Yet Brisé's papers are more artificially present than representing, as Grootenboer argued, and they struck, and still strike, viewers immediately.9 In my reading, Dutch trompe l'oeils like this one were not so much supposed to confront the viewer with deception, then, but had such an affective charge because of an intensity that depended on the maker's and viewers' deeply felt, active connection with reality. As such the paintings were not being merely descriptive. ${ }^{40}$ Nor were they strictly rhetorical. They

38 Hanneke Grooetenboer, The Rhetoric of Perspective, pp. 54-59.

39 Deleuze's take on affect is specific. For an overview of different affect theories, see: Melissa Gregg and Gregory J. Seigworth, eds., The Affect Theory Reader.

40 I am referring to the thesis developed by Svetlana Alpers in The Art of Describing. 
affected people in such a way that it effectuated an 'ensnarement with the world', as Norman Bryson defined it. ${ }^{41}$

When the previously mentioned Gilles Deleuze developed his theory of affect, he did so, tellingly, in relation to the baroque, especially in relation to the work of Benedict de Spinoza. ${ }^{42}$ The latter was 21 at the time of the Thunderclap, 22 at the time city hall opened, and already a highly controversial figure in the Amsterdam Jewish community (he would be excommunicated a year later, on 27 July 1656). In Spinoza's work, affect is central, as when he states that bodies of whatever kind cannot be defined in terms of their essence but rather in terms of what they are capable of, in terms of their powers to affect and be affected. Such affective powers may differ in complexity and intensity. A stone, for instance, has affective powers: powers to affect and be affected. And as this example may make clear, affects do not have a concrete message, content, or meaning. A stone may affect a mouse in protecting it or hurting it, but this does not imply that it 'means' protection. It may affect a human being in attracting attention as a thing of beauty, as something to be kicked aside, or as material to be used in a building. Affects, then, in Deleuze's reading of Spinoza are nothing more or less than meaningful media in a material, bodily, socio-neural network defined by intensities. This is how Deleuze specifies it:

Every mode of thought insofar as it is non-representational will be termed affect. A volition, a will implies, in all rigor, that I will something, and what I will is an object of representation, what I will is given in an idea, but the fact of willing is not an idea, it is an affect because it is a nonrepresentational mode of thought. ${ }^{43}$

To have a proper understanding of what Brisé's trompe l'oeil is doing it might be of relevance to see it as both representational and non-representational. Clearly the painting depicts papers. Yet it affected people in a society driven by an economy in which paper contracts, shares, charters, etc. played a dominant role.

Emotions and affects can be defined best, in this context, based on a distinction between what moves and what drives. It is a distinction that is

41 Norman Bryson, Looking at the Overlooked, p. 117.

42 Some scholars tend to refer to him as Baruch de Spinoza since he was Jewish in birth. However, since he was kicked out of the Jewish community he had to give himself a new name, to which I will stick: Benedict.

43 Gilles Deleuze, 'Deleuze on Spinoza'. 
often not made in seventeenth-century theories of the passions. The terms passion and affect are dominant. So, if we bring in emotion it should be to further understanding and sharpen definitions. In what follows, going back to its etymology, emotion is derived from the Latin emovere. Consequently, emotions serve to indicate everything that moves people. Affect relates to what drives people. One can be affected, resulting in a change in feeling, as is expressed in the phrase 'That moved me'. Yet, such 'being moved' does not mean that one is being driven. Following Spinoza, affects concern the basis of life in general — organic and inorganic — and form the force field that determines the dynamics in any body, be it natural or political. Every being consists in its potential to affect and to be affected. ${ }^{44}$

For someone who is simply unaware of the fact that paper can have value, or for someone who has no idea of what money could be, the affective charge of paper is radically different than for someone who recognizes certain pieces of paper as financial guarantees. For the former, the piece of paper might as well be used to ignite a fire, whereas for the latter the same piece of paper may provoke strong feelings of desire, luck, or anxiety. Brisé's painting shows a fascination, here, with the intensive appearance of the artificial reality of a world. Again, whether the things represented were a small bird, a bend in the road, or a collection of papers, they could all affectively 'bind' viewers. Such an aesthetic binding force would precede a more emotional, or rhetorical, effect. It would not be captured or framed by a narrative plot but was understood in the context of a living environment. Brisé's painted papers did not simply produce trust in paper, here. His painting was made in the context of a society that was based on contracts in which papers were formally and meaningfully basic. In relation to this, emotions played a role. People would be happy if their papers were worth more than originally thought, and would be in despair if the market collapsed. They would feel anxious if they had lost important papers, or would desire to have the right papers. Yet, apart from such definable emotions, these artificial papers had ontological powers; they were able to change bodily existences, situations, and lives.

Briefly put, instead of presenting its audience with a subject that was theatrically put at a distance, or that was illusory, the painting dramatically presents a subject that asks viewers to ponder the powers of reality

44 For a good overview of the notions affect, feeling and emotion, see Ernst van Alphen, 'Affective Operations of Art and Literature'. My dealing with the notion of affect is influenced, next to Deleuze, by Sara Ahmed, The Promise of Happiness, and Lauren Berlant, Cruel Optimism. Although especially Ahmed inscribes herself in another lineage of affect theory, her ideas on the 'drama of contingency' relate to pivotal issues in my study; see Ahmed, p. 24. 
as artificial. With this I have brought in the notions of the dramatic and the theatrical again. Before I focus on them separately, I need to detour, however, via the notions of moment and event.

\subsection{Thunderclap: moment and event}

The Delft Thunderclap was represented in several paintings made by the Delft-based painter Egbert van der Poel (1621-1664). While working on the paintings, he was probably thinking of his daughter whom he had lost in the blast as well. In his later years he would become an expert in painting night scenes, with houses on fire. The painting shown as figure 3 , which represents the Delft Thunderclap, is just one of twenty paintings on the subject, all made by Van der Poel. As a representation of what had happened, this particular painting re-stages theatrically what has already become an event. We see people helping victims and carrying away rubble. In the middle of the painting, a cloud of dark smoke slowly disappears into the sky. At the very right, a figure, the man in the hat and cloak, emphasizes the theatrical frame of this painting. He is already watching a scene that now has become, indeed, theatrical, as a result of which the viewer of this painting can also act as an audience in the sense that they can be moved by it.

As the representation of an event that can now be seen and re-staged theatrically, the painting above is different from the one entitled View of the Delft explosion (see figure 4). Here we are in the moment of the explosion, or rather just a few moments after the great Thunderclap, since the environment has already been destroyed. Perhaps this is the fifth and final blast (there were five explosions in total, differing in strength). No one is functioning as the icon of an audience. Only people in the moment of dramatic action are represented. Obviously, an audience standing in front of the painting will see it as the representation of an event, and in that sense the painting is theatrical. As for the actors in the painting, they are in the midst of actions that they do not yet grasp. They must be undergoing many deep emotions, but their actions are determined more, or more basically, by affects. In a split second, something radically changes and this affects them, immediately. It is only with hindsight, then, that people will start to describe what happened to them in terms of emotions, as a result of which others can be moved. Yet, in terms of affect they are in the midst of something dramatic happening. This is not so much moving, emotionally, as changing the state of affairs, physically and psychically, bodily and mentally: affectively. 
On this painting, as well as on others depicting the Thunderclap, Egbert van der Poel wrote his name and the date on the left lower corner: Evander Poel den 12 ocktober 1654 . Obviously he could not have made the painting on the spot, for the simple reason that he would have been blown away. In going back to the date and the moment, all his paintings are in a sense restagings, and therefore theatrical. Still, as re-stagings they also bring us back to a moment at which a dramatic split took place between two coexisting realities, with tragic consequences - a moment that we can no longer enter but only sense, affectively, in an almost sublime way. And as will become clear when I deal with the works of Frans Hals in a later chapter, such a dramatic split need not be tragic. It might also be a happy, or comedic one.

I would like to reserve the term 'moment' for people acting amidst things without any clarity as to what is actually happening, other than sensing, being aware of the fact that something new is brought into being in a split second coincidence of multiple realities, only one of which will be actualized. Although such a moment is highly emotionally charged, these emotions are not (yet) manipulated. They are experienced in a moment of affective intensity or disruption. As will become clear in following chapters, with the moment the political becomes a potential for not just changing an existing world, but actualizing a new one, or closing down another. For the realization that something has become a known reality, and consequently can be reflected on or be re-staged, I reserve the term 'event'. 45 The split second moment of coexisting realities has passed, and we can now speak, with hindsight, of a changed situation in what has become one irrevocably separate reality. ${ }^{46}$ With hindsight, due to the shift from moment to event, emotions can now be manipulated, and the event itself is inscribed into a preexisting affective force field. The dynamic at stake leads me to the following chiastic formulation:

The moment intensifies or opens up a world in either breaking an existing frame or in actualizing something that only with hindsight can be framed as an event;

the event closes down or frames what previously has been a worldopening moment, and in its potential of being restaged and represented embodies the potential of an opening moment.

45 My study is a response, in this context, to Alain Badiou's The Logic of Worlds.

46 My dealing with the concept of the event is indebted to narratology. An event is defined, there, as the change from one situation into another. See Mieke Bal, Narratology. 
Whereas histories (or plots) are shaped by the sequence of events, it is through moments that historical possibilities are opened up and can be revisited to explore the status of a particular world as one out of many possibilities. When in one of his last lectures Jacques Derrida stated that 'an event implies surprise, exposure, the unanticipatable, ${ }^{47}$ this was an unfortunate mixing up of the terms event and moment. Or, it was a surprising confusion considering Derrida's fascination with the etymology of terms. Event is derived from Latin evenire, which means 'to come out, happen, result'. Especially this last meaning stands in contrast with the notion of moment, which is derived from Latin movere: 'to move, set in motion, remove, disturb'. In its etymological history 'moment' comes to indicate a minute time divison. 'Moment' is a matter of division, then, (or of bifurcation as we will see), as a result of which something is intensified for its potential and momentous affective powers.

Of late, the relation between event and moment has also been taken up by Daniel Arasse in Anachroniques and by Alexander Nagel and Christopher S. Wood in Anachronic Renaissance. In both cases a specifically Renaissance aesthetic dynamic is at stake. Renaissance artists would reconfigure the linearity of history by means of a play with intertextuality: text and intertext establish the simultaneous presence of two historically distinct time periods. The moment is related, here, to the linearity and chronology of one world that is historically different in time and in which two historical moments are brought together textually. In contrast, the Dutch republican baroque moment is one at which differing worlds meet. Put another way, here, the moment relates to a plurality of equally real worlds that meet at a singular point in time. If there is a connection with the Renaissance, it would be through the work of Machiavelli, for whom 'moment' was a pivotal political notion. The moment, to him, is a coincidence of contingency and determination, with contingency embodying the openness of history, its potential for bifurcations, that is used by a 'virtuous' ruler to determine an outcome: the specific organization of a world. ${ }^{48}$

47 Jacques Derrida, 'A Certain Impossible Possibility of Saying the Event.' Participants in a recent debate, like Alain Badiou and Slavoj Žižek, tend to mix up the notions of moment and event as well. 'Moment' hardly ever becomes a separate topic of concern. See Alain Badiou, Etre et l'Événement, and Slavoj Žižek, Event.

48 J.G.A. Pocock defined the moment differently in The Machiavellian Moment. I am indebted to Louis Althusser's Machiavelli and $U s$, as when he contends that 'Machiavelli is the first theorist of the conjuncture', or the first 'to think in the conjuncture: that is to say in its concept of an aleatory, singular case' (18). 
My dealing with the moment is much indebted to Henri Bergson, who by means of his idea of multiplicity 'un-mixed' the notions of time and space to considered the moment separately from event. He connected the notion of moment to the indivisible realization of time, and that of event to a time cut up in order to take a hold of it conceptually. ${ }^{49}$ The first kind of knowledge he defined as intuitive, the second kind as conceptual. The two work aesthetically differently in that the event extends over time as part of a chronology, and the moment works instantaneously as component of a durée. The event fascinates, the moment propels or 'hits'; the one organizes space, the other intensifies time.

The notions of moment and event are intrinsically related to what will be the theme of my next section: the distinction between dramatization and theatricality.

\subsection{Two executions: theatricality and dramatization}

The republican baroque can be marked by a moment of ascendance and a moment of decline. In presenting these two moments, I do not mean to say that there are no Dutch republican baroque works before the opening moment and after the closing one. Yet, these dates mark the comet-like appearance and disappearance of this specific form of baroque, of which the ascendant moment is 13 May 1619: the date of the execution of Johan van Oldenbarnevelt, the secretary of the States of Holland and, in practice, the political leader of the Republic. ${ }^{50}$ This was a traumatic event fabricated by stadholder Maurits. A study by historian A. Th. van Deursen on what occurred between the two major actors was tellingly titled Maurits of Nassau: the winner who failed..$^{11}$ The book's thesis is that, despite Maurits' position as perhaps Europe's greatest military leader, he ultimately failed in his political dealings with Oldenbarnevelt. According to Van Deursen, the basis of the political conflict had not been that Maurits had sided, in the religious conflict that dominated the Republic, with the Counter-Remonstrants and Oldenbarnevelt with the Arminians. Rather, both had a fundamental difference of opinion about the nature of the relation between state and religion.

49 Henri Bergson, The Creative Mind.

$5^{0}$ On the atmosphere in the Republic and the decisive turn of events embodied in the execution, see Freya Sierhuis, The Literature of the Arminian Controversy. For a short summary of the growing tensions between Maurits and Oldenbarnevelt, see René van Stipriaan, Lofder botheid, pp. 79-94.

51 A.Th. van Deursen, Maurits van Nassau. De winnaar die faalde. 
Oldenbarnevelt considered the state a political power that could guarantee different forms of religion peaceful existence with one another. Maurits considered orthodox Calvinism the one church that could guarantee the safety and coherence of the state. In this context Oldenbarnevelt became the victim. Yet, despite the removal of his major political opponent, Maurits did not emerge as the winner. Why not?

The Dutch republican baroque enters the scene by means of an artificial, theatrically staged event with real consequences that found its closure in the dramatic moment of Oldenbarnevelt's beheading. This event proved to be traumatic, but also propelled forces that wanted to open up the very world that seemed to have been foreclosed with Oldenbarnevelt's death. These republican forces would prove to be successful for about five decades. Then, the Dutch republican baroque witnessed its moment of decline, which can be defined as an execution of sorts as well: 20 August 1672. As if in reverse, it concerns a craftily prepared dramatic moment that would become frozen as a horrifying or joyous theatrical event. What happened on that day was reconstructed in detail by Ronald Prud'homme van Reine, who defines the events as 'the blackest page of the Golden Age': the public lynching of the brothers De Witt, a lynching produced by the forces surrounding stadholder William III (see chapter 3)..$^{2}$

If in the above I distinguished between moment and event and this can now be expanded by defining their dramatic and theatrical quality, how, in what follows, will I be using these terms, both historically and conceptually?

The term drama will be used to indicate a historically specific artistic genre, one that became more and more dominant in the course of the seventeenth century. Medieval forms of theater hardly knew any form of drama. It reemerged first in so-called school dramas and then entered the public world with the coming into being of modern theaters in the late sixteenth and seventeenth century. ${ }^{53}$ Especially seventeenth century drama was an aesthetic genre that played a straightforward political role in society at times but also reflected, principally, on the nature of the political. ${ }^{54} \mathrm{With}$ dramatic I will indicate a dramatic aspect of something. Paintings can have dramatic aspects, just as public processes or executions can. A typically dramatic aspect is the coming together of actors in an intensified, conflict driven situation that involves a bifurcation, one possibility becoming real

52 On this see Ronald Prud'homme van Reine, Moordenaars van Jan de Witt.

53 For this see Erika Fischer-Lichte, History of European Drama and Theatre.

54 This was one of the major contentions in Walter Benjamin, The Origin of German Tragic Drama. 
and another one foreclosing or splitting off to another real. The day the brothers De Witt were attacked and killed, for instance, was full of such dramatic moments in which things could have gone one way or another. Finally dramatization indicates the action due to which a new scene comes to life on some sort of (politico-aesthetic) plane and a world is intensified or opened up. It may be clear that dramatization is not a seventeenth century concept. I take it from Gilles Deleuze and translate it from its philosophical context to the field of cultural analysis. When René van Stipriaan calls the struggle between Maurits and Oldenbarnevelt 'a drama' that may have started before 1600 , he may be thinking about the two as characters in a drama. ${ }^{55}$ Yet what he describes is also a process of dramatization, propelled by actors who are acting time and again in unpredictable circumstances, their actions moving towards one world or another.

I am well aware that the term drama has been used rather differently in theater studies, where it is understood in relation to Aristotelian plot, as the organization of actions and events that leads to the expected end. This was precisely what Bertolt Brecht had against the term 'drama'. The plot tended to sweep the audience along all too smoothly, neutralizing their power to be active. ${ }^{56}$ Still, plot is a narrative construct: a mode of skillfully organizing actions and events with a purposeful outcome. It is not a matter of acting-in-the-moment. Yet, drama is derived from Greek dran, which means acting in the sense of doing. I take this etymology seriously: the dramatic is a matter of doing, of stepping into the action, of starting to act, as a result of which something new can come into being. As such, it is distinct from the theatrical, the etymology of which goes back to theasthai, 'to behold', an issue of showing and seeing, as a result of which something can be reflected on or reconsidered.

The term theater will be used to indicate a historically specific institution, or even a concrete theater. For instance, the theater that was being built in Amsterdam in the 1630 s was welcomed by Joost van den Vondel, who praised its architect Jacob van Campen as follows: 'We imitate majestical Rome on a smaller scale / now that Kampen is busy building it'. ${ }^{57}$ Indeed, a

55 René van Stipriaan, Lof der botheid, p. 80.

56 The text appeared as notes accompanying the publication of the opera Aufstieg und Fall der Stadt Mahagonny, in 1927. See Bertolt Brecht, Brecht on Theater. See also Walter Benjamin, 'What is Epic Theater?' in Understanding Brecht, p. 2. As Hans-Thiess Lehmann argued, Brecht's reading of Aristotle was more determined by Aristotle's Nachwuchs than by the actual content of his analysis. See Hans-Thies Lehman, Postdramatic Theater.

57 In the original: 'Wij bootsen 't groote Rome na in 't kleen / Nu Kampen bezig is met bouwen'; Joost van den Vondel, 'Op den nieuwen Schouwburgh. Aen den Raedsheer Nikolaes van Kampen'. 
few years earlier, an important group of humanists had started thinking of a public 'gathering place' (verzamelplaats). It was to be built 'according to the way of the old Roman theaters' as a public gathering place, which made it institutionally speaking radically different from the theaters constructed in the context of the Royal courts..$^{8}$ Both spaces could be called theatrical, a term that I will use to mark the theatrical aspect of something. A typical theatrical aspect would be a set of layers: the layer of how something appears and the layer of what lies behind it. For instance, the execution of Oldenbarnevelt appeared theatrically as a public and legal execution but, on another level, was read by many as the brutal elimination of a political competitor. In this context the term theatricality becomes meaningful as well. Theatricality indicates the action due to which a scene comes to life on some sort of (aesthetic-political) stage. Such scenes and stages were principally different in royal and public contexts.

In my definition of theatricality I am building forth on the distinction between the theatrical and theatricality that was developed by Tracy Davis. ${ }^{59}$ For Davis, the theatrical concerns all kinds of elements and manifestations of theater. Theatricality concerns the distancing, in a sense alienating, social dynamic between audience and any kind of performance that comes into being when an audience defines itself as self-aware. Consequently, the theatrical concerns a concrete stage of some sort, while theatricality concerns the situation in which something is perceived as being staged. Josette Féral described this coming into being of the theatrical situation technically as the result of 'a performer's reallocation of the quotidian space that he occupies' or 'a spectator's gaze framing a quotidian space that he does not occupy'. Simply put, a performing actor redefines daily space as theatrical stage by means of his performance, and someone who considers something as a theatrical performance redefines himself as a viewer watching some sort of stage within a certain frame. The result is the production of an outside and an inside that changes reality. ${ }^{60}$ Theatricality aimes to

See Joost van den Vondel, Gysbreght van Aemstel. (ed. Mieke B. Smits-Veldt), 1994, p. 34 . $5^{8}$ On this, see B. Albach, 'De schouwburg van Jacob van Campen'. The quote, 'naar de wijze der oude Roomse schouwplaatsen' has its source in O. Dapper, Historische Beschrijvingh der Stadt Amsterdam.

59 In their introduction to Theatricality, editors Tracy C. Davis and Thomas Postlewait argue against a conceptualization of theatricality that becomes overarching and ends up being meaningless. Tracy Davis is specific in 'Theatricality and Civil Society.'

60 As Féral contends: 'theatricality as alterity emerges through a cleft in quotidian space' and thus has the power to situate the historical self in relation to a theatrical 'other'; Josette Féral, 'Theatricality: The Specificity of Theatrical Language', p. 97-98. 
take the theatrical out of the domain of the theater proper and translates it to the way in which people find themselves actors in, and viewers of, a framed world. As such it is a matter of self-awareness and of self-reflection produced by means of a theatrical mirror.

Dramatically speaking, actors are acting on a plane that is defined by an awareness that something decisive is happening. This involves intensification. All those involved are actors and viewers at the same time, experiencing themselves in relation to their charged acting, whether this acting is serious or ludic. The dramatic is separated from the quotidian not in terms of space, then, but in terms of time, or rather intensity, which is time condensed by the sense and awareness that a potential bifurcation of worlds is at stake. ${ }^{61}$ I take my cue here from Gilles Deleuze who defined the actualization of something new in philosophical thinking - bringing concepts to life'-as dramatization..$^{62}$ I will translate his term, aesthetically and politically, to a historical world of praxis. ${ }^{63}$ For Deleuze, dramatization implied that a philosophical problem was not solved through concepts but the very problem was dramatized by, or became apparent in, newly actualized concepts. This is why I suggested previously and by analogy that the Dutch Republic was not the solution to a political problem, but rather posed the problem of the political. In that context, my question is: how can we use the concept of dramatization to understand this republican historical situation in which the problem of the political was actualized?

Although the concepts of theatricality and dramatization can (and should) be distinguished, the border between them is porous; both will almost always appear entangled, and not just in the Republican baroque. For instance, Louis Althusser's ideas on political theater as Darstellung or presentation implied that the roles of author, actor, and spectator coincide. Althusser defined this theater as a space and situation which is:

61 This mode of acting was described in terms of absorption by Leonard Huizinga and Michael Fried, and such absorption can be read as a matter of intensity in its concentration on the here-and-now.

62 One text in which Deleuze talked about this explicitly is 'The method of dramatization'. His ideas on dramatization were developed in his studies on the thinking of Hume, Bergson, Kant and Nietzsche, but most explicitly so in Nietzsche and Philosophy and Difference and Repetition. 63 As for a translation of the concept to the political-aesthetic domains, see Iain MacKenzie and Robert Porter, Dramatizing the Political; worked out in brief in 'Dramatization as method in political theory'. In the latter their question was summarized as: 'what kind of critical purchase does the method of dramatization actually give us in trying to determine the conditions of political concepts?', p. 484 . 
...simultaneously its own stage, its own script, its own actors, and whose spectators can, on occasion, be spectators only because they are first of all forced to be its actors, caught by the constraints of a script and parts whose authors they cannot be, since it is in essence an authorless theater. ${ }^{64}$

Although Althusser is talking about theater here, the term 'authorless' suggests that a dramatic situation is at stake, in which nobody has control of what is to be said and done and in which roles of actors and spectators oscillate. As soon as a form of control is in play, and the division between actors and spectators becomes sharp, a situation tends to become theatrical.

Especially the second execution, of the brothers De Witt, is a paradigmatic case in point. Major conspirators, 'authors' of what was about to happen, had come to The Hague to watch what would enfold. This was the theatrical part. There were people scripting an event that others were about to act out. This did not mean, however, that everything which happened was scripted. All the actors, all the props were there, yes, but the question was which dramatic moment was going to be decisive; how actors and props would be thrown dramatically into a scene or would produce a new situation. In other words, the question was what the mise-en-scène would become. Nobody, as far as we know, had envisioned that the bodies of the brothers De Witt would be torn apart and that parts of their bodies would be sold on the street. Alternately, the mob could even have been denied this opportunity. The brothers could have escaped, forcing people to go home or to the pub to drink away their disappointment.

Meanwhile, everything that happened on that day embodied the problem of the political as it was actualized in the Republic. William III, clearly the winner of the day, would later become king of England. Yet, he would never be, or theatrically appear as, king of the northern Low Countries. For this they remained too republican, and William III was well aware of it.

As this example may illustrate, both theatricality and dramatization relate to politics and the political. Hannah Arendt defined human beings as political by the ways in which their actions appear to the public eye, that is: theatrically. In her terms: 'Nobody knows whom he reveals when he discloses himself in deed and word. ${ }^{65}$ Arendt considered politics as a space of appearance: that is, where 'fragile' forms of speech and action form the

64 See Louis Althusser, 'The Object of Capital', p. 193; see also Louis Althusser, 'On Brecht and Marx'.

65 Hannah Arendt, The Human Condition, p. 180. 
pivot of a public debate, deciding the course to be taken, politically ${ }^{66} \mathrm{We}$ see the two terms entangled again here. The way in which political actors appear is a matter of theatricality, but the fragility that Arendt speaks of implies drama. If there is one thing that characterizes the political, it is this dramatic fragility, which suggests the intensity that resides at the core of dramatization. It is due to this intensity that actors witness the unexpected opening up of another possibility, of another course, and by implication another world.

The political relates, indeed, to the opening up of a world, or to the new, what Arendt defined as natality. Such a world is incompatible with others and this involves principle struggle. ${ }^{67}$ The Dutch Republic was a distinct political entity that came to life aesthetically and politically by assimilating poetic art and reality in one living process ${ }^{68}$ This is not to say that it was a thing of beauty. As the cases of Oldenbarnevelt's execution and the lynching of the brothers De Witt prove, the Republic embodied struggle. This involved dramatic moments in which one possibility or more possibilities were foreclosed, and one became actualized and real. In both cases, the possibilities that had been foreclosed, or the one possibility that was actualized, had to be reflected upon theatrically. Indeed, both executions led not only to plays that served to reflect on what had happened, but also to an explosion of texts and images serving the same purpose of theatrical reflection.

\subsection{Republican baroque and slavery}

Earlier I stated: 'All in all, the Republic, in becoming active, stumbled into a world that it helped to make at the same time. It fused an awareness that the world could be made artificially with an awareness that the contingency of history was not fortunate or accidental, but, politically speaking, foundational. Its very contingency entailed freedom.' One vexing question immediately poses itself. How did all this relate to slavery and the

66 On this see Richard Halpern, 'Theater and Democratic Thought: Arendt to Rancière', p. 548.

67 I am following the distinction between politics and the political, here, made by Chantal Mouffe in On the Political.

68 I take my phrasing, here, from the sociologist Georg Simmel, who defined drama in modernity as a form of acting 'which assimilates both the poetic art and reality into one living process, instead of being composed of these elements in a mechanical fashion. See Georg Simmel, The Conflict in Modern Culture and Other Essays, p. 99. Quoted in Marvin Carlson, Theories of the Theater, p. 29. 
slave trade? Well, the development of the slave trade in the period under consideration was a political crime, and considered as such by some in the Republic. It implied a loss of sensibility that, consequently, had an effect of de-politicization. In other words, slavery implied a refusal to actualize a new world and a choice to stick to the power structures of an already established one. With slavery, the Republic went against its most basic principle and gave in to terror. To be sure, slaves were brought to a world that was defined as 'new' from a European perspective, but to the Africans who were being transported in 'the belly of the boat' it was framed by pre-existing power structures in which they remained caught. ${ }^{69}$

Ironically, the Dutch Republic had been established as a necessary move to escape a situation of tyranny and slavery. In the first great text against the use and existence of torture, Johannes Grevius's Tribunal reformatum (1624), torture was related to this distinctly political model of tyranny. Grevius' argument corresponded with Jean Bodin's in the first of his six-volume study on the state and sovereignty: Six Books of the Commonwealth, from $1576 .^{7^{\circ}}$ Bodin argued that slavery had led to cruelties that were unacceptable. However, whereas Bodin carefully distinguished despotic rule from paternal rule in order to propagate the patriarchal rule of the sovereign, Grevius criticized the conflation of torture and slavery as the intrinsic effect of the conflation of Roman dominium with political rule. ${ }^{71}$ The conceptualization of politics in relation to a dominium, a 'house' with a master or more specifically a father, was one of the hottest points of debate in the seventeenth century.

The history of slavery per se connected from the start with political slavery, as when the free subjects of a political entity were not free at all but subjected to the rule and will of a master. ${ }^{72}$ Mary Nyquist traces how this 'Greco-Roman polarity between free and enslaved' is at the basis of massive discussions in Europe in the sixteenth and especially the seventeenth century. By then, the issue had become even more complicated with the arrival of trans-Atlantic slave trade..$^{73}$ In this context, it is much more than historical irony —indeed, it is a crime in the sense of a misdeed — that the

69 With 'the belly of the boat' I refer to Édouard Glissant, Poetics of the Relation, p. 6.

70 Jean Bodin, The Six Bookes of a Commonweal.

71 The term dominium, not Roman in itself, came to life in the medieval renaissance of Roman law.

72 On this see, for instance, Quentin Skinner, 'John Milton and the politics of slavery', in his Visions of Politics, pp. 286-307, or 'Rethinking Political Liberty'. Interestingly, in both cases, and throughout the work of Skinner, the issue of torture and its connection to the logic of the household as a paradigmatic political model is not dealt with.

73 Mary Nyquist, Arbitrary Rule, p. 72. 
Dutch Republic would become engaged in slave trade in the course of the century. At the beginning of the seventeenth century, slave trade was out of the question to many. Later, principled arguments were brought forward against it. In practice it would start to grow from the 1640 s onward, after the United West Indian Company, the wIC, had conquered parts of Brazil. The development of the slave trade was a decisive moment of closure, here, of the Dutch baroque as republican. As has recently become clear, moreover, the slave trade not only grew into one of the great historical wounds in the Atlantic but was equally big business in Asia which has led literary historian Reggie Baay to turn the colonial eulogy of 'Something grand was established there' into the lament of 'Something horrible was established there'. ${ }^{74}$

Though the history of the slave trades has been described, it is still a struggle to adequately represent it. It would demand another book to capture its characteristics, which implies another kind of baroque, distinct from both the Southern European papal and royal one and the Dutch republican one..$^{75}$ The study that follows is about a republican baroque that was only made possible by the principal rejection of slavery. As will become clear, this rejection was not, and could not be a straightforward one due to the ambiguous status of the Republic as both a republic and a quasi-empire. This ambiguity is central to the next chapter.

74 Reggie Baay, Daar werd wat gruwelijks verricht.

75 On this see Robin Blackburn, The Making of New World Slavery, and Lois Parkinson Zamora and Monika Kaup, Baroque New Worlds. 
This content downloaded from 132.229.156.144 on Tue, 05 Feb 2019 10:42:50 UTC All use subject to https://about.jstor.org/terms 


\section{The dramatic potential in history: Rome and the Republic - Grevius, Vondel, Knüpfer, and Job}

\subsection{Two incompatible political models: transfer or disruption?}

The show-process in which Johan van Oldenbarnevelt, the Grand-Pensionary of the States of Holland and true political leader of the Republic, had been found guilty led to his execution on May 13 of the year 1619. Tellingly, this was only four days after the international Synod of Dordt had had its final meeting. In this Synod the orthodox Counter-Remonstrant parties, supported by stadholder Maurits, had gotten the upper hand. After Oldenbarnevelt's removal they had every opportunity to clear the Republic of what they considered to be religiously impure. Many people were intimidated, harassed, arrested, blackmailed, or banned, and a considerable number were threatened with the rack. Some were tortured severely; others were executed or imprisoned and found themselves in circumstances that would surely lead to their death. For instance, because of his Remonstrant or Arminian preaching in the Republic, one Johannes Grevius had earned a lifelong sentence, to be served in the Amsterdam prison. Given the circumstances and with his constitution he would have survived no more than a few years of imprisonment at best. Moreover, before his imprisonment Grevius had been tortured severely. It led him to write one of Europe's first elaborate treatises against the use of torture, Tribunal reformatum, in $1624 .{ }^{76} \mathrm{He}$ could not have written it, however, had he not been freed.

In mid-August 1621 one of the officially banned ministers, Dominicus Sapma, tried to free two of his colleagues: the aforementioned Grevius and Samuel de Prince. Both were imprisoned in the Amsterdam tuchthuis, the house of correction, punishment, or discipline. Sapma's first attempt failed. Just a little later, and by mere coincidence, Sapma was recognized

76 Johannes Grevius, Tribunal reformatum in quo sanioris et tutiorisjustitiae viajudici christiano in processu criminali commonstratur, reiecta et fugata tortura. The work was originally published in 1624, but I will be quoting from the 1737 edition with the same title. Early studies on Grevius are Johannes Janssen, History of the German People After the Close of the Middle Ages, and Alec Mellor, Un chef d'oeuvre méconnu: les 'tribunal reformatum' de Grevius (1624). On Grevius' case also see: Jan Pieter de Bie and Jakob Loosjes, Biographisch woordenboek van protestantsche godgeleerden in Nederland. Deel 3 . 
while walking in the streets of Amsterdam and immediately imprisoned himself. Yet, he managed to escape disguised in the clothes of his wife, Grietje Ulbes, who had come to visit him and now had to stay in prison. This allowed Sapma to continue his attempts to free his friends-helped, this time, by companions, copied keys, and ladders. ${ }^{77} \mathrm{~A}$ third attempt was successful, and a little later his wife was released without much ado. There is a contemporaneous song about the escape, called 'On the salvation of Samuel de Prince and Johannes Grevius'. ${ }^{8}$ The song not only rejoices in the escape of both men from the Amsterdam prison, it considers their escape an intervention from God, who, from now on, will teach the CounterRemonstrants to no longer 'tyrannize' the country. ${ }^{79}$

After his escape from prison, Grevius would flee to Germany, where he would write his treatise against torture. The text was revolutionary because, among other things, it related the unacceptability of torture not to its false purpose in the context of witchcraft, as in the previous century, but to a form of political rule. ${ }^{80}$ Grevius had been denied access to all sorts of literature in prison. He was allowed, however, to study law, especially Roman law, and this had brought him to the heart of a matter that was both personally and politically vexing. It was personal because he had been through torture and political because torture, to him, was the inevitable outcome of a distinct way of organizing the political domain, like a household, or dominium. ${ }^{81}$ The

77 More on Sapma and his process can be found in J.G. van Dillen, 'Documenten betreffende de politieke en kerkelijke twisten te Amsterdam (1614-1630)'. For a detailed and at times hilarious report of the various escapes, see Jan Wagenaar, Amsterdam, in zijne opkomst, aanwas, geschiedenissen, voorregten, koophandel, [etc.], pp. 478-80. Aside from the two Remonstrant ministers, a third man escaped, a Jesuit from Brussels, as well as two others of yet other religious convictions - all from groups who had helped in the escape.

78 In the original: 'Op de verlossinge van Samuel de Prince, ende Johannes Grevius'; see also A.Th. van Deursen, Bavianen en Slijkgeuzen, pp. 320-321.

79 Camerata Trajectina, Bavianen en Slijkgeuzen: Liederen van Remonstranten en ContraRemonstranten uit het begin van de 17de eeuw (Globe 6031, 1995); see the site of 'Nederlandse liederenbank: http:/www.liederenbank.nl/bronpresentatie.php?zoek=10844\&lan=nl (visited March 2017). In the original the phrase is: 'het tiranniseeren sal Hy u verleeren.... The album is called Bavianen en Slijkgeuzen in an explicit reference to the famous study, from 1974, on the violent conflict in daily life between Remonstrants and Counter-Remonstrants by A.Th. van Deursen. Counter-Remonstrants were mocked as 'slijkgeuzen' ('mudbeggars') following 1612, when their meetings had been prohibited in Rotterdam and they were forced to move outside of town, to places that could be reached only through muddy pathways. Later 'bavianen' or 'baboons' became a popular nickname for Arminians because the two words sound similar in Dutch, and monkeys had been considered devilish since the Middle Ages.

80 On this, see Helen Parish, ed., Superstition and Magic in Early Modern Europe, especially Brian P. Levack's chapter 'The Decline and End of Witchcraft Prosecutions', pp. 336-72.

81 Grevius, Tribunal, Lib. 1, caput II, par. VI, VII, VIII, pp. 23-29. 
two combined, torture and slavery, should be rejected in principle since Christians, being free, could not tolerate torture any more than slavery, or so Grevius argued. This brought in more than a few ambiguities, however. Studying Roman law had brought Grevius to respect it, but at the same time the coincidence of dominium, slavery, and torture formed part and parcel of the Roman legacy also in terms of Roman law.

Such ambiguities around the Roman paradigm were not idiosyncratic. They defined more general attitudes towards the Roman paradigm in the Dutch Republic, which were both similar to and different from the ones in England. As Quentin Skinner has argued, the issue of slavery was mainly dealt with in the context of authors propagating the republican freedom of citizens. At the same time, however, especially in the case of Thomas Hobbes, the notions of slave and slavery would become softened into those of servant and servitude, and become a paradigm for political obedience, or subjection, the price to be paid for a sovereign's safeguard against disorder. ${ }^{82}$ In this context Skinner contended that 'one of the deepest divisions in modern European thought' was the division between 'the neo-Roman theory of freedom and self-government, [...] and the modern theory of the state as the bearer of uncontrollable sovereignty'. ${ }^{83}$ Yet, he could only state this while silently accepting the fact that the Roman propagators of republican freedom were masters of households themselves, with slaves. Moreover, he could only state this by ignoring the fact that Thomas Hobbes was an equally avid reader of Roman texts, which allowed him to postulate the 'sameness of dominion and subjection'. ${ }^{84}$

The conceptual conflation of political power with dominium was as 'neo-Roman', then, as the republican renaissance. In terms of its political and ethical configuration the Roman heritage was ambiguous per se. It mixed the tradition of the republican freedom of citizens with the tradition of slavery and imperial mastery by Caesarean rulers, which was translated to the rule of popes who considered themselves, legally, as the inheritors of imperial rule. This ambiguity specifically bothered the Dutch Republic, with its quasi-imperial, colonial expansion. ${ }^{85}$ Much like those opposing the so-called tyrannical rule of the sovereign in England, the Republic and Amsterdam considered themselves to be the inheritors of Rome's republican

\footnotetext{
82 On the two different ways of dealing with the issues of slavery and freedom on the one hand and servitude and subjection on the other, see Quentin Skinner, 'On the Liberty of the Ancients and the Moderns'.

83 Quentin Skinner, Visions of Politics, p. 9.

84 Mary Nyquist, Arbitrary Rule, p. 324.

85 On this see Arthur Weststeijn, 'Republican Empire'.
} 
liberties and virtues. However, the glory of Rome built up from scratch also provided the paradigm for the Republic's own unexpectedly glorious and quasi-imperial status. Rome's paradigm of imperial rule was impressive. Yet it also turned subjects into, politically speaking, un-free subjects, or 'slaves', and this proved more difficult to swallow, or had to be downright rejected. The political issue, moreover, easily shifted to a religious one, since Rome had also become shorthand for the Catholic Church, which was regarded by many in the Dutch Republic as a tyrannical power in itself. Yet, it was considered by others, such as Vondel and Grotius, as the only paradigm that could save Europe from sectarian strife and ruin.

At stake, then, in this chapter is the way in which the Dutch Republic staged itself in relation to, specifically, Roman history in the double sense of the word: classical Rome and Catholic Rome. To some the Republic should be positioned in the context of the translatio imperii, the way in which history could be periodized on the basis of the transfer of power from one empire to another ${ }^{86}$ Whereas churchfather Jerome had originally sketched the transfer of power from the Babylonian, to the Persian, to the Macedonian and finally the Roman empire, the medieval question had become who would be the next imperial power, with in the sixteenth and seventeenth century the Habsburg empire, of course, as a first candidate. Yet, the small Republic had beaten that vast empire, and Amsterdam now seemed to rule the waves. The translato imperii is clearly a narrative construct and, in the Christian worldview, one of allegorical prefiguration. With all this in mind, the questions at stake were: was the republican baroque a response to those who wanted to theatrically stage and legitimate a so-called imperial transfer, or did it emphasize the dramatic and disruptive powers of a free Republic?

\subsection{Allegory tied into a knot: history's continuity dramatically disrupted}

In chapter 1 I explained the actualization, in 1638, of the new Amsterdam theater, a building that referred explicitly back to republican Rome. It was surely not the only one doing so. The new Amsterdam city hall, opened seventeen years later, was an even more iconic example. With this building, Amsterdam was looking not just for historical comparisons but also for historical paradigms that could help define its role in history. The plan for

On this see Helmer Helmers, 'The Politics of Mobility'. 
this 'Palace of the Republic' drew from biblically inspired architecture, but to the seventeenth-century eye this was allegorically translated via Rome. ${ }^{87}$ In a praise poem written for the opening of the new city hall, but also in order to defend the costly building against its many critics, Vondel was explicit about the paradigmatic relation between Rome and Amsterdam, as, for instance, in the following passage:

The king of the city, the crown of whom would tempt violence Chose the Tarpeius mountain alone, out of seven, Nearby the stream of the Tiber, and its whirling, Where the eagle and chair of the battle-ready people,

5 Could be planted as on the free citadel, of the commonwealth, That would turn against all the powers of the world.

Thus the Capitol arose, on this stony rock, Covered by Romulus with a thatched roof, nigh in gold Like a golden mountain, that with the setting 10 And rising of the sun, would outshine the sun in pride, An honor, for which the mountain thanks Numa, As long as the Roman domain, that will never perish, nor collapse, Will in his own way last, and will stay in this world forever. ${ }^{88}$

Just as Rome was built near the Tiber, Amsterdam was built near the waters of the whirling river 't Y, and just as Rome had started out with 'thatched roof', so Amsterdam had its humble beginnings. Yet, both now had roofs of gold that would shine forever, the one's radiance facilitating that of the other, insinuating that the empire of Rome had now been allegorically transferred to that of Amsterdam. It all followed the logic of the medieval concept of the translatio imperii, according to which history followed the lineage of successive empires.

87 On the biblical origins of architecture and the allegorical translation of the city hall via Rome, see Pieter Vlaardingebroek, De geschiedenis van het stadhuis van Amsterdam. On the city hall as a baroque building, see Katherine Fremantle, The Baroque Town Hall of Amsterdam. 88 Vondel, 'Inwydinge' ll. 145-157, WB V, pp. 865-866. In the original: 'De Koning van de Stadt, wiens kruin 't gewelt zou tergen / Verkoos Tarpeius bergh alleen, uit zeven bergen, / Omtrent den Tiberstroom, en zijne waterkolck, / Om daer den adelaer en stoel van 't strijtbre volck, / Als op den vryburgh van 't Gemeene best, te planten, / Dat tegens al de maght der weerelt zich zou kanten. / Dus rees het Kapitool, op dezen steenen bult, / Van Romulus met riet gedeckt, en na vergult / Gelijck een gouden bergh, om, in het onderdaelen En opstaen van de zon, de zon ten trots te praelen / Een eer, waer voor de bergh den vader Numa danckt, / Zoo lang 't Romainsch gebiet, dat nimmer zackt, noch schranckt, / Maer op zijn wyze duurt, de weerelt zal verduuren.' 
That said, the legacy of Rome that Vondel used in his poem allowed diverging interpretations. Classical Rome and the Roman Catholic Church could, ambiguously, be mentioned in one breath, as happens in the last line of the cited passage: the political legacy of Rome translates a historically anchored power to a spiritual power that will last eternally in the shape of the Roman Catholic Church - at least in the eyes of Vondel. A less obvious ambiguity, but one at play nevertheless, relates to Rome's republican origins. These origins allow a parallel to unfold more appropriately between Rome and a commonwealth of free citizens but far less appropriately between Rome and an imperial power. At the same time, however, it is the imperial power to rule the world that makes Rome comparable with Amsterdam. The ambiguities in play and the specific form of allegory that they produce, by means of which two historical periods are anachronistically conflated in the last two lines of the poem: it is all distinctly baroque, but with a twist. ${ }^{89}$

When the city hall was completed in 1655 the Republic was in its first so-called stadholderless period (lasting from $165^{\circ}$ to 1672 ). Only a decade earlier, with Frederick Henry as the major political ruler, the Dutch politico-aesthetic dynamic had been comparable to other European, royally inspired forms of baroque (although this had been complicated by the fact that Frederick Henry was not a real king, of course). In the 165os and 6os, in a non-royal context, the Dutch Republic found itself a world power without a real political center. It was not a straightforward republic, but edged closer to a commonwealth or confederation, consisting of free and independent states with free people in free cities, and with Amsterdam as a city-state that formed the hub both of this network of cities and of world trade. In this context, the Rome allegory was useful for underpinning the authority of republican forms of statehood, because these forms resembled Rome's republicanism and linked Amsterdam's position to that of a former world power. Yet, it was a troubling allegory nonetheless, especially in its connection to the Roman Catholic Church, which for many Protestants was equated with tyranny. As for tyranny, yet another historical allegory depicted Rome as the archenemy of the Dutch. This involved the so-called Batavian myth, activated by, among others, Hugo Grotius, P.C. Hooft, and Vondel, according to whom the free Dutch Republic had its origins in a

89 For this ambiguity also see Arthur Weststeijn, "The Power of 'Pliant Stuff". Focusing on the radical republican brothers and political theorists Johan and Pieter de la Court, Weststeijn shows how Vondel's fables in Vorsteliicke warande der dieren (Princely Garden of Animals, 1617) helped the brothers to argue that monarchy in the Dutch Republic would inevitably come down to tyranny. 
revolt of the Batavian people against Rome's imperial and perverted powers some 1600 years earlier. ${ }^{90}$

The complexities revolving around the Rome-Amsterdam parallel were captured nicely, albeit paradoxically, in the deliberately destroyed manuscript of a tragic play. In a letter to Hugo Grotius dated 9 September 1639 (to which we will return in chapter 4), Joost van den Vondel wrote about the situation he was in and mentioned some of the manuscripts he was sending along or was intending to send:

I have been falling back on tragedies and have an unprinted one about Silius and Messalina, and one half finished about Saul's seven sons, who were hanged near Gabaon..$^{11}$

The 'half finished play about Saul's seven sons' was Gebroeders (Brethren), which was published in 1640, and which became one of Vondel's more successful biblical plays. The other play dealt with Roman material: Silius and Messalina. Some time after writing this letter, Silius and Messalina had apparently attracted enough funding, for it was being prepared for production. Vondel arranged a first reading of the text together with the actors. During the session, however, one of the actors asked for a clarification of the play's theme and plot.

Messalina, member of the vast Julio-Claudian house, who had already played a lively role in the entourage of emperor Caligula, has now become the beautiful, powerful, sexually active wife of emperor Claudius, who is physically handicapped and relatively old. She has an affair with the handsome and powerful young Roman senator Silius. When Claudius is away for business she holds a party at which her marriage to Silius, either seriously or mockingly, is arranged. The emperor returns just in time and has her killed, along with Silius and all those present at the party, condemning Messalina to be entirely forgotten, the so-called damnatio memoriae.

90 Primary texts, but certainly not the only ones, were Grotius's De antiquitate reipublicae Batavicae from 1610, the play Baeto by P.C. Hooft from 1617 and, much later, Vondel's Batavische gebroeders (Batavian Brethren) from 1662. See Hugo Grotius, The Antiquity of the Batavian Republic; P.C. Hooft, Baeto; Joost van den Vondel, Batavische gebroeders ofte onderdruckte vryheit, in WBIX, pp. 898-971.

91 Hugo Grotius, Briefwisseling van Hugo Grotius. Deel 1o, p. 582. In the original: 'Ick ben aen de treurspelen vervallen en heb noch éen ongedruckt leggen van Silius en Messaline, en éen ten halven voldaen van Sauls zeven zonen, die bij die van Gabaon opgehangen werden.' See $<$ www.grotius.huygens.knaw.nl>. See also: Geeraardt Brandt, Het leven van Joost van den Vondel, pp. $37-38$. 
Sixteen centuries later Messalina had not been forgotten, clearly, and Vondel thought her story to be of interest. The actors asked: 'But how should we understand this?' Vondel's biographer Gerard Brandt describes, in a mixture of indirect and free indirect speech, how Vondel responded:

It was just as if a Prince, that he named, was a fool, and the Princess, while he had travelled someplace else, wanted to marry a counselor in the meantime..$^{2}$

Obviously, the Prince that Vondel alluded to was Frederick Henry, and the Princess therefore had to be the powerful Amalia van Solms. Although the comparison was met with laughter at first, the actors went to the pub afterwards and started to wonder whether the play was actually an allegory after all. Frederick was indeed frequently away and suffered from severe bouts of gout, and Amalia, well...93 Rumor spread. The regents of the orphanage who had paid for the play were alarmed and Vondel had to act quickly. He went back to the main actors and asked for the manuscripts, with the excuse that he wanted to change a few small things. He then destroyed the manuscripts, and thereby prevented illegal prints. Some parts would be recycled in other work.

Still, there may be much more than a trace of the play left. According to art historian Kees Schoemaker, one painting in the Rijksmuseum made by Nicolaus Knüpfer depicts a scene from the play. ${ }^{94}$ Formerly entitled Brothelscene, Schoemaker suggests, as a more fitting title, Theatrical Scene from Messalina and Gaius Silius Representing the Marriage (see figure 5). ${ }^{95}$ Schoemaker dates the painting between 1645 and 1655 . As he reads it, this is

92 Brandt, Het leven van Joost van den Vondel, pp. 42-43. In the original: "t is eveneens als of zoodaanig een Prins, - dien hy noemde, een nar was, en de Prinses, terwyl hy ergens naar toe was gereist, ondertusschen met een' Raadtsheer wilde trouwen.'

93 Brandt, Het leven van Joostvan den Vondel, p. 43: 'Om deeze onderrechting en gelykenis werdt in 't eerst gelacchen: maar daarna begosten eenige domme en losse Tooneelspeelers in hunne drinkgelaagen tegens elkanderen te zeggen, zou dit spel wel op dien Prins slaan? Misschien is Claudius die Prins, Messallina zyn Prinses en Silius zulk een Heer, dien zy, (onder andre Grooten, die de gemelde Prinses op de reize naar zeekre stadt verzelden) dwaasselyk uitkipten. Deeze praat liep eerst onder de speelers en werdt, zoo ongerymt als ze was, door zommigen, die den Poëet niet gunstig waaren, verder uitgestrooit, tot dat ze den Regenten van 't Weeshuis ter ooren quam.'

94 Kees Schoemaker, 'Het huwelijk van Messalina en Gaius Silius'.

95 Schoemakers's analysis proved to be succesful. The painting is now no longer called 'Brothelscene' but renamed 'Scene from the marriage between Messalina and Gaius Silius, possibly an episode from a play'. 
the scene where the party is at its climax, with the half-naked Messalina and Silius toasting, while some of the party guests are already looking outside, because someone appears to be rapidly approaching: Claudius.

Whereas a brothel scene could have been read iconographically as a moral warning, the painting would work radically differently if it depicted a scene from Vondel's Messalina and Silius, for then it might be allegorically referring to the stadholder and his wife, bringing up the delicate idea of bigamy. The way in which either the play or the painting worked allegorically would depend entirely, obviously, on how one thinks about allegory. In the Republic, in relation to this tragedy and in the context of the ambiguities concerning the Roman paradigm, allegory came to act dramatically, as if the cloth of history had been tied into a knot, allowing for Messalina to morph into Amalia, and the physically ill-disposed Claudius to morph into the physically equally ill-disposed Frederick Henry. ${ }^{96}$ As a result, the theatrical scene became dramatic in a double sense of the word. Firstly, it was part of a dramatic performance (whether in reality or in a manuscript). Secondly, it used two histories that were not meant to be looked at theatrically from a historical distance, but that were allegorically enfolded. As a result, they were operative simultaneously, in the present, fusing into one another.

The force of drama is not related to choice, here, but to a double meaning that, because it is folded into one image, produces a confusion that intensifies its political potential. Affectively and aesthetically this is not the Renaissance intertextual play defined by Daniel Arasse in Anachroniques and by Alexander Nagel and ChristopherS. Wood in Anachronic Renaissance (see chapter 1). ${ }^{97}$ To them, an anachronistic intertextual concatenation threatened the linearity of history, or the historicity of the work of art, which dissolved in the simultaneous or 'momentous' presence of two historically different times in one painting. In the baroque case, however, the danger does not lie in historically comparing Amalia to Messalina, or in letting the two coincide anachronistically. In the seventeenth-century context, this could simply be a matter of laughter and farce bordering on the obscene in a way that would have been familiar to many members of the Dutch elite. On the contrary, the danger lay in the dramatic potential of confusing Amalia with Messalina - and one should note how similar the names sound. The

96 On Frederick Henry in the last phase of his life, see J.J. Poelhekke, Frederik-Hendrik, Prins van Oranje, pp. 541-64. Poelhekke suggests that his last chapter should have been entitled 'Aftakeling' ('Decay'), p. 541.

97 Daniel Arasse, Anachroniques, Alexander Nagel and Christopher S. Wood, Anachronic Renaissance. 
confusing conflation of the two distinct characters, Amalia and Messalina, worked politically as a dramatic disruption that provoked questions: in what sense did the Dutch Republic resemble a perverted imperial power, in which the commonweal of free people would come to be ruled by something like a Julio-Claudian house? Would such a house rule in the manner of ancient Rome, ruling the state as its 'house' that is, with myriad perversities as a consequence?

Moreover, in the context of the Dutch Republic, the question was, after the Reformation, what kind of political household the Protestant church had become in its relation to the political house involved: the house of Nassau.

\subsection{Perverse powers, or how to make fun of the theater of torture}

Interviewed in 2009 on the occasion of the republication of three of his studies on the Golden Age, historian A. Th. van Deursen stated that the Netherlands even today remains 'rooted in seventeenth-century religion'. With respect to this, he expressed his concern about the fact that so few people could understand nowadays that to the seventeenth-century mind, belief was 'a public affair'. ${ }^{8}$ In the introduction to his study Bavianen en Slijkgeuzen Van Deursen had already stated that seventeenth-century Protestants did not speak much of the Protestant church. Instead they would speak:

...often about the Christian reformed religion. Not a coincidence, for sure; people did not want to see the existing domestic church organization as an enclosed national institute [...] but as the local materialization of a much bigger unity. ${ }^{99}$

Although there is much with which I can agree here, the danger is that Van Deursen mistakes the conceptual pair 'private' and 'public' for the political spaces of dominium and the res publica. The basic political and juridical

98 Geertje Dekkers, 'A.Th. van Deursen over "De Gouden Eeuw compleet"'.

99 A.Th. van Deursen, Bavianen en Slijkgeuzen, p. 1: In the original: 'Wie vertrouwd is met de vroege zeventiende-eeuwers, weet dat ze weinig spreken van de hervormde of de gereformeerde kerk, maar veel van de christelijke gereformeerde religie. Geen toeval zeker; men wilde de binnenslands bestaande kerkelijke organisatie niet zien als een besloten nationaal instituut, als een op zich zelf staande grootheid, maar als de locale verschijningsvorm van een veel groter geheel.' 
problem that plagued European politics was the superimposition of dominium over public affairs - an issue addressed by consecutive political thinkers such as Marsilius of Padua, Machiavelli, and much later Hannah Arendt. As early as the fourteenth-century Marsilius of Padua had argued, in his Defensor Pacis, that the Roman Catholic Church was an oikos, a house, which as such should not be allowed to lay claim to the public space of politics. Of course, laying such a claim was exactly what the Church did. For this very reason, Marsilius argued, it acted illegitimately. Likewise, the subject of debate in the seventeenth century was not whether belief was a public matter or not, it was whether any church could lay claim to public affairs from the position of an oikos or dominium, as was clearly the case with the Counter-Remonstrants. Although, for instance, stadholder Maurits' political maneuvering could be explained on the basis of his concern for the house of Nassau, this house was symbolically and metonymically also the embodiment of a state with one religion, one that for Maurits and Calvinists was the state's essential characteristic. Clearly Van Deursen did not consider this religion in terms of a 'household', and perhaps, spiritually speaking, it was not. Ideologically, however, and in the judicial and daily praxis of the Dutch Republic, it was. After the Synod of Dordt, the Counter-Remonstrant strategy was to get the household of church and state, considered to be one, unified in good order. To that aim torture was used, which need not come as a surprise, considering the intrinsic historical link between dominium and torture.

All things considered it might seem strange or slightly paradoxical that Grevius contends, in his treatise, that torture should be principally impossible for Christians. To be able to appeal to Christianity as the stronghold against torture, he refrained from basing his argument on the history of positive law that had influenced the development of European law since the revival of Roman law in the Middle Ages. Grevius first addressed some of the arguments that people might bring in to defend torture as being understandable and somehow reasonable, and then argued that a law that contradicted reason could be no law at all. Such reasonability could not be based on custom or posited law. Grevius used either divine law or natural law (like Grotius would) as the source of reason, in line also with what Aquinas had contended. The point was expressed succinctly by an 'or': 'naturae lege aut divino iure'. By bringing in divine law or natural law, Grevius held that there is no law above these. ${ }^{100}$ This appeal to natural law, moreover, implied ideas developed by the German political philosopher Johannes Althusius $\left(1575^{-1638)}\right.$ that each man is sovereign-free-by nature. In 
the Dutch context the work of Dirk Volkertsz. Coornhert (1522-1590) was pivotal, here, with his ideas on the freedom and autonomy of people. Yet the very notion of man as sovereign was a horror to Counter-Remonstrants, or to most royalists for that matter.

The tuchthuis where Grevius was imprisoned had been installed in 1596, and here as well the work of Coornhert should be mentioned, since he had explicitly come up with the idea of such modernized houses of correction. ${ }^{101}$ In general, the prisons that would be built throughout Europe in the centuries to come would contribute considerably to the disappearance of juridically supported forms of torture. ${ }^{102}$ Yet, while the establishment of the Amsterdam tuchthuis indeed offered an alternative means of punishment in the long run, during the hectic years after 1618 torture was used regularly. If it is the case, as Elisabeth Lissenberg suggested in her preface to a study on the Early Modern prison system in Europe by Pieter Spierenburg, that the way in which states dealt with criminals in the Republic was 'part of a larger social process in which justice from above grew stronger in connection with the increased power and confidence of the state authorities', one would have to be very clear what sort of a political 'above' this might be, and what kind of state authorities were so confident about their powers. ${ }^{103}$ The severity of the judicial processes and punishments after 1618 was distinctly religio-political, especially with Reinier Pauw as the dominant political player in Amsterdam. ${ }^{104}$ Because he was a staunch proponent of the CounterRemonstrant party, Pauw was appointed to sit on the council that judged Oldenbarnevelt, and condemned him to death. Moreover, in the context of the wetsverzetting of $1619,{ }^{105}$ he had helped cleanse the Amsterdam city council of its major Remonstrant figures. However, from 1621 onward - the year of Sapma's, Prince's, and Grevius' escape from prison - the moderate forces regained most of their strength, which led to the resurfacing of the political ideas of Oldenbarnevelt, Grotius, and their likes. Consequently, policies were defined much less in terms of dominium: less as a fusion of house-based and

101 Dirck Volckertszoon Coornhert, Boeventucht. The first ideas on the improvement of prisons and a more humane treatment of prisoners were developed when Coornhert himself was imprisoned in 1567 (see Arie-Jan Gelderblom's introduction to Boeventucht, pp. 12-13). Later these ideas were fully developed and published, with Boeventucht, Thieves' discipline, in 1587. 102 On the Amsterdam 'tuchthuis' in its European context see Pieter Spierenburg, The Prison Experience.

103 Elisabeth Lissenberg, 'Preface' to Spierenburg, The Prison Experience, p. 1.

104 Pauw was acting as burgomaster in 1605, 1609, 1611, 1614, 1616, 1617, 1619, and 1620.

105 'Wetsverzetting' was the legal term for the right of the stadholder to appoint members of the town councils in times of crisis. 
religious political rule, as Maurits and the Counter-Remonstrants desired. Instead, the cities, the states, and the States-General were considered more and more as public affairs, in the sense of a res publica.

In the context of a prosperous Republic that was indeed concerned with the res publica, torture did not disappear from one moment to the next. It did become less and less acceptable, however, losing its aura of legitimacy. Here, the Dutch Republic was, and was not, a particular case in Europe. As Clive Emsley has argued, it was only after 1750 that princes and sovereigns throughout Europe started reforming the juridical system that was founded on the Constitutio Criminalis Carolina from 1530, a document that had led to many witch trials and torture practices in the two centuries to follow. ${ }^{106}$ In light of this, the Dutch Republic was distinctly ahead of its time. ${ }^{107}$ Yet, according to John Langbein, torture was generally on the decline in Europe from the early seventeenth century onward, not so much due to passionate humanist pleas such as Coornhert's and Grevius' but due to 'the development of new criminal sanctions and the revolution in the law of proof'. ${ }^{108}$ Accordingly, Lisa Silverman in her study of torture in Early Modern France can state:

My evidence, like that of other historians, demonstrates a dramatic decline in the employment of torture from the beginning of the seventeenth century. But my evidence also shows a continued employment of torture $[\cdots]^{109}$

As Silverman goes on to explain, in line with Langbein's analysis, it was not so much because of legal requirements that torture was still employed but rather 'because it had a powerful cultural significance'. ${ }^{10}$

In terms of cultural significance, it is telling that torture was both made fun of and dealt with seriously in the Dutch Republic. A text that may prove this point is Jan Vos' play Aran en Titus of Wraak en weerwraak: treurspel (Aran and Titus: Revenge and Revenge in Retaliation: a Tragedy, 1641). The

106 Clive Emsley, Crime, Police and Penal Policy, especially the chapter 'Laws and Punishments'. 107 On the developments in the Dutch context, see Henk van Nierop, Het verraad van het Noorderkwartier for the sixteenth century and Lia van Gemert, 'Severing what was joined together' for the seventeenth century.

108 See John Langbein, Torture and the Law of Proof, and John Langbein, 'Torture and Plea Bargaining'; or Edward Peters, Torture.

109 Lisa Silverman, Tortured Subjects, p. 24. Silverman's findings are in line with Peter Paalvast, Martelen en martelwerktuigen in cultuurhistorische perspectief.

110 Silverman, Tortured Subjects, p. 24. 
play made an impression. In a letter from Barlaeus to Huygens, the former describes his own response, and the reactions of Hooft and Van der Burg, as well as that of Vondel, whose response to the play is recounted as follows: Audivit Vondelius, et portentosi ingenij virum dixit: 'Vondel has heard it and said it was a man of miraculous wit'."11 Yet, the choice of words may be translated more delicately, especially 'portentosi', which may also indicate 'unnatural', 'miscreant', or 'fantastic'. Indeed, it might seem a tragic play but it is also distinctly comical, as a result of which the theme of torture is also dealt with irreverently.

Whether or not Vos had read Shakespeare, his play is a clear intertextual allusion to, or reworking of, Shakespeare's Titus Andronicus. ${ }^{112}$ It is, moreover, an almost bizarre mixture of formal classicist requirements (such as the unity of time, the division in acts, the use of alexandrines) and baroque sensibilities (such as the excessive show of violence, the many unexpected turns in the plot, the extravagance of emotions). ${ }^{113}$ The characters in play in the last act - we have lost more than a few-are Saturninus, the emperor, and his wife Thamera, who was queen of the Goths and lover of Aran but who, in order to save the latter's life, has agreed to marry the emperor. Then there is Titus Andronicus, a general, with his brother Markus and son Lucius. And finally there is Aran, the black leader of the Goths who has succeeded in getting his revenge on the Romans by killing the emperor's brother. Thamera has just learned that Titus, who organized a dinner, has given her her own children to eat. In rage she has cried out for Aran, who was captured earlier but now suddenly bursts on stage through a 'loose Soldering': a trapdoor. ${ }^{114}$ This is how the play ends:

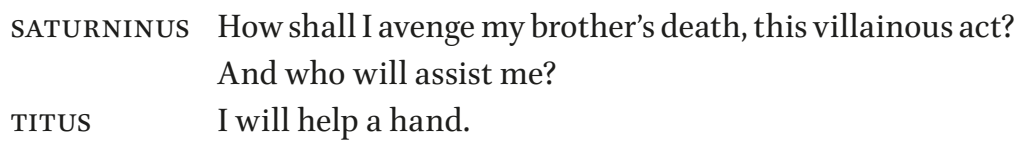

111 Constantijn Huygens, Briefwisseling. Deel 3: 1640-1644. The editor to Jan Vos' poems translated this in Dutch as 'Vondel heeft het gehoort, en zeide, ' $t$ is een man van wonderbaer verstandt'; Jan Vos, Alle de gedichten van de vermaarde poëetJan Vos - Tweede deel.Jacob Lescailje, Amsterdam 1671 .

112 On this see Jan Vos, Toneelwerken, p. 53 and 64, but more extensively Willy L. Braekman, 'The relationship of Shakespeare's Titus Andronicus to the German play of 1620 and to Jan Vos' play Aran en Titus'. See also Helmer Helmers, 'The Politics of Mobility'.

113 On this see Buitendijk in his introduction to Jan Vos, Toneelwerken, p. 59 and pp. 68-72.

114 Jan Vos, Toneelwerken, p. 208. 
(Opens trapdoor that drops Aran into a fire, hanging above a set of sharpened spikes.)

ARAN

TITUS

ARAN

TITUS

ARAN

TITUS

ARAN

TITUS

ARAN

TITUS

ARAN

TITUS

ARAN

TITUS

TITUS

SATURNINUS (slays Titus) There you have it, damned scoundrel, And now follow the bloody steps of Saturninus' bride. LUCIUS

Oh chilling fall, oh deadly pain!

Help Titus, Titus help! I will kiss your wrath.

Revenge shows you its neck.

Who will extinguish these flames?

The tears of your whore.

Mercy! Mercy! Mercy!

If evil acts are punished, then remorse comes too late.

Oh Titus, show mercy!

Revenge does not have ears.

Restrict the raving revenge of your incited anger.

If you had restricted your cruel hand in every act

Revenge in response had not come down on your head so fiercely.

Here lies in his grave who would have liked to wrap us in ours.

Oh overheated flames! Oh all too sharpened skewers.

Come Titus, Titus come, and splice my life on them.

First the raw flesh must be baked to the bone.

Help, ghosts! Ghosts help! I am in dire need of assistance.

Pour down, mad thunderer, pour down a vast rain

Or with your wrathful fist, lightnings, down on me,

So that I, in a split second, will perish to ashes.

Woe! Woe! Woe!

The villain has gone down already.

He lies as in the glowing embers of Etna's mountain caverns.

SATURNINUS Now my revenge has been fulfilled; my brother's spirit satisfied.

I am swimming in a sea full of exhilaration.

My heart bursts out from joy.

I will restrain the joy. (Slays Thamera)

There, black man's whore, have it, you will get your butt

friend

In the empire of hell.

Is father dead? Oh dead! By Saturninus' hands?

Tyrant, here is what you deserve! (Slays Saturninus) 
MARKUS

\section{Your imperial headscarves}

Are for Lucius now and what belongs to the empire.

Now it will be required that the Tyber's gate

And the spacious market field will be surrounded by your armies.

They will proclaim the monarch dead and you monarch

And all those who will oppose it, be they aristocrats

Will be off to the Black Sea, in eternal exile. ${ }^{115}$

There is much that is farcical in this passage, or bordering on the obscene. It starts with a hilarious ijsselijke or 'chilling' fall in a fire, proceeds with the one who is tortured in the fire asking who will extinguish it, which is then followed by the response that it can only be extinguished by the tears of the 'whore' of the one tortured. Then there is the threefold lyrical repetition by the one who is being roasted: 'Help Titus! Titus help!', 'Come Titus, Titus come', 'Help ghosts! Ghosts help!', and the dry funeral epitaph of 'Here lies [...]'. Those who have pictured the Etna, with its lethal glowing lava, will have pictured the sea on which it borders as well, hence Saturninus' sea of joy. There is a double pun on ' $p o l$ ', which can either mean slut or faggot. Yet, after the rapid and gory death of four characters, the play ends on a dry

115 Aran en Titus, ll. 2092-2126 in Jan Vos, Toneelwerken, pp. 208-10. In the original: 'Saturninus: Hoe zal ik Broeders doodt, hoe zal ik 't schelmstuk wreeken? Wie zal my bystandt doen? Titus: Ik zal u hulpzaam zijn. Aran: O ysselijke val! o doodelijke pijn! Help Titus! Titus help! ik zal uw gramschap kussen. Titus: De wraak keert u de nek. Aran: Wie zal deez' vlammen blussen? Titus: De traanen van uw' hoer. Aran: Genâ! genâ! genâ! Titus: Als 't quaaddoen wordt gestraft, dan komt 't berouw te spâ. Aran: O Titus! geef genâ. Titus: De wraaklust heeft geen ooren. Aran: Bepaal de woede wraak van uw' getergde tooren. Titus: Hadt gy u wreede handt, in al uw' doen, bepaalt. / De weerwraak was zoo fel niet op uw' hooft gedaalt. / Hier leit hy in zijn graf die ons in 't graf wou wikkelen. Aran: O overheete vlam! o al te scherpe prikkelen! / Kom Titus, Titus kom, en kerf mijn leevens draân. Titus: Eerst moet het rauwe vleesch tot op het been toe braân. Aran: Help spooken! spooken help! ik ben om hulp verlegen. / Stort dolle donderaar, stort nu een dichte regen, / Met uw' vergramde vuist, van blixems op my neêr; / Op dat ik, in der yl, tot assche toe, verteer. / O wee! o wee! o wee! Titus: De schelm is al gezonken; / Hy leit, als in de gloedt van AEtnas bergspelonken. Saturninus: $\mathrm{Nu}$ is mijn wraak vernoegt: mijn broeders geest gepait; / Ik zwem in ene zee van alle dartelheidt / Het hart springt me van vreugdt. Titus: Ik zal de vreugdt betoomen. / Daar moorehoer, hou daar; gy zult uw' pol bekoomen / In 't onderaardsche Rijk. Saturninus: Hou daar vervloekte guit, / En volg de bloedge schreên van Saturninus bruidt. Lucius: Is vaader doodt? o doodt! door Saturninus handen? / Tyran daar is uw' loon. Markus: Uw' Kaizerlijke banden / Zijn nu voor Lucius, en wat aan 't Rijk behoort. / Nu zal het noodig zijn, dat gy des Tybers poort, / En 't ruime marriktveldt, omheinigt met uw' troepen, / Dan zalmen 's Vorsten doodt, en u voor Vorst, uitroepen; / En wie'er teegens streeft, alwaar't de Ridderschap, / Zal voort naar Pontus Meir, in eeuwge ballingschap.' See: http://www.dbnl.org/titels/titel. php?id=vos_oo2arano1 (visited March 2017). 
note. A concluding line expresses the amoral or brutish nature of Rome's imperial power politics, and this line is crucial.

A decade after the first performance of Aran en Titus, the Dutch translation of Grevius' treatise was reworked and published in Dutch. ${ }^{116}$ With the Dutch Republic's turning away from or tempering of the powers that had preferred dominium-based politics, torture was on the decline as well, as is suggested by the reprints of this text in 1651, 1736, and 1740. A Latin version based on the earlier Dutch one was published in 1653 (De torturae abusu et necessaria moderatione, Dordrecht), and there was a pamphlet-like summary circulating through Rotterdam in 1690 . To be sure, it would take until 1798 before torture was officially abolished, and a century earlier, during the first stadholderless period, which Johan de Witt would call the period of 'The True Freedom', torture was still used. The point is that although it would take time, torture became less and less accepted. Consequently a dominium-based law had to be reconfigured.

Enough members of the populace in the Dutch Republic were fascinated by torture, whether home-grown or exotic. ${ }^{117}$ Yet there were many others who considered torture in the context of the perverse power structures that facilitated it. The issue of torture was embedded in and framed by a Roman heritage in terms of jurisdiction, politics, and aesthetics. This is what connects Vondel's destroyed tragedy on Messalina and Silius to Vos' surviving tragedy on Aran and Titus. The political perversion that is central to both plays concerns the fusion between dominium and imperium, a perversion that almost unexpectedly confronted those who were culturally reworking the Roman material in the Dutch Republic with, in the end, paradoxical material. This incompatibility, the fragmented or paradoxical nature of the relation between the Republic and Rome, was baroque in a republican way, which is to be distinguished from the princely or royal negotiations with the Roman paradigm. The struggle between the two would define the Republic until its very end, on which more will be added in the next chapter.

For now, let me conclude this chapter by adding a potentially confusing layer of nuance. The Roman paradigm not only worked allegorically in relation to the political organization of the Republic, but also in relation to its religious constituency, with Rome indicating the Roman Catholic Church. Did torture not relate to that Rome as well, or to Christianity at large? Let me move to the figure of Job to address this.

116 The author was a medic called Daniel Jonctys, De pyn-bankwedersproken, en bematigt (1651). 117 On this see Benjamin Schmidt's chapter 'Exotic Bodies: Sex and Violence Abroad', in Inventing Exoticism, pp. 163-226. 


\subsection{Catholic Rome and the figure of Job: subjection to the only possible world}

In Christianity, Job was often seen as a prefiguration of Christ, and by implication the New Testament. Consequently, in the course of the Middle Ages and the Early Modern period Job was taken up by the most important religious and humanist thinkers: from Jerome to Gregory the Great's massive Moralia in Iob at the end of the 6th century, and to Aquinas. Yet, he was also a dominant figure for the Protestants-Luther, Calvin, Beza- as well as the humanists, like Coornhert, for instance. Calvin, for one, gave no less than 159 sermons on Job in the years between 1554 and $1555 .{ }^{118}$ Whereas in the Catholic Middle Ages, Job was first and foremost an icon of Stoic fortitude, patience, and humility, the exempla patientiae, and an icon of purification through suffering, in the Reformation he also became the paradigmatic human figure accepting God's incomprehensibility and sovereign power. Around this issue, there was a radical divergence in Coornhert's and Calvin's understandings of Job: the former saw him as the hero of the story while the latter saw him as the object of another subject in that he was first and foremost proof of God's sovereign goodness. Nonetheless, the connecting theme was subjection, either because one chose to accept one's subjection or because this was the only thing to do when one's fate depended on an unknowable, omnipotent, sovereign, and — depending on the case — graceful God. ${ }^{119}$ All in all, one could call Job the paradigm of Christian subjection, as he subjected himself to the one and only world possible: a world ruled by God.

Vondel would summarize the message of the story of Job as follows: 'Are you beset by misery and disaster, be patient like Job' ('Drucken u ellende en ramspoed, zijt geduldig als Hiob'). ${ }^{120}$ And, when a picture book on the heroes of the Old Testament with poems by Vondel was published in 1620 , Job was used as a warning to those who commit the sin of complaining about God's sovereign actions. That said, Vondel would not want to miss the opportunity to sketch Job's hurt body in detail. No longer is the latter clothed in purple silk, but instead he is covered

... with a cloak rich in scabs of sores

Embroidered with pimples, crowned with a hat

118 On this see Susan Scheiner, Where Shall Wisdom Be Found?

119 See Jurgen Pieters, 'Coornhert en Calvijn over Job'.

120 Vondel, 'Iob' from De Helden Godes des Ouwden Verbonds/Met kunstige beeldenissen vertoont, en poeetelijck verklaert (The heroes of God), WB II, pp. 303-391. 
Of scabies, whose headscarf is nothing but puss, and filthy blood.

A pot shred will serve him as staff and scepter:

With which he opens up the sores, to be licked

With consent by his household dog's tongue, that, out of gain

Longs for the delicacies in Job's covered skin. ${ }^{121}$

Thus, we get an explicit picture of his misery. Reassuringly, we soon learn that Job will not truly suffer, and his body will not truly be in pain, because of his unwavering trust in God. In general, the message of this story to the audience is, according to Vondel:

We accept the evil from one who blessed us in the good:

Naked we came into the light: naked we fare in the dust:

Who lent it to us took His: the Lord be thanked and praised. ${ }^{122}$

This all seems to fit in nicely with commonplace sixteenth- and seventeenthcentury ideas. Yet, the passage fails to mention the big problem of theodicy as addressed by Leibniz: God gave us the good, to be sure, but if he also gave us evil, why would that have to be 'acceptable'?

Maimonides, in the third book of his twelfth-century Guide for the Perplexed, had already hinted at the issue of theodicy: the question of whether God could justifiably use evil. The issue was further developed in one of the pivotal debates of the seventeenth century, initiated by Descartes who asked how evil in a universe ruled by a perfect Being could be 'reasonable'. ${ }^{123}$ Leibniz's 1710 study into the origin of evil, officially entitled Essais de Théodicée sur la bonté de dieu, la liberte de l'homme et l'origine du mal, would not only coin the term 'theodicy' in his response to Descartes and Pierre Bayle, but also make the famous distinction between mental, physical, and metaphysical evil. ${ }^{124}$ Since the perfect Being had been equated with reason since Aquinas, the key question was not whether a sovereign God could use

121 Idem, 'Iob', WB II, p. 385, ll. 6-12. In the original: 'Maer met een mantel rijck van rooven en van zeeren / En puysten geborduurt, gemytert met een hoed / Van schurft, wiens lamper is slechts etter, en vuyl bloed. / De potscherf hem een staf en scepter wil verstrecken: / Waer mede hy open klouwt de zweeren, die hy lecken / Laet van zijns huyshonds tongh, die op haer voordeel uyt / Snackt na de leckerny van Hiobs bedragen huyt.'

122 Idem 'Iob', WB II, p. 385, ll. 26-28: 'Wy dulden 't quaed van hem die zegende ons in 't goede: / Naeckt rezen wy in 't licht: naeckt varen wy in 't stof: / Die 't leende nam ons 't zijn: den Heer zy danck en lof.

123 René Descartes, in the sixth meditation of his 'Meditations on First Philosophy'.

124 Gottfried Wilhelm Leibniz, Theodicy. 
evil at will, but, indeed, whether such use could be understandable and acceptable as reasonable.

There are elements in Vondel's text that hint at this problem. Via the motto Job tells us: 'If only my anguish could be weighed and all my misery be placed on the scales, It would surely outweigh the sand of the seas! ${ }^{125}$ This brings us not so much back to the complaining Job, but the one who suffers so much that it is beyond any reasonable scale. The image of the scale clearly alludes to the element of justice, as something that is in balance, or that should be corrected and balanced. Moreover, when Job is called a 'martyr' in line 25, the question is, of course, whether he pains himself or whether he is pained by an unjust power. This is alluded to in line 30 , where a rack is mentioned. The line is part of several verses that are so vexingly complex that they deserve quoting in full:

His friends and family resolutely seated next to him also to comfort, A rack provided this man's unwrinkled conscience, That, richly comforted in God by the practice of much good Was welcomed by a joyous company of virtues:... ${ }^{126}$

The second line is ambiguous. Read in context or on its own, the subject of the verb changes. The first line suggests that the friends and family, despite their comfort, 'provide' (strecken) Job's conscience with a rack, due to all their comments and remarks. Or, they become the very rack. Yet, if line 30 is read on its own, the subject of the verb is 'rack', and then strecken is associatively linked to the 'unwrinkled', as if Job's conscience was stretched by a rack (as in: 'A rack stretched this man's unwrinkled conscience'). Furthermore, there is the poetic repetition of 'comfort', linking the comfort of the family with God's, as a reward for the many good things that Job has done. Yet, God, as we have seen earlier, can give human beings the good and has the sovereign power to take it back, operating like a rack to torture an innocent man. I read the complexity that encircles the word 'rack' as a telling sign, here, a sign of disturbance.

As for torture, Job may be the first literary example we have of its principles. As Ariel Gluklich explains in Sacred Pain: Hurting the Body for the

125 In the original: 'Wanneer men myn jammer woege, en mijn lyden te zamen in een schale leyde, zoo zoude het zwaerder zijn dan het zand aen de zee.' The text is taken from the bookJob $6: 2-3$; this translation is from the New International Version of the Bible.

126 Vondel, 'Iob', WB II, p. 385, ll. 29-32: 'Zijn maeghschap oock tot troost vast neffens hem gezeten, / Een pijnbanck streckte schier's mans ongekreuckt geweten, / Dat rijck in God getroost door 't veel gepleeghde goed / Een blijde schare quam van deughden te gemoet:...' 
Sake of the Soul, the torture performed by the inquisition was not a matter of arbitrary, extended, or prolonged modes of hurting a victim. Torture had to follow strict procedural rules. ${ }^{127}$ There was a script-several scripts in fact - that defined what was to be done, when, how, and to what effect. This resonates with what God and the devil come up with when the devil suggests that Job only believes because he is not hurt. God and the devil agree upon the fact that Job has to be vexed first by gradually taking away all that is dear to him. When this does not work, they scale up the intensity of torture and start to hurt Job's body. In the context of the inquisition, so Glucklich states, the aim was not to make the victim, in this case Job, say what the torturer wanted him to say. As long as the victims of the inquisition asked what it was they had to admit, the torturer would go on, since the victim him- or herself apparently had not yet discovered what was to be admitted. The one tortured had to reach the phase in which he realized, in retrospect, what he had done wrong: the phase in which he himself wanted, willed, to admit what the torturer was looking for.

A pivotal difference should be noted here, and it is apparent in two studies that were published in the same year: Edward Peter's Torture, and Elaine Scarry's The Body in Pain: The Making and Unmaking of the World. ${ }^{128}$ The latter argued that there is a principal split between the world of the torturer and the world of the one tortured. The torturer is aiming to unmake the world of the one tortured, something that we will come back to in the next chapter. In contrast, Peters was following the historical trajectory, from Roman law to seventeenth-century practices of torture, in arguing that torture is aimed at reuniting the two in one world. What Peters defined as the torturer and the tortured becoming part of one world, connects to what Glucklich defined as 'dispositional guilt': a guilt that does not have a particular source but manifests as a general mood or attitude of guilt, one that can only exist on the basis of internalized repetition. Indeed, the story of Job is both retrospective and repetitive, aimed at the repetition of its content. Job is first indignant; he complains and asks what he could have done wrong. This is the element of retrospection. As for repetition: he keeps on asking what he has to do to stop the unbearable suffering. But this is only

127 Ariel Glucklich, Sacred Pain. On this see also Lisa Silverman, Tortured Subjects, Henry Kamen, The Spanish Inquisition, or Benzion Netanyahu, The Origins of the Inquisition in Fifteenth Century Spain. What Edward Peters in Inquisition calls 'the myth of the Inquisition' is that it introduced the horrors of torture. Yet it came to life as an attempt to regulate torture, to avoid illegal forms of torture on all levels of society, and to bind torture by means of procedure, pp. 153-154. 128 Edward Peters, Torture, and Elaine Scarry, The Body in Pain. The two were already read together in 1986 by none other than Peter Singer, 'Unspeakable Acts'. 
in order to get to the phase in which his will is to embrace the torture and torturer, in order to believe that whatever God contrives is 'just', and that God, therefore or by implication, is just. The point, evidently, is that Job is not simply to be made subject. Rather, he has to embrace his subjection in declaring himself forever guilty, as a human being.

In this context, Job is a figure who is framed, literally and figuratively: he is put on a stage to see what happens to him. As such, he is a distinctly theatrical figure whose function is to both embody and represent ultimate subjection to the only world possible. Still, in the Christian frame of mind the protest against torture had to lead to principal problems. Christianity was itself the spiritual heir to what it had first opposed: imperial Rome. The issue of theodicy, in this context, was neither abstract nor strictly moral, and perhaps it was not even theological. Rather, it was related to the way justice was dealt with in society.

In the religious strife that characterized the sixteenth century, the Inquisition, and by implication torture, had become a central point of concern, and a great topic for propaganda. Ironically, within a relatively short amount of time, the protestant parties who had depicted themselves first as the innocent victims of an unjust system, proceeded to engage in an inquisition of their own, with the case of Michael Servetus in 1553 as a turning point. ${ }^{129}$ Again, in the Dutch Republic after the Synod of Dordt in 1618 CounterRemonstrants were all too eager to use torture in their purification of the state in times when central authority was lacking, and when torture was less regulated. In effect, for some time, torture was almost rampant. A horrible illustration is the 1627 case of painter and freethinker Johannes Torrentius, who was brutally tortured on the basis of fabricated allegations by the orthodox ministers Henricus Geesteranus and Dyonisius Spranckhuysen. ${ }^{130}$ Within the frame of Christianity, whether it be Catholic or Protestant, torture followed a logic that was familiarized through the Job story. It was a logic, moreover, that was intrinsically linked to the establishment of

129 Edward Peters, Inquisition, pp. 155-188. Servetus, or, Miguel Serveto y Reves, is perhaps not too well known for an Anglo-Saxon audience, but in the Latin world, he is prominent. On this see: http://www.miguelservet.org/servetus/web.php, or in chronological order: Ronald H. Bainton, Michel Servet: hérétique et martyr (1553-1953); Vincent Schmid, Michel Servet: du bûcher à la liberté de conscience; Juan Naya and Marian Hillar, eds., Michael Servetus, Heartfelt. On Calvin's role in the matter, and the general context of this struggle, see Benjamin J. Kaplan, Divided by Faith, pp. 15-72 or Alister E. McGrath, Johannes Calvijn, pp. 140-147.

130 On Torrentius' life, his work, and this case, see Wim Cerutti, Haarlems-Amsterdamse duivelskunstenaar. The report of the torturers' severe work on Torrentius can be found at: https://www. amorc.nl/over-amorc/geschiedenis/johannes-torrentius 
the Church, again be it Catholic or Protestant, as the safeguard of societal order and as the dominant vehicle of subjection. To achieve this, the logic of torture functioned both dramatically and theatrically.

Torture, enacted in isolated spaces that are not visible to a general audience, is dramatic. In the torture scene, the distinction between audience and actors is almost non-existent. All the actors in play are taken up in the action. Yet, this dramatic and in a way not representable situation becomes framed theatrically because of a pivotal anticipation: the entire scene is only acted out dramatically with the aim of being brought into the light on a representational stage. What has happened needs to be brought forward and shown through representation, by means of retrospection, in order to serve the aim of general subjection. Job has to be humiliated publicly; it has to be seen what happened to him, not in the confines and privacy of his house, but out on the street, showing his pain and suffering. Job's case helps to show how the logic of torture relates, generically, to a dramatic and a theatrical situation, in which the theatrical is anticipated and thus superimposes itself on the dramatic.

Taken together, the hidden dramatic and the public theatrical display of torture serves not so much to establish one world, but to close one as the only possible one. In this context, Job could no longer be a dominant figure in a republican baroque. To be sure, this was not only a republican matter but also one of general enlightenment. As John R. Yamamoto-Wilson noted: 'During the last two decades of the seventeenth century it became almost a commonplace to reject the Stoic attitude toward pain, while at the same time discussion of pain and suffering intensified, becoming more varied, more profound, and more prolific than during the first eight decades of the century put together. ${ }^{131}$ Thus, it is no coincidence that the figure of Job begins to 'fade out'. Once he had been at the center of cultural attention, but now, at a time when torture was provided with more justifiable and reasonable alternatives - especially in the Republic, thanks to, among other developments, the pioneering role of the Amsterdam prison-Job could no longer be paradigmatic. Whereas in the Catholic Middle Ages torture was aimed at bringing torturer and tortured together in one world, the split between state and God that started to materialize in the seventeenth century implied a radical separation of torturer and tortured.

This separation led, on the one hand, to forms of torture that were aimed less at the unification of two worlds into one, and more at the unmaking of one world in order to install or allow another one to rule. On the other 
hand, the separation implied a farewell to the logic of torture and perhaps started to open the possibility of what Deleuze termed a logic of cruelty, one related to the unavoidably painful political division, intended or not, between two or more incompatible worlds. The case of the brothers De Witt, central to the next chapter, relates to both options. 


\section{The cruel death of worlds and political incompatibility - the brothers De Witt}

\subsection{Foundations of law: the master/father of a political house}

The proverb wants it that when God closes a door, he will open a window. Politically speaking such an alternative window cannot be opened so easily, since the opening up of a new world implies the attempt to close another. I will be dealing with such an attempt in this chapter, an attempt provoked by the opening of another world: a republican one. The Republic had come into being because of the fact that subjects could no longer accept life under the rule of a tyrant. The term 'tyranny' had a considerable background in medieval and classical history, but in the years leading up to the Dutch Republic its most direct connotation was King Philip II. With the Plakkaat van Verlatinge, or Act of Abjuration, the States-General of the United Provinces of the Low Countries had proclaimed in 1581:

As it is apparent to all that a prince is constituted by God to be ruler of a people, to defend them from oppression and violence as the shepherd his sheep; and whereas God did not create the people slaves to their prince, to obey his commands, whether right or wrong, but rather the prince for the sake of the subjects (without which he could be no prince), to govern them according to equity, to love and support them as a father his children or a shepherd his flock, and even at the hazard of life to defend and preserve them. And when he does not behave thus, but, on the contrary, oppresses them, seeking opportunities to infringe their ancient customs and privileges, exacting from them slavish compliance, then he is no longer a prince, but a tyrant, and the subjects are to consider him in no other view. ${ }^{132}$

132 The original text and the translation can be found together on the Groningen website established by George M. Welling, 'American History: From Revolution to Reconstruction and Beyond': http://www.let.rug.nl/usa/documents/before-16oo/plakkaat-van-verlatinghe1581-july-26.php. The original: 'Alsoo een yegelick kennelick is, dat een Prince van den lande van Godt gestelt is hooft over zijne ondersaten, om deselve te bewaren ende beschermen van alle ongelijk, overlast ende ghewelt gelijck een herder tot bewaernisse van zijne schapen: En dat d'ondersaten niet en sijn van Godt geschapen tot behoef van den Prince om hem in alles wat hy beveelt, weder het goddelick of ongoddelick, recht of onrecht is, onderdanig te wesen en als slaven te dienen: maer den Prince om d'ondersaten wille, sonder dewelcke hy geen Prince en 
The word 'tyrant' (tyran) is explicitly used in the text, indicating a ruler who considers his subjects to be slaves. In contrast and originally, so the Act argues, this is not how God conceived of 'people'. Yet, although the English translation uses the term 'people,' here, the original uses a specifical politico-juridical term: ondersaten, that is to say: subjects. And even though the translator's choice of 'people' could be called adequate, it is only so in the most general sense. Obviously, God did not make political subjects, rather he granted the king the right to rule and to take care of his subjects. Yet he did create people politically in the sense that they were to be free.

The original text of the Plakkaat plays with a choice between two options: God made man (male and female) who would later become a political subject but not a slave, and God meant political subjects not to be slaves but since they were clearly child-like they were in need of a father-like figure or a shepherd. Politically, this implied that man was either not made free but rather like a child in need of princely and fatherly guidance, or, he was created free but people would choose to become like sheep in order to form a polity. In this respect, the Plakkaat mixes two familiar versions of sovereignty, which Quentin Skinner saw as 'one of the deepest divisions in modern European political thought': the sovereignty of man, and by implication the people, and that of the prince. ${ }^{133}$ These two had been at the basis of different conceptualizations of sovereignty by, among others, Jean Bodin and Johannes Althusius in the previous century. ${ }^{134}$ In the seventeenth century they were followed by figures such as Robert Filmer and Thomas Hobbes on the one hand, and John Locke, John Milton, and the movement of the Levellers on the other. Whereas Bodin, Filmer, and Hobbes argued, in different ways, that the state could be the only and supreme political power, embodied in the prince or the sovereign, Althusius, Locke, Milton, and the Levellers would argue that a man's individual right to liberty can neither be given away, nor usurped.

Basically, and despite Skinner's thesis that this was a modern split, this opposition troubled the history of European politics from the very

is, om deselve met recht ende redene te regeeren ende voor te staen ende lief te hebben als een vader zijne kinderen ende een herder zijne schapen, die zijn lijf ende leven set om deselve te bewaren. En so wanneer hy sulx niet en doet, maer in stede van zijne ondersaten te beschermen, deselve soeckt te verdrucken, t'overlasten, heure oude vryheyt, privilegien ende oude herkomen te benemen, ende heur te gebieden ende gebruycken als slaven, moet ghehouden worden niet als Prince, maer als een tyran ende voor sulx nae recht ende redene magh ten minsten van zijne ondersaten...'

133 See chapter 1 and note 83 .

134 On Bodin and Althusius, see Alain de Benoist, 'What is Sovereignty', pp. 24-35. 
beginning. This is at least what Hannah Arendt argued in her analysis of classical Greek political thought and its admiration for despots. In relation to what follows, it is key that the Greek word despotès meant 'lord of the house' or 'ruler'. ${ }^{135}$ Arendt's analysis finds a strong analogy in the early fourteenth century, when Marsilius of Padua in his Defensor pacis (1324) criticized what he considered to be a wrong turn in European politics under the Roman Catholic Church. This wrong turn followed from the fact that the father of an oikos (a household, in this case, the Church) tried to rule public affairs. ${ }^{136}$

In relation to these debates it is important to remind oneself that Grevius, whom we met in the previous chapter, had stated that torture and slavery were connected in origin because both were defined by the concept of dominium and the master that ruled it:

No one can doubt that this violence took its first origin from that absolute power of masters toward their slaves, which pertains to the fact that the entire concept of Interrogations in the Digests, restricts itself to slaves only, and states that it was not immediately from the beginning used against free men, when the Romans took over the habit of torturing from elsewhere. ${ }^{137}$

Grevius was referring here to the Justinian Digest in which 'interrogation' or quaestio is the common name for torture. ${ }^{13^{8}}$ With respect to this, he was much ahead of his time, since his astute argument conformed to later, nineteenth-century ideas. In the last decades of that century the great historian and legal scholar Theodor Mommsen, for example, argued that 'Roman domestic discipline was the basis of later Roman penal procedure in civil and criminal law'. ${ }^{39}$ The torture that was codified in Roman law had

135 Hannah Arendt developed these ideas, for instance, in The Human Condition, pp. 195 and 222-223, but also in The Promise of Politics, and especially in an article entitled 'The Great Tradition II: Ruling and Being Ruled'. See also Keith Breen, 'Law beyond Command?'.

136 Marsilius of Padua, The Defender of the Peace. On the history of Western political thought on this issue, see Quentin Skinner, The Foundations of Modern Political Thought.

137 Grevius, Tribunal, Lib. 1, caput II, par. VII. In the original: 'Ab aboluta illa Dominorum in mancipia sua potestate, primam exstitisse, truculentiae huius orgininem nemini dubium esse poterit, qui ad illud attenderit, totum illum de Quaestionibus in Digestis titulum, nil pene nisi servos crepare, atque non initio statim, hunc, cum torquendi morem aliunde asciscerent Romani, in libera corpora usitatum fuisse.'

138 See Esther Cohen, The Modulated Scream, p. 163: 'The most common name for torture in the Digest is quaestio. So common is the usage throughout the sections dealing with torture that one cannot speak even of circumlocution or euphemisms.'

139 Quoted in Edward Peters, Torture, p. 19. 
its origin in forms of criminal law relating to dominium - that is, to early forms of law relating to the master of a house and the ones belonging to that house. Within the confines of his own dominium the master of the house was legally entitled to deal with his property as he saw fit, including his slaves, who were not legal subjects and who could be tortured legitimately to preserve order, punish them, or extract information regarding crimes. At first, this right to torture was not only preserved for, but also strictly limited to slaves. Torturing free citizens was principally forbidden.

As for slaves, one of the worst crimes they could commit was killing the master of the house. In the context of Roman jurisprudence, this became a case analogous to parricide, to killing the father. The slippage from master to father in effect radicalized the nature of the laws in question, and turned the preservation of order into a more symbolically charged issue. When the law regarding juridical matters in a house or household was transplanted to the public domain, as was the case after the Roman Republic had changed into an empire led by an Augustus or Caesar, the consequences were considerable. As R.C. van Caenegem put it, the key characteristic of the late Roman Empire was that:

...its millions of multiracial inhabitants were subjected to one common domination [...]: all public authority had been vested in the emperor or descended from him. This emperor-called dominus since Diocletian (d. 316) — was absolute, i.e. not bound by the law, as he himself was its supreme source. ${ }^{140}$

Legally speaking, public affairs became increasingly encapsulated by the framework of the dominium or household. The ruler of public affairs was seen as the master of the house or, symbolically, as its father. Edward Peters, basing himself on Floyd Seyward Lear's Treason in Roman and Germanic Law from 1965, recalls that in the Roman doctrine of treason:

...the crimen laesae maiestatis, the injuring or diminishing of majesty, grew out of early Roman religious sanctions against the killing of a father, parricidium, and the actions of a Roman who becomes an enemy of his own community and aids its enemies, perduellio. ${ }^{141}$

140 R.C. van Caenegem, An Historical Introduction to Western Constitutional Law. 141 Floyd Seyward Lear, Treason in Roman and Germanic Law. The quote is from Peters, Torture, p. 25 . 
From the end of the Roman Republic to its imperial reconfiguration it was a relatively short route to the conflation of people, state, and ruler. One who injured maiestas simultaneously injured the communion, the state, and its 'father': the ruler or, in Early Modern terms, the prince. Consequently, the right to torture someone was extended far beyond the realms of slavedom. Anybody could now be tortured, including free citizens, because the Roman State had become a familia with the emperor (and before that the consuls) as the pater familias. ${ }^{142}$

It is not hard to see how this almost seamlessly applies to the European situation in the seventeenth century, partly due to the fact that Roman law had become the prime influence in codifications of law in the nascent European states. The two odd cases here were, aside from the Republic of Venice, England and the Dutch Republic. Still, what Skinner saw as the resurgence of the neo-Roman theory of freedom and self-government in England was developed in a situation where common law prevailed, whereas in the Republic Philip II had given the Low Countries their first codified law in 1570 by means of his Criminal ordinance (preceding the French Grand ordonnance criminelle of 1670 by a century). Yet, the Criminal ordinance's implementation had never been successful. ${ }^{143}$ In the Republic, moreover, the legal system had lost, temporarily, its codifying political center. Especially in the situation after the Synod of Dordt, with processes of legal administration strewn across approximately a hundred different courts, religious parties infiltrated the judicial system. In this context, it bears repeating that the Roman law against parricide originated in religious sanctions, and that in the course of Roman history a conflation took place that went on to play a pivotal role in the Counter-Remonstrant policy of purifying the state. The purification that took place was founded on the idea that the state was a household ruled by a father, in this case either the prince sanctioned by God or God himself, whose majesty was beyond all other majesties.

The Dutch and the English cases stand in especially stark contrast when one considers how English Parliamentarians proceeded to realize what Van Caenegem called a 'radical clean up' (although true legal reform was in the end not successful) in 1649. In England the Parliamentarians acted against the King's desire for centralization. In the Dutch Republic the opposite was the case. The States were sovereign and there was no high court on the level of the States-General. Cities had their own courts and had rights

142 On this transition and the legal practice at stake, see Jane Pölönen, 'Plebeians and Repression of Crime in the Roman Empire'.

143 See Ludwig von Bar, A History of Continental Criminal Law, pp. 304-o6. 
that could not be infringed upon by higher courts. In response, especially under Maurits and his grandson William II, the impetus was to achieve a one-state-one-religion system. ${ }^{144}$

The similarities and differences between England and the Republic, but also internal contradictions in each country, can be traced throughout the century in their readings of Tacitus, asserted Charles-Edouard Levillain. Levillain considered these readings in terms of 'the use and misuse of Roman history for propaganda purposes'. ${ }^{145}$ Next to Machiavellism, according to Levillain, one could even speak of Tacitism in the context of DutchEnglish debates on republicanism and sovereignty. Levillain reconstructs, for instance, how Grotius had interpreted Tacitus as describing how liberty and monarchy were nearly irreconcilable, which is why Grotius could glorify the Batavians who only accepted kings in name, while for the lesser-known scholar Marcus Zuerius van Boxhorn, Tacitus had described the opposite: how a country or a state that did not want to end up in ruin needed to be ruled by a monarchical power. ${ }^{146}$ That being said, such a power would have been unwise to call himself monarch in the seventeenth-century Netherlands. William III decided not to be unwise, although, in the English context, of course, William III would become king. Accordingly, Tacitus was read in yet another way here, as explaining the way in which monarchical rule, as opposed to republican self-government, depended on the nature and use of military men, and by consequence, the army.

The 'use and misuse' of a Roman paradigm was characteristic of almost an entire century, then. Considered as a conflict over the (in)distinction between state and religion, the Remonstrants' and Counter-Remonstrants' battle over man's free or unfree status in the Republic coincided historically and by analogy with the shift from torture as reserved for slaves to torture as principally applicable to all subjects. According to the logic of predestination, all subjects were in the hands of the Father to whose house they all belonged, and who could punish them as He saw fit. In the years following the Synod of Dordt, enough actors were willing to act as God's instrument in this punishment. Their ideas were not so different, by the way, from those who would argue that the prince or king was the master-father of the political household. Such an argument was made by Robert Filmer in his tellingly titled treatise, Patriacha or the Natural Powers of Kings, a

144 Van Caenegem, An Historical Introduction to Western Constitutional Law, p. 118.

145 Charles-Edouard Levillain, 'William III's Military and Political Career in Neo-Roman Context 1672-1702', especially p. 322 .

146 Levillain, 'William III's Military and Political Career', p. 331. 
treatise published in 1680 but written in the 1620 s and 1630 s that gained fame especially because of John Locke's response to it. Filmer's treatise, basing itself on Genesis 1:26-28, held that the basis of the political organization of the state was the obedience a family owed their father. ${ }^{147}$ Filmer was part here of a broader movement that was defined by Gordon J. Schochet in 1975 as 'patriarchalism': the conflation of paternal and monarchical power. Although one of this movement's major sources was the Bible, it was also as neo-Roman as Skinner's 'republicanism'. ${ }^{148}$

The battle against torture, therefore, was not just a moral battle. Grevius' contention that there is not one argument that is tenable in the defense of torture, for example, extended beyond the moral. The rhetorical target of his treatise was the prince, as the head of state. Having come to the end of his treatise, Grevius proposed that every sentence involving torture should be signed personally by the Christian magistrate. ${ }^{149}$ This came down to saying that torture, in the end, was a legal and political issue and, as such, connected to a specific form of rule. And indeed it was. It was so legally speaking and in light of the European political shift towards redefining affairs of politics as public affairs, not private or domestic ones. In the Dutch Republic this long-term European political battle intensified into one of its telling historical moments, a closing moment, with the lynching of the brothers De Witt, in 1672 .

\subsection{The lynching of the De Witts: condensation and spectacle}

In 1678 the Rotterdam-based painter Lieve Verschuier (1627-1686) made a work given the following title in a catalogue from 1801: 'The execution of the surgeon on the ship of J. van Nes, who had given poison to the Admiral, on the river Meuse near Rotterdam'. ${ }^{150}$ This Jan Jansse van Nes (1631-1680) was the brother of lieutenant-admiral Aert Jansse van Nes (1626-1693), who had been more or less the stand in for Michiel de Ruyter and, as such, acquired the nickname of the 'Dutch Ajax'. Jan van Nes had been a vice admiral of the United Provinces from 1673 onward, and his flagship had been the Virgin of

147 Robert Filmer, Patriarcha and Other Writings. The text can be found online: http://www. constitution.org/eng/patriarcha.htm

148 See also chapter 1; and see Gordon J. Schochet, Patriarchalism and Political Thought.

149 Grevius, Tribunal, pp. 492-98.

150 In the original: 'De executie van den chirurgijn op 't schip van J.van Nes, over 't ingeeven van vergif aan zijn Admiraal op de Maas voor Rotterdam'. The title was discovered by maritime historian R.B. Prud'homme van Reine, see "t Paerlen op de kroon der Gallerij'. 
Dordrecht (see figure 6). The catalogue's title of the painting was explained in the nineteenth century with the story that the surgeon was not really put to death but simply punished by keelhauling, because admiral Van Nes had forgiven him. Maritime historian Prud'homme van Reine drily remarks that this seems highly unlikely, since there are no records of this event, and insubordination as extreme as poisoning would have been a major offense in the maritime world. ${ }^{151}$ This was a world, moreover, in which one documented almost everything when it came to crime and punishment. There are several other aspects of the painting, moreover, that do not fit its title. Prud'homme van Reine analyzed this, and I will follow his reading here.

First of all, the ship at the center of the spectacle, with the man hanging and waiting to be thrown into the water, is too small to be an admiral's ship. It carries only 20 cannons instead of the average 6o. Then, its backside or spiegel (poop) carries a fictional coat of arms with two orange lions. This would be odd if it were the admiral's ship of Van Nes. The ship to the left is a type of ship that was used by the States-General or one of the Provinces, a so-called Statenjacht (literally a 'ship of state'). This merits emphasis; the surprisingly small but central vessel of the painting floats next to a warship that could metaphorically indicate the ship of state, a metaphor introduced by Plato in Republic VI. With this in mind, it is telling that the painting is abundant in the color orange. This brings Prud'homme van Reine to the question of who might have ordered this piece. It would certainly have to have been a supporter of the House of Orange; perhaps someone responsible for administering justice; someone who acquired some wealth, since this was a large and expensive painting; and it could have been someone involved in issues of the 'ship of state'.

In the Republic, the 'ship of state' had been ruled in previous years, from 1651 to 1672 , by the regents of the states. The leaders of the states-oriented party had been the two brothers De Witt:Johan and Cornelis. What was later defined as the 'First stadholderless era' was at the time called the period of 'true freedom' (Ware vrijheid) by the dominant political figure Johan de Witt, Grand Pensionary of the States of Holland. The era was defined as such not because people were free in the modern sense of the word but because the regents were free from any other dominating power, such as the stadholder's. This, of course, did not mean that the stadholder had simply disappeared. When, early on, in 1654, Johan de Witt and his companions abolished the hereditary nature of the stadholder position and De Witt had to defend this position in the States-General, he was much aided by the fact

151 R.B. Prud'homme van Reine, "t Paerlen op de kroon der Gallerij', p. 108. 
that William III, son of the deceased stadholder William II, was only four years old. ${ }^{152}$ Yet, by 1666 the young William III had become a political player of importance, in part because of considerable popular and elite support, while Johan de Witt had lost much popularity.

Adding everything up, Prud'homme van Reine suggests that the man commissioning the Verschuier painting could only have been Johan Kievit. The latter had fled to England in 1666 because of the so-called Buat complot against Johan de Witt, in which he had taken part. In England, he had become a favorite of Charles II, who made him baronet. In 1672 he returned to the Republic on a Statenjacht, welcomed by a large Rotterdam crowd. In The Hague, a little later, he and his brother-in-law, admiral Cornelis Tromp, witnessed the fruition of their prior plotting: the lynching of the brothers De Witt. After the De Witt's removal and William III's return to power, Kievit was appointed as advocaat-fiscaal, an officer of justice, in 1673. A little later he became burgomaster of Rotterdam. Kievit used his new administrative positions to amass wealth. The painting could have been ordered to decorate the opulent mansion he had built in 1678 .

As I read it, the painting is a matter of condensation, then, in which the glorious return of Kievit on a Statenjacht, the administration of maritime law, and the lynching of the brothers De Witt as improper captains of the ship of state coincide. The painting is formally theatrical, in the sense that it re-stages something, namely a glorious return. It is also so in content, showing a hanging or a lynching with an audience surrounding what is staged. Yet, a spectacular model superimposes the format of the theater, here. The man hanging is not an actor, and the audience has not gathered to be implicated in a theatrical division between an inside and an outside. They have come for a thrill, invited by a ruler who wants to show his power spectacularly.

In general, representations of maritime forms of punishment in the Dutch Republic are extremely hard to find. In a society in which the maritime world was part of everyday life this is surely strange, especially considering that print and visual media were abundantly present and the audience at large was fascinated by bodies in pain. Still, a fairly obvious domain of social life in which bodies were being hurt was not 'in the picture'. There are plentiful reproductions that depict, for instance, how people were punished in the so-called rasp houses. By contrast, Prud'homme van Reine noted,

152 On the brothers, see Luc Panhuysen, De ware vrijheid, and on the key text in which the function of the stadholder was propagated to be abolished, see S. ter Braake, Manifest van de ware vrijheid. 
'From the seventeenth century itself we have only a very small number of representations of the execution of maritime punishment. ${ }^{153}$ Why was it not represented? Why was it not on theatrical display? One obvious reason for the relative absence of representations of maritime punishment could be that companies such as the Voc and wIC, the Verenigde Oostindische Compagnie (United East Indian Company) and the Westindische Compagnie (West Indian Company), were not eager to make it even more unattractive to work on ships. Another reason could be that the punishment on ships was not aimed at subjection for political or societal reasons, but aimed at survival.

I suggest that the pain inflicted on ships in the seventeenth century was not shown to a large, public audience in a theatrical sense because its point was more that it was done, dramatically, in the enclosed space of a ship community. Although this case may seem particular, it has more general implications for a distinction between different modes of societal subjection that follow a different generic logic, namely the logic of the spectacle, the theater, or of drama. In this context, the painting's theme is also an application of punishment on ships, something that should in general be understood dramatically. On the ships there was a sort of podium that marked off a specific space distinct from its everyday usage; a normal mast became a place of punishment. Instead of the scene being defined by a frame, one might better speak of a different level or a different intensity, here. All the actors involved would be subjected not so much on the level of representation but in practice.

In this light, on the level of diegesis, the painting would work differently, bringing us back to a dramatic moment, which in this case would either be the dramatic moment of someone being hung on a ship or the dramatic moment of the brothers De Witt being lynched. To bring us back to this dramatic moment, however, the theatrical frame of the painting, the frame of representation, has to be ruptured. And indeed, such a rupturing element is present, although it is easy to miss. Yet, once noted, it is unavoidable.

There are nineteen flags depicted, predominantly the national tricolor, and there is one pennant, also the national tricolor, flying center stage. Straight underneath it the convicted man is hanging. The peculiar thing is that all eleven flags to the left are pointing toward the left, as if the wind is coming from the right, whereas all eight flags to the right of the pennant and the hanging man are pointing to the right, as if the wind is coming from the left. For any painter only tangentially familiar with circumstances on Dutch waters, this is impossible in reality. To be sure, winds can be turbulent, but

153 Prud'homme van Reine, 't Paerlen op de kroon der Gallerij', p. 109. 
then the flags should have been pointing in various directions. As it is now, it is as if the wind is blowing from the center of the painting, a center that consists of the white sky behind, the flying pennant above, and the lonely figure of the convicted, hanging man.

The artificiality of this 'wind' from the center is distinct. Yet it is not theatrical. It concerns something that is in effect unrepresentable, since the thing to be represented does not exist. Representing it nevertheless, the painting both stages a theatrical event, and produces a dramatic moment leading to something new, capturing the true nature of a dramatic moment. Something unpredictable is being actualized, and at the same time a certain world is being foreclosed, cruelly.

\subsection{The ship of state and the cruel political choice between incompatible worlds}

The comparison of the state with a house or household — and by consequence the comparison of the ruler of the state with a master/father - was a powerful metaphor that determined debates and thoughts on state justice as far back as antiquity. A paradigmatic case in point would be the previously mentioned Robert Filmer, who argued in Patriarcha that under the rule of a father-king, subjects have no other option than to subject themselves obediently. ${ }^{154}$ Yet, in the Republic another metaphor became increasingly important in the course of the seventeenth century. The already mentioned Platonic comparison between the state and a ship implied that the ruler of the state would be compared to a captain. This captain would be in the service of yet another power, but this higher power would not be simply a sovereign God.

In Printed Pandemonium: Popular Print and Politics in the Netherlands 1650-1672, Michel Reinders explains the connotations of the ship of state in the Dutch context in terms of the tension between absolute, masterly authority on the one hand and rule by means of interdependence on the other hand, which could well accord with a metaphorical father-captain. Those supporting the latter option would of course give a distinct meaning to the metaphor of 'the ship of state'. In this metaphorical ship,

regents steered the ship and set the course, but the citizens were the passengers, and whatever the regents did affected the entire ship. If the course was good, the passengers obeyed without a problem, but if the 
captains steered the vessel towards disaster, the passengers would not sit and wait. If a ship was in danger, the lieutenants and the common sailors were entitled to change course and correct the captain. Apparently [...] citizens had little trouble understanding the impending doom for which their ship of state was heading in $1672 .{ }^{155}$

On the face of it, the metaphor sounds pleasantly reasonable, just as it did from Plato's Republic with its enlightened captain of the ship. Yet, it is obviously not a mere matter of detail how a captain should be 'corrected' by his crew when he believes himself to be on the right course, or, for that matter, how the captain is allowed to correct his crew and passengers when he believes them to be wrong.

The element of correction may be of help in making the distinction between two modes of subjection. One would be subjection simple, by means of torture, for instance. Yet, the experiment that had started with the Amsterdam prison or rasp house aimed at avoiding torture as a mode of subjection in order to implant correction as subjection. Tellingly, the rasp house was led by a 'father', who was superior to a 'master of discipline'. ${ }^{156}$ Equally telling is the fact that one of the greatest admirals of the seventeenth century, Michiel de Ruyter, was lovingly called bestevaer, originally: 'grandfather'. He was not the master of a house, then, but was apparently still supposed to caretake and rule as a mild father. Such a figure could surely not be a torturer. Whereas the master-father of a household was the evident power to be obeyed, the father-captain of a ship had to be someone who was obeyed on the basis of his authority: that is, obeyed when he was adequately in charge. Moreover, he was not allowed to torture anyone. The implications of the metaphor 'the ship of state' were therefore considerable, in the context of how states dealt with and dealt out justice.

Considered from its dramatic center, Verschuier's painting affects its audience due to its reference to the political event of the lynching of the brothers De Witt, to some traumatic and to others joyous. It was a moment at which people were not watching a framed 'play' but were taking things to another level by becoming actors in the very thing they were also an audience to. Theatrically speaking, in terms of public visibility, the hanging figure in the painting was a criminal who was convicted according to maritime law and whose punishment was turned into a collective spectacle. Dramatically speaking, the hanging man was an icon for the mutilated

155 Michel Reinders, Printed Pandemonium, p. 201.

156 Spierenburg, The Prison Experience, p. 108. 
bodies of the brothers who were torn apart and left behind in the center of The Hague, not as the focal point of a spectacle but as silent witnesses to a dramatic moment that was captured as an event in a painting by Jan de Baen (1633-1702) (see figures 7 and 8). In fact, if we compare the body of the hanging man in the Verschuier painting, in solitude, with this painting by Jan de Baen, in which the naked and torn bodies of the De Witts are represented, the two visually rhyme.

As a representation the painting is a remarkable celebration ordered by a conspirator who keeps boasting, with hindsight, about the spectacular success of his attempts to murder the political leaders of the country. In its theatrical repetition the painting follows a logic of torture, as if the same thing has to be done again and again in order to destroy or unmake, as Elaine Scarry argued, a world: the political, republican world of the De Witts. ${ }^{157}$ No fusion of two different worlds is possible or called for politically speaking. The painting serves the repetition of an imprint, here, of a destroyed world that needs to be destroyed time and again in order to subject. At the same time, there is the unhinging element of the flags that destroy the repetitive frame because they fly from a center that defies representation. Through this, what happened to the brothers De Witt is being defined dramatically, as the un-representable moment in which politics was changed and a state redefined. Read as such, it would be a cruel picture to be sure, but not crueler, one could argue, than the handling of justice on ships. It would neither relate to the fusion between two worlds, nor to the making or unmaking of 'the' world. In fact, it would relate to the political issue of the coexistence of, and the necessary political but ultimately cruel choice between, not just different but incompatible worlds. ${ }^{158}$

One caveat is called for in relation to my use of the term 'cruel', here. The concept of cruelty is dealt with extensively in a study by John R. YamamotoWilson, entitled Pain, Pleasure and Perversity. ${ }^{159}$ At the basis of YamamotoWilson's dealing with the issue is Daniel Baraz's detection of a shift between the medieval and Early Modern sense of cruelty, which for Baraz is 'the shift away from the medieval ethical system that emphasized intentions to one that focused on actions'. That is, it came to matter less why people had

157 The same argument is made by Paul W. Kahn in a chapter entitled 'Torture and Sovereignty': '...the political act of torture is structured around an act of compelled speech. The issue is not information (the answer to the question), but rather the acknowledgment of power (the deconstruction of one world of meaning and the construction of another).' See Paul W. Kahn, Sacred Violence, pp. 21-41; the quote is from p. 23.

158 H. Perry Chapman, 'Propagandist Prints, Reaffirming Paintings'.

159 John R. Yamamoto-Wilson, Pain, Pleasure and Perversity. 
acted cruelly whereas it came to matter more how, and to what extent, they had acted cruelly. ${ }^{160}$ Yet, as Yamamoto-Wilson rightly argues, the sixteenth century is different, here, from the seventeenth century. Suffering was defined in terms of its punitive or redemptive potential within the frame of causality or motivation; it always had to make sense. By contrast, cruelty was a perversion of justice or of human nature itself. Still, however distinct it was from suffering, it could only be seen in light of it. It should always be seen, that is, within some sort of theological or moralistic frame. ${ }^{161}$

In contrast with this I would like to preserve the term 'cruelty' in a different, positive sense, as distinct from perversion, and in opposition to the notion of torture. Firstly, I take my cue in this respect from practices of punishment in maritime law, which can hardly be defined as only 'harsh'; they were cruel. One of the simplest and relatively frequent forms of punishment, for instance, was piercing a man's hand with a knife and drilling it in the mast (NB the knife was small and did not pierce the hand through the bones). The person punished was the only one allowed to draw it out. This was certainly cruel. Yet, it would only have become torture if the person had been pinned to the mast again after having freed himself. Having drawn himself free, the one punished had had enough. Secondly, my more conceptual cue in relation to the definition of cruelty is taken from Gilles Deleuze, who distinguished between torture and cruelty by linking the former to a culturally and legally framed system of guilt, and the latter to an ecological system of combat. It is a notion he emphasized to counter the idea that there could be justice without it. For Deleuze, as James Williams explained, 'difference as chaos is necessary and compels acts of determination to a necessary cruelty. His precise understanding of cruelty is, then, the generation of emotion and change as things are determined in relation to an indifferent background. ${ }^{162}$ The Deleuzian point, here, is that one should not think that a system of justice free of God's sovereignty and its logic of torture could be free of violence and pain. On the contrary, it would need to be based on the cruelty of combat. Here as well, my argument is historically anchored and connects not only to the practical way in which order on ships had to be maintained but also to the praxis of seventeenth-century state formation and the role of subjects and subjection, or of freedom, in that formation.

16o Daniel Baraz, Medieval Cruelty, p. 179; quoted in Yamamoto-Wilson, Pain, Pleasure and Perversity, p. 117 .

161 Yamamoto-Wilson, Pain, Pleasure and Perversity, p. 13.

162 James Williams, Gilles Deleuze's Difference and Repetition, p. 63. 


\subsection{Combat, the dramatic logic of cruelty, and the potential of difference}

If the Verschuier's painting is considered within the frame of one world, it could be an example of what was called at the time 'a pleasant spectacle' that made those who were saved enjoy what happened to the damned. The phrase was derived from Aquinas' answer to Quaestio 94 ('The relations of the saints towards the damned') of the supplement to the third part of the Summa Theologica from 1265. There, Aquinas argued, basing himself on quotes from the Bible, that the blessed had every reason to rejoice in God's will, according to which the damned should eternally suffer. ${ }^{163}$ If Kievit was the one who ordered the painting, he was surely happy that the brothers De Witt had been eliminated, but not in the context of the one world in which the saved should be separated from the damned. At stake was combat, in the sense of a political and spectacular confrontation with winners and losers. In that context, the painting could be read as a specimen of the violentiae theatrum; it showed a public execution in a spectacular way and repeated it, theatrically. At the same time, as said, the painting brings us to an un-representable, dramatic moment. Such a moment would and could not follow the logic of torture. It would have to follow the logic of cruelty in the sense I have described above.

Considered in terms of everyday reality and practice, the logic followed on ships was not one of theological guilt but one of Deleuzian combat. The same held, so I want to argue, for the way in which the brothers De Witt were killed. The collective response to the murder of the De Witts has been historically framed by a public debate, the so-called Wittenoorlog, ('War of De Witts') almost a century later, in 1757. The debate between republicans and Orangists found an anchor point at the time in a text by Joachim Oudaen, who had been in The Hague on the day of the murder: Brother Murder in the Hague or MadJoy; a tragedy (Haagsche broeder-moord of dolle blydschap; treurspel). In the play, written in 1673 but only published in 1712, the murder, public dissection, and display of the bodies is described in detail to the father and sister of the brothers De Witt. The theatrical representation and ekphrasis proved to be rhetorically effective in later years. It served then as the theatrical repetition of a complaint. As such this later restaging forms a counterpoint to the Verschuier painting in which the lynching is dramatically re-enacted.

163 On this see Yamamoto-Wilson, Pain, Pleasure and Perversity, pp. 155-156. 
Oudaen's theatrical reconsideration in the eighteenth century would become an important historical representation of the case, not only in the 'War of De Witts', but up until this day, as is expressed in a recent study by Prud'homme van Reine. ${ }^{164}$ Still, that very same study shows how the murder of the brothers De Witt was a straightforward matter of state formation. Immediately after the lynching a fierce debate evolved, predominantly making use of pamphlets. From a contemporary view it is easy to understand those who were revolted by the lynching and we might easily miss, or shun away from, responses at the time that were far from concerned with the injustice of what had happened, as the previously mentioned study by Michel Reinders has made clear. Just one example is Jan Zoet's poem D'Ydele vlugtvertoont in de schielikke dood van Kornelis en Jan de Wit (The vain escape shown in the quick death of Kornelis and Jan de Witt'). ${ }^{165}$ It serves to show how many considered what had happened to the brothers to be just. A strong example is an anonymous street song entitled De verhemelde geest ('The ghost that went to heaven') which sings the praise of Buat, who had been accused of high treason and executed under the brothers De Witt. This song of praise is followed by 'Seven questions with regard to the two Witts' death / executed to save the land from having its last breath' ${ }^{166}$ These may serve to show how the different forms of logic were operative at the same time: logics of the theatrical and the dramatic, and logics of theologically underpinned guilt and torture and of practically, cruelly performed combat.

This is how the questions unfold (and note that I had to alter the original slightly to let it work as powerfully as the densely rhyming street song):

1. Why did a Musquet kill the brother De Witt, Because they had changed church liturgy by writ,

2. Why were they tied up with pieces of fuse?

Because of the eternal Edict that was their ruse.

3. Why were they not tied up with rope, by chance?

Because they wanted to murder the prince of Orange.

164 Ronald Prud'homme van Reine, Moordenaars van Jan de Witt.

165 On this see Rudolf Cordes, Jan Zoet, Amsterdammer 1609-1674, pp. 581-588.

166 In the original: 'Seven vragen aengaende de twee Witten haer doodt / Geschiet om 't Landt te redden uyt sijn groote noot'. 
4. Why their members dispersed to all sides without fuss?

Because their way of ruling had been thus.

5 . Why were their hearts cut out of their bodies?

To investigate their deep hypocrisies.

106 . Why were they put up high on a scaffold?

To show everybody the justice of God.

7. Why were they, by verdict, not declared free?

Because killing Buat and Van de Graef by verdict was their idea. ${ }^{167}$

Overall, the questions and answers are undeniably straightforward and realistic. Yet, the justification of the dramatic cruelty differs from the theologically framed, theatrical display that is introduced with question 6. All the other questions and answers are not theatrical in nature. They concern the way in which the De Witts were killed, why they were tied up with one material and not the other, why their members had been spread, how their bodies had not been given free-all practical matters. They were dealt with cruelly, so this text states, but this was a cruelty in response to cruelty, neither perverse nor unjust.

It is not surprising, then, that despite the societal debate, William III was able to silence controversy over the matter. The murder was not investigated; the suspects were not prosecuted. William advised the States to let the matter rest, and a general amnesty was the result. The political combat at stake, between the quasi-royal stadholders of Orange and those who favored the political and republican dominance of the States, was intrinsic to the Republic. Both parties tried to frame and justify their positions theatrically. That said, there was no escaping the dramatic moments in which political choices between incompatible worlds determined the course of history.

${ }_{167}$ 'De verhemelde geest van den doorluchtigen Oranje-martelaer Henry de Fleury', 1672, http:// www.dbnl.org/tekst/_vero15verho1_01/_vero15verho1_01_0002.php. In the original: '1. Waerom zijn beyde de Witten gesnuevelt door't Musquet, / Om datse verandert hebben het kercke gebedt, 2. Waerom wierdense met eynde van Lonte gebonden? / Om datse het eeuwigh Edict hebben uytgevonden. 3. Waerom sijnse niet gebonden met touwen? / Om datse de Prins van Orange vermoorden wouwen. 4. Waerom sijn haer Leden soo over al verdeelt? / Om datse over al soo het heerschap hebben gespeelt. 5. Waerom sijn haer de Herten uyt het Lijf gesneden? / Om 't ondersoecken haer diepe geveynsdigheden. 6. Waerom sijnse verhoogt op het Schavot? / Om yder te thoonen 't rechtveerdigh oordeel van Godt. 7. Waerom sijnse volgens Sententie met vry gegeven? / Om dat Buat en van de Graef by Sententie deê benemen 't leven.' Note that there is a mistake in the dbnl version. The 'met' in strophe 7 should be 'niet'. 
In this context Deleuze's definition of combat and cruelty is of relevance. Such cruelty is distinctly different from the atrocities that took place throughout Europe in the fierce conflicts of the sixteenth and seventeenth centuries. It is also distinctly different from the pain inflicted upon martyrs, whether by others or themselves. It should be understood in light of the chaotic issue of state-building, and, by consequence, in light of the form of justice realized by a state and in it. For, even when in calm waters, a state is never beyond chaos; the original chaos is simply territorialized. Ideally, then, there has to be a balance of terror in the state's territorialized domain; a balance, as lawyer Robert Cover once put it, between criminal acts of violence and the state's acts of violence. In republican terms it would be a balance without a transcendent ground, but an immanent one, based on cruelty, yet understandable and justifiable.

Through its complex mixture of the spectacular, the theatrical, and the dramatic, Verschuier's painting can be seen in baroque terms. It depicts, by connotation, something that effectively foreclosed the Dutch republican baroque. William III would not just be quasi-royal but would become a real king, of England, in 1689. A certain baroque spirit still circulated there, but in the familiar context of princely, or royal, centralized rule, something that is exemplified by the rebuilding of Hampton Court. In order to firmly establish this court, this rule, and this princely baroque, another world had been cruelly eliminated.

Yet, cruel elimination is not the only dynamic that leads from a plurality of worlds to the realization of one. Let me move to a happier note in the next chapter on the work of Frans Hals. 


\section{A happy split of worlds or the comedic sublime - Frans Hals}

\subsection{Happiness, the comedic, and the sublime}

In the work of Frans Hals (1582-1666), people laugh, abundantly. Yet, all these artfully, convincingly represented laughing people are not effective in making us laugh, as would be the case in different genres of the comic or the comical. In that context Hals' laughing faces would have been 'comic prompts'. ${ }^{168}$ Yet they are not, so what did, and do they do? The answer to this question can be sensed and tested by revisiting one of Hals' more famous paintings: Young man and woman in an inn, from 1623, formerly known as Jonker Ramp and his sweetheart (see figure 9). Of late we have seen a shift in the scholarly analysis of works such as this; a shift that can be specified as a turn away from a moralizing-didactic approach and toward a festive or celebratory one, which affects the audience rather than teaching them something. ${ }^{169}$ The scholarly attraction of the moralizing approach is that it can specify so easily, or so it seems, what paintings mean. Even in some of the studies that acknowledge the festive and celebrating character of seventeenth-century Dutch art, one can trace the powerful echo of what most nineteenth and twentieth-century scholars would contend: that it always carried, even if ambiguously, a moralizing message. For instance, Barbara Haeger's paradigmatic reading of this painting by Hals held that it did not depict the prodigal son - a contention brought forward by othersbut carried the message that the world can be enjoyed only if we restrict our passions, avoid frivolous places and company, and shun especially the excessive use of alcohol. ${ }^{170}$ Likewise, Gerlinde Lütke Notarp, in her study on the iconography of tempers in the sixteenth and seventeenth century,

168 On the comic and comical see, for instance, René van Stipriaan, Leugens en vermaak; Mariët Westermann, Amusements ofJan Steen, or Noël Schiller, “'To see ourselves greatly misled"'. The latter two also focus on the laughing face as comic prompt.

169 Anna Tummers, ed., De Gouden Eeuw viertfeest; translated as Celebrating in the Golden Age. Studies that contributed to the shift from moralism to celebration are: H.Rodney Nevitt, Art and the Culture of Love in Seventeenth Century Holland; Elmer Kolfin, The Young Gentry at Play; Noël Schiller, 'The Art of Laughter'; and Thijs Weststeijn, 'Een feest voor het oog'.

170 Barbara Haeger, 'Frans Hals so-called Jonker Ramp and his sweetheart reconsidered'. For a comparable regular moralizing reading see also Christopher D.M. Atkins, The Signature Style ofFrans Hals, p. 259, where Atkins mentions the sixteenth-century Jan Sanders van Hemessen as Hals' moralizing paradigm for this painting. 
noted that despite all the joy and exuberance, in the end such iconography is only meant to moralize and warn the audience against excess. ${ }^{171}$

I find these moralizing readings, when presented as the end result of any meaning-making process, unconvincing. They are so, firstly, for historical reasons, as has been brought forward in Anna Tummers' catalogue, Celebrating in the Golden Age, in an evident response also to the powerful echoes of Simon Schama's The Embarrassment of Riches from $1987 \cdot{ }^{172}$ If the pubs and brothels had truly been only morally objectionable, they would not have been represented in such numbers and with such apparent joy. Moreover, people were far from embarrassed in celebrating life, as the festive culture in private houses, gardens, and public spaces testifies to. All this existed as abundantly as the laughing faces in the work of Hals. Contemporary views on the seventeenth-century Republic may still be suffering, here, from a moralizing approach that is more indebted to the nineteenth century than it is an adequate engagement with the seventeenth. In his studies on laughter and humor in Dutch society, Rudolf Dekker has convincingly shown how in the seventeenth century a battle was being waged between those who loved jokes and joking and those who could not stop moralizing. At the end of the seventeenth century this battle was won by the moralists for coming centuries. ${ }^{173}$

Secondly, there are formal reasons why a moralizing reading of this specific painting is not convincing. They concern the painting's focus of attention, which is not the glass that the man is carrying. The way in which this composition directs the viewer's attention has been studied mostly in terms of 'a young man raising his glass' ${ }^{174}$ The young man is clearly looking upward diagonally. Yet, this is emphasized by visually rhyming patterns. There are several straight lines that point in the same direction: one running from the dog's face and the man's left arm, via the diagonal fold in his jacket, to the right arm; one from the cuff on the left arm of the woman; one from the face of the man in the back to whatever it is that the man in the front is pointing at; and one from the ribs in the ceiling that are directed to that very same spot. Finally, there is the curved line of the feather, with the left part again turning upward diagonally. Especially the ribs in the ceiling formally emphasize that the face of the man at the back

171 Gerlinde Lütke Notarp, Von Heiterkeit, Zorn, Schwermut und Lethargie, p. 117.

172 Simon Schama, The Embarrassment of Riches.

173 Rudolf Dekker, Lachen in de Gouden Eeuw; or by the same author 'Hard gelach in de Gouden Eeuw'. On laughter in daily life, see also Johan Verberckmoes, Schertsen, schimpen en schateren. 174 See, for instance, Metropolitan Museum of Art, Europe in the Age of Monarchy, p. 77. 
is neither directed nor looking at the glass that the man holds in his hand. This suggests that the man in the front is also looking at something beyond the glass, to which he raises it. This man raises the glass, then, to something that lies outside of the frame of the painting and the scope of the viewer. He is looking at something we have to guess at, to sense, because it is in the realm of the unexpressed - or perhaps because it belongs to the realm of the inexpressible. The laugh on the face of the woman looking directly toward us does not inform us in detail about what the man is laughing about, but it does dramatically translate to the viewer that which the man addresses.

When Karel van Mander indicated in his Schilderboeck that it is incredibly difficult to catch the difference between laughter and sobbing in paint, he might have mentioned that the true master of laughter was (his pupil) Frans Hals. ${ }^{175}$ Indeed, the latter's exceptional skill allowed him to represent happy people in a happy world in such a way that they affect us (as would be the point of Rudolf Dekker or, earlier, of Seymour Slive). ${ }^{176}$ Still, this painterly skill cannot explain how the painting radiates an affective power that makes one ask what the man and woman are laughing about, or perhaps better, $a t$, and what the intensity of their laughter consists of or hints at. Though they have clearly been drinking, neither the man nor the woman are drunkards. Yet, their laughter appears somewhat disproportionate, or appears to be an expression of defiance that, in my reading, turns this into a sublime painting or a painting depicting a sublime moment.

The nature of this type of the sublime should relate intrinsically, then, to laughter - or better, to almost unrestrained happiness. Now, the relation between the sublime and the comic has never been fully theoretically developed. In Longinus' treatise on the sublime the subject of laughter is mentioned at times, but never developed, and since then laughter and the sublime seem awkward partners. Yet, if in the work of Hals the two appear to be brought together, his work provokes the question of how the sublime is related, formally and in terms of content, to happiness and the comic. Such a question would not concern the work of Hals only. Within the context of the baroque nature of the Dutch Republic, the sublime and the comic could be considered more generally, or they should be so. In the baroque world of the Dutch Republic there was an abundance of the comic, expressed in a variety of comical genres and a variety of mediums. More importantly,

175 Van Mander calls it, in his fourth chapter on the depiction of passions, the difference between 'het lachen en 't crijten', l. 32; Karel van Mander, Het schilder-boeck, see: http://www. dbnl.org/tekst/mandoo1schio1_01/ 176 Seymour Slive, Frans Hals, Volume 3. 
however, in relation to the sublime, I would argue that a religious, medieval or Renaissance meaning of comedy was given a worldly equivalent in the Dutch baroque.

The medieval or Renaissance form of religious comedy finds a paradigm in Dante's Divina Comedia, a text that was far from a straightforward matter of laughter. Although it may have caused audiences to laugh, especially in the first part, this would have been something that I will come to define in terms of the ridiculous. In the latter parts of Dante's Comedia, however, delight would follow, up until the point of the inexpressible joy of the sublime. Dante's comedy sketched-contrary to tragedy—a trajectory from bad to good, from hell to paradise. As such this form of comedy would not be analogous to the abundantly produced comical, celebratory, literary, theatrical, and pictorial expressions of laughter in the Republic, and for two reasons: ${ }^{177}$ these comical pieces were hardly ever religious, and they were not 'comedic' in sketching a trajectory from bad to good.

Still, Dante's comedy may help us to find a way of considering the sublime in relation to the happiness captured in Hals' work. With Dante, comedy consisted in the ultimately happy inclusion of one world in another, of the earthly one in a divine one. In the medieval and Renaissance worldview the two worlds were not principally separate. Following the logic of Neoplatonism, the earthly world was a lesser emanation from the heavenly one and could therefore be included in it. Such a possibility of Neoplatonic inclusion was countered, in the seventeenth century, by the idea that there are several possible and real worlds that can, momentarily, coincide but that are principally separate. This was worked out philosophically by Spinoza first, Leibniz later, but also in some works of art, as Thijs Weststeijn has argued. ${ }^{178}$ Part of the Dutch baroque sensibility consisted of the realization that reality is multiple and momentous under the aspect of 'creation'. That is to say, this world is neither finished, nor predestined, nor framed; it is one out of many possibilities and, as such, creative in nature.

In terms of 'creation', the sublime operative in Hals' work can be considered as a form of comedy that is comparable to Dante's while at the same time being radically different from it. Hals' comedic sublime is worldly in that it relates to the actualization of a happy world as opposed to other, more gruesome, ones. All are equally real, intrinsically linked at some point or moment, after which they split off and become disparate, separate realities. From that moment on they are only palpable in a sublime way, as

177 On this see Mariët Westermann, Amusements ofJan Steen.

178 Thijs Weststeijn, The Visible World, pp. 346-349. 
existent by implication. The 'comedy-like' sublime that is bound up with this palpability, I will call comedic from now onward in order to distinguish it from the comic and the comical. It works by showing how the overwhelming power of the sublime is not acted out upon the human subject, but has a source in that subject's relation to a world lucky enough to be actualized among other possibilities. In this light, and simply put, the young man on Hals' painting shouts 'Ha!' to another, gruesome world that was oh so close to becoming real, but was split off.

To avoid any misunderstanding, in what follows my use of the term 'sublime' will partly follow Early Modern Dutch conceptualizations - in, for example, the works of Heinsius and, to a lesser extent, Vossius - in which the sublime was predominantly defined by its overwhelming element. But would that have to be an element found only in art, or could it also be an element of everyday reality? Or could it be an element of art in its relation to everyday reality? In what follows, I ask these questions in the context of what is not simply 'the' baroque but this distinctly Dutch republican baroque, for which I consider the work of Hals to be paradigmatic. However, let me first consider a work of Jan Steen to make a sharper distinction between the comical and the comedic, and let me bring in the work of Joost van den Vondel to make a sharp distinction between the possibly comedic and the tragic natures of history. Hals' relation to these two figures will lay the groundwork for a more detailed exploration of why Hals' work is an example of the comedic sublime, and in this sense paradigmatic for the republican baroque.

\subsection{From Steen to Vondel: comical and tragic counterpoints to the comedic}

One of the earliest baroque theoreticians in North Western Europe is Philip Sidney who, in his Defense of poesy from 1579, distinguishes between delight and simple laughter. He comes to define these in relation to scorn as the ridiculous, and then to distinguish between the ridiculous and laughter about 'sinful things':

Delight hath a joy in it, either permanent or present. Laughter has only a scornful tickling. ${ }^{179}$ 
And a little later:

All the end of the comical part be not upon such scornful matters as stirreth laughter only, but, mix it with that delightful teaching which is the end of poesy. And the great fault even in that point of laughter, and forbidden plainly by Aristotle, is that they stir laughter in sinful things, which are rather to be execrable than ridiculous; or in miserable, which are rather to be pitied than scorned. ${ }^{180}$

Sidney's treatise and these distinctions are useful in reading many of Jan Steen's paintings. In general, one could argue, these paintings tend towards the delightful in that they want to teach something joyfully. Yet, there are also Steen paintings that tend towards the ridiculous, in terms of scorn, or they verge on laughing at what is sinful. In fact, in spite of Aristotelian requirements, it seems that Steen took every opportunity to use the ridiculous, or the execrable, his works often bringing their audiences to laugh about others and their silly or sinful behavior.

A good case in point is Gamblers quarreling, from 1665, now in The Institute of Arts, Detroit. The modern reader can find the ridiculous and the sinful in close (digital) detail on the institute's website, thanks to modern technology (see figure 10). ${ }^{181}$ Here, there is no palpable tension between two intrinsically connected but separate worlds. This is the world of the pub, with its games, drinks, prostitutes, and jolly meetings, and the audience is invited to laugh, just as the three men in the back are doing. If one is to laugh about what one sees, this is clearly to ridicule it. The ridiculous is linked to its etymological origin, here, of 'joking', which in turn goes back to the Latin iocus, game or pastime, and by consequence jest. For Sidney, the ridiculous is related to scorn in that one is not laughing with, but about, and that someone is treated with scorn or derision by implication. Laughter could even topple over into the wrong kind of laughter here, when people laugh about matters that are not laughable at all, such as when someone draws a sword to kill in rage (as the figure on the right is doing) or when nuns are joining in with drunkards (as appears to be the case in the center). Here laughter would have to fall silent if we consider what is poor and hateful in terms of the execrable, as Sidney suggested.

180 Sidney, An Apology for Poetry, p. 151.

181 One can use a digital magnifying glass that amplifies any chosen part of the painting; see:http://www.dia.org/object-info/cb7c827f-15b6-47b4-a027-08578317272d.aspx?position=138, accessed August 2014 . 
Still, I doubt very much whether Steen would have agreed here with Sidney. In the case of this painting we had better take seriously that the three in the back are laughing, and will keep on laughing, even if the man drawing his sword were to act out his rage. To them the nun trying to control her drunken companion is not an issue of sin. Both are part of the game. In fact, the company at the back may be seen as jeering, goading one man to kill the other, goading the nun to order another. In this context, Steen is distinctly not baroque or sublime in the sense of the comedic. He is joking, as Rudolf Dekker would argue, or he is comical, as Mariët Westermann has shown in her study of Jan Steen's work in the context of seventeenth-century comic painting. ${ }^{182} \mathrm{He}$ might even be farcical and provoking laughter where others would fall silent. He remains in and belongs to the everyday world that he depicts so intimately because he takes part in it. ${ }^{183}$ This is not to say that Frans Hals, in contrast, did not partake in the world of the pub. But even when he uses scenes from it, they are not comical but comedic.

The latter term, comedic, is exemplified in a painting by Hals entitled Laughing fisherboy, now in Schloss Burgsteinfurt (see figure 11). ${ }^{184}$ Here, too, we see someone laughing. Yet, the painting does not make us laugh. So, again, what does it do? It is moving, literally and figuratively, and as a result clearly moves us. This affect, as Thijs Weststeijn suggested, was central to seventeenth-century Dutch practices and theories of art. ${ }^{185}$ Behind the boy we see the forces of nature in the white clouds amassing; it is as if the movement of the boy to the left is countered by the clouds amassing to the right. The boy is standing with his back toward this overwhelming force or nature. Any fisherboy would know that the weather can change rapidly. A small dark area behind the big white cloud on the right may even suggest that a thunderstorm is building. As it is, however, the world is happy, and the enormous powers of the clouds do not impress the human subject standing in front of them, but instead enforce his powers and ability to be in this world. In effect, the comedic embodied in and expressed by this painting

182 Rudolf Dekker, Lachen in de Gouden Eeuw and Mariët Westermann, Amusements of Jan Steen.

183 On the way in which the painters and writers who depicted pub scenes and festivities were supposed to be taking part in them, in order to become experts on the topic, see Anna Tummer, Celebrating in the Golden Age, and Thijs Weststeijn, 'Een feest voor het oog'.

184 In the eyes of Numa S. Trivas many fisherman paintings attributed to Hals were not to be; see his The Paintings of Frans Hals. Seymour Slive and C.A. van Hees argued differently in the catalogue to the Frans Hals exhibition in 1962; see also Seymour Slive and Peter Biesboer, Frans Hals. Since then the painting has been officially acknowledged as made by Hals.

185 Thijs Weststeijn, 'Between mind and body'. 
affects the audience in that, instead of reducing the spectator's power, or humbling his or her status, it enhances the spectator's powers, heightening his or her body's capacity to act, as Spinoza would say. Captured in the specificity of this world, the comedic acknowledges that life both can be made different and could have been so different.

The comedic is an obvious counterpart, here, to the tragic, so crucial to another baroque icon in the Dutch Republic: Joost van den Vondel. In a letter to Hugo Grotius dated 9 September 1639 (already mentioned in chapter 2), Vondel confessed that, after one and a half decades of attempts and despite promises, he had stopped working on a major epic work. This is what he wrote:

I am offering Your Excellency what lies in my power, not what I would want. Since the death of my beloved wife my energies have gotten a blow so that I will have to forget my great Constantine and to make do with something smaller. [...] If I have grown tired of writing tragedies, I will see whether I will get back to my Constantine; meanwhile I ask Your Excellency to accept this for what it is, until we find the strength for bigger things. ${ }^{186}$

To say that Grotius was Vondel's close friend would perhaps be an exaggeration, but the two had remained in close contact, also via Grotius' wife, ever since Grotius became one of the political casualties in the process instigated by stadholder Maurits against Oldenbarnevelt. Since his imprisonment in the castle of Loevestein and his crafty escape, Grotius had fled the country, returning in 1631, but officially banned for the rest of his life after $163^{2}$.

Vondel's alliance with and loyalty to Grotius is interesting, in relation to the simultaneous existence of worlds, for two reasons. The first one is that the situation in the Republic was so politically charged because it embodied the split between a monarchical and republican way of organizing the world. Taking sides with Grotius implied that Vondel was opting for the republican world and was bound to have a complicated relation with members of the House of Orange. He certainly never forgave Maurits for having killed Oldenbarnevelt; his relationship with Frederick Henry was

186 Hugo Grotius, Briefwisseling van Hugo Grotius. Deel 1o, p. 582 . In the original: 'Ick offer uwe Extie 'tgeen ick vermagh en niet het geen ick wel soude willen. Zedert de dood van myn zalige huisvrouwe heeft myn couragie eenen krack gekregen, zoodat ick mynen grooten Constantyn moet vergeten, en met yet minders my zoecken te behelpen. [...] Als ick myn lust in treurspelen hebbe geboet, magh ick zien, of ick weder aen mynen Constantyn valle: middelerwyl gelieve uwe Exctie dit voor lief te nemen, tot dat wy yet grooters vermogen.' 
ambivalent. After having glorified the birth of William II, Vondel called him a Lucifer when the latter tried to occupy Amsterdam in 1650, and Vondel welcomed his untimely death. Had he not stopped writing because of old age he probably would have taken up his pen in rage in 1672 , the year that announced the rise of a monarchical William III after the brutally organized lynching of republican icons: the brothers De Witt. The second reason is more pertinent and concerns the very nature of making history. Grotius had suggested to Vondel that he should write an epic on the Roman emperor Constantine who was at the basis of a unified religio-political European order. Grotius was looking for an artistic underpinning, here, of his efforts to restore the fundaments of the one and only Church that would bring an end to a Europe ripped apart by religious strife and sectarianism. ${ }^{187}$ Vondel supported this endeavor. He had been thinking about his work on Constantine and writing parts of it since 1623. By 1634, he had completed five songs, yet finally stopped his work, sixteen years after starting it.

Stopped it? Destroyed it.

Joachim Oudaen, who at points was an opponent of Vondel but nevertheless admired him as a poet, suggested to Vondel's biographer, Gerard Brandt, that the reason for this desctruction was that Vondel had come to realize what an odd Christian hero Constantine was. The latter had murdered his son Crispus (who was in his early twenties) first, and his second wife Fausta a little later (she was suffocated in a much-too-hot bath). The reason was that they were said to have had a sexual relationship. ${ }^{188}$ Yet, the sexual relation between stepmother and son, which sources suggested that Fausta had set up, would have fascinated Vondel. Real history resonated explicitly, here, with the stories of Hippolytus and Joseph, also stories about powerful women (one being a stepmother) declaring their love to a resistant or afraid, but in any case innocent, young man. Vondel wrote no less than four plays on the theme (in 1628, 1635, and two in the year that followed the Grotius letter, 1640). ${ }^{189}$ The tragedies worked with three basic forces, familiar to all early

187 On this see Henk Nellen, Hugo Grotius, a lifelong struggle for peace in church and state, $1583-1645$.

188 Major sources for this history were Byzantine chroniclers: the 5 th century author Zosimus with New History, ('I $\sigma \tau \rho \rho^{\prime} \alpha$ N $\varepsilon \alpha$ ), and the 12th century author John Zonaras, with Extracts of

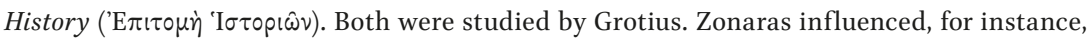
Grotius' early work on the relation between state and church, written between 1614 and 1617, On the Power of the Sovereign in Ecclesiastical Affairs; see Grotius, De imperio summarum potestatum circa sacrum, p. 118. Zosimus appears as a source in, for example, Grotius' The Rights of War and Peace, p. 229; and in his Meletius or Letter on the Points of Agreement Between Christians.

189 In 1628 he translated a Senecan play entitled Hippolytvs of Rampsalige kuyscheyd (Hippolytus or disastrous chastity), in 1635 he made a translation of a Latin play by Grotius himself: Hvigh 
modern drama, that determined the making of history: that people were driven by uncontrollable passions, that history could consist of sequences of contingent events and mistakes, and that consequently a happy outcome of history was possible, but not likely. In this light, Constantine's killing his (innocent) son might have been a gross mistake, and an unforgivable one. As a consequence, he hardly embodied the unity and coherence of history but instead emphasized its being driven by passion, highlighted its contingency, or even fragmentation, and thus suggested that the world could have been otherwise.

Connected to the issue of history's unity, Vondel faced a generic problem as well. Theoretically speaking, epic was still considered the most eminent serious genre at the time (the authority here was, as always, Vossius). ${ }^{190}$ Yet Vondel struggled with it. In my reading, this was because of epic's narrative ordering, its necessary logico-chronological sequence of events, and the required narrative closure, in short because of its classicist linearity. Vondel did write an epic, and in that sense narrative, piece with Johannes boetgezant (John Baptist). However, this epic came close to the vast Bespiegelingen van Godt en Godtsdienst (Reflections on God and Religion) from the very same year, 1662, which was less an epic than a treatise. In the end, formally or aesthetically speaking, narrative too closely resembled the organization of history through predestination, which was a major and even dominant target of criticism in Vondel's work. He was fundamentally a playwright. He was so artistically, in terms of capabilities and inclinations, but more importantly and more baroquely, he was a playwright conceptually, in relation to history's dramatic open-ness - or better, in relation to history's interruptibility, which was in turn related to the intensity of a moment.

\subsection{The sublime intensity of the moment}

As was mentioned in the beginning, Young man and woman in an inn had mostly been considered a depiction of the prodigal son in his exuberant and sinful life before his downfall and subsequent return home. Such a reading of the painting fits with the logic of our living in one, predestined

de Groots Iosef of Sofompaneas (Hugo Grotius' Joseph or Sofompaneas) in 1640, finally, Vondel wrote Joseph in Dothan, and Joseph in Egypt.

190 On this see Vossius, Poeticarum institutionum libri tres, and Marijke Spies, 'Het epos in de 17e eeuw in Nederland', where she points out that Vossius' most explicit ideas on epic had been brought forward in his De artis poeticae natura ac constitutione liber. Amsterdam 1647, cap. VI, par. 5 , pp. 32-33. 
and prefigured world. That Hals follows another kind of logic is evidenced by Young man with a skull, from around 1626 , now in the National Gallery, London (see figure 12). When Seymor Slive contended that the young man depicted could not be Hamlet, as argued by Hofstede de Groot, since there were no English companies travelling through the Netherlands before or in the 1620 s, he was simply wrong. ${ }^{191}$ Pieter J. J. van Thiel would argue that the man depicted could not be Hamlet because he is not wearing contemporary court clothes and because it is not established that Hals ever saw a performance of the play. ${ }^{192}$ Nor would he have needed to; he could simply have heard of it in a culture with a vast theatrical awareness or repertoire, built and rebuilt dramatically and collectively on the basis of what people had heard (see chapter 7). When Van Thiel, like Slive, comes up with the seemingly evident solution that this must be a Vanitas, he conveniently skips the fact that in most similar so-called Vanitas paintings, the man (it is mostly a man) holding the skull is looking the viewer in the eye. Not so in this case: the healthy young man holding the skull is extending his hand-a hand painted before a cloak that is layered in many folds - toward the viewer. He is holding the skull, lightly, looking in the very direction which the skull's empty sockets are pointed. Because of the way in which the hand holds the skull, it is as if the upper part is indeed a skull, but the lower part a fleshy chin and throat. With the feather dropping downward, a square is formed that leads the viewer's eye in a clockwise direction, with the hand in between the skull and the face. Through this movement, the young man's hand becomes like a tremor between two possibilities: life or death-'to be or not to be'. Protecting him against the possibility of the end, of death, there is the harness of the folded cloth in front of him. His eyes show that they know what is at stake, at this very moment. His face is one of the most complex that Hals ever painted: no exuberance here, and no drinking. Yet the eyes of the young man almost appear to restrain themselves in order not to be exuberant about life or defiant toward death. And even if this is not the case, this is certainly not a gloomy, melancholy, or otherwise especially troubled young man. It is a young man being aware, in a dramatic moment that, as such, is open.

Likewise, to Vondel, drama — not theater, but drama—offered the possibility of enacting, re-enacting, and thereby regenerating choice in relation to the charged moment. Drama was the best generic form to present choices,

191 On this, see Douglas A. Brooks, Ton Hoenselaars and Holger Klein, eds., Shakespeare and the Low Countries. For Slive's argument, see Frans Hals, vol. 1, pp. 88-89, or vol. 3, pp. 37-38. 192 Pieter J.J. van Thiel, 'Moeyaert and Bredero', p. 29. 
in their dramatic reality and potential, between two equally real worlds. The dramatic pivoted on the fact that choices would have to lead to one out of a set of possible worlds. And, tragically, people tended to make the wrong choices more often than not. The element of choice was pivotal, then, to Vondel. With regard to this, even when his tragedies complied with Aristotelian requirements, they remained, in one way, distinctly non-Aristotelian: they reduced the importance of plot while increasing the importance of interruption. ${ }^{193}$ Yet he was distinctly Aristotelian with respect to the distinctive moments in the play. The peripeteia, the moment of reversal, or the anagnorisis, or agnitio, the moment of sudden insight, could function as breaks in the plot structure that opened it up. Paradoxically, this may also explain why Vondel's plays favor (at times lengthy) argumentation above action. Actions, driven by plot, enforce choices or result from choices. Arguments, by contrast, test choices or make them possible. Vondel's characters are not caught in plots; they are enwrapped in arguments, wrestling with them in a distinctly baroque way. I call these bouts of wrestling baroque especially because of the narratives that encircle them, are folded into them, and escape from them. In contrast with Benjamin's analysis of the German Traurspiel, Vondel's world is not a world of fragments but of Deleuzian folds. ${ }^{194}$

It is not an exaggeration to state that what happened in the Republic fascinated and exhilarated many, as the paintings by Hals show us. But it also frightened many. One deep fear, perhaps even a primal one, is described in a study by Gerard Brom from 1935 entitled Vondel's geloof (Vondel's Belief). For Vondel, the correct historical order of things was captured by the threefold sequence of God-Jesus-Church. God created the world and mankind, then sent his son Jesus Christ to free mankind from its imprisonment through and after the Fall, as a result of which the one and only Church could come into existence. The shocking reversal witnessed by Vondel, Brom argues, not just implied but actualized another history and world. It was one in which Luther had blown apart the one and only Church, in which the Sozzini duo and the resulting Socinianism denied the divinity of Jesus, and in which the radical consequence had to be that God did not exist as the creator of this one world. This would indeed be the powerful conclusion proposed by

193 Interruption (also see chapter sections 8.1 and 8.2) is used here in a sense radically different from the one proposed by Octavio Paz. In the baroque, interruption disrupts history as it seemed to be unfolding, like Paul being struck on his way to Damascus, whereas for Paz interruption is the modern tendency to constantly conflate past, present, and future. On this reading of Paz, see Gregg Lambert, The Return of the Baroque in Modern Culture.

194 I am referring here to Deleuze's study on the work of Leibniz in Le pli, or The fold. 
Spinoza. ${ }^{195}$ It concerned a dramatic reversal much more than an unbalancing of the scales of history, because this reversal implied the possibility of different, possible, and coexisting worlds.

At this point it is pivotal to see how the coincidence of real worlds is dramatic, distinct from a collision of a real world with an imaginary one, and also different from defining the entire world theatrically. Even when in Young man with a skull we consider the young man a theatrical actor-playing Hamlet for instance-he is looking out of the scene to something else in a way analogous to Young man and woman in an inn. He is not piercing a theatrical fourth wall by confronting and addressing the viewer directly. Instead, his eyes suggest that, on the side, outside of the frame, there is 'something else'.

On art's potential to not just imitate one existing and real world but to also produce other imaginary ones, Philip Sidney had been explicit in his Defense of Poesy. In his thinking, poetry (and by extension art) was not imitative but, by means of imagination, was able to produce new worlds if the artist was able to use the zodiac of wit:

Only the poet, disdaining to be tied to any such subjection, lifted up with the vigor of his own invention, doth grow, in effect, into another nature, in making things either better than nature bringeth forth, or, quite anew, forms such as never were in nature, as the heroes, demi-gods, cyclops, chimeras, furies, and such like; so as he goeth hand in hand with nature, not enclosed within the narrow warrant of her gifts, but freely ranging within the zodiac of his own wit. Nature never set forth the earth in so rich tapestry as divers poets have done; neither with pleasant rivers, fruitful trees, sweet-smelling flowers, nor whatsoever else may make the too-much-loved earth more lovely; her world is brazen, the poets only deliver a golden. ${ }^{196}$

Art is able to produce worlds that extend beyond the given world, and artists have their own zodiac apart from the celestial one. Read through the lens of this quote, Hals can be a good example of this, in his own Dutch and worldly way. He does not so much project new utopian visions or imaginary figures, however, as he 'imagines' real figures, from everyday life, that embody the world's richness. Despite the ordinariness of his figures, he has 'the

195 Gerard Brom, Vondels geloof. On socinianism and the sense of a world falling apart, see Sarah Mortimer and John Robertson, eds., The Intellectual Consequences of Religious Heterodoxy. 196 Philip Sidney, An Apology for Poetry, pp. 83-84. 
God-like power to transform audiences, a power that is, in everything but name, creative'. ${ }^{197}$

Still, the transforming power of Hals' work suggests that there is something different in play than a matter of imagination. Artworks may project imaginary things beyond what we can see in nature, but as such, once in existence, artworks still introduce these imaginary things into this one world. The baroque dynamic that Hals is able to capture is more concerned with so-called counterfactuals, related to the momentous splitting of worlds that could both have been real for a split second and were then separated, irretrievably, but linger on in the form of a what-if. It is this 'what-if-ness' that is captured best by the young man's face in Young man with a skull. Here the comedic sublime works to capture the intense nature of the one world that is actualized and in which one finds oneself.

Two paintings hint at the surely extraordinary and in a sense even excessive intensity of moments and world in Amsterdam. The two were made around 1628 , and they present the same figure, although they have two different titles: The jolly reveller or Peeckelhaeringh, and Mulatto (see figures 13 and 14). These titles do not indicate a meaningful difference between the two paintings; they have been given in later years. Both paintings depict the same theatrical figure, as his costume shows. Both figure and costume have their source in English theater. ${ }^{198}$ Since 1618 the term peeckelhaering in Dutch has indicated a theatrical clown, a character that was not so much laughable (or ridiculous) but that provoked laughter. In the first decades of the seventeenth century, English theater companies touring the country had introduced this figure to Dutch audiences. Since then several farces had been made with a Peeckelhaering in the leading role, and he had been depicted in several paintings. ${ }^{199}$ Yet, the fact that there are two paintings of the same figure, also painted from opposite sides, suggests that we should perhaps not consider the paintings as only representing a theatrical character. The man, even in this costume, could also be someone we would encounter in the reality of everyday life, in one of Amsterdam's

197 Michael Mack, Sidney’s Poetic, p. 11.

198 On this see Ben Albach, 'Pekelharing: Personage en Potsenmaker', and Peg Katritzky, 'Pickelhering and Hamlet in Dutch art'.

199 Since 1618 Peeckelhaering has been almost synonymous with 'clown' (Te Winkel, Ontwikkelingsgang der Nederlandsche Letterkunde, p. 272). For another exemplary Peeckelhaering painting, see the one made by Judith Leyster (1629, Frans Hals Museum); Dirck Hals, Hendrick Gerritsz. Pot and Jan Steen also depicted him (Anna Tummers, De gouden eeuw viertfeest, p. 22). The figure's popularity can also be traced in the work of playwright Jan Zoet, see Rudolf Cordes, Jan Zoet, Amsterdammer 16o9-1674, pp. 64-70. 
pubs, in Amsterdam's harbor, as a member of the many commercial envoys visiting Amsterdam, or as someone taking part in theatrical, public, or private festivities. In its depiction of such a figure, so Noël Schiller argued, the painting would invite the viewers to become part of that reality. ${ }^{200}$

I suggest that through these two paintings we might be able to trace a typically Dutch republican baroque. Considered together, the two Peeckelhaering paintings do not so much address the thin line between theater and reality as they capture the baroque theatricality of Amsterdam's and the Republic's daily reality, which was the result of their dramatically actualizing a world. Witness to, and a material expression of, this joyful republican baroque style was the work of Frans Hals. In the context of a Dutch republican and therefore 'anomalous' baroque, Hals' work can be considered as initiating a complex oscillation between the sublime and the reality of the world, a world that is not only experienced more intensely, although this is surely the case, but also becomes intensified itself. In itself this would not be a reason to call Hals' work sublime. Such a form of the sublime would border on more familiar aesthetic strategies such as those indicated by terms like misto, or acutezza, in which contrasting styles or notions are brought together. Emanuele Tesauro, for instance, argued that this could be effected by means of antithetically activated metaphors. ${ }^{201}$ Yet, the collision of concern here is not metaphorical or allegorical. Hals' comedic sublime enacts a resonant collision between a real world and another, equally real possibility that did not materialize, and as such can only be sensed, indirectly.

\subsection{Freedom: necessity and contingency}

The baroque realization of the radical and turbulent divergences of worlds, and the dreamlike quality of the one actualized, should be sharply distinguished from the poet's or artist's capacity to imagine other worlds. Let me present one work as a final example of this: a painting that fairly soon after it had been made, was robbed of its baroque quality. A wine glass was painted over what had first been a weapon, and what had been wild, expressive hair was covered by an elegant beret (see figure 15). The result is telling in the context of my argument. This version has lost the dynamic tension in the sublime moment at which two radically different worlds meet. The original, 
entitled Portrait of a man with a cow's jawbone in his hand, also known as Verdonck, comes 'alive' because of the way the jawbone seems to be moving, as if being swung, and the hair on top of the man's head suggests that his head is moving forward in aggression (see figure 16). At the same time the relatively benign smile of the man suggests the opposite. As a result there is a contrast at play within the painting that brings us to the moment at which two intrinsically related possibilities are simultaneously real, though leading to separate worlds. Such a reading is a radicalization of considering this painting in terms of what at the time was known as acutezza, or wit.

Such acutezza was involved when an etching made of the painting by Jan van de Velde II was accompanied by an explanatory poem:

Dit is Verdonck, die stoute gast,

Wiens kaeckebeen elck een aen tast,

Op niemant, groot, noch kleijn, hij past,

Dies raeckte hij in 't werckhuis vast.

This is Verdonck, that bold bloke,

Whose jawbone will give everyone a stroke,

He cares not be ye big or small,

The house of correction was his call. ${ }^{202}$

The etching, the painting, and the historical man depicted, who gave the painting its alternative title, have been convincingly contextualized by $\mathrm{P}$. J. J. van Thiel. He explained that the historical Verdonck was not someone who would actually violently attack others but whose 'jaw' or mouth was a powerful weapon in a fierce conflict, in this case between two Haarlembased parties of Anabaptists. ${ }^{203}$ Van Thiel also noted that the painting alludes to the biblical story of Samson, who killed a thousand Philistines with an ass' jawbone.

In the first instance, there appears to be a witty, intertextual, anachronistic, and Renaissance-like dynamic at play. Yet the fact that this is not an ass' jawbone, but a cow's, as the title also makes clear, suggests a difference that may be pivotal. Or, it makes a difference. It opens up different worlds by means of two counterfactuals related to two separate historical worlds. There is a comical one: what if Samson had had a cow's jawbone instead

202 Jan van de Velde II, 'Verdonck, after Frans Hals', etching and engraving, Philadelphia Museum of Arts. My translation, FWK.

203 P.J.J. van Thiel, 'De betekenis van het portret van Verdonck door Frans Hals'. 
of an ass'? And there is a more serious one: what if Verdonck had really attacked people with this jawbone?

Hals' work can be considered here as preparing the ground, artistically, for what would later become a pivotal philosophical issue. The problem of how to think of this world in relation to equally possible others was key, half a century later, to the paradigmatic baroque philosopher Leibniz, who introduced his ideas of separate enclosed worlds, so-called monads, with La monadologie (The monadology) in 1714. For Leibniz and many of his contemporaries, such as Spinoza, the issue of causation in a God-made world that consisted of different substances was a major philosophical puzzle. Leibniz had to refer back, for this, to the theory of ocassionalism that had troubled itself with the way in which things are caused and how this could involve entities that were created differently, consisting of different substances (body and mind, for instance). Was God a 'prime mover' who had created different substances, by means of which he had set things in motion and after which they continued to change? If so, would they be changing due to secondary efficient causes or simply as a result of the first divine causation? And how could things that were made of different substances, such as bodily matter and mind, have causal relations with one another? In answer to this question, the most radical version of occasionalism held that all cause-effect relations were mere illusions. To them God recreated the universe in each instance anew.

In the modern mind, to which the baroque forms a pivot, all forms of occasionalism, radical or not, would have to be rejected, as they were by Spinoza and Leibniz, though with a twist. Leibniz agreed with the fact that there are worlds that cannot affect one another causally when they are created from different substances. It is only within one world that effective causes may be seen to work. This led him to assert that there are different, radically separate worlds, which he called monads, that are not able to relate to one another in terms of cause and effect. According to Leibniz, the monadic world we were living in was the one chosen by God, because it was the best one: that is, the most intense one. For Spinoza, the existence of other real worlds was, in one sense, of little value. Radically materialist as Spinoza was, he rejected the actual coexistence of possible and real worlds. But this was not because he thought that our world was the only possible, let alone predestined one. His question was how this world was necessitated, on the basis of the principle of sufficient reason, a theme he worked out in Ethics. There he stated, for instance, that: 'if a certain number of individuals exists, there must be a cause why those individuals, and why 
neither more nor fewer, exist'. ${ }^{204}$ So, if this world could be considered as one among a myriad of possibilities, the central questions had become what necessitated this world, why it did not become another world, and even how the non-existence of a world could be explained.

At stake, in the end, was the very nature of history and world, and whether this was man-made, mechanically or artificially made, or divinely predestined: or, more principally, whether history was free in the sense that it could develop itself in any kind of direction. Instead of steadily moving toward a predestined goal, history could be ruled by ruptures then, could be whirling instead of progressing in a linear line, could even be considered fragmented, as Walter Benjamin or Eugenio d'Ors would have it. It is this turbulence of worlds in history that is distinctly baroque. When Greg Lambert deals with the current 'return of the baroque', he notes that such a return is 'inscribed within a negation of historical causality', with which he does not deny causality per se but the so-called necessity of historical continuity. ${ }^{205}$ With respect to this issue, I consider the Dutch republican baroque sublime in the sense that it brings us to either the split-second and overwhelming moment of simultaneous realities or to the consequent unbridgeable gap between them. The world's infinity, in this respect, consists in its being made, practically, in its being actualized out of coexisting, possibly real or really possible other worlds. ${ }^{206}$

Regarding history, the tragic sublime overwhelms by confronting an audience with a world's solitude as the unfortunate outcome of unpredictable, seemingly fated actions. In contrast, the comedic sublime overwhelms because of the human subject's capability to actualize a separate world, in which death is not paramount but in which prosperity, happiness, or luck, dominate. As said, this cannot be a matter of simply making such a world. Anybody at the age of twenty in 1590 and fortunate enough to become sixty in 1630 would have witnessed a radically different Amsterdam. Someone who was twenty in 1615 and lived to see the new city hall in 1655 would have lived in yet another set of Amsterdams. Many things had been made in and by republican Amsterdam. Yet, the role Amsterdam found itself playing and the global scene it found itself in, were dramatically actualized, moment after moment, in a world that was constantly split off from the previously known one, or from another unfortunate one. Frans Hals, more than anybody else, managed to capture this dynamic from the happy side.

204 Spinoza, Ethics: Part I, p. 46.

205 Gregg Lambert, The Return of the Baroque in Modern Culture, p. 42; cf. note 29.

206 I am referring to Gilles Deleuze, Spinoza: Practical Philosophy. 
He embraced this new, baroque world, finding infinity in the fold. If his work overwhelms it is not because of a divine presence that towers over this world. Hals' work overwhelms with expressive, painterly captured, worldly joy. It is paradigmatic of the Dutch Republic's baroque nature, which consisted in the exuberant, at times highly confusing, and for many threatening whirlpool of colliding worldviews in the public domain, but also in the equally confusing but also liberating idea that one world embodied the potential of many.

For those who might now think that a republican baroque would imply radical freedom, let me move to a sobering issue. When Hugo Grotius came up with his republican idea of the free seas this implied that the seas had been framed from now onwards, that is to say: defined as free in a politicoeconomical sense but framed legally. 
This content downloaded from 132.229.156.144 on Tue, 05 Feb 2019 10:42:57 UTC All use subject to https://about.jstor.org/terms 


\section{The seas or the world as scene - Focquenbroch and Grotius}

\subsection{Pre-colonial mise-en-abyme: Focquenbroch and a non- republican baroque}

Acting as a sailor on a voc or WIC ship, a ship sailing under the flag of the Verenigde Oostindische Compagnie (United East Indian Company) or Westindische Compagnie (West Indian Company) was commonly considered to be shameful, as a result of which many sailors were recruited, or bought, elsewhere ${ }^{207}$ Karel Bostoen, in his short study on the figure of poet, playwright, and medic Willem Godschalck van Focquenbroch (1640-1670), states: 'Those who went to Africa on behalf of the wIC belonged, by and large, to the scum (criminals and beggars)'. ${ }^{208}$ This was the company in which said Focquenbroch found himself when, after he had not been able to make enough of a living in Amsterdam, he applied for the job of 'Fiscaal' (a kind of public persecutor) with the WIC. On 17 July 1668 he set out on a ship named The Gideon which was to bring him to the isle of Saô Jorge da Mina, as it had been named by the Portuguese. What was now St. George d'Elmina had rapidly grown into the most important hub for Dutch slave traders and a key foothold along the coast of Ghana. ${ }^{209}$ Expecting easy money, Focquenbroch must have underestimated what he was headed for. As Bostoen notes, the so-called Goldcoast was also known as 'the grave of the white man'; a study into survival rates of English personnel sent to Africa concluded that $60 \%$ died within eight months. ${ }^{210}$

207 On this, see the 'Inleiding' (introduction) to Overbeke's diary and letters by its editors, Marijke Barend-Van Haeften and Arie Jan Gelderblom, in Aernout van Overbeke, Buyten gaets, pp. 9-37, quote from p. 16.

208 Karel Bostoen, 'Opgewekte berichten uit het droevig Morenland', p. 6. In the original: 'Wie voor de WIC naar Afrika ging, behoorde meestal tot het uitschot (veroordeelde boeven en bedelaars).' On the general situation, see J.M. Postma, The Dutch in the Atlantic slave trade, $1600-1815$.

209 The history of the island as a hub of the Dutch-African slave trade has been described recently by Marcel van Engelen, Het kasteel van El Mina.

210 Karel Bostoen, 'Opgewekte berichten uit het droevig Morenland', p. 6. On Focquenbroch also see: E.M. Beekman, The crippled heart. On his at times awkward reception in Dutch literary history, see René van Stipriaan, 'De mythe van de miskenning of de grillige roem van Willem Godschalck van Focquenbroch'. 
After a hazardous journey, Focquenbroch landed on 18 September and described his experience in a letter dated 22 September:

\begin{abstract}
Actually it is simply impossible to tell you about the miraculously strange things (which I had never seen before) that I noticed here, full of wonder and astonishment, when arriving. [...] The castle lying there, from afar, white, beautifully glimmering, as it is being built on a rock that has been hewn on all sides (its foot being flushed and kissed by the big ocean with a sky high surf), and canals on the landside reaching into what seems like an abyss. Me myself, having reached land and having gotten a little closer, I discovered that the entire beach was swarming with thousands of blacks, whose color, nudity, strange movements, shouting and rejoicing, in sounds that were unknown and barbaric for me, made me so miraculously excited that, as if enchanted, and completely outside of my self, I wrestled myself through this spooky/boiling mass, to get into the castle and thus near the Lord General. ${ }^{211}$
\end{abstract}

This passage is an excellent illustration of the almost instant alienation of the Westerner who enters a completely new world, but also of the baroque shock, a colonial one here, that is the result of two radically different worlds and cultures colliding. The word 'miraculous' (wonderbarelijck, wonderbaerlijck) appears twice and, notably, can be translated into Italian as meraviglia - the term paradigmatically used to indicate the effect of baroque art. The first time, it is used to qualify a first impression of the entire environment and situation. The second time, it is used to describe the feelings of the newly arrived Focquenbroch. The combination of the two leaves the doctor feeling 'enchanted' or 'mesmerized' (als betovert). In a sense, he experiences the reality in which he finds himself as a dream that leads to a doubling of perspective. 'Completely outside of my self' (gansch buyten mijn self), Focquenbroch is someone who is looking at himself from a sort of distance, and at the same

211 Willem G. van Focquenbroch, Afrikaense Thalia. In the original: 'U nu de wonderbarelijcke Vreemdigheden te verhalen, die ick hier op mijn aenkomst (als voor my noyt gesien) met verwonderingh, en verbaestheyd aenmerckte, souw my 't eenemael onmogelijck zijn; ... Het Casteel van verre, Wit, en heerlijk afschijnende, en gebouwt op een Rondom-uytgehouwe Rots (wiens voet van de grooten Oceaen met een Hemels-hooge Barningh bespoelt, en gekust word) en wiens Graften aen de Land-kant tot in den Afgrond schijnen te strekken: van my aen Land komende genadert zijnde, bevondick te grimmelen, gelijck als mede de gansche strand van Duysenden van Swarten; Welckers verf, Naecktheyd, vreemde Posturen, Geschreeuw, en Gejuygh met ongehoorde, en Barbarische Toonen, my so wonderbaerlijck op getogen maeckte dat ick als betovert, en gansch buyten mijn self, door dien Spoockenden hoop door-dringende, endelijck tot binnen in 't Casteel, en soo voorts by den Heer Generael geraeckte.' p. 160 . 
time he is a body wrestling itself through a whirling collective of other bodies. The adjective spoockenden condenses telling connotations. A spoock is a ghost but the verb spoocken can also be used in Dutch to indicate extremely bad weather. As a result, the mass of bodies that surrounds Focquenbroch is metaphorically compared to a boiling sea.

Focquenbroch would not last long at his post in the castle of St. George d'Elmina, where he had hoped to be paid for his efforts in gold. He died after two years in 1670 , aged thirty, probably the victim of one of the many epidemics. As said, this was not uncommon. In the meantime, he had been sending letters to the home front. The ways in which these letters attest to seventeenth-century attitudes towards slavery, slave trade, and blacks (female or male) has been adequately sketched in the aforementioned study by Bostoen. Despite the many prejudices at play, these letters were penned long before the activity of trading slaves became part and parcel of a racist, ideologically underpinned, and expanded system. The anxieties involved on Focquenbroch's part had, as yet, not been neutralized by a racist ideology. Yet things are definitely, physically and psychologically, out of joint.

This force field is captured, baroquely, in a painting by Pieter de Wit from 1669. It was probably ordered by the one whom it depicts: Dirck Wilre, director-general of the West Indian Company in the castle of St. George d'Elmina. It is this very 'lord-general' to whom Focquenbroch flees in the previously quoted passage (see figure 17). The way in which Bostoen describes the scene is telling: 'At the margin of the painting, at the background left and functioning as an aside in a theater play, a skinny, slightly moody looking man bends forward on a balustrade. ${ }^{212}$ Although it is cut off by the painting's frame, text runs beneath the balustrade, saying: 'God's blessing r... ${ }^{\prime 213}$ Bostoen suggests that this figure is Focquenbroch: a suggestion based on the Bulletin van het Rijksmuseum from 1979, and which has been widely taken up as fact, although Focquenbroch at the time was bald, and this man has long, smooth, and slightly greasy hair. Then again, as Bostoen notes, it could be a wig. ${ }^{214}$ More important in the context of my argument

212 Bostoen considers the position of Focquenbroch from his position within the painting by describing him on the left. Bostoen, 'Opgewekte berichten uit het droevig Morenland', p. 2. In the original: 'Aan de rand van het schilderij, links op de achtergrond en fungerend als een soort terzijde in een toneelstuk, leunt voorovergebogen op een balustrade een magere, wat somber blikkende man.' For his source, see Franz Binder and Nornert Scheeloch, 'Dirck Dircksz Wilre and Willem Godschalk van Focquenbrogh'.

213 The painting says: 'Gods zeegen b...', perhaps 'blijve', so this is why I put the ' $r$ ' of 'God's blessing remain...' in my translation.

214 Bostoen, 'Opgewekte berichten uit het droevig Morenland', p. 2. 
is Bostoen's comparison of Focquenbroch's position with a theatrical one. Focquenbroch is either functioning as an actor on the margins of a stage, 'on the side', or he is an actor who addresses the audience directly in an aside. As such, the figure in the margin may attract more attention than the figures in the center. The latter are to be looked at, theatrically, while the former addresses us dramatically.

The painting's bottom can be defined as 'a double freeze'. The movement of the dog suggests it may be an extended sort of stair. Either as freeze or stair, the result is that we are looking at something being staged on a stage. ${ }^{215}$ Yet, in terms of staging, the painting shows as much as it does not show. In the Dutch Republican context Wilre could also have been depicted with his wife Helena Correa, daughter to an African woman and the last Portuguese governor of Axim. Helena Correa had been married to the previous Dutch director-general as well, and had married Wilre in $1660 .{ }^{216}$ The couple had three children together, with one son surviving. Correa was likely the reason Wilre wanted to stay in Elmina, although in 1666 he was in the Republic for a short while and married a Dutch wife: Maria de Perel. ${ }^{217}$ The letter on the table is addressed to her.

The African man with the feather headwear is a remarkable figure in his own right. ${ }^{218} \mathrm{He}$ is clearly not a slave, considering his attire. He is either a ruler or a trader and turns the scene into a contractual one. Yet, it is a contractual agreement in which the African man is presenting the very island by means of metonymy. He is offering a painting of the island itself, St. George d'Elmina. As such, he adds quite another theatrical level. He is not just showing a painting, but a painting from which he is pulling the curtain aside as if opening up the stage that will be taken by the Europeans. Since that stage is the very Elmina depicted, this is a mise-en-abyme: the African man is both in charge of the painting and projected into the depth of its image.

215 The information is derived from the site of the RKD Netherlands Institute of Art History, https://rkd.nl/nl/explore/images/16652

216 On the ways in which the Dutch, Portuguese, and African kingdoms allied with one another and fought one another in relation to the developing slave trade, see Mark Meuwese, Brothers in Arms, Partners in Trade.

217 Franz Binder and Nornert Scheeloch, 'Dirck Dircksz Wilre and Willem Godschalk van Focquenbrogh (?)', p. 49.

218 For representations of Africans in Early Modern art, see T.F. Earle and K.J.P. Lowe (eds), Black Africans in Renaissance Europe, and David Bindman and Henry Louis Gates jr., The Image of the Black in Western Art. 
Another dominant feature of the painting is an impressive gilt-leather wall covering; according to the Bulletin van het Rijksmuseum, it is the painting's most striking feature. It might have been made in Amsterdam around 1640 and seems to be the same as a wall covering in a painting by Pieter de Hoogh from 1665 entitled Leisure Time in an Elegant Setting. Yet, even if this wall covering is indeed the same as the one in the Pieter de Hoogh painting, it works radically different here. ${ }^{219}$ The wall covering effectively works as an artificial introjection of the jungle's texture in the space of the room, as a result of which the jungle is no longer beautiful, sublime, or horrific theatrical décor, no longer an 'outside', but an always close and present, dramatic inside. Instead of expressing the wealth and 'leisure' of a Dutch interior, it compresses space into something in which the actors are being implicated. The wall covering is a mise-en-abyme, here, for how the entire painting works through a fluid alternation between theatricality and dramatization, with the actors of importance on a stage that is not framed by but caught in a wall covering that dramatically overwhelms.

Within this dynamic, the (supposed) figure of Focquenbroch has a similar mise-en-abymic function in relation to the painting's 'faulty perspective' or 'uncertain spatial structure. ${ }^{220}$ In my reading, the perspective can be defined better as a colonial 'out of joint-ness' in accordance with a colonial instability of space. In a distinct sense Focquenbroch is the opposite of what Victor Stoichita described in The Self-Aware Image as a baroque reflection on and of the self. ${ }^{221}$ This is a result of two things. First, the mise-en-abyme has an affective element of depth and scale that has an oscillating quality to it. Second, it does not concern a oppositional reflection with a here-andthere, as when a mirror reflects an image outside of the self; rather, the mise-en-abyme embodies a reproductive reflection that remains internal in the sense that neither the framing nor the framed figure can see the other. The reflection is part of its own image, so the figure is not just reflected or doubled, but is projected to another scale while remaining part of the very same image. This is where the possible confusion between real and mirrored becomes vertiginous. When the supposed Focquenbroch is seemingly addressing the viewer directly, and dramatically, his position is also one of a mise-en-abyme in that he is at a distance and not looking outside of the

219 Ibid. De Hoogh's painting can now be found in the Metropolitan Museum of Art, New York. 220 The Bulletin van het Rijksmuseum 27 , no. 1, describes the painting in terms of a 'faulty perspective and uncertain spatial structure' which suggests that the painter 'was youthful and inexperienced'.

221 Victor Stoichita, The Self-Aware Image, see also Christophe Eecke, Pandaemonium. 
painting, as with a theatrical aside, but looking outside-in. He is looking at the colonial situation in which he finds himself captured, or looking into the very scene of which he is part.

In the figure of Focquenbroch, the mise-en-abyme captures a colonial world that finds itself at a theatrical and alienating distance from a familiar inside world. At the same time, it captures a convoluted and unfamiliar outside world that is projected inward, compressing different scales of time. The man at the balustrade is looking at his viewers 'now', thus breaking the theatrical 'inside', but at the same time he is looking inside the scene, inescapably part of it, while remaining an outsider in terms of time. The result is unheimlich.

Before his entanglement in the Dutch colonial enterprise, Focquenbroch had made his fame as a poet of the burlesque. Yet, any attempt to use the burlesque or grotesque to rearrange the stage did not work here. He remained caught in a mise-en-abyme, not able to stage himself or to act, but dramatically lost. His position and feelings are nothing close to what slaves had to go through, either when kept in the spaces beneath the castle or when transported to the Americas. A baroque colonial sensibility differs principally from a republican one, here, and it can be characterized by this element of out-of-jointness, or dislocation, which makes the republican baroque topple over into something radically different. The depiction of the colonialist Dutch characters and the black man no longer hints at an open collision of worlds of which one will become actualized. Instead, the lifeworld of the one is appropriated by the other in a system of terror.

The issue of appropriation was key in this context and due to the Republic's quasi-imperial expansion, the issue troubled it from the beginning.

\subsection{Moment of exchange and the non-existent 'proper'}

In the colonial endeavor that the Dutch Republic embarked upon, it did not just find itself in a different position, it helped produce a new world scene, in which it found itself at the same time. Initially, trade was paramount. Soon, however, one of the more vexing questions became when one could take something as one's own, whether this be land, resources, products or goods. Moreover, trade was often intrinsically related to forms of warfare, bound up with conflicts between the Republic and the Spanish, the English, and many others. In this context one prominent and disturbing act of thievery was the capture of a Portuguese carrack, a ship of about 1.500 tons, by the 
Dutch captain Jacob van Heemskerck in the Strait of Singapore in $1603 \cdot{ }^{222}$ Van Heemskerck was sailing in the service of the Dutch voc at a time that the Dutch States were at war with Spain, which in turn ruled Portugal. Van Heemskerck did not know beforehand that the worth of the Santa Catarina and its cargo, when auctioned off in Amsterdam one and a half years later, would amount to a staggering three million Dutch guilders. Though the lucrativeness of Portugal's trade with Asia had not been widely known up until this point, now it was out in the open. However, there was the thorny problem that Van Heemskerck had carried no papers proving he had a privateer's commission from the Dutch authorities. In fact, he had been in charge of a peaceful trade mission, and his superiors had ordered him not to use force, except in self-defense. Still, Van Heemskerck's bold prize, or 'spoils', of 300,000 pounds sterling, half the sum of the voc's subscription capital at the time, was enough to give the authorities pause. ${ }^{223}$ It was a sum worth the effort to claim as one's own. But, was this a proper claim?

Enter Hugo Grotius, just 21 years old, and trained in law and in the liberal arts. He was asked to write a short apology in answer to the Portuguese/ Spanish accusations that were to be expected. The short apology grew into a vast piece of work, a manuscript, that was completed in 1609 under the working title 'On the Indies'. The case had brought Grotius to explore the ins and outs of the universal law of war, with a great interest in both commerce and the ways in which different states and cultures relate to one another. His study would appear centuries later under the title Commentary on the Law of Prize and Booty, but the initial manuscript itself shows how major themes of Grotius' later work are already explored here as a way to theatricalize a world that had been dramatically changed.

In order to deal with the 'capturing' of the Santa Catarina, Grotius had to go back to the original meaning of proprius, which led him to state that originally, 'under the primary law of nations', that is to say natural law, 'there was no private property'. ${ }^{224}$ Different meanings of proprius collided here, namely that which was one's own in particular, and that which was naturally one's own. In fact, Grotius states that the natural situation is one in which nobody can have anything of their own, particularly. In a sense this was alien to the seventeenth-century mind, but not altogether. The alienation

222 On the matter, see M.J. van Ittersum, 'Hugo Grotius in Context'. A broader picture is sketched in Van Ittersum, Profit and Principle.

223 James C. Boyajian, Portuguese Trade in Asia Under the Habsburgs, 1580-1640, pp. 150-151. This amount comes to an estimated 46 million euros of current purchasing power.

224 Hugo Grotius, Commentary on the Law of Prize and Booty, p. 316. 
provoked by this natural origin recalls the constitution of property, as it was proclaimed in the Early Modern period to be a natural thing. But was it? Or was that so-called naturalness an ideological consequence of a principal theatricalization of things as property? It is this question, involving either the naturalness of the world or its principal theatrical and juridical alienation, which underpins the kind of theatricality I will be discussing in this chapter.

The particular moment at stake - Van Heemskerck's taking of the Portuguese carrack - can basically be considered as a moment of exchange: the moment at which, and then after which, one can call something one's own, or consider it to be in one's possession. Stealing is, in this respect, only the most radical manifestation of an exchange, and the potentiality of theft is something that always remains palpable in every ordinary act of exchange. ${ }^{225}$ Every regular, commercial act of exchange will be somehow precarious because of the possibility of theft that is intrinsic to the moment of exchange. The precariousness of this moment of converting property can be sensed best in the more charged kinds of commercial transactions, those that are not automatic or ordinary: when, for instance, one buys a house, and the transfer of property and money can never be exactly simultaneous. It is precarious because of the real time in which it takes place, as a result of which there is the threat of an imminent outcome that is different from the one expected.

As a result, exchange is clearly dramatic in the sense I have come to understand the term in this study. Someone has to act first: to give either the money first, or the goods. This actor is followed or watched by someone who is temporarily an audience but also an actor nevertheless. Then things change. Those formerly in the position of audience become actors, having to act in response and give something in return. As my choice of words indicates, I consider the in-between moment of exchange to be indeed a moment of acting, a dramatic moment.

In what follows, I will first consider how the capture of the Santa Catarina was dealt with juridically, how this dramatic moment came to be considered as a matter of precedent. In that context it had to be framed. As we shall see, this framing was effectuated theatrically, by means of a staging. Dramatic moment and theatrical framing taken together related to a historically new scene. Paradoxically, whereas Grotius was very much concerned with

225 After an experiment in getting people to exchange rather than steal, Erik O. Kimbrough, Vernon L. Smith and Bart J. Wilson concluded that exchange is a form of convention, just as Hume would have it. See 'Exchange, theft, and the social formation of property.' If, indeed, exchange is a convention, then this would support my argument that people will always sense what would have been, or will be, the case without such convention. 
the proper and property in this case, his juridical attempt to defend what had happened required him to reconsider the very nature of the seas, which could no longer be natural. Grotius came to consider ships out on the sea as actors on an artificial stage, acting in no man's territory but at the same time in a space that was juridically framed as a Mare liberum, the so-called 'free seas'. ${ }^{226}$ As a stage, involving seafarers interacting with one another as both actors and audiences, this was different from what I will explain as commercial podiums or platforms. Taken together, commercial platforms and the seas as a stage implied a radically different world scene for seventeenth-century human beings, one that also implied a new phase in history: colonialism.

\subsection{Juridical staging: commerce and the seas}

To Grotius, the judicial issue was not so much how someone owns or possesses something, but rather the illusive moment at which something changes hands. This involves a stage in several senses of the word. Firstly, the stage is determined in terms of time, as when one says 'at that stage'. Here, 'stage' indicates the previous and later states of a situation and consequently a movement, the state of movement, and the movement of a state. Secondly, the stage is determined in terms of space. An exchange always takes place in a defined space. This double meaning connotes the illusiveness of this moment of transformation. As such it provoked the lengthiness of Grotius' study. He was asked by a befriended connection in the voc to write a short apology and then apparently felt forced to come up with a thick manuscript in order to provide himself and his readers with a counterweight for something that, in the end, cannot be grasped, cannot be represented in itself, but nonetheless needed to be staged for judicial purposes.

The illusiveness at stake is perhaps apparent when Grotius introduces the topic of his book. He sketches the broad frame first, but he also has to make clear from the beginning what particular event incited his writing. This is how he describes it:

In the year 1602, after several manifestations of hostility on both sides, it so happened that Jacob Heemskerck (Commander of the Amsterdam fleet of eight ships lying in the Strait of Singapore [...]) forced a Portuguese 
vessel to surrender and, disbanding its crew, sailed it home. This vessel, the Catharine by name, a ship of the class known as 'carracks', was laden with merchandise. ${ }^{227}$

Notice that there is not a word of capturing, seizing, apprehending, or taking . The entire issue of ownership or possession is skipped or veiled by defining what happened as an 'act of surrender', which suggests that the opposing party acted of its own will. Secondly, there is the subtle distinction between the ship and its cargo, understood as merchandise. Obviously, the rhetorical strategy of Grotius is to avoid judicial mistakes. Every word can be too much.

Still, there is a more fundamental issue at stake. The question is at what moment and on what grounds Van Heemskerck came to 'possess' the Catharine after it had 'surrendered'. Or, to put this more precisely, when Van Heemskerck had defeated the ship he could claim to possess it; when he and his men entered the ship they could claim to occupy it. But how, when, or through what kind of transition could they claim to own it with its contents? This is the riddle that haunts Grotius, and he will need the dynamic between the dramatic and theatricality to solve it.

Conducting an internal economy that operated through supply chains, the Northern Low Countries, or the Dutch Republic, operated rather differently externally. ${ }^{228}$ Sending out ships all over the globe, the Dutch Republic did not mean to supply its centers of power elsewhere, or if so, only in relatively small numbers, to a minor degree. The centers elsewhere had to be able to exist on their own as much as possible, aside from the import of weapons. So ships went out partly to supply, but predominantly to trade. Because of the many wars that were fought in Europe at the time, there was also this other possibility: to take possession of something that belonged to the enemy. This mostly entailed stealing other ships and their cargo - as in the case of the Santa Catharina-and this 'stealing' could either be a simple act of warfare - in which case it was not stealing but a form of conquering, piracy — or a licensed form of weakening the enemy by taking things from him.

The precariousness of exchange in relation to the propriety of behavior and possession was not a specifically Dutch concern, nor a strictly religious, moral, ethical or juridical issue. The internal web of Dutch cities

227 Grotius, Commentary on the Law of Prize and Booty, p. 14. The difference between 1602 in Grotius' text and my 1603 concerns a reconfiguration because of different timetables.

228 For a short analysis of the Dutch economic system in the seventeenth century in international contexts, see Liah Greenfeld, The Spirit of Capitalism. 
was connected to a European network with nodal cities in the northeast, England, France, Portugal, and eventually the Ottoman Empire; in turn, this European network linked with trading partners all over the world. The most important of these were not just trade partners but also military allies at times, in the Dutch case mostly against the forces of the vast Spanish Empire. Still, it was relatively easy to switch sides, and this was done with the full awareness that one might later have to switch sides once again. Politically speaking, there was every reason to be cynical about this flexibility. Yet, the flexibility of alliances also indicated that players knew they would need to balance one another in the long run, if only to make sure that an often recently developed and in all cases precarious sovereignty could be preserved. This, for instance, was a major motivation behind the Westphalian peace treaty of 1648 and the later peace treaty of Utrecht in $1713 .{ }^{229}$

This awareness of precarity was particularly acute in matters of trade and finance, where a certain stability and trust had to be the rule. When Benedict de Spinoza, in his Tracatus theologicus, described Amsterdam as a city full of diverse and even disparate people, he also mentioned that the one thing that kept it together was trustworthiness and liability in commercial matters. Both in matters of trade and of alliance, then, one could not do anything. Economically, propriety was an issue in relation to finance, trade, and contracts; politically, it was an issue in relation to long-term relationships and one's own sovereignty; legally, it was an issue in relation to national and international laws concerning the acknowledgment of property, newly gained or claimed, respected as one's own or another's. ${ }^{230}$ In the latter context, players such as the United East Indian Company, the voc, were a considerable complication. On the one hand, they were private parties, with quasi-sovereign forms of responsibility. On the other hand, they clearly functioned within the frames of the sovereign states that made up the Dutch Republic, or within the frame of the Republic as a whole, embodied in the States-General.

The title of Chapter XII in Grotius' work, 'Justness of the Case if the War Were Private', indicates that a mixture of state-organized and private economic interests and commerce is indeed at stake. The theses Grotius puts forward in this chapter emphasize this. Thesis 1 , for instance, has it that 'Access to all nations is open to all'. Thesis 2 states that 'Infidels cannot be divested of public or private rights of ownership', and Thesis 3 that 'Neither 
the sea itself nor the right of navigation thereon can become the exclusive possession of a particular party, whether through seizure, through a papal grant, or through prescription (that is to say, custom). ${ }^{231}$ It is on this last thesis that I shall focus.

The first question is what the sea is in terms of property: whether it is res nullius, common property, or public property. This question forces Grotius to go back to the original meaning of proprius: private. As I have already mentioned, originally, 'under the primary law of nations', or natural law, so Grotius mentions, 'there was no private property'. ${ }^{232}$ The fact that people made use of land could not be considered a form of proprietas: possession. This all started to change because of consumption: 'Some things are consumed by use. ${ }^{233}$ Having used a tree to make a house I cannot say I possess that tree, but I somehow came to own it in using it. The use of movable things as a form of ownership then shifted to immovable things, such as land. Here natural law had to give way to positive law. Man-made laws had to regulate how user or consumer and object were 'attached' to one another; within that context the physical act of attachment is described as occupatio. Grotius gives a quote here by Seneca. It is a quote, tellingly enough, about theater.

A certain place in the theater, so Seneca argues, may belong to all Roman Knights, 'yet the place that I have occupied in those rows becomes my own. ${ }^{234}$ Such occupation is a distinct embodiment of the mutual implication of audience and performance. Just as a seat will be mine for the duration of the performance, the stage will also be occupied by the performers and will be theirs. There are also different personas, different actors in play. Seneca can only claim to occupy his seat as a Roman knight, as a legal person. Likewise, the performers can only take the floor as certain characters.

The form of tenure of immovable things is different from that of movable ones. Here 'occupancy implies physical seizure [apprehension].' A quote from Vergil's Georgics that stages how men may seize animals by 'trickery' and 'snares' indicates that we are now outside of natural law and in the realm of artistry. ${ }^{235}$ Equally artificial is the distinction put forward by Ovid that the construction of houses led to the seizure of soil, which 'hitherto had been a common good like sun and air. ${ }^{236}$ That is to say, Ovid, in this

231 Grotius, Commentary, p. 300.

232 Grotius, Commentary, p. 316.

233 Grotius, Commentary, p. 317.

234 Grotius, Commentary, p. 318.

235 Grotius, Commentary, p. 319.

236 Grotius, Commentary, p. 319. 
quotation, refers back to the strange transition through which soil could suddenly be occupied, owned, or better yet, possessed. In terms of possession Grotius has to make a leap here. Without any explicit transition he states that the subsequent stage is commerce, as a quotation from Ovid highlights: 'The keels of the ships leapt over unknown waves. ${ }^{237}$

Grotius' connection between commerce and sea is not coincidental. The theme that occupies Grotius is 'attachment', or rather, forms of attachment. Working his way towards the contention that nobody can be attached to the sea in terms of ownership, seizure, or possession, Grotius introduces a relation between commerce and sea that is motivated indexically, iconically, and symbolically, which is to say by language and by law. Sea and commerce implicate one another intrinsically not because the sea is an article of commerce, but because the sea 'carries' commerce:

In short, the sea is included among those things which are not articles of commerce, that is to say, the things that cannot become part of anyone's private domain. Hence it follows [...] that no part of the sea may be regarded as pertaining to the domain of any given nation. ${ }^{2{ }^{8}}$

Not belonging to anyone's domain, the sea can become the platform on which and through which commerce can take place. This becomes clear a little later when Grotius states that:

neither discovery nor occupation can have any bearing upon the freedom of trade. For the right to trade freely is not a corporeal object, susceptible of seizure. ${ }^{239}$

Now, Grotius knew full well that one can buy, and therefore trade, rights. The point is that one cannot buy or seize commerce itself. The link with theatricality is a double one here, and it concerns the issue of materiality. Whereas the sea can become a stage, and whereas ships can become actors, commerce is something dramatic that is not seizable, graspable. Consequently, in dramatic terms the sea is a podium, a floor that can be 'taken', but never owned, by actors. In this context, commerce itself is much more elusive. It can only be perceived as something that is being staged by actors, by their dramatic interactions, which result in a change in 
self-awareness. This is to say that the illusive status of commerce coincides with the momentary installation of a platform or a podium on which and through which something is acted out, like, say, an exchange. Such a podium is not stable. It can be taken, in the dramatic sense of 'taking the floor'.

Juridically speaking, however, something is also being staged in what becomes a mise-en-scène, as when ships become personas through their flag. This mise-en-scène takes place on a sea which Grotius claims should be framed as 'free' in the sense that it can be no one's property. Paradoxically, as such a juridical space, the sea has become a stage, defined in terms of property, as anti-property. To this order, Grotius follows Thucydides and in doing so qualifies the space concerned as aopistov (aoriston), that is to say: something that is 'undefined', marked by 'no fixed limits'. ${ }^{240}$ These are not spatial limits that could indicate some sort of dominion. Rather, the region concerned is undefined in the sense that it cannot truly be occupied or possessed. When Grotius argues against the act of navigation as an act of occupation he states that 'no one is ignorant of the fact that a ship sailing over the sea no more leaves behind itself a legal right than it leaves a permanent track'. ${ }^{241}$

In relation to this, the difference between actors and characters is relevant. Actors and performers can 'take the floor' in the sense that they occupy it, as one occupies a seat. Characters, however, cannot be defined in terms of what they occupy, or in the sense that they take the floor. They appear through the fact that something is being staged. Likewise, ships take the floor, in order to allow commerce to happen. But what exactly is happening, or what has happened, is decided by defining the scene in, on, or at which they appear. This scene can be defined juridically or ontologically, as a world scene. Let me deal with the juridical and theatrical definition first.

\subsection{The precariousness of mise-en-scène}

No form of art is as vulnerable as theater, not even performance, music, or dance-which are also created in real time. The precariousness involved consists in the continuing, dramatic balancing act that interacts with the primary moment of theatricality, the installation of a stage. Captured within its frame, the scene appears to be stable, but in relation to the dramatic actions that evolve, both actors and audience are somehow being given over

240 Grotius, Commentary, p. 320.

241 Grotius, Commentary, p. 334. 
to' the dramatic situation and as a result become highly sensitive to their surroundings, the things taking place and the way in which participants reflect on these and these reflect back on them.

With theater there is the continuous choice, at the beginning and throughout the performance, to be and to remain involved both dramatically and theatrically. Still, there is also an element of subjection, not in the sense of a suspension of disbelief but in the sense of this 'being given over to' the theatricality of the situation. This theatricality produces a form of alienation that heightens one's self-awareness, though one is not in control of this state. This does not deny a critical element, as is apparent in a definition of the theatrical by theater scholar Maaike Bleeker as 'critical vision machine'. ${ }^{242}$ It does deny a fully conscious and analytically restricted form of criticality. The criticality involved concerns the awareness of being enveloped in a situation that is being staged and runs through different stages. Such awareness is especially intensified because of the precariousness of the real-time state of theatricality, as one that imposes itself but can simultaneously be broken and lifted at any moment, that is: dramatically.

The text of Grotius' Commentary is, obviously, not a theatrical or dramatic real time object. As a text it can be put aside, interrupted, or leafed through. Still, it should not be seen as a narrative or argumentative whole that is ruled by a plot or the evolvement of the argument, but rather as the development of consecutive stages, or as something being staged. The first hint of this is given at the very beginning when Grotius describes his text as taking part in such a complex, and apparently ongoing, debate that 'all the various forms of discourse customarily employed by orators' are required. ${ }^{243}$ Starting with a prolegomena, he speaks, and asks the reader 'to be patient and to accept on faith for the moment my assurance as to what the event will later confirm'. ${ }^{244}$ This is the moment of choice, at which we are asked to be patient and wait for the following 'event'. Basing himself on the classical author Dio, he then mentions how nothing that is written can be valid between enemies. Needless to say, this could invalidate Grotius' entire project. What is needed, therefore, is a common frame, defined here by 'custom', or natural law, and then a stage on which the actors can meet and discuss matters as characters. Grotius' text tries to establish such an architectural, theatrical stage. 
In its final chapter the theatrical quality of Grotius' text becomes explicit, when he talks about those who 'transfer a right'. Whether they sell that right or give it away expecting nothing but gratitude,

they still may not deny that they first considered as their own that which they are now converting into the property of another. For no one can give away what he does not possess. Therefore, both before the court of conscience and in the judgement of civil courts, the individuals who have adopted this course of action find themselves in the same position as those who have accepted ownership [of the prize]. For even the latter receive, not the actual goods involved, but the price thereof; and this moreover, they exchange daily for other things. ${ }^{245}$

Apparently, the entire text has been a form of theater in which the different actors have been brought before a court of conscience or a fictive civil court. In this court, histories are being lived and relived like the history of the seizure of the ship. The reader is brought into the position of an audience, then, implicated by and caught in something being staged, juridically. This something being staged concerns an elusive moment, which is different from an illusion.

In the quotation given above, the elusiveness of the moment of transition of property is made apparent. As for the moment, it is indicated in the first sentence. There is the past of ownership and then the 'now' of 'converting' one's property into 'property of another'. With respect to this dramatic moment of 'converting' or exchange, it may come as no surprise that when, after eleven chapters, Grotius has come to the case itself, the title avoids the issue of seizure. Chapter XII is titled: 'The Prize Would Be Justly Acquired by the Dutch East Indian Company' and Chapter XIII ‘The Prize in Question Was Justly Acquired,' which is a pleasant way of putting it: 'acquired'. Only in the last two chapters is the element of seizure mentioned. Chapters XIV and XV state, consecutively: 'The Seizure of the Prize was Honourable' and 'The Seizure of the Prize was Beneficial'. This brings us back to commerce, but with hindsight; that is to say, it brings us to its effects of commerce. What is skipped, meanwhile, is the moment of transition itself. The fact that this moment cannot be grasped is evident here, first, in the phrase 'those who have accepted ownership', which is surely a strange way of putting it when a ship has been seized; second, in the phrase where they did 'receive, not the actual goods involved, but the price thereof'; and third, in the assertion that even this prize is not truly in the possession of the occupiers, for they

245 Emphasis mine; Grotius, Commentary p. 495. 
will exchange the money again for other things. It is as if nothing is theirs. And in terms of theatricality, indeed, nothing is.

The entire mise-en-scène of Grotius' text is not aimed, then, at decisively solving the question of whether it was proper to dramatically seize the ship. Working in a precarious balance, it is on the level of the theatrical miseen-scène that Grotius tries to substantiate his point. I mean 'substantiate' literally here. The mise-en-scène of Grotius' argument, nicely arranged along the lines of a realistic perspective, produces an audience-subject that can experience things as properly arranged, as a result of which propriety may be metonymically shifted to the case. ${ }^{246}$

Indeed, one major disturbance that theatricality provokes can be indicated by the simple question 'Who owns the stage?' This question has to cover up an awkward moment: that of seizure, or of occupation. And I do not primarily mean a concrete toneel or stage here, but the vanishing mediator that makes a play possible: the mise-en-scène. ${ }^{247}$ Mieke Bal in her use of the term 'mise-en-scène' took seriously the entanglement of the active and passive voice in the term 'mise', and defined it as 'the complete merging of subject into object, and of object—props, things—into subjects acting and acting subjects'. ${ }^{248}$ The 'props' in Grotius' text are like theatrical props in that through his juridical mise-en-scène they have become property or, rather, they have come to appear as property. Grotius was called in to solve something. Something had already happened that demanded him to come up with this juridical mise-en-scène and, in doing so, Grotius, the voc, and Amsterdam were partly producing a new theatrical stage. At the same time, they were making and finding themselves in a new world scene that on a global level implied a 'merging of subject into object, and of object-props, thing -into subjects acting and acting subjects.'

\subsection{Amsterdam: city and sea as world scene}

The intricate network of rivers and canals in the Low Countries proved to be excellent ground for an Early Modern supply-chain economy. Although the water system's proper function was largely to get the water out of land that

246 On this audience-subject and the dual focal point of perspective, see Hanneke Grootenboer, The Rhetoric of Perspective.

247 On the vanishing mediator, see Frederic Jameson, The Ideologies of Theory, and Slavoj Žižek, For They Know Not What They Do.

248 Mieke Bal, Travelling Concepts in the Humanities, p. 112. 
lay (and still lies) below sea level, it also formed a network that connected all the major cities of the Netherlands. As a result, from the late Middle Ages onward, the Northern Low Countries witnessed the growth of a city web that flourished especially in the seventeenth century, with Amsterdam as the hub of world trade. This hub was connected to powerful satellite cities such as Haarlem, Leiden, Utrecht, Rotterdam, and Dordrecht, along with a number of often neglected or less noticed centers of trade in Zeeland and the eastern provinces, such as Franeker, Kampen, Brouwershaven, Zierikzee, and the tiny Veere or Middelburg, where the Middelburg Commercial Company (established in 1720 as Middelburgse Commercie Compagnie) developed into the biggest slave trading company in the Republic within a few decades. Amsterdam could not have become a center of world trade without this web, nor could the incredible wealth of this web have been generated without Amsterdam. As a result, Amsterdam was quite aware of its special status, nationally, but all the more so internationally. In fact, it perceived itself in a special way, related not so much to the stage of the world but to how it had placed itself and had been placed in the scene of the world, or the world as scene.

Above the gateway to the new stone theater (opened in 1638) was written a rather familiar phrasing, Stoic in origin, of the world as a stage. In the version composed by the city's most famous author, Joost van den Vondel, there was, however, a twist to this Stoic phrase. It read: 'The world's a stage for playful art / Each plays his role and gets his part'. ${ }^{249}$ The parallel with Shakespeare - a parallel due to the common Stoic inheritance-is obvious. ${ }^{25^{0}}$ Nevertheless, Vondel's version contains a telling ambiguity. It is not just that everything which occurs in reality is like a play. Roles are distributed and according to this distribution everybody gets 'his part', which can also be read as 'one's fair share'. The phrase, in this respect, may also allude to Amsterdam as the republican, international center of commerce.

Amsterdam was one of the richest and most attractive cities in the world at this time, and as a result it had been expanding for decades. This need to expand dated back to the 158 os when the Dutch, in their struggle with their former king, Philip II of Spain, had managed to effectively block the entrance to Antwerp, by far the biggest harbor of the Low Countries. Partly

249 In the original: 'De Weereld is een Speel-Toneel / Elk speelt zijn rol en krijgt zijn deel.' 250 With Shakespeare, the quotation from As You Like It is: 'All the world's a stage, / And all the men and women merely players; / They have their exits and their entrances; / And one man in his time plays many parts, / His acts being seven ages.' Act II, Scene VII, ll. 139-143. 
because of religious persecution in the Spanish provinces, and partly for financial and economic reasons, the North had seen a huge influx of immigrants, with Amsterdam as the greatest beneficiary. Between 1570 and 1640, Amsterdam's population grew from 30,000 to 140,000 and would keep on growing during the next three decades until it reached 200,000. In our eyes this may not seem a staggering figure. Still, it amounted to a sevenfold growth within two or three generations. In 1585 and in 1593 the need for expansion-also related to the need for a better defense system-had already led to enlargements, the results of which were messy, because former landowners were able to decide what should be built, sold, or rented. From 1609 onward the need for a conclusive and public plan became more and more pressing. The plans for the first big expansion of 1610 were made, in the end, by 'stadstimmerman' Hendrick Staets and geometrician of the city, Lucas Sinck. ${ }^{251}$

The dramatic connotation of their city plan can best be made clear by comparing it with the contemporaneous plan of another large city in the Netherlands. In 1664, Utrecht also had designs on expansion (see figure 18). This is a design derived from both military and civil engineering. The idea came from the mayor of Utrecht at the time, professor Hendrick Moreelse, and was transformed into this plan by fortification expert Hugo Ruys. As one sees, the city remains caught within its walls, looking outward to all sides, whereas it is at the same time a stage to be looked at from above, as the stage of its citizens. The new Amsterdam plan also showed strong influences from military engineering, according to the requirements defined by Vetruvius, which held that the best way to build a good defense was in the shape of a circle. The plan had equally strong links with civil engineering, and the same would hold for the second major expansion plan five decades later. ${ }^{252}$ In Holland new land had been created since the Late Middle Ages by using windmills to turn lakes into arable land, and the resulting new polders were organized mathematically on the basis of rectangular shapes. Yet, what would shape Amsterdam was a mixture of circular and rectangular elements. In the context of the Netherlands, part of the plan's revolutionary aspect was that it did not stick to the blueprint delineated by land and water. In fact, 'the pattern of quays, canals and properties was

251 For all this, see Willem Frijhoff, Marijke Carasso-Kok, Maarten R. Prak, and Nienke Huizinga, eds., Geschiedenis van Amsterdam. A concise description of Amsterdam's expansion can be found in Hans van der Cammen and Len de Klerk, Ruimtelijke ordening, pp. 20-40. 252 Boudewijn Bakker, Amsterdam en de grachtengordel. 
designed entirely apart from the existing landscape'. ${ }^{253}$ The shape that was realized was intrinsically artificial. This became all the more clear when the expansion of 1660 not only built further on the first revolutionary plan, but also created islands on either side of the city entrance, to the west and east, which would come to house the huge shipping wharfs of the voc.

Whereas in Italy the shipping wharfs had helped Galileo establish technological innovations, in Amsterdam, architectural and social innovations would help to establish a new form of subjectivity. Through these innovations, in the Low Countries, and especially in Amsterdam, the waters of the sea would turn into a platform on which to act dramatically. As such, the waters of the sea were distinctly different from the partnership between water and theatricality that was established in various court shows performed in baroque circles of the seventeenth century. In 1635, for instance, the Spanish king Philip IV was part of a spectacle, written and produced by Caldéron de la Barca, entitled El mayor encanto, amor (The most delighted, love). While the members of the court and the king were floating in their gondolas on an artificial lake, with an artificial island in the middle and artificially provoked waves, other players approached and began to perform the history of Circe and Odysseus - a history that ends with the explosion of the island once the latter has escaped. In relation to an audience, this show, or this type of show, worked ambiguously. A general audience could only have learned of it by hearsay. In other words, the stage and play would have come alive as the result of forms of theatrical ekphrasis: a verbal description of what had been shown.

With Amsterdam, however, the situation was different. Let us have a closer look at Daniël Stalpaert's Depiction of the city - with its most recent expansion from 1665 (see figure 19). ${ }^{254}$ At the very front of the painting there is the familiar depiction of the harbor and the city as they would appear on the horizon to arriving ships. The silhouette is surrounded by allegorical figures that define the city as the center of world trade. The image in the background is both more simple and complicated, however. One sees the so-called fourth expansion of Amsterdam, with a considerable portion of the city not yet filled with houses. In fact, the layout of the city was so grand that, after trade slowed down from the 1670 s onward, it would provide the city inhabitants ample space up until the 1850 s. Partly due to this empty space, the city quite closely resembles a classical theater, with some rows filled and others waiting to be filled by an audience. This is emphasized

253 Van der Cammen and de Klerk, Ruimtelijke ordening, p. 28.

254 In the original: Afbeelding der stat Amsterdam: met haar laetste vergrooting. 
in this print by an alienating or dizzying shift in perspective. The layout of the river ' $t Y$, as it is connected to the city, is organized according to rules of linear perspective. Yet, the city behind it folds upward as if it is a map that iconically indicates the rising terraces of the theater. The houses, both indices and icons for the audience, are all directed towards the stage in the front, upon which the actors, in this case the ships, move about. Accordingly, one can read the plan of seventeenth-century Amsterdam as intrinsically theatrical, with the river' $t Y$ as a stage on which the ships are moving.

The shift in perspective from the river to the city behind it, does not simply introduce a formal conflict between two modes of representation, however through it, the city also becomes the stage to look at from the ships. Effectively, the inside-outside dynamic of theatricality is thus replaced by a dynamic that is ultimately internal: citizens of Amsterdam and ships alike are all players on a curved dramatic plane. This implies that the citizens of Amsterdam should be seen here not so much as an audience becoming aware of itself in relation to a perceived stage, but rather as participants in action, involved as dramatic actors on a platform or podium. If one attends to the distinctly different outlook in the Amsterdam print in this way, dramatization comes dominantly into play.

What is missing on the Amsterdam print, and necessarily so, is the horizon of the South Sea, which is much more than a background or a horizon. The artificial islands with their wharves are not missing, although we can easily miss their dramatic quality. Their locations, on the left and the right, turn them into the production houses, spitting out ships-cum-actors onto the platform while also being actors themselves. Any harbor is both synecdoche and metonymy for the wider seas; it is both a small part of the seas, and as a harbor it borders on the seas. Yet here, it has become a platform that works like a mise-en-abyme. It comes to reflect sea as a scene in, on or at which Amsterdam has come to play its role.

Dramatically speaking, something is perceived as being acted out in a space that is not defined beforehand as a scene, but that becomes a scene because of the action. This general condition has a parallel in the origin of theater. In the foreword to his play Adam Exiled, Joost van den Vondel described it as follows: in classical Greece, shepherds would construct a temporary shelter and with that a space of performance: a skènè. In this space, or better yet, by means of it, they would tell each other stories, sing songs, perform. There are two pivotal points here. Firstly, the skènè was not there beforehand: it was made through the actions of people. Secondly, with its establishment, the nature of human selves had been altered: shepherds had become performers. Likewise, and in terms of my larger argument, the 
Dutch republican baroque did not have a scene beforehand, but established one. It formed a historical pivot in that it redefined the way in which a European self had constructed and understood itself in theatrical terms for hundreds of years. This is not to say that the world was simply experienced as 'real' in the Dutch republican baroque. The dream was often a more apt model, though not because dreams are illusions. Rather, once one is in a dream there is no reflective 'outside'. The historical pivot at stake concerns the alternation of a reflective, theatrical, and external stage and the realization of a fascinating and intensifying dramatic plane: a plane of immanence on which the actors involved found themselves in new roles.

The combination of stage and plane that defines the human self as produced through its action-in-appearance, I will call, following Pierre Legendre, scene. The idea of scene implies that people do not coincide with themselves, as Alain Badiou argued in Rhapsody for the Theater. ${ }^{255}$ They find themselves on a scene and, simultaneously, they find their selves through the scene. They have been thrown into it by means of a mise-en-scène. As for this 'being thrown in', it is critical not to read the seventeenth-century situation in the light of the ideologies nineteenth century. The difference between the two cannot be clearer than in the domain of the sciences, to which I move in the next chapter. 


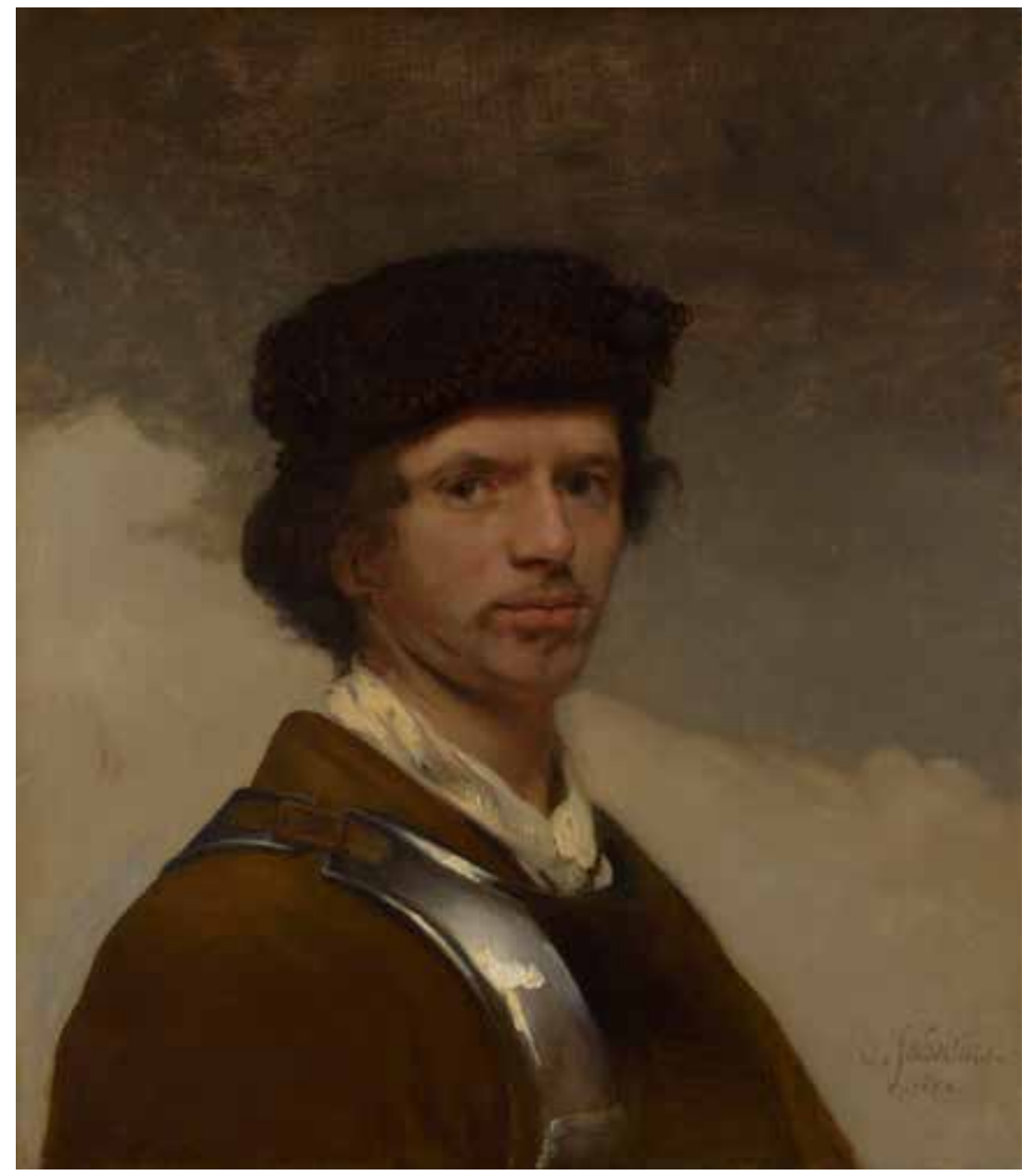

Fig. 1: Carel Fabritius, Selfportrait, 1654; The National Gallery, London All use subject to https://about.jstor.org/terms 


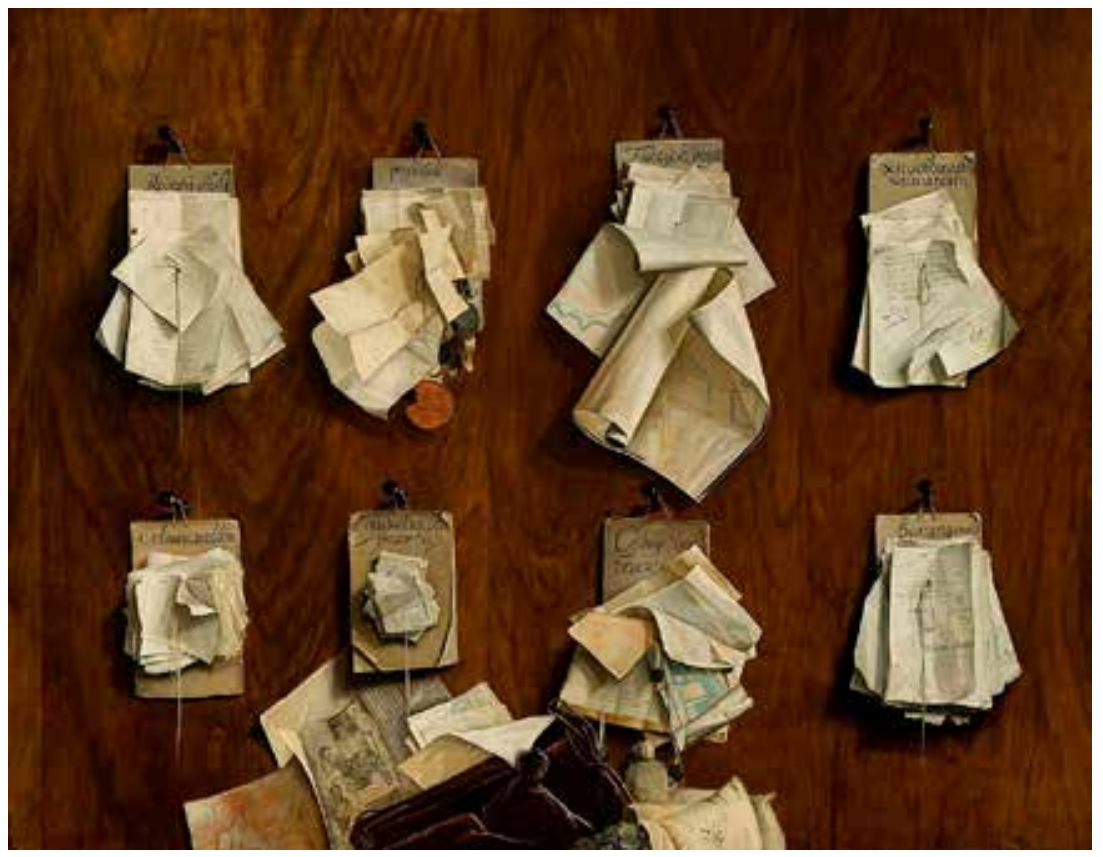

Fig. 2: Cornelis Brisé, Documents concerning the treasury of the city of Amsterdam, 1655; Royal Palace, Amsterdam

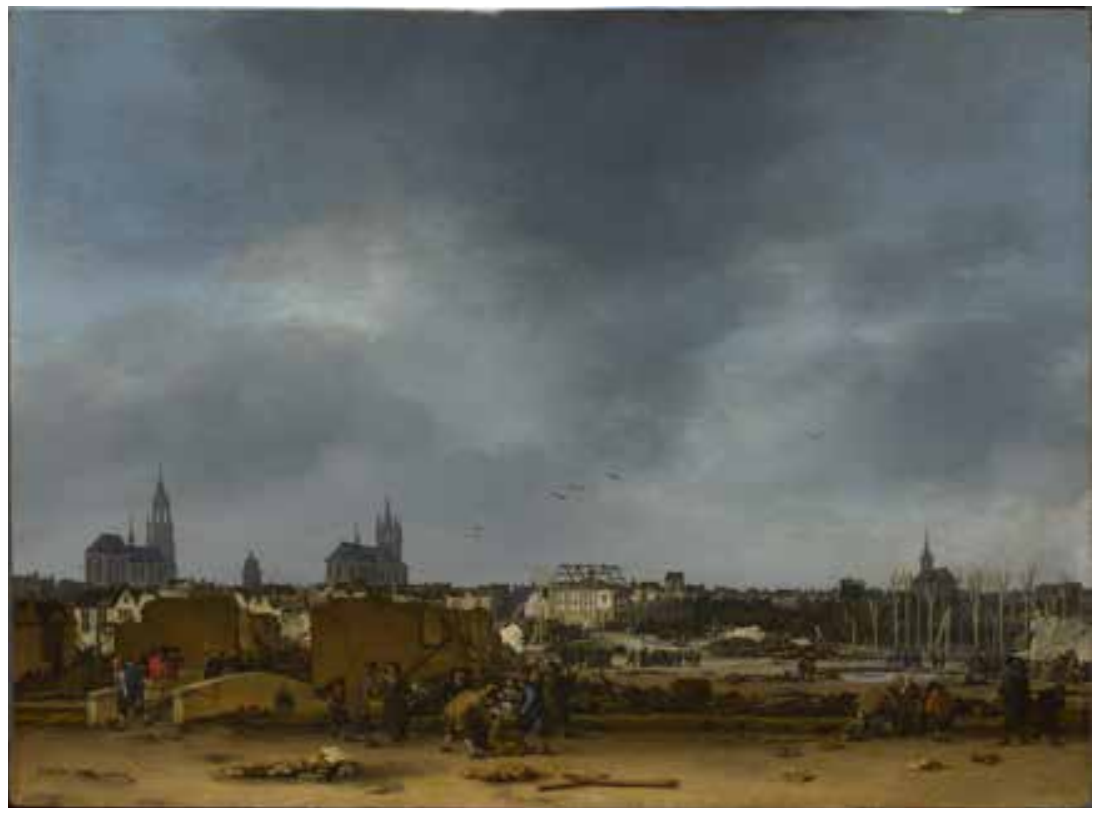

Fig. 3: Egbert van der Poel, View of Delft after the explosion, 1654; The National Gallery London 


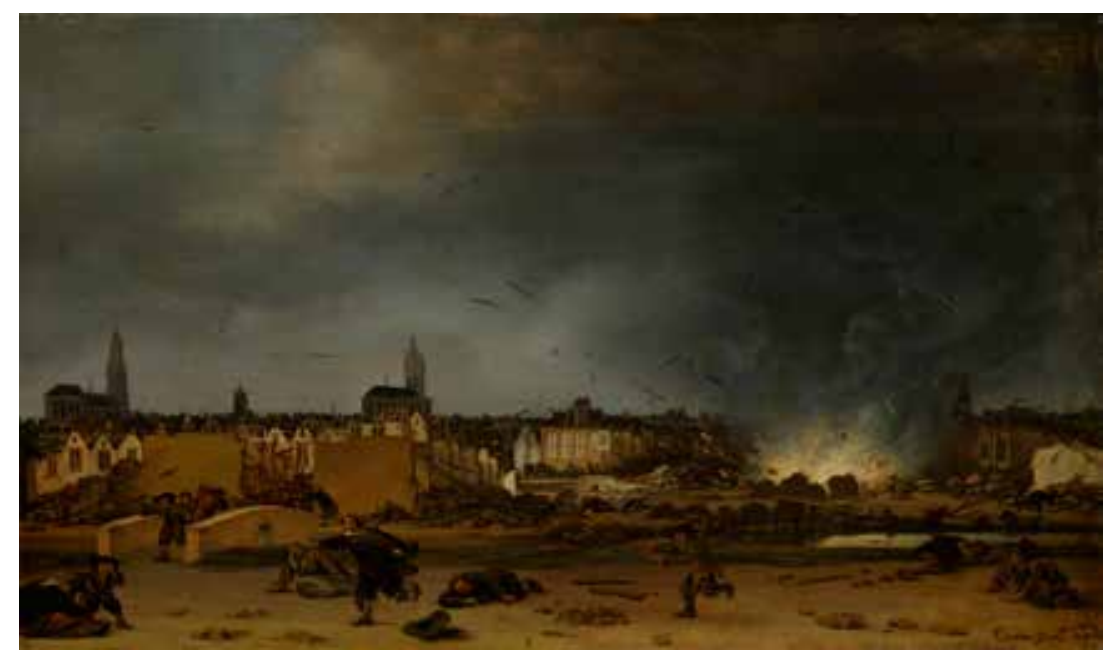

Fig. 4: Egbert van der Poel, View of the Delft explosion, 1654; Rijksmuseum, Amsterdam

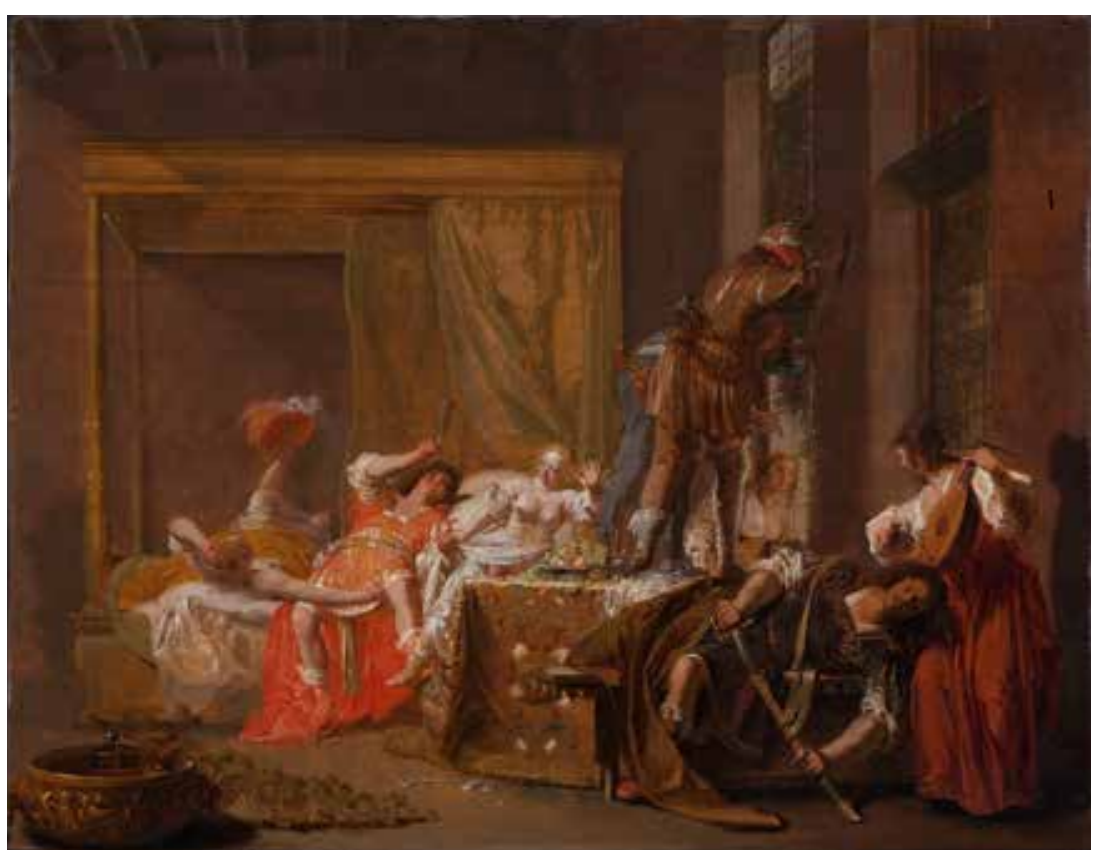

Fig. 5: Nicolaus Knüpfer, Scene from the marriage between Messalina and Gaius Silius, possibly an episode from a play; Rijksmuseum, Amsterdam 


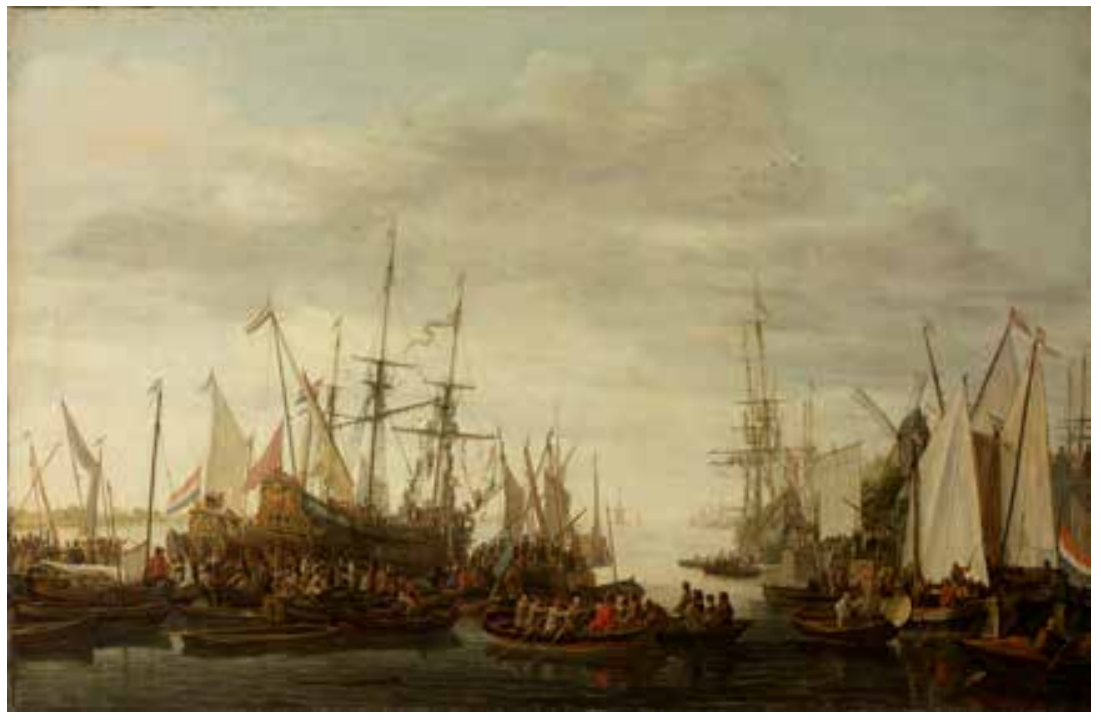

Fig. 6: Lieve Verschuier, The keelhauling of the surgeon of admiral Jan van Nes, 1600-1686; Rijksmuseum, Amsterdam

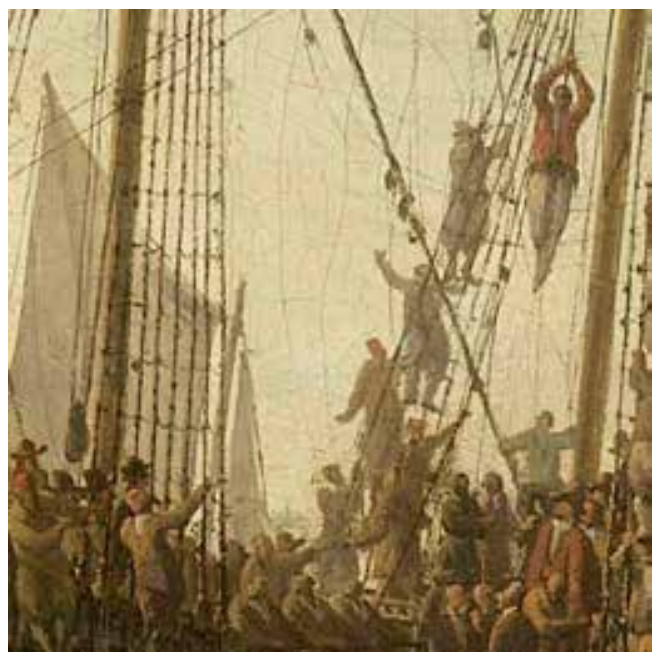

Fig. 7: Detail of The keelhauling of the surgeon of admiral Jan van Nes 


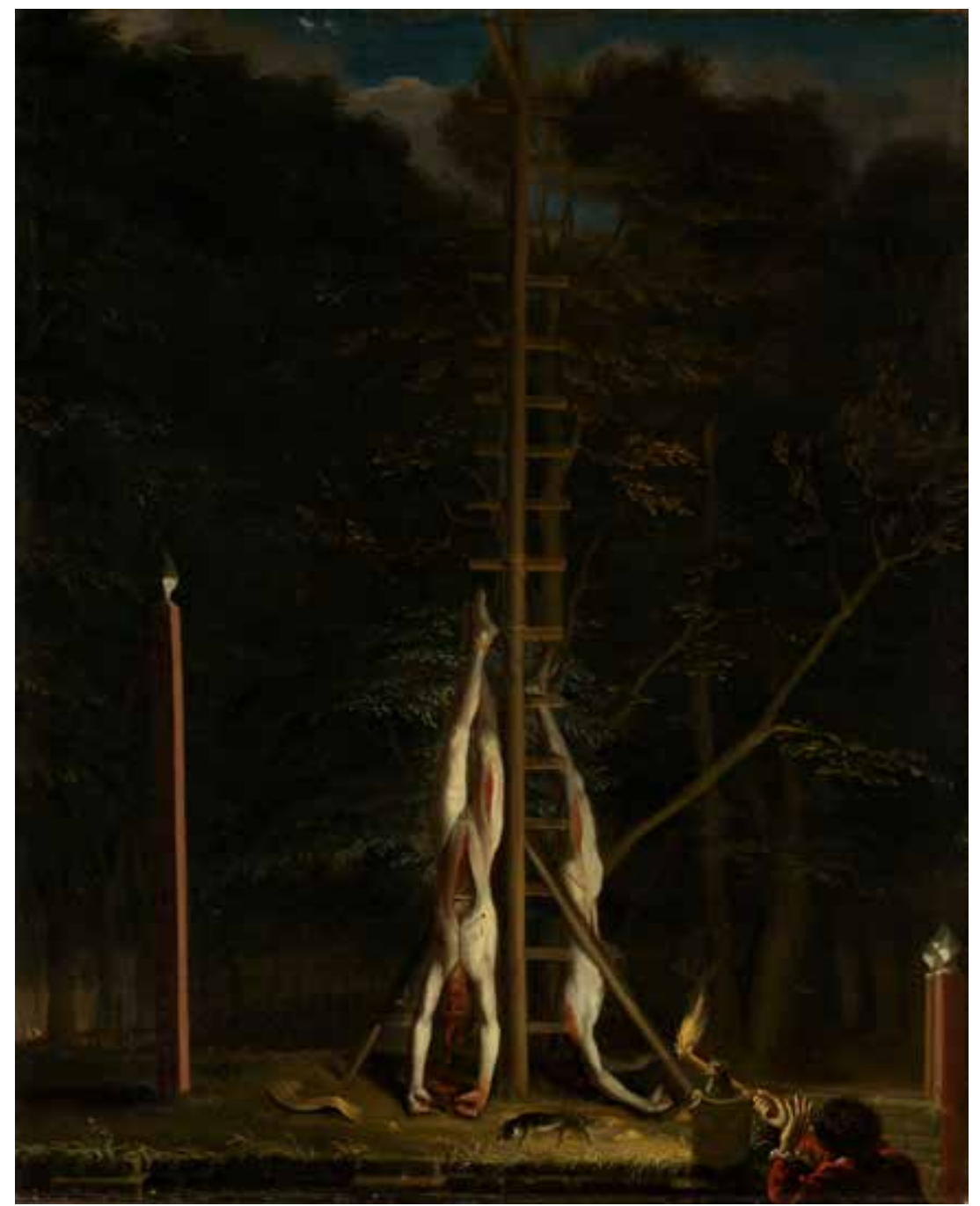

Fig. 8: Jan de Baen, The corpses of the brothers De Witt, 1672--1675; Rijksmuseum Amsterdam 


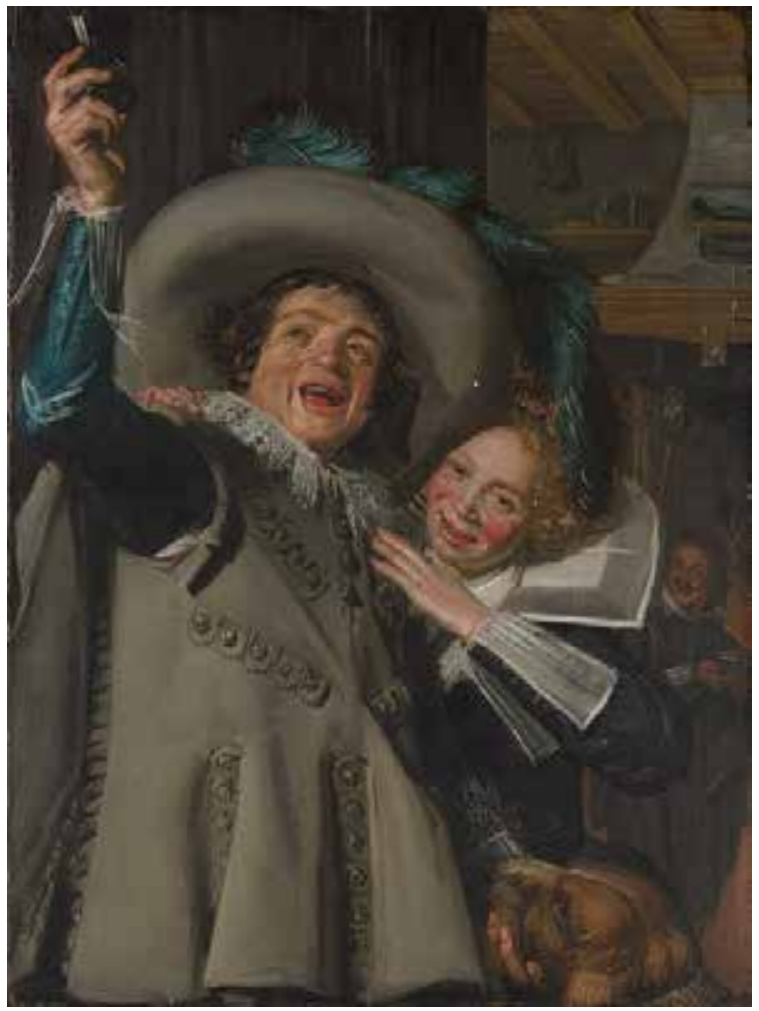

Fig. 9: Frans Hals, Young man and woman in an inn, 1623; Metropolitan Museum, New York 


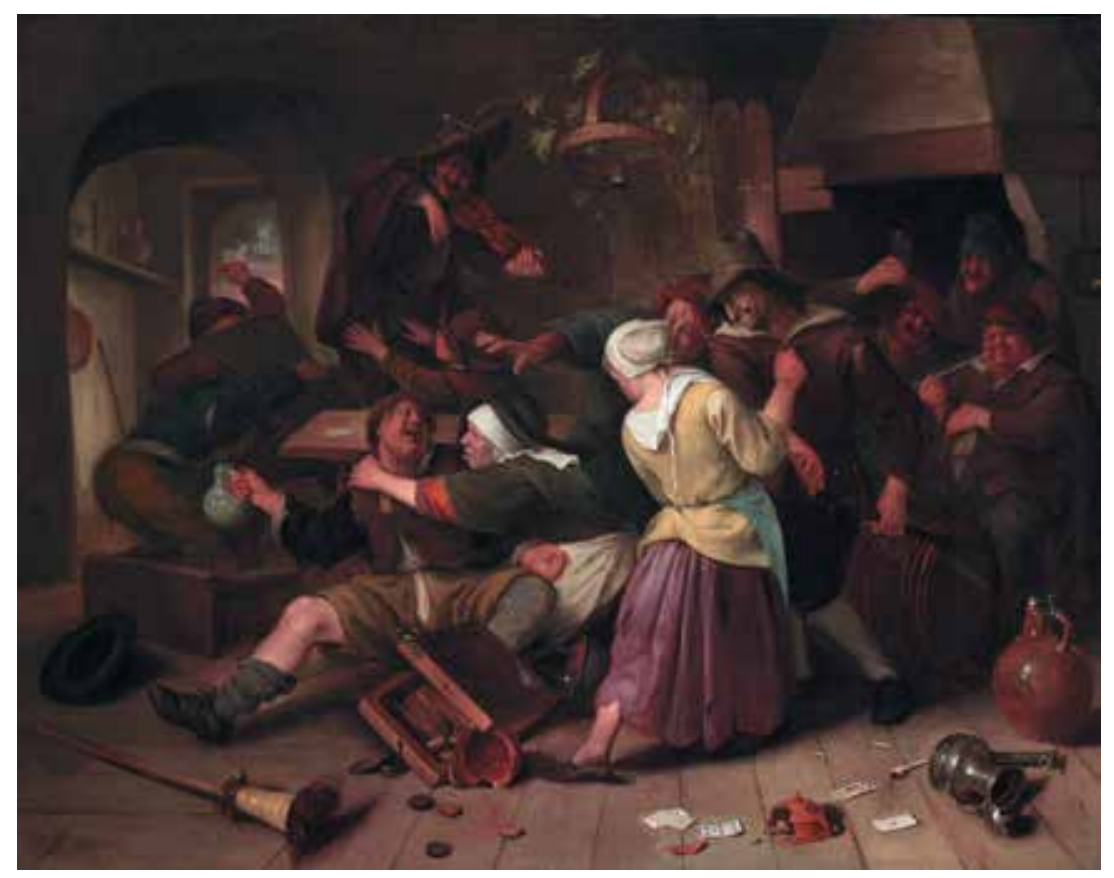

Fig. 10: Jan Steen, Gamblers quarreling, 1665; Institute of Arts, Detroit 


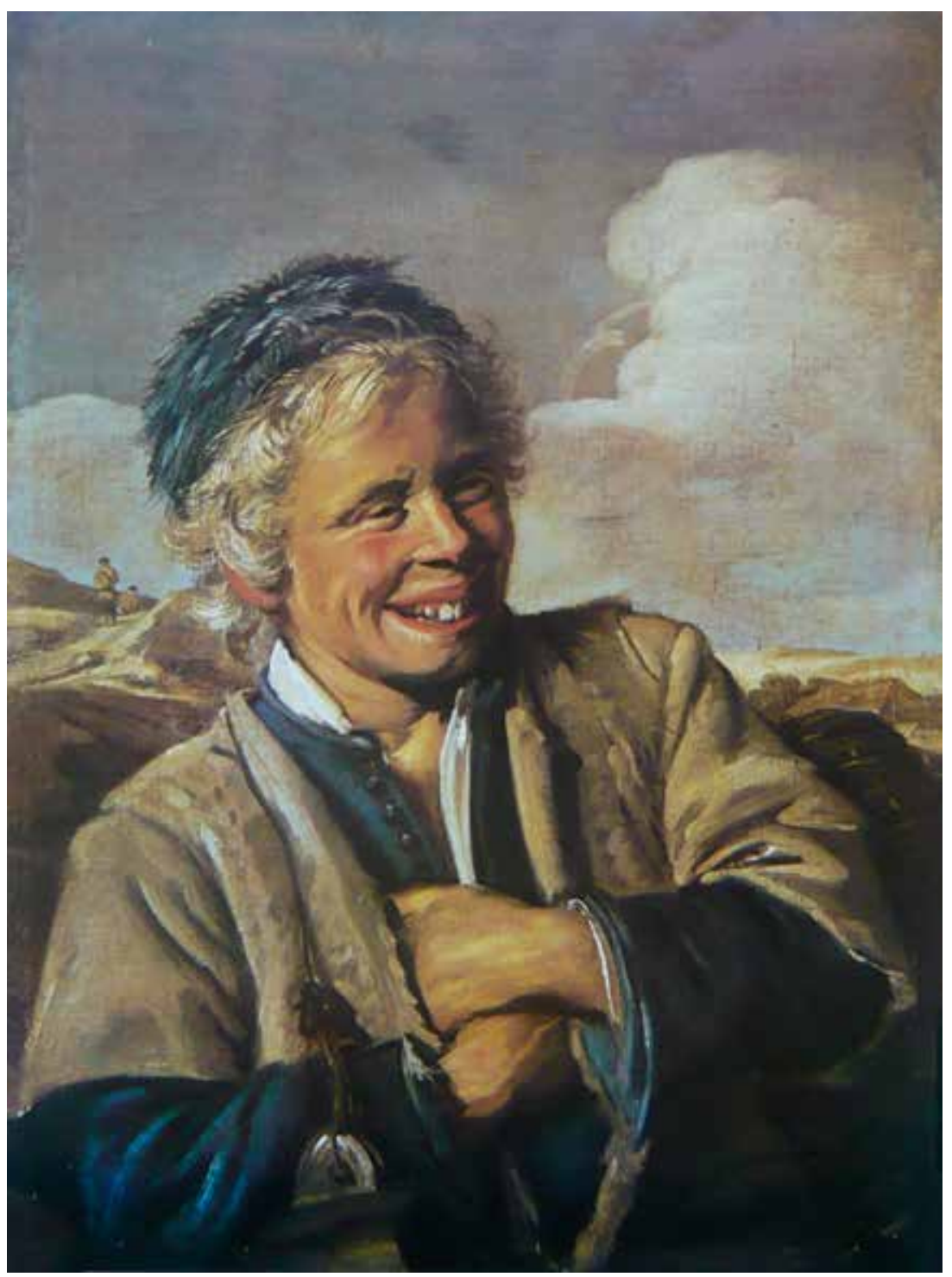

Fig. 11: Frans Hals, Laughing Fisher Boy, c. 1627-1630; Schloss Burgsteinfurt, Westphalia 


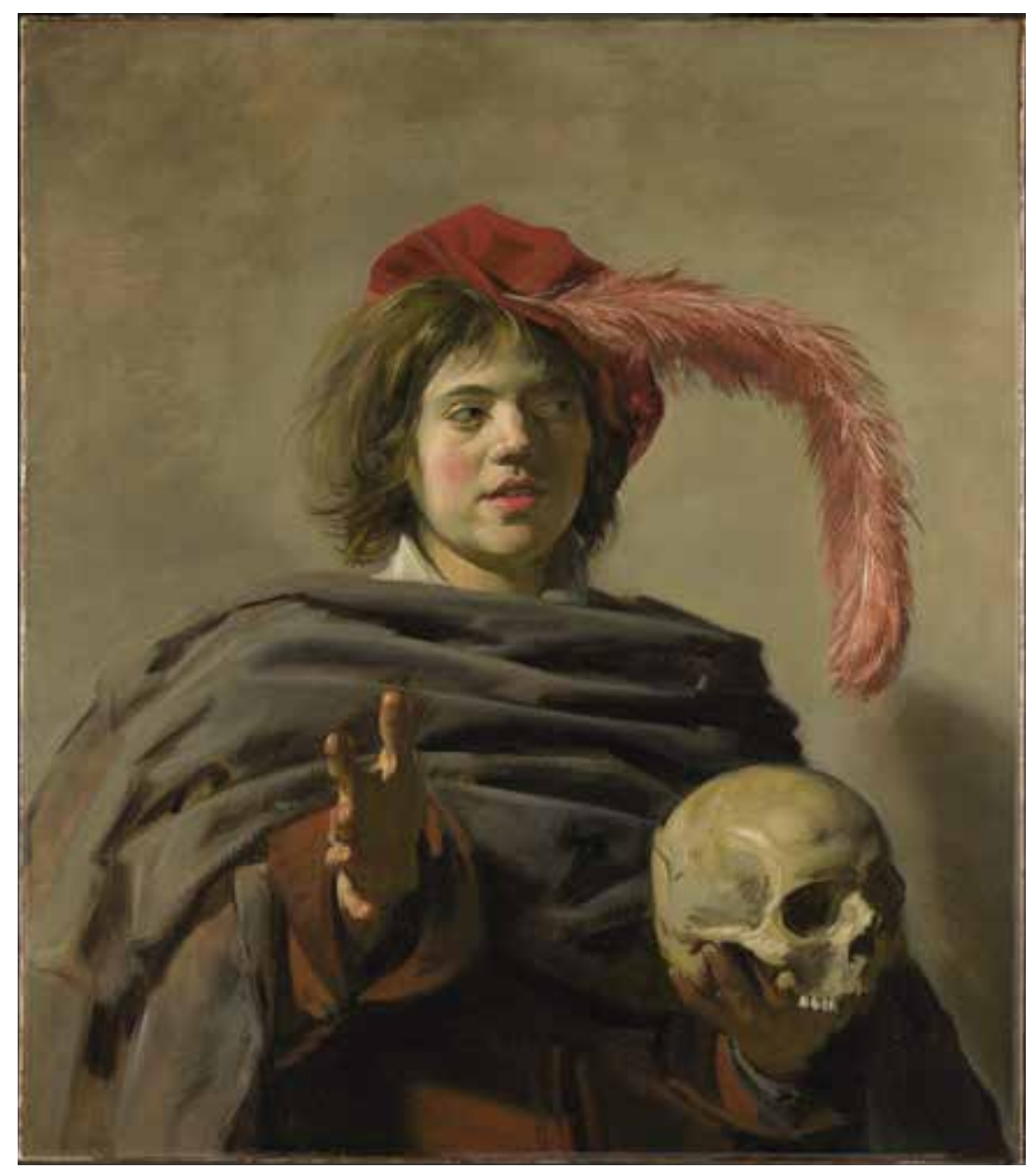

Fig. 12: Frans Hals, Young man with skull, c. 1626-1628; National Gallery, London 


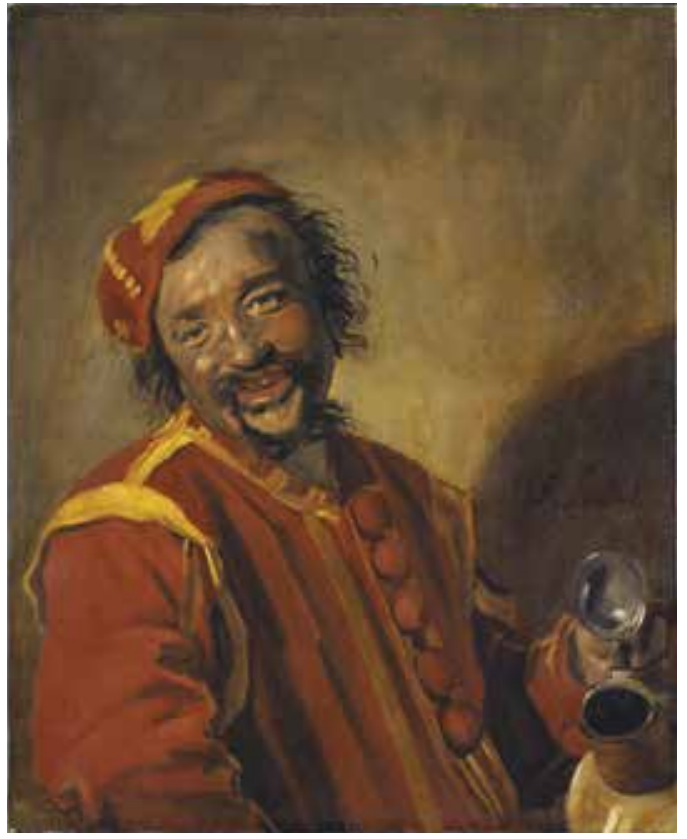

Fig. 13: Frans Hals, The jolly reveler, or, Peeckelhaering, 1628-1630; Gemälde Galerie Alte Meister, Kassel

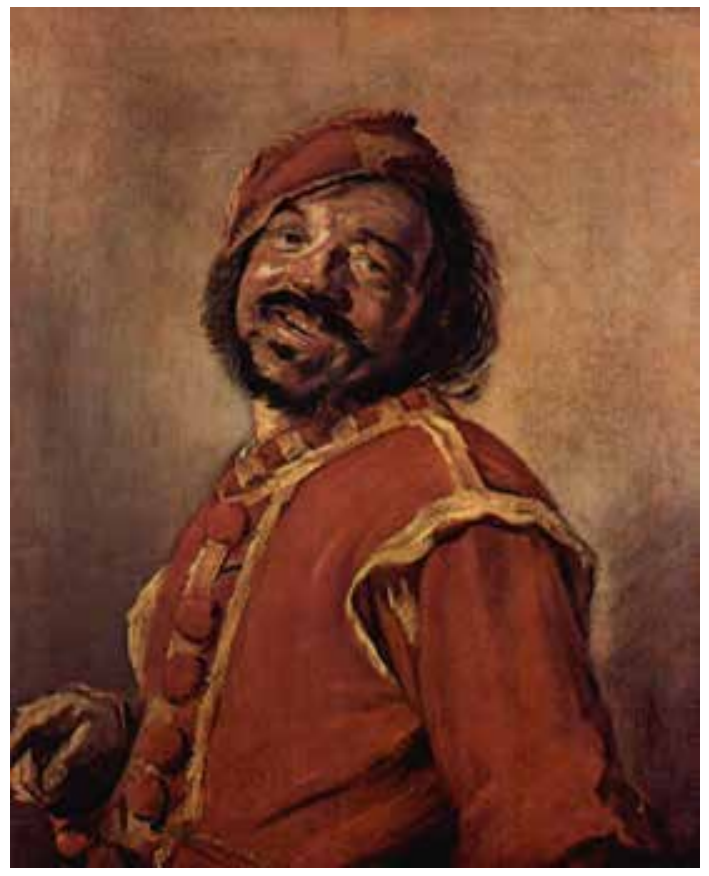

Fig. 14: Frans Hals, The mulatto, c. 1628-1630; Museum der Bildende Kunst, Leipzig All use subject to https://about.jstor.org/terms 


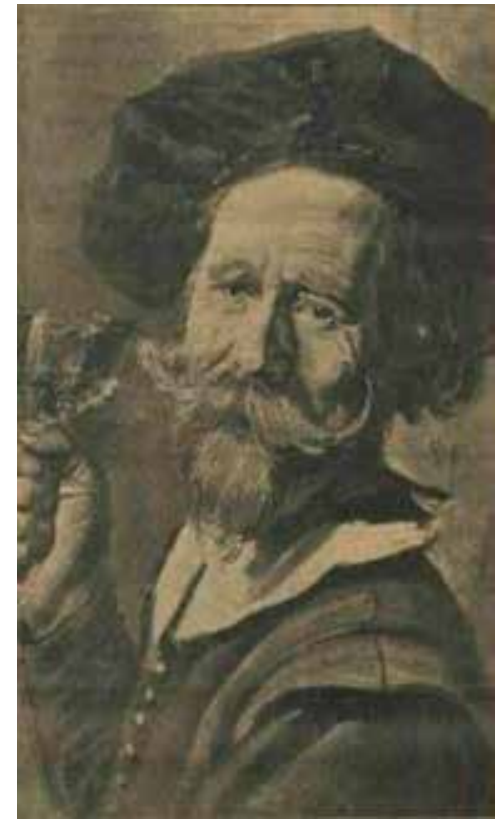

Fig. 15: Old photo of the painting Verdonck when it was still known as Man with a wine glass, before \& after photos published in an article in the Sumatra Post in 1928

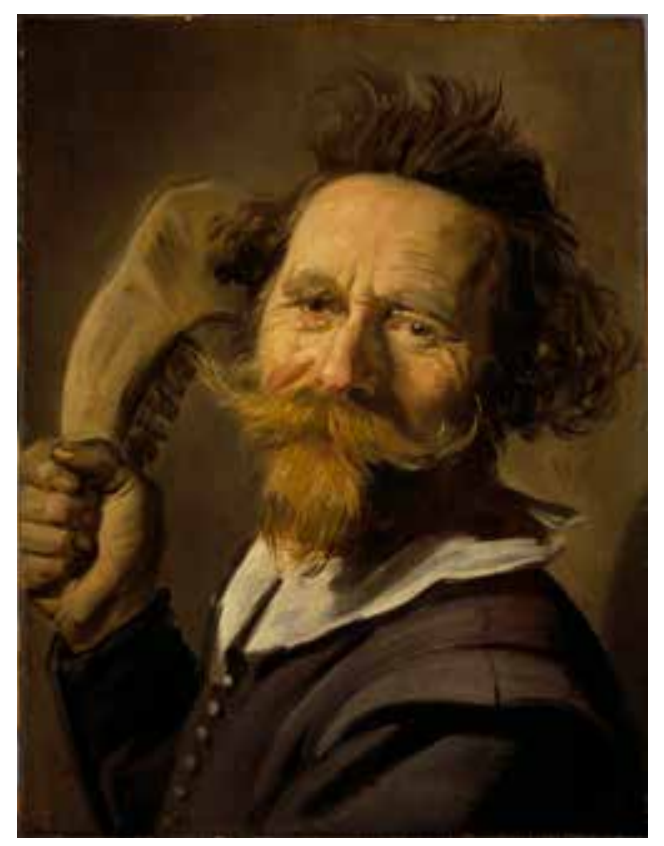

Fig. 16: Frans Hals, Verdonck, or Portrait of a man with a cow's jawbone in his hand, 1627; National Gallery, Scotland 


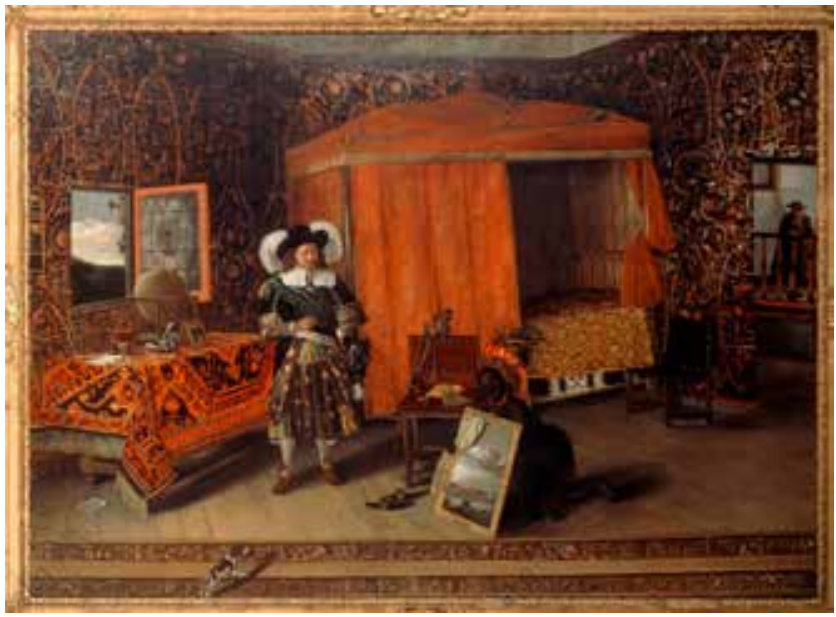

Fig. 17: Pieter de Wit, Portrait of Dirck Wilre, director-general of the West-Indian Company in the castle of St. George d'Elmina, 1669; Sotheby's, London

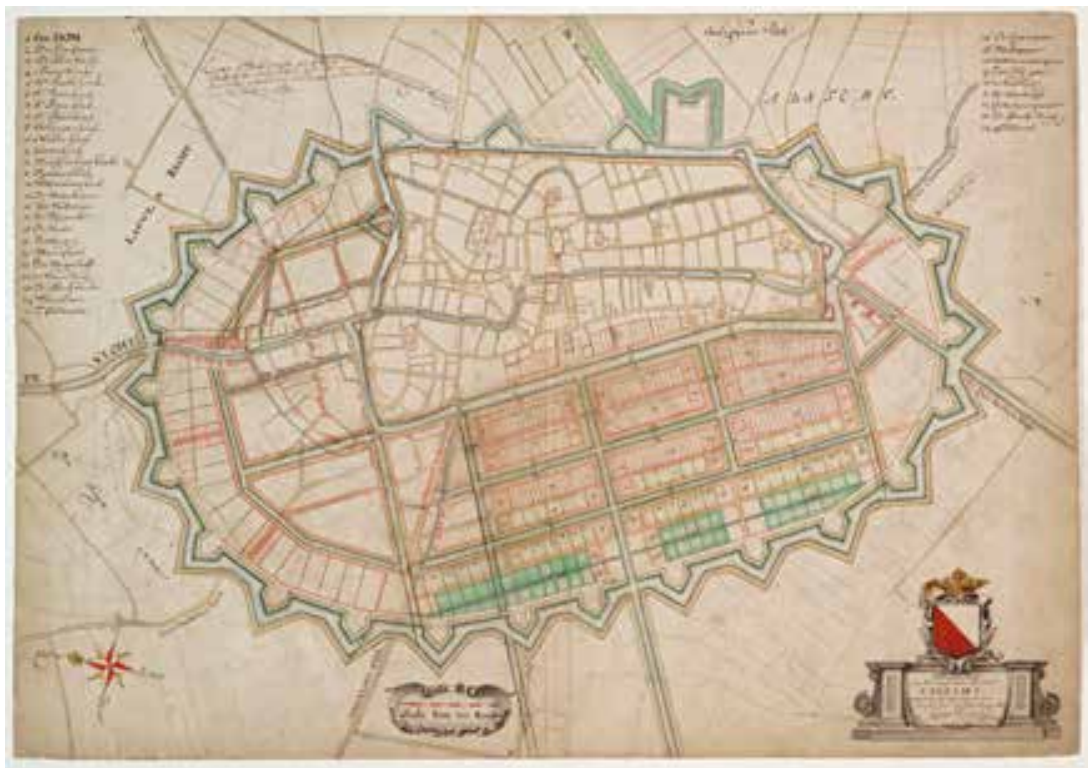

Fig. 18: Expansion plan of Hendrick Moreelse, 1664; Centraal Museum, Utrecht 


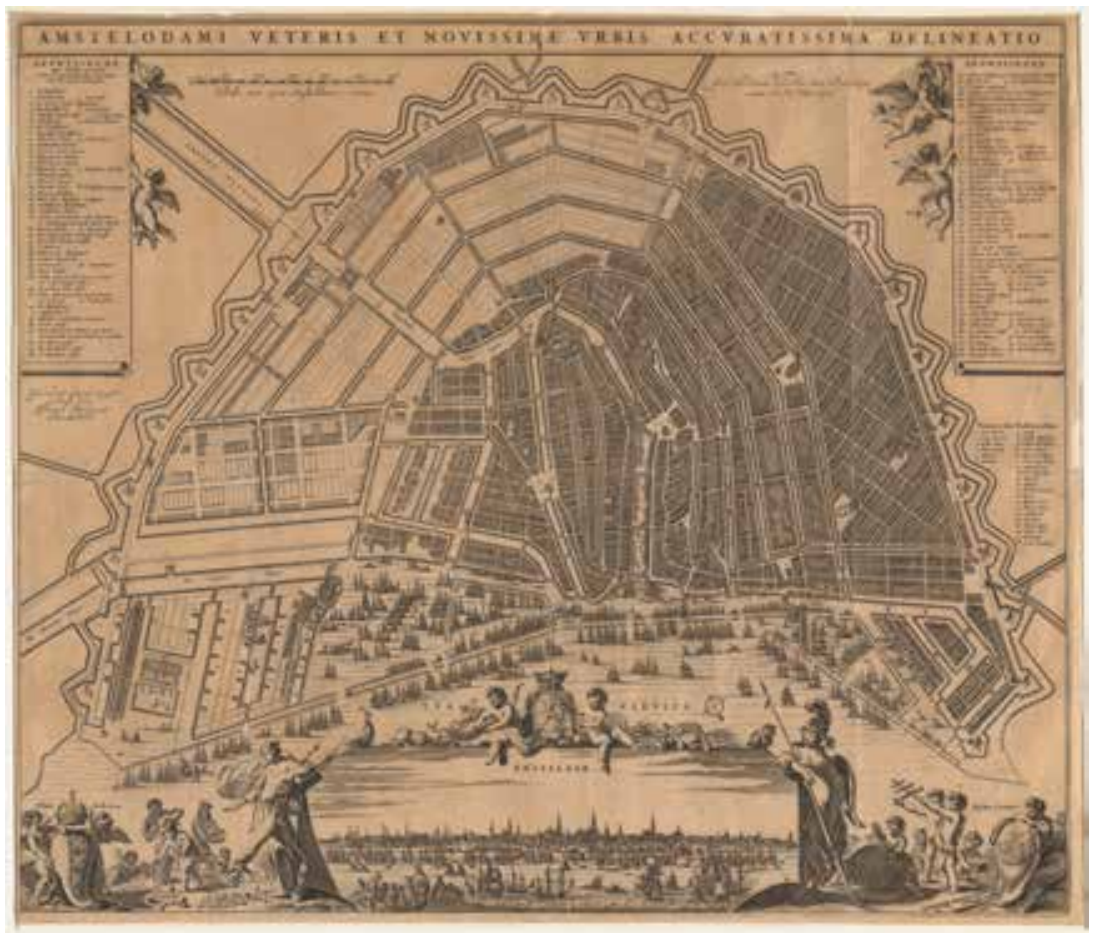

Fig. 19: Daniël Stalpaert, Depiction of the city - with its most recent expansion, 1665; Collectie Atlas Kok, Stadsarchief Amsterdam 


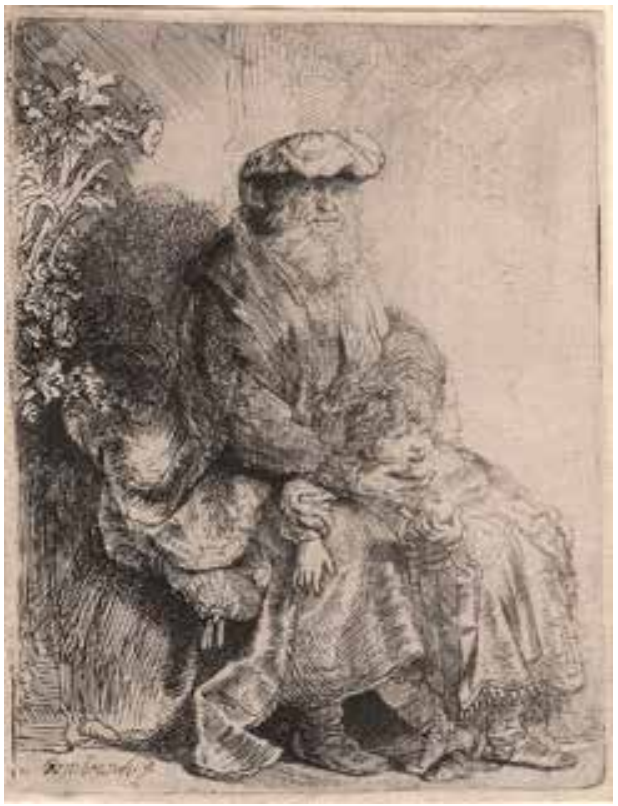

Fig. 20: Rembrandt, Father Abraham playing with his son, 1635-1639; Rijksmuseum, Amsterdam

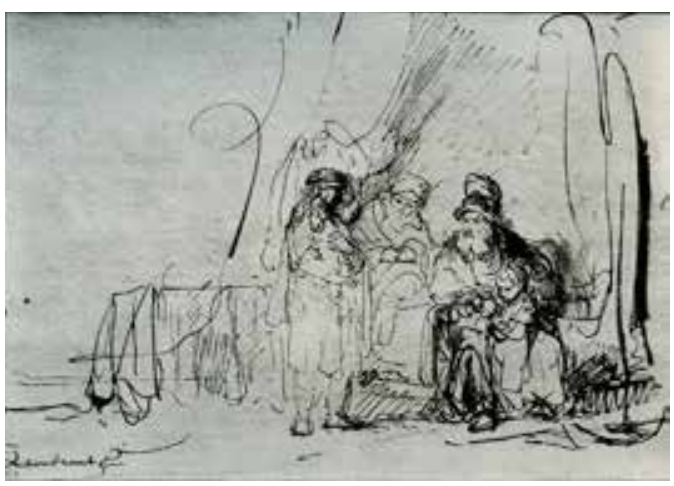

Fig. 21: Rembrandt, Joseph telling his dreams to Jacob, c. 1642-1643; Albertina, Vienna 


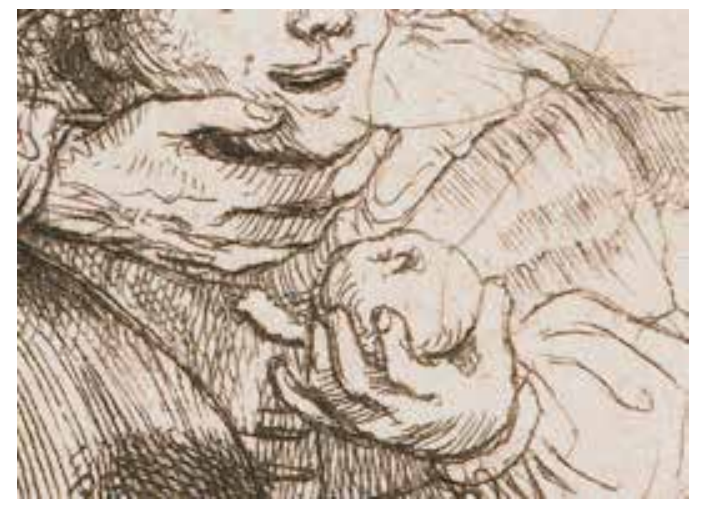

Fig. 22: Detail of hand and button, Rembrandt, Father Abraham playing with his son

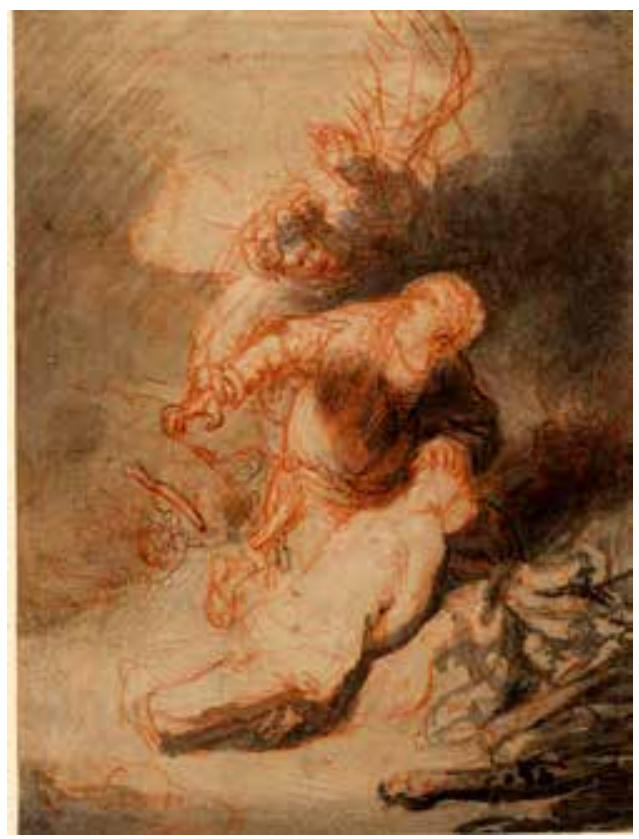

Fig. 23: Rembrandt, The angel stopping Abraham from sacrificing Isaac, 1635; The British Museum, London 


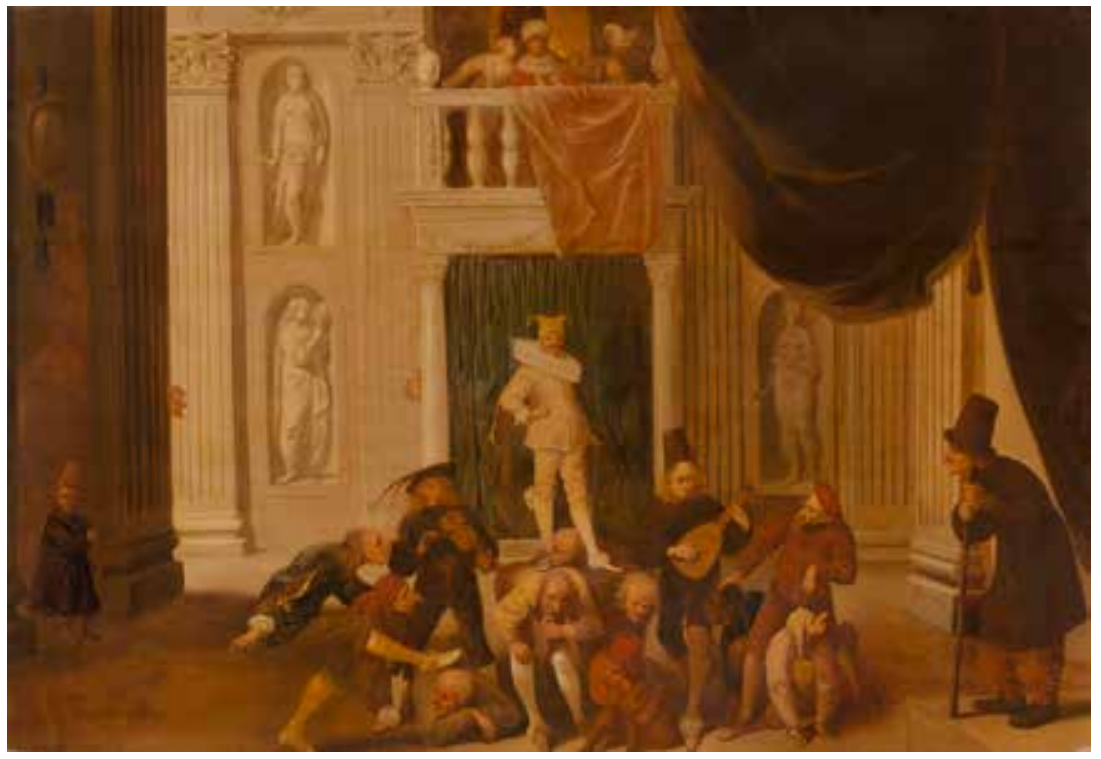

Fig. 24: Pieter Quast, The triumph of Folly: Brutus in the figure of a fool before king Tarquin, 1643; Maurits Huis, The Hague 


\section{Public theater, collective drama and the new - Van den Enden and Huygens}

\subsection{Theatrum mundi, public acting and the plane of collective imagination}

The conflict between the two dominant political parties in the Dutch Republic, orangists and republicans, was not just a political conflict within one and the same world. The two implied different worlds, different attitudes, and a different baroque. The same, of course, holds for the conflict between Protestants and Catholics, or between those who believed in God and those who flatly denied his existence. One of the figures in which all these tensions appeared to come together was Franciscus van den Enden (1602-1674), a remarkable figure in his own right as well as the teacher of Spinoza. The website about his person and work introduces him as: 'Former Jesuit, neo-Latin poet, physician, art dealer, philosopher, teacher of Spinoza, and conspirator against Louis XIV', ${ }^{314}$ It could have added: 'book-seller, founder of a revolutionary Latin School, playwright, stage-director, freethinker'. Although Van den Enden was clearly an energetic man, Louis XIV proved a bigger fish to fry. Towards the end of his life, his freedom of speech had become more and more restricted in the Dutch Republic, and Van den Enden travelled to Paris in 1671 to open up a Latin School again, just as he had done previously in Amsterdam. Here as well he would preach revolution, advocating a free democratic republic. He would also take part in the Rohan complot that aimed to remove king Louis. These conspirators were found out and, whereas the aristocratic ones were honorably beheaded, citizen Van den Enden was dishonorably hanged on 27 November 1674.

Van den Enden's ideas about the non-existence of God implied a radically new form of thinking about how human beings appeared to an Other, to others and to themselves. For centuries the theatrum mundi metaphor had been the dominant metaphor that defined how people thought of their appearance in the world, their appearance within the all-encompassing view of a supreme being. ${ }^{315}$ That metaphor came to lose its ground however,

314 The website is designed, developed, and maintained by Frank Mertens; see: http://users. telenet.be/fvde/index.htm?Home1, accessed 3 February 2017.

315 For the long history of this metaphor see Lynda G. Christian, Theatrum mundi; for its relation to the history of early modern theatre, see the work of, for instance, Erika Fischer-Lichte, History 
and three of Van den Enden's texts show as much. Two of them dealt with the New World, and the third was a school drama: Philedonius. All three demonstrate how Van den Enden was not so much concerned with human beings as the players on an earthly stage. He was more concerned with the pedagogical potential of drama in the private space of a public school, where worlds were to be found and explored anew. This exploration found its extrapolation in the real world of practical action.

With the Stoics, in classical Rome, the metaphor functioned to support stability. The turbulence of the world was just appearance to the man who was able to remain stable; his role in life was only one staged by other, divine forces. This classical conception changed in the Middle Ages. In light of the Catholic worldview, the metaphor came to indicate the second-hand, illusionary nature of earthly life as opposed to the real life of the heavenly hereafter. By extension, the earthly business of human actions was chimerical as opposed to the truth of the vita contemplativa. Human affairs were considered from the viewpoint of God, then, and this meaning of the metaphor lived on until the seventeenth century. ${ }^{316}$ But in the course of that century another meaning became increasingly important, which was that man staged himself socially or politicaly, before his fellow men. This meaning sprung from a growing consciousness of the fact that human beings had roles, and played them, in a world that was socio-culturally organized (a major point in Richard Sennett's The Fall of Public Man). Here it was not so much illusion as deception that characterized the dynamic; theatricality was equated with fraud and deceit.

In its historical context, Lynda Christian considers the theatrum mundi metaphor to have two different modes. There was the 'Stoic-NeoplatonicChristian' mode, where some form of divine logos framed a meaningful pattern within which human life would be staged and would have to be played out. Then, there was the satiric or Lucianic mode, with its more cynical view that life was folly and man 'the greatest fool of all' ${ }^{3{ }^{17}} \mathrm{~A}$ third mode, hinted at by René van Stipriaan, might be described as rhetoricophilosophical, where rulers used theatrical deceit in order to make the body politic work (in the final chapter 8 we will come back to this when dealing with a painting entitled The triumph of Folly: Brutus in the figure of

of European Drama and Theatre.

316 On this see Erika Fischer-Lichte, 'Theatrum vitae humanae.' History of European Drama and Theatre, pp. 50-144.

317 Lynda G. Christian, Theatrum mundi: The history of an idea, pp. 6o-61. 
a fool before king Tarquinius). ${ }^{318}$ This mode was propagated by figures such as Machiavelli and his Christian counterpart, Diego de Saavedra Fajardo. Theatrical deceit was used here in the service of a political order, to make people aware and make them judge. Especially in the context of the latter, this was why theater became less a vehicle of illusion and more an enlightening instrument, that could teach people how not to be deceived, or that could unveil how things really were. This mode would, at least in part, be pertinent to the establishment of the Amsterdam art society Nil volentibus arduum, founded in 1669 . In it, former pupils of Van den Enden and some others joined in an attempt to mobilize theater in a battle against superstition and illusion.

The public status of Van den Enden can be traced in his pupils and in what they did, but also in what others reported on him. For instance, while in the Netherlands the Danish scientist, scholar, and poet Ole Borch (or Olaus Borrichius), kept a diary. ${ }^{319}$ Around 3 and 4 April 1662 he wrote that a certain Joannes Alexandri had told him that:

...there are atheists here, predominantly Cartesians, such as Van den Enden, Glasemaker etc., who in turn teach others and although they do not proclaim atheism, since they often speak of god, they nevertheless understand God to be nothing else than the entire universe... ${ }^{320}$

This passage hints at the debates in the Republic around atheism or the nonexistence of God, with Descartes as the explicit common denominator and Spinoza as the elephant in the room. It was perhaps the most controversial and most feared topic of its time. It was also an issue of controversy and concern because radical thinkers appeared to teach, perhaps not a public activity in itself but one of great public interest and impact. This provokes the question of the precise nature of Van den Enden's public appearance and

318 On this, see René van Stipriaan, Leugens en vermaak, especially Part III, 'Ethos and Epistèmè' (pp. 157-230).

319 On this, see Olaus Borch, Itinerarium 1660-1665, vol. 2, p. 92. The quote can also be found on a site dedicated to Van den Enden, made by Frank Mertens of Ghent University, see Frank Mertens, ed., Online documents regarding Franciscus van den Enden. See also the 'Inleiding' (introduction) by Wim Klever to Franciscus van den Enden, Vrije Politijke Stellingen, especially pp. 27-28. On the broader context of the relations between Van den Enden, Spinoza, and Borch, see Eric Jorink, 'Outside God there is nothing'. Van den Enden is also an important figure in Israel's Radical Enlightenment.

320 In the original: 'Esse hîc atheos, eosqve potissimum Cartesianos, ut van der Enden, Glasemaker etc: qvi et alios subinde edoceant, non qvidem profiteri eos Atheismum, loqvi crebrò de deo, sed per Deum nil aliud intelligere qvam totum hoc universum...' 
performance. Did he stage himself? Could his acts be understood in terms of one of the modes of the theatrum mundi metaphor, especially the third rhetoric-political one? Or should we consider them rather in dramatic terms?

Reflecting on the Early Modern societies in Europe, Arjan van Dixhoorn calls such societies theatrical because they were full of theatrical events. He defines them as follows:

This means that a situation becomes theatrical as soon as an audience perceives an act as intentional and recognizes the accentuated movements and speech as interactions between performers and spectators. In sum: events oriented towards public show and recognized as such are theatrical events. ${ }^{31}$

Here, Van Dixhoorn follows a study by Walter Prevenier and Wim Blockmans, who in turn derive their ideas on a 'theater state' from the work of anthropologist Clifford Geertz..$^{32}$ Yet, when Geertz's idea of theatricality in nineteenth-century Bali is taken up and applied to Western societies from Early Modern times, there is not only the risk of equating exotic and so-called primitive societies with early Western societies, there is also the risk of ignoring intrinsic and specific relations between power and theatrical display.

In the discussion around the theatrical status of Early Modern society one almost inevitably encounters the interchangeable use of notions such as theater and spectacle, ritual and show, display and performance, ceremony and farce, a mass in church and a performer singing a song in the public square, a coronation and a court of law, an execution and the public performance of a tableau vivant. All these different forms of public events fall, as Van Dixhoorn argues, under the umbrella of the 'theatrical'. To be sure, all these public acts have theatrical aspects, and they all imply forms of performance. But then again, what made one event theatrical instead of ritual, theatrical instead of spectacular, or more theatrical than ceremonial? And what was the relation of theatricality to power? Calling Early Modern states theatrical is definitely to the point, but it is important to define the specific kind of theatricality at stake in these states, as opposed to in, for instance, the classical Greek city state, nineteenth-century

321 Arjan van Dixhoorn, 'Theater Society in the Low Countries'.

322 Clifford Geertz's Negara: The Theater State in 19th Century Bali was published in 1980. The study by Blockmans and Prevenier was entitled The Burgundian Netherlands. On its influence, see for instance Graeme Small in his 'Introduction to the 2002 edition' of Richard Vaughan's Philip the Good, pp. xix-li, esp. p. xliii. For an important early survey of studies into the early modern theater state, see also Peter Arnade, Realms of Ritual. 
Bali, or seventeenth-century Dutch society. In Geertz's pre-colonial and non-Western nineteenth-century Bali, for example, the aim of power was to serve the realization of ceremony and ritual, in contrast to classical Greek city states where theatricality was central to both the anthropological and political organization of society.

John J. McGavin's idea of a 'dramaturgical society' — from his study on texts by late medieval and Early Modern Scottish chroniclers-is noteworthy in this context. By defining late medieval or Early Modern society as dramaturgical, McGavin highlights how people were constantly preoccupied with how their actions would read as a performance or, rather, as being scripted. McGavin consequently distinguishes 'dramaturgical' from 'theatrical', with the latter emphasizing the role of the visual and of the public. The first emphasizes the dual positioning of people as both performers thinking about how to perform things and audience members looking at something in the sense of looking for something: they were consciously and self-consciously 'reading' what was being performed..$^{23}$ If we take this to apply to Van den Enden we need to note first that relatively few people had actually met him or his former pupil, Spinoza. There were few who had actually heard them speak or had even read themselves what the two had expressed in writing or in print. Make no mistake though: Van den Enden and Spinoza were both very much concerned with how they appeared and, in this sense, fit the dramaturgical model of McGavin much better than Van Dixhoorn's theatrical one. Interestingly, although he was very much concerned with how he appeared and how he was read, Spinoza was not that active as a public figure. On the contrary, he shunned the public. Considering how dangerous his writings were, his preferring a situation of anonymity may have been justified. Yet, he was very much alive in the public imagination. Could this collective imagination, then, be the 'space' in which — or the plane on which-Spinoza's performance would take place?

It was the disturbance of collective imagination that had brought authorities to act against Van den Enden in 1665, when he published Free Political Propositions and Considerations of State..$^{32}$ This controversial text was conceptualized between 1661 and 1662, when Van den Enden was acting as the mediator between a group of Dutch citizens who wanted to emigrate

323 McGavin falls back especially on an article by Peter E.S. Freund, 'Social Performances and their Discontents', in the broader context of performance theory as developed by Erving Goffman and Richard Schechner. John McGavin, Theatricality and Narrative in Medieval and Early Modern Scotland, pp. 15-16.

324 In the original: Vrije Politijke Stellingen, en Consideratien van Staat, published in English as Free Political Propositions and Considerations of State in the translation by Wim Klever. 
to the New Netherlands and the administrators of the Chamber of Colonies in Amsterdam who had to give their permission. ${ }^{25}$ The New Netherlands were located in Northern America, on the South River (currently Delaware), and Van den Enden, being their mediator, had written a short treatise on the region. In it he not only described the land and its inhabitants but also expressed his vision of a new kind of society there. The text was printed in 1662 as part of a collection of documents under the title Brief Account of New Netherlands' Situation, a collection that was the result of Van den Enden's acting as the spokesman for the group of Dutch citizens. ${ }^{326}$ As such, he had written several requests and proposals that he had defended in conferentien (meetings) with the members of the Chamber. The latter were greatly troubled by the sketch Van den Enden gave of this new society. It would consist of individual free men who had the right to bear arms so as to be able to defend their freedom. They would govern themselves democratically by means of mutual consultation in a society that knew no organized form of religion. This would require free speech in the most principal and radical way. In this context, one of the most controversial points was surely the prohibition of all priests, preachers, vicars, etc.. They were excluded because they could not live with the idea of radical free speech and would only cause unrest, according to Van den Enden.

The Amsterdam authorities, having learned about all this, were not amused and would not allow it. This is what brought Van den Enden to add yet another text to the growing collection: an allegory entitled Na-Reeden ('Afterword') in which he espoused a radically new form of state organization. Having had enough of his insistent requests and being troubled, especially, by this last explicit form of criticism, the authorities gave Van den Enden a disputatieverbod in 1662: he was no longer allowed to speak publicly about the issue, most likely due to the atheistic nature of the new society and new world he had sketched. ${ }^{327}$ Despite this prohibition, Van den Enden decided to work out his vision systematically in the following years. He wrote a work that consisted of three parts: the first part was the already mentioned Free Political Propositions and Considerations of State, the second part dealt with the true interests of the Dutch and how these should be served politically, and the third part dealt with the construction of the Republic as a confederation of cities..$^{23}$

325 On all this see the 'Inleiding' by Klever to Van den Enden's Vrije politijke stellingen.

326 The original text of Kort Verhaelvan Nieuw Nederlands Gelegenheit can be found here: http:// www.wdl.org/static/c/4065/service/4065.pdf. For an English translation, see Van den Enden, Free Political Propositions and Considerations of State (1665).

327 The source on this prohibition to speak is again Borch, Itinerarium 1660-1665, vol. 2, p. 92. 328 Van den Enden, Vrije politijke stellingen, pp. 129-130. 
The majority of these texts were not published. Yet this did not mean the content of the manuscripts was unknown. The previously mentioned Borch also wrote about how he had heard that 'Van den Enden has handed certain manuscripts intricate with the secrecies of his philosophies to certain friends .... ${ }^{329}$ Via what Borch had heard, Van den Enden 'comes to life' as a person and as a body of work, and as a result a conversation or debate was fueled again. Moreover, Van den Enden is not described here because of how he performed, but because of what he did. This suggests the public debate was not that public at all, but took place via circles or chains of friends and acquaintances who would tell one another what was going on. The paradox of course is that 'what was going on' was people talking about what was going on. This was obviously much more than mere talk, or language. The actors concerned came to life, dramatically, because of what they had done. Thus, they did not appear so much as actors on a stage but as imaginary yet real figures acting dramatically. In light of all this, the diary of Borch testifies to a specific kind of collective plane that was also individual, both private and public, fueled by talking in private spaces, or in any spaces where people might read, hear, and discuss things. Van den Enden became an actor in Borch's head (and diary), together with others who participated in the debate on atheism. That is to say: when Van den Enden was prohibited from speaking in public on the issue of atheism, the debate stopped as a public performance but was continued dramatically. In a sense, the prohibition may well have intensified it on this plane of collective imagination.

Partly, then, Amsterdam was an example of Early Modern theatricality in the churches, in the squares and streets connecting the urban interior with the contact zone of the harbor. At the same time it allowed new forms of public meeting and theatricality to come into being such as in the new theater, the new city hall, the new bourse. There was also an architectonics of an internalized yet collective plane, however. Here, some form of dramatization was at stake, in the sense that actors did not appear on some sort of stage. Rather they took part in dramatic actions on the plane of collective imagination.

Still, Van den Enden also acted on the newly established public stage of the Amsterdam theater. He produced and wrote school dramas that were eventually performed there; dramatically acted out first in the privacy of the school, they were then made public and staged in the theater.

329 Olaus Borch, Itinerarium $1660-1665$, vol 2, p. 92. In the original: 'Van den Enden qvædam philosophiæ suæ arcaniora communicâsse qvibusdam amicis manuscripta...' See also: http:// users.telenet.be/fvde/SourcesP/Borch_04_1662.pdf 


\subsection{Speaking for those who understand: a school drama in a theater}

The school dramas produced and written by Franciscus van den Enden are of interest because they functioned in different architectural spaces. As instruments in Van den Enden's pedagogical endeavor at his Latin School, the plays functioned in a space connected to both teachers and pupils. In several instances, however, they moved into the public urban space, and more specifically into the Amsterdam city theater. Philedonius, for instance, a play in Latin, was performed twice in the city theater in 1657 , probably for a select audience. ${ }^{33^{\circ}}$

The play is influenced by the medieval genre of the esbattement, which in turn was inspired by the tradition, by scholastic or dialectical reasoning. It is organized into three acts. These are not subdivided into scenes, however, but in 'Uitkomste' ('Results' or 'Conclusions'). In the three acts there are respectively eight, four, and nine of these 'conclusions', which are the result of argumentative encounters or internal considerations. Philedonius starts out by stating that his luck or well-being exceeds that of kings or heroes, is higher than the power of fortune, and makes him god-like. He goes on to encounter a series of characters who either try to teach him otherwise or tempt him to persist. First of all, there is Prudence, who would like to teach Philedonius that there is only one God whom one should fear. Yet Prudence is countered by Abundance, Honor, and later even Lust, who would like to teach Philedonius how to enjoy life. In the end Mercy brings him back to the lap of the Christian worldview, with a final argument between Body and Spirit. All these final considerations take place, tellingly, in Philedonius' dreams. These have taught him a final truth, as a result of which he can come to a final conclusion, which is that he repents his former ways and promises to lead a better life.

There is a praise poem by Vondel on the leading actor in Philedonius. ${ }^{3{ }^{31}}$ The subtitle of Vondel's praise poem indicates that it concerns the performance

330 Fairly little has been written on Philedonius. For an overview, see Mertens, ed., Online documents regarding Franciscus van den Enden. It is surprising that scholars so far have not been looking at the relation with Lucretius' De rerum natura.

331 The title of the poem is: 'Tooneelkrans voor den E. Jongelingk Nikolaes van Vlooswyck, toen hij de rol van Filedonius of Lusthart, bij Dr. Franciscus van den Enden op 's Wijzemans spreuck door zijne Latijnisten ten tooneele gevoert, zoo loflijck en stichtig uitbeelde' ('Theatre-crown for the honorable young man Nicolas of Vlooswyck, when he depicted so praiseworthy and didactically the role of Philedonius or Lust-heart, put on stage by dr. Franciscus van den Enden's Latin students according to Wiseman's aphorism'). Vondel, WB, VIII, pp. 570-71; http://www. dbnl.org/tekst/vondoo1deweo8_01/vondoo1deweo8_01_0181.php\#182. On the relation between Van den Enden and Vondel, see J.F.M. Sterck, Hoofdstukken over Vondel en zijn kring, pp. 65-67. 
by the young Nicolaes van Vlooswijck. Considering that the young actor was one of the sons of burgomaster Cornelis van Vlooswijck and his wife Anna van Hoorn, Vondel may well have been praising the son not so much for the content of his role but because of his status and future function in society. Perhaps he also knew all too well how his fortunes could depend on a burgomaster's family support (he would be supported by Anna van Hoorn financially, and would dedicate his play Jephta to her in 1659). The title of the play itself is translated by Vondel as 'Lusthart'. This may be derived from the short Dutch introduction provided for the general audience by Van den Enden himself. Yet, strictly speaking, Philedonius means 'the friend of hèdonè'. Since Van den Enden described himself — next to being the leader of the Latin school—as a philosopher, he would have been familiar with the meaning of philo, just as he must have been familiar with the work of Epicurus. Moreover, the resemblance between Philedonius and Philodemus is close and perhaps not coincidental. Philodemus of Gadara (c. 110-40 BCE) was a somewhat obscure Epicurist philosopher and poet whose writings, in the form of epigrams, were known via the Anthologia Graeca (some of his work would be recovered in the eighteenth century). The epigrams were all love poems or erotic ones.

Given this almost explicit yet hidden Epicurean context, it is telling that the major aim of Van den Enden's ideal state sketched a decade later, in between 1662 and 1665 , was that it took care of the people's 'well-being'. This was, indeed, the meaning of hèdonè before it was deformed into 'lust' by the Christian tradition, within which the work of Epicurus was despised. So, Philedonius would be the 'friend of well-being' for the well-informed, and for the even better informed might be a reference to Philodemus. For the more orthodox Christian it would mean 'he whose heart tends toward lust', which is the equivalent of 'Lusthart'.

With respect to both the social status of the burgomaster's son and the content of the play, and by implication Van den Enden and his school, Vondel's poem ends ambiguously:

Wisdom is one and the same, teaching In means disparate/diverse. Wisdom speaks

In church, school and theater: here lacks,

Neither tongue, nor speech. She can also work silently

In man's heart, and preach by mute signs:

Because letter, paint, and print indicate her sense, And depict her aim for intellect and eye.

She threatens and invites by punishment and reward, In painting or live tableau vivant 
Of good and evil, each to its disparate nature,

Which straightens those that are wandering, giving new birth.

Likewise your youth should unfold, like a flower,

And use life's spring to the welfare of the citizens.

One who can smother snakes so early,

Will outgrow the school, and become a worthy state-man. ${ }^{32}$

Vondel moves with care, that much is clear. Nicolaes van Vlooswijck was not the only burgomaster's child at Van den Enden's school; several sons and daughters of the Amsterdam elite were enrolled. So if there are unfriendly details in Vondel's text they should not be too explicit. In line 1, Vondel begins by saying that wisdom is 'one'. This accords with the idea that Christian wisdom is 'one' (although of course this was the cause of fundamental debates). Vondel then adds: 'teaching is diverse in means'. This may point to the fact that wisdom can be expressed and taught by different means: in church, school, theater, or by literature, painting, etc. Yet, the words are too ambiguous. Verscheiden may mean 'differing' but can also mean 'disparate'. The noun middelen ('means') may indeed be a noun, but it may also be a verb, and then it means 'to take a middle road', 'to negotiate'. In its most radical sense, the entire sentence then becomes: 'Wisdom is one and the same; teaching, in negotiating, is disparate'. This would not just be any teaching of course; it would be Van den Enden's.

Especially line 3 is telling. We have just learned that wisdom, in being one, speaks in church, school, and theater. Then Vondel ends line 3 with hier ontbreekt ('here lacks'). The enjambment suggests that such wisdom is lacking, although the 'here' is later filled in, by specifying that wisdom 'lacks neither tongue nor speech.' Still, the 'here lacks' stands, and is reinforced when Vondel immediately proceeds to say that wisdom may also speak silently, by mute signs. Why would he make this move if the poem is aimed at praising an actor performing a play that consisted predominantly of speaking? The sentence 'Here lacks neither tongue nor speech' may start

332 Vondel, Toneelkrans Voor den Edelen Jongkhere, Nicolaes van Vlooswijck, ll. 24-38, WB VIII, p. 570. In the original: 'De wijsheit is een zelve, 't onderwijzen / In middelen verscheiden. Wijsheit spreeckt / In kercke, schoole, en schouburg: hier ontbreeckt / Geen tong, noch spraeck. zy kan oock zwijgend wercken / In 's menschen hart, en preeckt door stomme mercken: / Want boeckstaef, verf, en print haer' zin beduit, / En beelt voor oogh en brein haer ooghmerck uit. / Zy dreigt, en noodt door straffen, en belooning, / In schilderye of levende vertooning / Van goet en quaet, naer elx verscheiden aert, / Dat dwaelenden te recht brengt en herbaert. / Zoo moet uw jeugt, gelijck een bloem, opluicken, / En 's levens lent tot's burgers heil gebruicken. / Wie vroegh aldus de slangen worgen kan, / Ontwast de schoole, en wort een Staetnut man. 
to mean something else in this context. Evidently, Van den Enden did enough talking. The question is: should he not have remained silent? The point is made explicit in line 9. There wisdom speaks through painting and vertooning: a word indicating a theatrical performance as tableau vivant. This is precisely what Philedonius was not; rather, it was an extended form of responsive monologue.

The end of the poem wraps all this up. Vondel first puns, again-he also started the poem with it - on the name of the young man: 'Vloos' in Vlooswijck resembles the Latin flos: flower. Let this flower flourish, the poet wishes, so that he becomes a true man of state. But almost out of the blue, the beautiful and peaceful image of a budding flower is contrasted with a young man who strangles snakes. 'Let him grow out of this school', the poet adds, so that he becomes a man who can usefully serve the state, or is worthy of it. The reference to Hercules may be clear, who as a child strangled the snakes that had come into his cradle. Equally clear may be the juxtaposition of the young man who has to kill the snakes in order to outgrow the school. In the Christian context snakes can only have one meaning: evil. So, the suggestion is that this school is where evil lurks.

At first sight, the title character of Van den Enden's Philedonius appears to fit in the common Christian narrative frame of a lust-seeker who has to learn the right lesson in order to become a righteous man or, more specifically, a worthy citizen of the state. He has to reject lust. But this Christian reading becomes rather absurd if one knows that only five years later Van den Enden would sketch a society that is ideal because it knows no Christianity and would espouse the abolition of religion, the place of which should be taken by the school. Indeed, in sketching the life and habits of the Indians in North America, the Naturellen ('those who live according to their nature'), Van den Enden indicates that they do not have a religion. Marriage, for instance, is not sacred. Divorce is a heel gewoonelijck, en gebruikelijk dingh ('a very ordinary and common matter'). This is why Christianizing the Indians is despicable, according to Van den Enden. Christians are nothing but pretenders, propagating 'partly opaque, self-made ornamented, and by consequence also often incomprehensible, artificial articles of superstition, or axioms'.333 This hardly sounds like a man who would teach the rejection of well-being, or who would criticize lust for the sake of Christian righteousness.

Moreover, after the Philedonius performance, Van den Enden produced a play by the classical Roman comedy writer Terence, Eunuchus, in 1658. In 
this performance the female characters were played by his female students (including the character who is raped). Although female actors had entered the Amsterdam stage from 1655 onwards, in this case it fitted in with Van den Enden's ideas that boys and girls should be educated together and that female teachers should be implemented. In the eyes of his contemporaries, particularly in the eyes of the Calvinists, such things were controversial. ${ }^{334}$ And not only the orthodox Calvinists were upset by these kinds of ideas and practices. It is said that Spinoza was involved in the production of the Terence play as a student of Van den Enden, and was perhaps even accompanied by him when leaving the theater, when he was attacked by an orthodox Jew. ${ }^{335}$ In this case, the attack was also aimed at someone reputed to be, at the very least, on his way to becoming an atheist: walking evil.

Even if the plays written and produced by Van den Enden did not address controversial issues directly and were performed for a select audience, they clearly took place in a highly charged controversy, which is different from a debate. In this context, the status of school drama is of particular relevance to the architecture in which it took place, or better: the architectonics of its performance. Firstly, two concrete spaces are involved: the space of the school, in the heart of the city at het Singel, and the space of the city theater. Both spaces have their own interiors, but one is distinctly more private. Although publicly accessible, Van den Enden's school was a private school, with private aims and principles in which things were being done. In the privacy of the school the inclusion of female students, for instance, was one such doing. Furthermore, such doings also involved acting. As I have discussed elsewhere, the school drama is a full-blown form of art with considerable revolutionary potential..$^{36}$

The differences from later and especially nineteenth-century forms of bourgeois subjectivity are distinct, here, also in terms of urban architecture. When dealing, for instance, with the forms of display and theatricality in nineteenth-century Paris, Walter Benjamin considered the notions of theater and illusion in relation to world and universe, which were closely connected to the urban environment under Louis Philippe, the 'Citizen King'. Benjamin claimed that for the first time in European history-not just in the period between 1830 and 1848 but also in its aftermath-the 'place of dwelling' began to be opposed to the 'place of work'. The interior of the former allowed the individual to 'sustain him in his illusions' as opposed

334 On this, see P.H. van Moerkerken, Adriaan Koerbagh, p. 12.

335 Steven Nadler, Spinoza: A Life, pp. 110-111.

336 See Korsten, "'But did they not, with it, burn the excrements as well?"'. 
to his dealings with harsh reality in the office. Commercial and social complexities were being kept out of the place of dwelling. Consequently:

From this arise the phantasmagorias of the interior-which for the private man represents the universe. In the interior he brings together the far away and long ago. His living room is a box in the theater of the world. ${ }^{337}$

With this box in 'the theater of the world' the familiar metaphor of the theatrum mundi is alluded to. According to Benjamin, nineteenth-century private man (the bourgeois citizen) lives in his private box, from which he enjoys his internal theater of projections, fantasies, and illusions. The classical meaning of the theatrum mundi metaphor - that the world is nothing but illusion - is revitalized here in a Marxian sense (despite the fact that capitalism had yet to achieve its hegemony). As Benjamin's close friend Adorno explained it, subjects living under the rule of capitalism cannot see the world for what it really is because they are the objects of other forces, as a result of which they are forced to live in untruth.

Having the best and brightest of the Amsterdam bourgeois elite under his guidance, Van den Enden could give them a training as citizens that was radically un-bourgeois in the nineteenth-century sense and in which drama was used to show them the truth. In the privacy of Van den Enden's school, revolutionary ideas were aimed at a distinct brand of disillusionment, by means of which a new kind of world could be explored, discussed and acted out. In this context, I read the performance of Philedonius in the city theater as a highly ambiguous one. It is a play that speaks in different tongues. On the one hand, in the interior space of the school, the inexpressible could be dramatically expressed. On the other hand, in the public space of the theater, the inexpressible had to be expressed in a veiled way, in a secret language that could only be understood by those willing to understand. Those who were not, would either fall into the trap of allegory, understanding Philedonius to be an allegorical play about the Christian soul struggling for salvation and wisdom. Or they would sense that something was 'wrong', but what exactly? Vondel clearly belonged to the latter part of the audience, as did Joachim Oudaen, who would reflect on both Van den Enden's teachings and the play in an extremely critical way. ${ }^{33^{8}}$ Vondel

337 Walter Benjamin, Selected Writings $1935^{-1938, ~ p . ~} 3^{8}$.

338 A poem by Oudaen ends with: 'Wat baat het of men dan gerust en zorgeloos / De losse jeugt zich doet verlustigen een poos, / Met Philedonius zyn rol te laten spelen, / En in hun ziel-verderf 
perhaps even understood the implications of a protagonist who is the 'friend of well-being'. Understanding it, he in part rejected it, although he as well could not really say what he meant.

Public debates related, then, on the one hand, to concrete architectural spaces and institutions in the urban environment: a school or a theater. On the other hand, there was the architectonic of individuals and collectives, of private spaces and public ones, and especially interior spaces that worked differently. The school space of Van den Enden served the public. It was, as I have mentioned, publicly accessible. Yet, it also had a privacy that was unknown to the theater. In the school space, drama helped students to develop their own interior ideas and worldviews. The theater was publicly accessible to all and consequently demanded a shift in privacy. What was publicly shown was to be understood both collectively and privately. So, in terms of architecture in the seventeenth-century Dutch Republic, certain spaces mixed dwelling and working with playing in the sense of play-acting. Moreover, alongside the urban architecture, there was an architectonic at work that shaped the dynamic between individual internal drama and collective imagination, and both in turn were linked to an external world-theater. This dynamic was decisively 'bourgeois', though not in the nineteenth-century sense.

In this context, the classical linkage of theater with illusion was redefined in opposing terms. The rather simple shift of the school drama, from being developed and worked out in school to being performed in the city theater, points to a decisive split in the concept of performance. On the one hand, performance concerns theatricality, where the emphasis lies on theatricality in the public realm, as a 'vision machine'. 339 Some kind of world is made to be shown and seen, and as a consequence can be reflected upon. The dominant questions here are: how can we know this world that appears split between those who perform and who watch, and how is the subjectivity of both involved? On the other hand, performance concerns 'dramatization', where the emphasis lies on enactment. In a performance, something is being done together, playfully and creatively acted out. The major questions here are: what is the world that is being made in play-acting, and what are its consequences for the constitution of the acting subjects?

I will explore the consequences of this split in relation to the world as a theater or as dramatic space, or (as we saw in chapter 5 ) as a scene.

des dootslaaps hen te streelen.' That is: 'What gain is there if, carelessly and in trust / one lets free youth enjoy itself for a while / with letting Philedonius play his part / and to cherish them in the death sleep of their soul's corruption'. Joachim Oudaen, Poezy, vol. 2, p. 222.

339 Maaike Bleeker, 'Being Angela Merkel.' 


\subsection{Dramatization: Theatrum mundi versus mundus dramaticus}

When Friedrich Nietzsche deals with Greek drama in his study on the birth of tragedy, he does so in terms of theatricality. His major concern is how the socio-cultural domain is organized by means of perspective, by orchestrated vision. ${ }^{340}$ Likewise, as we have seen above, Benjamin was concerned with the organization of perspectives and projections in relation to the metaphor of the theater of the world. Indeed, the theatrum mundi metaphor has proven to be such a powerful one because it immediately calls up the idea that we can put the world itself in perspective. The very notion of perspective suggests subjectivity and mastery. There is a point from which things are perspectivized and such perspective, in turn, with the mastery it implies, relates to the distinction between reality and illusion, and by analogy between truth and falsity. This runs counter to a definition of theater offered by Maaike Bleeker who calls it, a 'critical vision machine' that is not 'a matter of spectacle, exaggeration, or make-believe but a matter of becoming aware of how we are implicated within that which we see and how we see it, and how this in turn is implicated in the performance of others addressing us'. ${ }^{341}$ Here the issue of mutual implication is far more important, which comes closer to what I term dramatization.

Although the two are closely related, theatricality is distinctively different here from drama. Drama does not require organization in terms of perspective at all. In fact, drama does not even require a theater audience. The metaphor of the theatrum mundi focused on the audience as the double subject of perspective - namely, as the viewer and as the subject of the the vanishing point..$^{342}$ In contrast, the idea of drama focuses on those who act, are doing something, even if that doing is playing. The difference is hinted at in Van Stipriaan's study on the theatrum mundi metaphor, in which he emphasizes the playful nature or ambiguity of several seventeenth-century plays. Too often, Van Stipriaan states, the Renaissance has been considered 'a thoroughly didactic era, in which play can be the vehicle of morality at best'. In contrast, Van Stipriaan calls the Dutch seventeenth century a

340 On this see Gary Shapiro, Archaeologies of Vision, chapter 4, 'Übersehen: Architecture and Excess in the Theater of Dionysos' and Chapter 5, 'In the Twinkling of an Eye: Zarathustra on the Gaze and the Glance'.

341 Maaike Bleeker, 'Being Angela Merkel.' p. 259. For a broader underpinning of Bleeker's understanding of theatricality, see her Visuality in the Theater.

$342 \mathrm{On}$ the relation between baroque mise-en-scène, perspective, and the production of subjectivity, see Hanneke Grootenboer, The Rhetoric of Perspective. 
'playful-theatrical culture'. ${ }^{343}$ The crux here is that playing is not something to be seen through in search of what is real, but that the interplay of illusions may lead the well-informed to both enjoy the play and to contemplate truth or adequately judge the real state of affairs. Yet, with the latter, Van Stipriaan returns again to the dynamic of illusion and truth as a result of which drama, as the domain of acting-in-playing, is no longer the issue.

The focus on drama, on doing, was crucial to most humanists who wrote school dramas. This holds for Gnapheus, for Macropedius and, more in terms of theory, for Erasmus. In the seventeenth-century baroque, however, the turn toward drama gains a philosophical and novel meaning, as the work of Van den Enden, and later also Spinoza, may show. Both saw illusions as either unfortunate elements of religion, as a lack of knowledge proper, or as the conscious forms of manipulation by those in power. Especially Van den Enden loved theater, but not as a play of illusions. He loved it for what one could do with it by means of drama - that is, by doing, by acting. This had its consequences for the idea of a 'world'. For both Van den Enden and Spinoza the world was not so much a stage upon which people would play their role. Rather, the world was dramatic itself: a mundus dramaticus. This is, at least, what I would like to call it, following Deleuze's ideas on dramatization (see chapter 1 ).

Let me make clear, here, that I am using dramatization in a different sense than, for instance, Allan Nadler in his study on Spinoza. On Spinoza's attitude toward the theater, going back to the time he was attacked leaving the Amsterdam theater, Nadler states:

It's a safe bet that Spinoza never again darkened the door of any theater. Not so much because of any post-traumatic association, but because of his utter disinterest in all things dramatic (the fanatically rationalist Spinoza famously disdained the imagination as the root of all human ignorance and misery). ${ }^{344}$

Nadler is a bit too quick, here, in his handling of Spinoza's ideas on imaginatio, especially in its relation to intellectus. As becomes clear from reading Ethics or Tractatus de emendatione intellectus, for Spinoza, imagination played a crucial role in the build-up of human knowledge. Don Garrett describes this as follows: 
His use of the term 'imagination' is broad enough to include sensation as well as mental imagery and to include modalities of bodily representation that do not represent shape. He goes on to identify imagination as the first and lowest of the three kinds of knowledge or cognition [cognitio], with the intellect (constituted by distinct and adequate ideas) providing the higher (second and third) kinds of knowledge. ${ }^{345}$

So imagination is a category of sensation - and an indispensable one at that-in the path toward true knowledge. It can materialize in the shape of mental imagery, and can capture modalities of bodily representation that do not represent a concrete, recognizable shape 'out there'. In this way, imagination escapes the logic of representation. Because of its bodily locus in terms of sensibility, because of its bodily activity, and because it falls outside the realm of representation proper, I read Spinoza's use of the concept in light of what I call dramatization. Imagination, in this context, is not something one has, but something one enacts.

In one of his more enigmatic texts Gilles Deleuze asks what kind of agency is involved in the method of dramatization..$^{346}$ The text was a lecture before an audience of colleagues and their questions testify to the text's enigmatic character, perhaps because Deleuze himself uses both the notions of theater and drama. The enigma may also be the result of a principal shift. Taking Plato's idea as his starting point, Deleuze at first seems to start from the realm (and the logic) of representation, as when an idea is represented in the real world. With hindsight one must conclude that he in fact starts with Plato because, essentially, the latter's conceptualization of ideas does not fit a logic of representation at all. With Plato one jumps from something that cannot be present as idea to a form of actualization that borders on it. The impossibility of its presence does not mean that the idea is not real, however. It is real, but not yet actualized, to use a Deleuzian term.

This is why, in analogy, Deleuze can make the move to his distinction between the virtual and the actual. Both are real, but they differ in terms of epistemology and ontology. The way in which the virtual becomes actualized, by some form of agency or dynamism, is what Deleuze calls 'dramatization'. How does this work? This is Deleuze speaking:

345 Don Garrett, 'Representation and consciousness in Spinoza's naturalistic theory of the imagination'.

346 Deleuze, 'The method of dramatization'. In it, Deleuze explains in brief what his study into repetition and difference amounted to. For a short introduction to the concept, see Stephen Zepke, 'Becoming a Citizen of the World'. 
Dynamisms, and their concomitants, work beneath all the qualified forms and extensions of representation, and constitute, rather than an outline, a set of abstract lines coming out of an unexpected and informal depth. A strange theater made of pure determinations, activating space and time, acting directly on the soul, having larvae as actors-and for which Artaud chose the word 'cruelty'. These abstract lines form a drama which corresponds to such a concept, and which directs both its specification and division. Scientific knowledge, but also the dream, and also things in themselves, dramatise.

To be clear, there is no stage, here, by means of which something is represented. It is a dynamism itself: a drama evolving between agents and forces which effectively leads to the actualization of something. Crucially, Deleuze is concerned with a theater of non-representation, and in the questions that follow the lecture it becomes evident how much confusion this concept provokes. For all participants in the discussion it seems to be self-evident that dramatization must fit in a theatrical, perhaps even tragic, and in any case representational paradigm. Without saying this in any explicit terms, however, Deleuze is predominantly concerned with the question of how to define what might be the new in an immanent world, which is also why he is interested in 'the dark precursor', the invisible path that is already being made before lightning strikes.

In the change from virtual to actual something new is produced. We can know what is new because, paradoxically, it represents something that does not fall under the rubric of representation (yet). This is also why we cannot consciously act toward it, for then we would already know it; it would be possible, as Deleuze would argue. In contrast, it is through play-acting that we can stumble across the new, or can produce it unexpectedly.

Just as theatricality is related to theater but not restricted to the domain of theater, so dramatization is related to drama but not restricted to its domain. Van den Enden's text Free Political Propositions and Considerations of State proves as much. In the preamble to this text Van den Enden admits that he would never have thought of writing something about this topic, had he not been asked to act as a mediator for a group of Dutch citizens who, tellingly, wanted to start a new life elsewhere. What this new life would be, and how it could be defined, was not that clear at all when they asked Van den Enden for help. They started to play/act together, every party taking its part. It was in this play/acting together that Van den Enden found something new. As he expresses it himself: 
Up until the year 1661, I had never had the least thought to ever let any letter in writing about political matters appear in the light of day, had it not been that, as unexpectedly as un-thought of, a possibility appeared to me to ask, for a small number of people in need, for an expedition to New Netherlands with the thereto appointed Chamber of Colonies in this city. ${ }^{347}$

Whether Van den Enden was asked to act as a mediator, or whether he proposed to take on this role himself, he started from the position of the 'un-thought' — started to act, entering a discussion that radically surpassed the simple case concerned. In taking this role, Van den Enden, in both describing and imagining a new world, would stumble into the 'new' which would lead him to sketch the world anew.

Regarding such description, my argument can be related here to a study which was controversial at the time of its publication: Svetlana Alpers' The art of describing: Dutch art in the seventeenth century (1983). As may have become clear in my consideration of Frans Hals' work (see chapter 4), I agree with Alpers that the scholarly treatment of baroque art has been suffering from what are ultimately too emblematic or moralistic interpretations. Baroque art was, indeed, also intrinsically descriptive. Yet, as the case of Van den Enden may prove, the Dutch Republican baroque attitude was not so much a matter of description, but helped to actualize worlds in a more general dynamic in which it took part. The Republic and Amsterdam did not just find their place in an already established world, but actualized a world, a new world scene in which the New World on the other side of the Atlantic found itself together with the 'old' one.

By using the verb 'actualize', I take my cue from a kindred pair of distinctions made by Hannah Arendt and Gilles Deleuze, respectively, between two modes of 'making'. Following Arendt's distinction between acting and making in The Human Condition, the Republic and Amsterdam were not making history, as if it could be made like a house, according to a plan. Instead, due to their own political, economic, aesthetic, and often dramatic actions and acting, the Republic and Amsterdam did not just stumble into an already existing world but actualized one-politically, juridically, and aesthetically. As for Deleuze, his problem was how to explain the 'new' in a

347 Van den Enden, Vrije politijke stellingen, p. 125. In the original: 'Voor het laest van 't jaer 1661. had ik noch gheen de minste ghedachte, van oyt eenige de minste letter schrifts over politijke zaken in 't licht, of aen den dach te geeven, tot dat my, zo onverwachts, als onverdachts gelegenheit, om voor zeekere weinige en verleegen lieden eenigh waerdig expedient na NieuwNeederlandt aen dezestats ghewezen Colonies-kamer te verzoeken, voorquam.' 
Spinozist, radically immanent world. In order to solve this, he distinguished between the virtual and the actual, with the virtual not being not-real, but real and not-yet-actualized. To him, dramatic action would bring in difference and the new. ${ }^{348}$

This is why the theatrum mundi metaphor may no longer be apt to describe what happened in the seventeenth-century Dutch Republic. Here, the world was no longer a stage that one could look at from the perspective of the real or the Real. Instead, the world itself was dramatized by play-acting with and in the real, and thus it turned into a mundus dramaticus. The one did not replace the other. Just as classicism and the baroque existed next to one another (with the baroque emerging victorious from their entanglement) so did the two metaphors. This coexistence or coincidence can be traced in a famous work by Constantijn Huygens (1596-1687), secretary to stadholders Frederick Henry and William II, diplomat, composer, musician, architect, gardener, and writer.

\subsection{Fluid borders between theatricality and dramatization: Huygens' 'Sunday'}

Constantijn Huygens' lengthy poem Oogentroost (literally: Eyes-comfort) took the blindness of one of his best friends as a theme. Regarding this theme, his poem did not present a coherent and consistently developed image since the poem was connected to a complicated intertextual web. ${ }^{349}$ Regarding that web, a simple look at the Bible Concordant will suffice, as Jürgen Pieters argued, to see how blindness can be read in opposite ways. On the one hand, it is a matter of sin: the blind will not and cannot see. On the other hand, blindness may indicate deep and superior insight, because the blind can spiritually see what those who are blinded by reality cannot..$^{35^{\circ}}$ It is here that blindness corresponds with allegory. It connotes seeing differently. As may be have become clear in chapter 6, I am more interested in the literal, as it connotes baroque materiality or texture. ${ }^{35^{1}}$ In

348 For a both fruitful and insightful dealing with the Dutch baroque in terms of Deleuze's dramatization, see Marrigje Paijmans, Dichter bij de waarheid.

349 This intertextual web in Huygens' Oogentroost was the object of research for a group of scholars led by Jürgen Pieters. On the project see: http://www.nederlandseliteratuur.ugent.be/ onderzoek/Ooghentroost

350 My translation. See Jürgen Pieters, 'In denkbeeldige tegenwoordigheid'.

$35^{1}$ In a recent debate on the responses to Coetzee's novel Disgrace the distinction between the literal and the figural appeared to be pivotal. In J.M. Coetzee and the Ethics of Reading, Derek 
this context, a third form of blindness emerges: that of the dream in which our eyes do not see, but images present themselves nevertheless.

Such a dreamlike situation is evident in a famous poem by Constantijn Huygens, taken from Heilighe Daghen (Holy Days, 1645), entitled Sunday:

Is it Sabbath, my Soul, or Sunday? None of the two.

The Sabbath is gone with its obligations:

And the sun that I see, shone yesterday as it does today.

But the one I do not see does not shine as it seems.

Sun, that I do not see but through my sins,

Son of God, who on this day comes to tread on earth,

Proud as a Bridegroom entering the main road,

I see a Sunday without end, through your Wounds.

So if it is Sunday now as well, one may call it God's Sonday,

Yes, and God's Sootheday too. But let me curse us,

For whichever of the three I turn to I find us in guilt.

God Sun, God Son, God Soothe, how long does your patience last?

How long will you suffer, Lord, your Sonday, Sootheday, Sunday,

Ungraciously being spilled, spoiled, misspelled in Sinday? ${ }^{352}$

Luckily enough, the English words sun, son, and sin allow for a translation of Huygens' experiment with language. I had more trouble finding an

Attridge strongly defended a mode of literal reading, since most responses to Disgrace were, so he argues, allegorical. It was as if everything particular that happened in the novel was to be read as a reflection on the more general or deeper state of affairs in South Africa. This allegorical obsession framed the potential of the novel by a presupposed 'other' meaning. We should strive, so Attridge argued, to read things more at face value in order to sense what the novel is actually doing. In his response to this analysis Ernst van Alphen goes a long way in following Attridge but in the end points rightly to the dichotomy that Attridge uses to make his point (see van Alphen, 'Affective Operations of Art and Literature'). There is no language without meaning, and even literal meaning is, indeed, meaning.

352 In the original: 'Is 't Sabbath dag, mijn Ziel, of Sondagh? geen van tween. / De Sabbath is voorbij met sijne dienstbaerheden: / En de sonn die ick sie scheen gisteren als heden. / Maer die ick niet en sie en schijnt niet soo se scheen. / Son, die ick niet en sie als door mijn' sonden heen, / Soon Gods, die desen dagh het aerdrijck weer betreedden, / Fier als een Bruijdegom ter loop-baen ingereden, / 'Ksie Sondagh sonder end, door dijne Wonden heen. / 'tZij dan oock Sondagh nu, men magh't Gods Soon-dagh noemen, / Ia, en Gods Soen-dagh toe. Maer laet ick ons verdoemen, / Waer ick van drijen gae ick vind ons inde Schuld. / God Son, God Soon, God Soen, hoe langh duert dijn geduld? / Hoe langhe lijdt ghij, Heer, dijn' Soondagh, Soendagh, Sondagh, / Ondanckbaerlick verspilt, verspeelt, verspelt in Sond-dagh'. For the text, see: http://www.let. leidenuniv.nl/Dutch/Huygens/HeiligeDagen.html. For another translation by P.J. Large see: http://www.hull.ac.uk/php/abspjl/Dutch/Huygens/Willig.html 
equivalent for the word zoen, from verzoenen, indicating Redemption day, but meaning, literally, to reconcile. I translated it as soothe, which connotes the archaic sooth (truth or fact), and which means 'soften' or 'mitigate'. Accordingly, the four versions of Huygens's day correspond in English with sunday, sonday, sinday, and sootheday.

The most common reading of or response to this poem has been an allegorical one, aimed at defining the poem's real or ultimate meaning, as is illustrated, for instance, by the website of the Royal Library. ${ }^{353}$ Indeed, the poem itself almost enforces this allegorical route. Much like in Huygens' Oogentroost, a visual dynamic is installed in line 3 with the 'I see'. This seeing is defined first empirically or realistically. The sun that the 'I' could see yesterday is the same as the sun that he can see today. But after that, almost naturally, the allegorical reading is provoked by line 4, where sight is blocked, or where an appeal is made to that which one cannot see.

Now, the allegorical impulse is about defining what lies beyond what 'seems' to be the case. Note, however, that in this case the 'I' need not see behind, but through the clouds of his sins, like he must later see in and through the wounds of Jesus. This 'through' opens up a rather different meaning and a different way of relating to the world, for it replaces space with texture. In my reading, Huygens' poem is an exploration of closeness, of a direct confrontation that is not an issue of everyday affairs but a dramatic one, involving all the senses in a situation in which something is acted out.

Heightened awareness is installed with the very first line, where the ' $\mathrm{I}$ ' wonders what this Sunday is. The world of everyday reality, with its own historical pathways and parties, has not disappeared but is intensified in relation to the ontological issue of something that is happening, here and now. On the face of it, the sun shines today as it did yesterday. Yet, there is a shift in texture, from line 5 onward. It is not behind his sins that the 'I' has to see, as if there is a truer reality behind things. The sun shines through the sins of the 'I' and in this shining through an actor appears: Jesus, turning sun into son, and turning the situation into a here-and-now, 'on this day'. The intensity or heightened awareness of what is happening shifts the time-scale in relation to the question of how what is happening will result in something and come to mean something. Time is intensified, binding

353 See: http://www.kb.nl/dichters/huygens/huygens-o6.html. See also FrankJ. Warnke, 'Sacred Play: Baroque Poetic Play'. For a less allegorical, and more contextual interpretation, see the introduction by L. Strengholt in Constantijn Huygens, Heilighe daghen, or Rita Verbrugge, 'Huygens' Pilgrimage Through the Calendar Year'. 
moment and eternity, turning the moment into something 'without end', which is emphasized in the following line by the concentration of the 'now'. The dramatic nature of the situation is highlighted in line 11, where the 'I' turns to the three possibilities, one by one, and where he is implicated by the three, through which 'I find us in guilt'.

At the same time there is a fluid transition here from the dramatic situation to a theatrical one. Moving forward, the lyrical ' $I$ ' leaves the realm of heightened awareness, for he starts to wonder how long this situation of triple misuse will last. With this conclusion the drama of the situation is lifted and we enter a theatrical framing. We are no longer implicated in what we see, but look at something from a reflexive distance. The eye has left the telescope, the dream is lifted, the dramatic situation is now framed theatrically. This is captured in line 12 with an address to God which, at the same time, introduces the theatrical actors that are lyrically invoked: 'God Sun, God Son, God Soothe'.

Earlier, I quoted Maaike Bleeker's definition of the theatrical as 'a matter of becoming aware of how we are implicated within that what we see and how we see it'. ${ }^{354}$ The key term here is 'implicated', or, to put it in material terms, 'entangled in', 'woven into'. Theatricality and dramatization differ in that the former entails a distribution between those who act and those who view, under a visually dominant frame that defines and splits a space. The latter indicates something being acted out on some sort of podium on which all actors are involved, sensually linked in a situation that defines the texture of time and history. On such a podium, the moment of attention is a moment when looking, seeing, and sensing position human subjects as dramatically implicated in a world the texture of which they can feel, in an intensified awareness, both intensifying time and expanding it, without knowing as yet what it all means or what it will lead to. That moment comes to be fluidly interwoven with a theatrical moment of reflection, where problems of the past are related to problems of the future, in a temporality that is cut up into past, present, and future, and that is measured in lengths, as when the lyrical 'I' asks: 'How long' to go? As such, Constantijn Huygens' Sunday is exemplary of the mutual implication of theatrum mundi and mundus dramaticus.

In this case, the entanglement of the two metaphors gave rise to a dreamlike situation. In the next and final chapter I will be focusing on principal differences between the two in terms of their potentials to produce or safeguard a distinct world, with a distinct organization. 
This content downloaded from 132.229.156.144 on Tue, 05 Feb 2019 10:43:02 UTC All use subject to https://about.jstor.org/terms 


\section{Public theater, collective drama and the new - Van den Enden and Huygens}

\subsection{Theatrum mundi, public acting and the plane of collective imagination}

The conflict between the two dominant political parties in the Dutch Republic, orangists and republicans, was not just a political conflict within one and the same world. The two implied different worlds, different attitudes, and a different baroque. The same, of course, holds for the conflict between Protestants and Catholics, or between those who believed in God and those who flatly denied his existence. One of the figures in which all these tensions appeared to come together was Franciscus van den Enden (1602-1674), a remarkable figure in his own right as well as the teacher of Spinoza. The website about his person and work introduces him as: 'Former Jesuit, neo-Latin poet, physician, art dealer, philosopher, teacher of Spinoza, and conspirator against Louis XIV', ${ }^{314}$ It could have added: 'book-seller, founder of a revolutionary Latin School, playwright, stage-director, freethinker'. Although Van den Enden was clearly an energetic man, Louis XIV proved a bigger fish to fry. Towards the end of his life, his freedom of speech had become more and more restricted in the Dutch Republic, and Van den Enden travelled to Paris in 1671 to open up a Latin School again, just as he had done previously in Amsterdam. Here as well he would preach revolution, advocating a free democratic republic. He would also take part in the Rohan complot that aimed to remove king Louis. These conspirators were found out and, whereas the aristocratic ones were honorably beheaded, citizen Van den Enden was dishonorably hanged on 27 November 1674.

Van den Enden's ideas about the non-existence of God implied a radically new form of thinking about how human beings appeared to an Other, to others and to themselves. For centuries the theatrum mundi metaphor had been the dominant metaphor that defined how people thought of their appearance in the world, their appearance within the all-encompassing view of a supreme being. ${ }^{315}$ That metaphor came to lose its ground however,

314 The website is designed, developed, and maintained by Frank Mertens; see: http://users. telenet.be/fvde/index.htm?Home1, accessed 3 February 2017.

315 For the long history of this metaphor see Lynda G. Christian, Theatrum mundi; for its relation to the history of early modern theatre, see the work of, for instance, Erika Fischer-Lichte, History 
and three of Van den Enden's texts show as much. Two of them dealt with the New World, and the third was a school drama: Philedonius. All three demonstrate how Van den Enden was not so much concerned with human beings as the players on an earthly stage. He was more concerned with the pedagogical potential of drama in the private space of a public school, where worlds were to be found and explored anew. This exploration found its extrapolation in the real world of practical action.

With the Stoics, in classical Rome, the metaphor functioned to support stability. The turbulence of the world was just appearance to the man who was able to remain stable; his role in life was only one staged by other, divine forces. This classical conception changed in the Middle Ages. In light of the Catholic worldview, the metaphor came to indicate the second-hand, illusionary nature of earthly life as opposed to the real life of the heavenly hereafter. By extension, the earthly business of human actions was chimerical as opposed to the truth of the vita contemplativa. Human affairs were considered from the viewpoint of God, then, and this meaning of the metaphor lived on until the seventeenth century. ${ }^{316}$ But in the course of that century another meaning became increasingly important, which was that man staged himself socially or politicaly, before his fellow men. This meaning sprung from a growing consciousness of the fact that human beings had roles, and played them, in a world that was socio-culturally organized (a major point in Richard Sennett's The Fall of Public Man). Here it was not so much illusion as deception that characterized the dynamic; theatricality was equated with fraud and deceit.

In its historical context, Lynda Christian considers the theatrum mundi metaphor to have two different modes. There was the 'Stoic-NeoplatonicChristian' mode, where some form of divine logos framed a meaningful pattern within which human life would be staged and would have to be played out. Then, there was the satiric or Lucianic mode, with its more cynical view that life was folly and man 'the greatest fool of all' ${ }^{3{ }^{17}} \mathrm{~A}$ third mode, hinted at by René van Stipriaan, might be described as rhetoricophilosophical, where rulers used theatrical deceit in order to make the body politic work (in the final chapter 8 we will come back to this when dealing with a painting entitled The triumph of Folly: Brutus in the figure of

of European Drama and Theatre.

316 On this see Erika Fischer-Lichte, 'Theatrum vitae humanae.' History of European Drama and Theatre, pp. 50-144.

317 Lynda G. Christian, Theatrum mundi: The history of an idea, pp. 6o-61. 
a fool before king Tarquinius). ${ }^{318}$ This mode was propagated by figures such as Machiavelli and his Christian counterpart, Diego de Saavedra Fajardo. Theatrical deceit was used here in the service of a political order, to make people aware and make them judge. Especially in the context of the latter, this was why theater became less a vehicle of illusion and more an enlightening instrument, that could teach people how not to be deceived, or that could unveil how things really were. This mode would, at least in part, be pertinent to the establishment of the Amsterdam art society Nil volentibus arduum, founded in 1669 . In it, former pupils of Van den Enden and some others joined in an attempt to mobilize theater in a battle against superstition and illusion.

The public status of Van den Enden can be traced in his pupils and in what they did, but also in what others reported on him. For instance, while in the Netherlands the Danish scientist, scholar, and poet Ole Borch (or Olaus Borrichius), kept a diary. ${ }^{319}$ Around 3 and 4 April 1662 he wrote that a certain Joannes Alexandri had told him that:

...there are atheists here, predominantly Cartesians, such as Van den Enden, Glasemaker etc., who in turn teach others and although they do not proclaim atheism, since they often speak of god, they nevertheless understand God to be nothing else than the entire universe... ${ }^{320}$

This passage hints at the debates in the Republic around atheism or the nonexistence of God, with Descartes as the explicit common denominator and Spinoza as the elephant in the room. It was perhaps the most controversial and most feared topic of its time. It was also an issue of controversy and concern because radical thinkers appeared to teach, perhaps not a public activity in itself but one of great public interest and impact. This provokes the question of the precise nature of Van den Enden's public appearance and

318 On this, see René van Stipriaan, Leugens en vermaak, especially Part III, 'Ethos and Epistèmè' (pp. 157-230).

319 On this, see Olaus Borch, Itinerarium 1660-1665, vol. 2, p. 92. The quote can also be found on a site dedicated to Van den Enden, made by Frank Mertens of Ghent University, see Frank Mertens, ed., Online documents regarding Franciscus van den Enden. See also the 'Inleiding' (introduction) by Wim Klever to Franciscus van den Enden, Vrije Politijke Stellingen, especially pp. 27-28. On the broader context of the relations between Van den Enden, Spinoza, and Borch, see Eric Jorink, 'Outside God there is nothing'. Van den Enden is also an important figure in Israel's Radical Enlightenment.

320 In the original: 'Esse hîc atheos, eosqve potissimum Cartesianos, ut van der Enden, Glasemaker etc: qvi et alios subinde edoceant, non qvidem profiteri eos Atheismum, loqvi crebrò de deo, sed per Deum nil aliud intelligere qvam totum hoc universum...' 
performance. Did he stage himself? Could his acts be understood in terms of one of the modes of the theatrum mundi metaphor, especially the third rhetoric-political one? Or should we consider them rather in dramatic terms?

Reflecting on the Early Modern societies in Europe, Arjan van Dixhoorn calls such societies theatrical because they were full of theatrical events. He defines them as follows:

This means that a situation becomes theatrical as soon as an audience perceives an act as intentional and recognizes the accentuated movements and speech as interactions between performers and spectators. In sum: events oriented towards public show and recognized as such are theatrical events. ${ }^{31}$

Here, Van Dixhoorn follows a study by Walter Prevenier and Wim Blockmans, who in turn derive their ideas on a 'theater state' from the work of anthropologist Clifford Geertz..$^{32}$ Yet, when Geertz's idea of theatricality in nineteenth-century Bali is taken up and applied to Western societies from Early Modern times, there is not only the risk of equating exotic and so-called primitive societies with early Western societies, there is also the risk of ignoring intrinsic and specific relations between power and theatrical display.

In the discussion around the theatrical status of Early Modern society one almost inevitably encounters the interchangeable use of notions such as theater and spectacle, ritual and show, display and performance, ceremony and farce, a mass in church and a performer singing a song in the public square, a coronation and a court of law, an execution and the public performance of a tableau vivant. All these different forms of public events fall, as Van Dixhoorn argues, under the umbrella of the 'theatrical'. To be sure, all these public acts have theatrical aspects, and they all imply forms of performance. But then again, what made one event theatrical instead of ritual, theatrical instead of spectacular, or more theatrical than ceremonial? And what was the relation of theatricality to power? Calling Early Modern states theatrical is definitely to the point, but it is important to define the specific kind of theatricality at stake in these states, as opposed to in, for instance, the classical Greek city state, nineteenth-century

321 Arjan van Dixhoorn, 'Theater Society in the Low Countries'.

322 Clifford Geertz's Negara: The Theater State in 19th Century Bali was published in 1980. The study by Blockmans and Prevenier was entitled The Burgundian Netherlands. On its influence, see for instance Graeme Small in his 'Introduction to the 2002 edition' of Richard Vaughan's Philip the Good, pp. xix-li, esp. p. xliii. For an important early survey of studies into the early modern theater state, see also Peter Arnade, Realms of Ritual. 
Bali, or seventeenth-century Dutch society. In Geertz's pre-colonial and non-Western nineteenth-century Bali, for example, the aim of power was to serve the realization of ceremony and ritual, in contrast to classical Greek city states where theatricality was central to both the anthropological and political organization of society.

John J. McGavin's idea of a 'dramaturgical society' — from his study on texts by late medieval and Early Modern Scottish chroniclers-is noteworthy in this context. By defining late medieval or Early Modern society as dramaturgical, McGavin highlights how people were constantly preoccupied with how their actions would read as a performance or, rather, as being scripted. McGavin consequently distinguishes 'dramaturgical' from 'theatrical', with the latter emphasizing the role of the visual and of the public. The first emphasizes the dual positioning of people as both performers thinking about how to perform things and audience members looking at something in the sense of looking for something: they were consciously and self-consciously 'reading' what was being performed..$^{23}$ If we take this to apply to Van den Enden we need to note first that relatively few people had actually met him or his former pupil, Spinoza. There were few who had actually heard them speak or had even read themselves what the two had expressed in writing or in print. Make no mistake though: Van den Enden and Spinoza were both very much concerned with how they appeared and, in this sense, fit the dramaturgical model of McGavin much better than Van Dixhoorn's theatrical one. Interestingly, although he was very much concerned with how he appeared and how he was read, Spinoza was not that active as a public figure. On the contrary, he shunned the public. Considering how dangerous his writings were, his preferring a situation of anonymity may have been justified. Yet, he was very much alive in the public imagination. Could this collective imagination, then, be the 'space' in which — or the plane on which-Spinoza's performance would take place?

It was the disturbance of collective imagination that had brought authorities to act against Van den Enden in 1665, when he published Free Political Propositions and Considerations of State..$^{32}$ This controversial text was conceptualized between 1661 and 1662, when Van den Enden was acting as the mediator between a group of Dutch citizens who wanted to emigrate

323 McGavin falls back especially on an article by Peter E.S. Freund, 'Social Performances and their Discontents', in the broader context of performance theory as developed by Erving Goffman and Richard Schechner. John McGavin, Theatricality and Narrative in Medieval and Early Modern Scotland, pp. 15-16.

324 In the original: Vrije Politijke Stellingen, en Consideratien van Staat, published in English as Free Political Propositions and Considerations of State in the translation by Wim Klever. 
to the New Netherlands and the administrators of the Chamber of Colonies in Amsterdam who had to give their permission. ${ }^{25}$ The New Netherlands were located in Northern America, on the South River (currently Delaware), and Van den Enden, being their mediator, had written a short treatise on the region. In it he not only described the land and its inhabitants but also expressed his vision of a new kind of society there. The text was printed in 1662 as part of a collection of documents under the title Brief Account of New Netherlands' Situation, a collection that was the result of Van den Enden's acting as the spokesman for the group of Dutch citizens. ${ }^{326}$ As such, he had written several requests and proposals that he had defended in conferentien (meetings) with the members of the Chamber. The latter were greatly troubled by the sketch Van den Enden gave of this new society. It would consist of individual free men who had the right to bear arms so as to be able to defend their freedom. They would govern themselves democratically by means of mutual consultation in a society that knew no organized form of religion. This would require free speech in the most principal and radical way. In this context, one of the most controversial points was surely the prohibition of all priests, preachers, vicars, etc.. They were excluded because they could not live with the idea of radical free speech and would only cause unrest, according to Van den Enden.

The Amsterdam authorities, having learned about all this, were not amused and would not allow it. This is what brought Van den Enden to add yet another text to the growing collection: an allegory entitled Na-Reeden ('Afterword') in which he espoused a radically new form of state organization. Having had enough of his insistent requests and being troubled, especially, by this last explicit form of criticism, the authorities gave Van den Enden a disputatieverbod in 1662: he was no longer allowed to speak publicly about the issue, most likely due to the atheistic nature of the new society and new world he had sketched. ${ }^{327}$ Despite this prohibition, Van den Enden decided to work out his vision systematically in the following years. He wrote a work that consisted of three parts: the first part was the already mentioned Free Political Propositions and Considerations of State, the second part dealt with the true interests of the Dutch and how these should be served politically, and the third part dealt with the construction of the Republic as a confederation of cities..$^{23}$

325 On all this see the 'Inleiding' by Klever to Van den Enden's Vrije politijke stellingen.

326 The original text of Kort Verhaelvan Nieuw Nederlands Gelegenheit can be found here: http:// www.wdl.org/static/c/4065/service/4065.pdf. For an English translation, see Van den Enden, Free Political Propositions and Considerations of State (1665).

327 The source on this prohibition to speak is again Borch, Itinerarium 1660-1665, vol. 2, p. 92. 328 Van den Enden, Vrije politijke stellingen, pp. 129-130. 
The majority of these texts were not published. Yet this did not mean the content of the manuscripts was unknown. The previously mentioned Borch also wrote about how he had heard that 'Van den Enden has handed certain manuscripts intricate with the secrecies of his philosophies to certain friends .... ${ }^{329}$ Via what Borch had heard, Van den Enden 'comes to life' as a person and as a body of work, and as a result a conversation or debate was fueled again. Moreover, Van den Enden is not described here because of how he performed, but because of what he did. This suggests the public debate was not that public at all, but took place via circles or chains of friends and acquaintances who would tell one another what was going on. The paradox of course is that 'what was going on' was people talking about what was going on. This was obviously much more than mere talk, or language. The actors concerned came to life, dramatically, because of what they had done. Thus, they did not appear so much as actors on a stage but as imaginary yet real figures acting dramatically. In light of all this, the diary of Borch testifies to a specific kind of collective plane that was also individual, both private and public, fueled by talking in private spaces, or in any spaces where people might read, hear, and discuss things. Van den Enden became an actor in Borch's head (and diary), together with others who participated in the debate on atheism. That is to say: when Van den Enden was prohibited from speaking in public on the issue of atheism, the debate stopped as a public performance but was continued dramatically. In a sense, the prohibition may well have intensified it on this plane of collective imagination.

Partly, then, Amsterdam was an example of Early Modern theatricality in the churches, in the squares and streets connecting the urban interior with the contact zone of the harbor. At the same time it allowed new forms of public meeting and theatricality to come into being such as in the new theater, the new city hall, the new bourse. There was also an architectonics of an internalized yet collective plane, however. Here, some form of dramatization was at stake, in the sense that actors did not appear on some sort of stage. Rather they took part in dramatic actions on the plane of collective imagination.

Still, Van den Enden also acted on the newly established public stage of the Amsterdam theater. He produced and wrote school dramas that were eventually performed there; dramatically acted out first in the privacy of the school, they were then made public and staged in the theater.

329 Olaus Borch, Itinerarium $1660-1665$, vol 2, p. 92. In the original: 'Van den Enden qvædam philosophiæ suæ arcaniora communicâsse qvibusdam amicis manuscripta...' See also: http:// users.telenet.be/fvde/SourcesP/Borch_04_1662.pdf 


\subsection{Speaking for those who understand: a school drama in a theater}

The school dramas produced and written by Franciscus van den Enden are of interest because they functioned in different architectural spaces. As instruments in Van den Enden's pedagogical endeavor at his Latin School, the plays functioned in a space connected to both teachers and pupils. In several instances, however, they moved into the public urban space, and more specifically into the Amsterdam city theater. Philedonius, for instance, a play in Latin, was performed twice in the city theater in 1657 , probably for a select audience. ${ }^{33^{\circ}}$

The play is influenced by the medieval genre of the esbattement, which in turn was inspired by the tradition, by scholastic or dialectical reasoning. It is organized into three acts. These are not subdivided into scenes, however, but in 'Uitkomste' ('Results' or 'Conclusions'). In the three acts there are respectively eight, four, and nine of these 'conclusions', which are the result of argumentative encounters or internal considerations. Philedonius starts out by stating that his luck or well-being exceeds that of kings or heroes, is higher than the power of fortune, and makes him god-like. He goes on to encounter a series of characters who either try to teach him otherwise or tempt him to persist. First of all, there is Prudence, who would like to teach Philedonius that there is only one God whom one should fear. Yet Prudence is countered by Abundance, Honor, and later even Lust, who would like to teach Philedonius how to enjoy life. In the end Mercy brings him back to the lap of the Christian worldview, with a final argument between Body and Spirit. All these final considerations take place, tellingly, in Philedonius' dreams. These have taught him a final truth, as a result of which he can come to a final conclusion, which is that he repents his former ways and promises to lead a better life.

There is a praise poem by Vondel on the leading actor in Philedonius. ${ }^{3{ }^{31}}$ The subtitle of Vondel's praise poem indicates that it concerns the performance

330 Fairly little has been written on Philedonius. For an overview, see Mertens, ed., Online documents regarding Franciscus van den Enden. It is surprising that scholars so far have not been looking at the relation with Lucretius' De rerum natura.

331 The title of the poem is: 'Tooneelkrans voor den E. Jongelingk Nikolaes van Vlooswyck, toen hij de rol van Filedonius of Lusthart, bij Dr. Franciscus van den Enden op 's Wijzemans spreuck door zijne Latijnisten ten tooneele gevoert, zoo loflijck en stichtig uitbeelde' ('Theatre-crown for the honorable young man Nicolas of Vlooswyck, when he depicted so praiseworthy and didactically the role of Philedonius or Lust-heart, put on stage by dr. Franciscus van den Enden's Latin students according to Wiseman's aphorism'). Vondel, WB, VIII, pp. 570-71; http://www. dbnl.org/tekst/vondoo1deweo8_01/vondoo1deweo8_01_0181.php\#182. On the relation between Van den Enden and Vondel, see J.F.M. Sterck, Hoofdstukken over Vondel en zijn kring, pp. 65-67. 
by the young Nicolaes van Vlooswijck. Considering that the young actor was one of the sons of burgomaster Cornelis van Vlooswijck and his wife Anna van Hoorn, Vondel may well have been praising the son not so much for the content of his role but because of his status and future function in society. Perhaps he also knew all too well how his fortunes could depend on a burgomaster's family support (he would be supported by Anna van Hoorn financially, and would dedicate his play Jephta to her in 1659). The title of the play itself is translated by Vondel as 'Lusthart'. This may be derived from the short Dutch introduction provided for the general audience by Van den Enden himself. Yet, strictly speaking, Philedonius means 'the friend of hèdonè'. Since Van den Enden described himself — next to being the leader of the Latin school—as a philosopher, he would have been familiar with the meaning of philo, just as he must have been familiar with the work of Epicurus. Moreover, the resemblance between Philedonius and Philodemus is close and perhaps not coincidental. Philodemus of Gadara (c. 110-40 BCE) was a somewhat obscure Epicurist philosopher and poet whose writings, in the form of epigrams, were known via the Anthologia Graeca (some of his work would be recovered in the eighteenth century). The epigrams were all love poems or erotic ones.

Given this almost explicit yet hidden Epicurean context, it is telling that the major aim of Van den Enden's ideal state sketched a decade later, in between 1662 and 1665 , was that it took care of the people's 'well-being'. This was, indeed, the meaning of hèdonè before it was deformed into 'lust' by the Christian tradition, within which the work of Epicurus was despised. So, Philedonius would be the 'friend of well-being' for the well-informed, and for the even better informed might be a reference to Philodemus. For the more orthodox Christian it would mean 'he whose heart tends toward lust', which is the equivalent of 'Lusthart'.

With respect to both the social status of the burgomaster's son and the content of the play, and by implication Van den Enden and his school, Vondel's poem ends ambiguously:

Wisdom is one and the same, teaching In means disparate/diverse. Wisdom speaks

In church, school and theater: here lacks,

Neither tongue, nor speech. She can also work silently

In man's heart, and preach by mute signs:

Because letter, paint, and print indicate her sense, And depict her aim for intellect and eye.

She threatens and invites by punishment and reward, In painting or live tableau vivant 
Of good and evil, each to its disparate nature,

Which straightens those that are wandering, giving new birth.

Likewise your youth should unfold, like a flower,

And use life's spring to the welfare of the citizens.

One who can smother snakes so early,

Will outgrow the school, and become a worthy state-man. ${ }^{32}$

Vondel moves with care, that much is clear. Nicolaes van Vlooswijck was not the only burgomaster's child at Van den Enden's school; several sons and daughters of the Amsterdam elite were enrolled. So if there are unfriendly details in Vondel's text they should not be too explicit. In line 1, Vondel begins by saying that wisdom is 'one'. This accords with the idea that Christian wisdom is 'one' (although of course this was the cause of fundamental debates). Vondel then adds: 'teaching is diverse in means'. This may point to the fact that wisdom can be expressed and taught by different means: in church, school, theater, or by literature, painting, etc. Yet, the words are too ambiguous. Verscheiden may mean 'differing' but can also mean 'disparate'. The noun middelen ('means') may indeed be a noun, but it may also be a verb, and then it means 'to take a middle road', 'to negotiate'. In its most radical sense, the entire sentence then becomes: 'Wisdom is one and the same; teaching, in negotiating, is disparate'. This would not just be any teaching of course; it would be Van den Enden's.

Especially line 3 is telling. We have just learned that wisdom, in being one, speaks in church, school, and theater. Then Vondel ends line 3 with hier ontbreekt ('here lacks'). The enjambment suggests that such wisdom is lacking, although the 'here' is later filled in, by specifying that wisdom 'lacks neither tongue nor speech.' Still, the 'here lacks' stands, and is reinforced when Vondel immediately proceeds to say that wisdom may also speak silently, by mute signs. Why would he make this move if the poem is aimed at praising an actor performing a play that consisted predominantly of speaking? The sentence 'Here lacks neither tongue nor speech' may start

332 Vondel, Toneelkrans Voor den Edelen Jongkhere, Nicolaes van Vlooswijck, ll. 24-38, WB VIII, p. 570. In the original: 'De wijsheit is een zelve, 't onderwijzen / In middelen verscheiden. Wijsheit spreeckt / In kercke, schoole, en schouburg: hier ontbreeckt / Geen tong, noch spraeck. zy kan oock zwijgend wercken / In 's menschen hart, en preeckt door stomme mercken: / Want boeckstaef, verf, en print haer' zin beduit, / En beelt voor oogh en brein haer ooghmerck uit. / Zy dreigt, en noodt door straffen, en belooning, / In schilderye of levende vertooning / Van goet en quaet, naer elx verscheiden aert, / Dat dwaelenden te recht brengt en herbaert. / Zoo moet uw jeugt, gelijck een bloem, opluicken, / En 's levens lent tot's burgers heil gebruicken. / Wie vroegh aldus de slangen worgen kan, / Ontwast de schoole, en wort een Staetnut man. 
to mean something else in this context. Evidently, Van den Enden did enough talking. The question is: should he not have remained silent? The point is made explicit in line 9. There wisdom speaks through painting and vertooning: a word indicating a theatrical performance as tableau vivant. This is precisely what Philedonius was not; rather, it was an extended form of responsive monologue.

The end of the poem wraps all this up. Vondel first puns, again-he also started the poem with it - on the name of the young man: 'Vloos' in Vlooswijck resembles the Latin flos: flower. Let this flower flourish, the poet wishes, so that he becomes a true man of state. But almost out of the blue, the beautiful and peaceful image of a budding flower is contrasted with a young man who strangles snakes. 'Let him grow out of this school', the poet adds, so that he becomes a man who can usefully serve the state, or is worthy of it. The reference to Hercules may be clear, who as a child strangled the snakes that had come into his cradle. Equally clear may be the juxtaposition of the young man who has to kill the snakes in order to outgrow the school. In the Christian context snakes can only have one meaning: evil. So, the suggestion is that this school is where evil lurks.

At first sight, the title character of Van den Enden's Philedonius appears to fit in the common Christian narrative frame of a lust-seeker who has to learn the right lesson in order to become a righteous man or, more specifically, a worthy citizen of the state. He has to reject lust. But this Christian reading becomes rather absurd if one knows that only five years later Van den Enden would sketch a society that is ideal because it knows no Christianity and would espouse the abolition of religion, the place of which should be taken by the school. Indeed, in sketching the life and habits of the Indians in North America, the Naturellen ('those who live according to their nature'), Van den Enden indicates that they do not have a religion. Marriage, for instance, is not sacred. Divorce is a heel gewoonelijck, en gebruikelijk dingh ('a very ordinary and common matter'). This is why Christianizing the Indians is despicable, according to Van den Enden. Christians are nothing but pretenders, propagating 'partly opaque, self-made ornamented, and by consequence also often incomprehensible, artificial articles of superstition, or axioms'.333 This hardly sounds like a man who would teach the rejection of well-being, or who would criticize lust for the sake of Christian righteousness.

Moreover, after the Philedonius performance, Van den Enden produced a play by the classical Roman comedy writer Terence, Eunuchus, in 1658. In 
this performance the female characters were played by his female students (including the character who is raped). Although female actors had entered the Amsterdam stage from 1655 onwards, in this case it fitted in with Van den Enden's ideas that boys and girls should be educated together and that female teachers should be implemented. In the eyes of his contemporaries, particularly in the eyes of the Calvinists, such things were controversial. ${ }^{334}$ And not only the orthodox Calvinists were upset by these kinds of ideas and practices. It is said that Spinoza was involved in the production of the Terence play as a student of Van den Enden, and was perhaps even accompanied by him when leaving the theater, when he was attacked by an orthodox Jew. ${ }^{335}$ In this case, the attack was also aimed at someone reputed to be, at the very least, on his way to becoming an atheist: walking evil.

Even if the plays written and produced by Van den Enden did not address controversial issues directly and were performed for a select audience, they clearly took place in a highly charged controversy, which is different from a debate. In this context, the status of school drama is of particular relevance to the architecture in which it took place, or better: the architectonics of its performance. Firstly, two concrete spaces are involved: the space of the school, in the heart of the city at het Singel, and the space of the city theater. Both spaces have their own interiors, but one is distinctly more private. Although publicly accessible, Van den Enden's school was a private school, with private aims and principles in which things were being done. In the privacy of the school the inclusion of female students, for instance, was one such doing. Furthermore, such doings also involved acting. As I have discussed elsewhere, the school drama is a full-blown form of art with considerable revolutionary potential..$^{36}$

The differences from later and especially nineteenth-century forms of bourgeois subjectivity are distinct, here, also in terms of urban architecture. When dealing, for instance, with the forms of display and theatricality in nineteenth-century Paris, Walter Benjamin considered the notions of theater and illusion in relation to world and universe, which were closely connected to the urban environment under Louis Philippe, the 'Citizen King'. Benjamin claimed that for the first time in European history-not just in the period between 1830 and 1848 but also in its aftermath-the 'place of dwelling' began to be opposed to the 'place of work'. The interior of the former allowed the individual to 'sustain him in his illusions' as opposed

334 On this, see P.H. van Moerkerken, Adriaan Koerbagh, p. 12.

335 Steven Nadler, Spinoza: A Life, pp. 110-111.

336 See Korsten, "'But did they not, with it, burn the excrements as well?"'. 
to his dealings with harsh reality in the office. Commercial and social complexities were being kept out of the place of dwelling. Consequently:

From this arise the phantasmagorias of the interior-which for the private man represents the universe. In the interior he brings together the far away and long ago. His living room is a box in the theater of the world. ${ }^{337}$

With this box in 'the theater of the world' the familiar metaphor of the theatrum mundi is alluded to. According to Benjamin, nineteenth-century private man (the bourgeois citizen) lives in his private box, from which he enjoys his internal theater of projections, fantasies, and illusions. The classical meaning of the theatrum mundi metaphor - that the world is nothing but illusion - is revitalized here in a Marxian sense (despite the fact that capitalism had yet to achieve its hegemony). As Benjamin's close friend Adorno explained it, subjects living under the rule of capitalism cannot see the world for what it really is because they are the objects of other forces, as a result of which they are forced to live in untruth.

Having the best and brightest of the Amsterdam bourgeois elite under his guidance, Van den Enden could give them a training as citizens that was radically un-bourgeois in the nineteenth-century sense and in which drama was used to show them the truth. In the privacy of Van den Enden's school, revolutionary ideas were aimed at a distinct brand of disillusionment, by means of which a new kind of world could be explored, discussed and acted out. In this context, I read the performance of Philedonius in the city theater as a highly ambiguous one. It is a play that speaks in different tongues. On the one hand, in the interior space of the school, the inexpressible could be dramatically expressed. On the other hand, in the public space of the theater, the inexpressible had to be expressed in a veiled way, in a secret language that could only be understood by those willing to understand. Those who were not, would either fall into the trap of allegory, understanding Philedonius to be an allegorical play about the Christian soul struggling for salvation and wisdom. Or they would sense that something was 'wrong', but what exactly? Vondel clearly belonged to the latter part of the audience, as did Joachim Oudaen, who would reflect on both Van den Enden's teachings and the play in an extremely critical way. ${ }^{33^{8}}$ Vondel

337 Walter Benjamin, Selected Writings $1935^{-1938, ~ p . ~} 3^{8}$.

338 A poem by Oudaen ends with: 'Wat baat het of men dan gerust en zorgeloos / De losse jeugt zich doet verlustigen een poos, / Met Philedonius zyn rol te laten spelen, / En in hun ziel-verderf 
perhaps even understood the implications of a protagonist who is the 'friend of well-being'. Understanding it, he in part rejected it, although he as well could not really say what he meant.

Public debates related, then, on the one hand, to concrete architectural spaces and institutions in the urban environment: a school or a theater. On the other hand, there was the architectonic of individuals and collectives, of private spaces and public ones, and especially interior spaces that worked differently. The school space of Van den Enden served the public. It was, as I have mentioned, publicly accessible. Yet, it also had a privacy that was unknown to the theater. In the school space, drama helped students to develop their own interior ideas and worldviews. The theater was publicly accessible to all and consequently demanded a shift in privacy. What was publicly shown was to be understood both collectively and privately. So, in terms of architecture in the seventeenth-century Dutch Republic, certain spaces mixed dwelling and working with playing in the sense of play-acting. Moreover, alongside the urban architecture, there was an architectonic at work that shaped the dynamic between individual internal drama and collective imagination, and both in turn were linked to an external world-theater. This dynamic was decisively 'bourgeois', though not in the nineteenth-century sense.

In this context, the classical linkage of theater with illusion was redefined in opposing terms. The rather simple shift of the school drama, from being developed and worked out in school to being performed in the city theater, points to a decisive split in the concept of performance. On the one hand, performance concerns theatricality, where the emphasis lies on theatricality in the public realm, as a 'vision machine'. 339 Some kind of world is made to be shown and seen, and as a consequence can be reflected upon. The dominant questions here are: how can we know this world that appears split between those who perform and who watch, and how is the subjectivity of both involved? On the other hand, performance concerns 'dramatization', where the emphasis lies on enactment. In a performance, something is being done together, playfully and creatively acted out. The major questions here are: what is the world that is being made in play-acting, and what are its consequences for the constitution of the acting subjects?

I will explore the consequences of this split in relation to the world as a theater or as dramatic space, or (as we saw in chapter 5 ) as a scene.

des dootslaaps hen te streelen.' That is: 'What gain is there if, carelessly and in trust / one lets free youth enjoy itself for a while / with letting Philedonius play his part / and to cherish them in the death sleep of their soul's corruption'. Joachim Oudaen, Poezy, vol. 2, p. 222.

339 Maaike Bleeker, 'Being Angela Merkel.' 


\subsection{Dramatization: Theatrum mundi versus mundus dramaticus}

When Friedrich Nietzsche deals with Greek drama in his study on the birth of tragedy, he does so in terms of theatricality. His major concern is how the socio-cultural domain is organized by means of perspective, by orchestrated vision. ${ }^{340}$ Likewise, as we have seen above, Benjamin was concerned with the organization of perspectives and projections in relation to the metaphor of the theater of the world. Indeed, the theatrum mundi metaphor has proven to be such a powerful one because it immediately calls up the idea that we can put the world itself in perspective. The very notion of perspective suggests subjectivity and mastery. There is a point from which things are perspectivized and such perspective, in turn, with the mastery it implies, relates to the distinction between reality and illusion, and by analogy between truth and falsity. This runs counter to a definition of theater offered by Maaike Bleeker who calls it, a 'critical vision machine' that is not 'a matter of spectacle, exaggeration, or make-believe but a matter of becoming aware of how we are implicated within that which we see and how we see it, and how this in turn is implicated in the performance of others addressing us'. ${ }^{341}$ Here the issue of mutual implication is far more important, which comes closer to what I term dramatization.

Although the two are closely related, theatricality is distinctively different here from drama. Drama does not require organization in terms of perspective at all. In fact, drama does not even require a theater audience. The metaphor of the theatrum mundi focused on the audience as the double subject of perspective - namely, as the viewer and as the subject of the the vanishing point..$^{342}$ In contrast, the idea of drama focuses on those who act, are doing something, even if that doing is playing. The difference is hinted at in Van Stipriaan's study on the theatrum mundi metaphor, in which he emphasizes the playful nature or ambiguity of several seventeenth-century plays. Too often, Van Stipriaan states, the Renaissance has been considered 'a thoroughly didactic era, in which play can be the vehicle of morality at best'. In contrast, Van Stipriaan calls the Dutch seventeenth century a

340 On this see Gary Shapiro, Archaeologies of Vision, chapter 4, 'Übersehen: Architecture and Excess in the Theater of Dionysos' and Chapter 5, 'In the Twinkling of an Eye: Zarathustra on the Gaze and the Glance'.

341 Maaike Bleeker, 'Being Angela Merkel.' p. 259. For a broader underpinning of Bleeker's understanding of theatricality, see her Visuality in the Theater.

$342 \mathrm{On}$ the relation between baroque mise-en-scène, perspective, and the production of subjectivity, see Hanneke Grootenboer, The Rhetoric of Perspective. 
'playful-theatrical culture'. ${ }^{343}$ The crux here is that playing is not something to be seen through in search of what is real, but that the interplay of illusions may lead the well-informed to both enjoy the play and to contemplate truth or adequately judge the real state of affairs. Yet, with the latter, Van Stipriaan returns again to the dynamic of illusion and truth as a result of which drama, as the domain of acting-in-playing, is no longer the issue.

The focus on drama, on doing, was crucial to most humanists who wrote school dramas. This holds for Gnapheus, for Macropedius and, more in terms of theory, for Erasmus. In the seventeenth-century baroque, however, the turn toward drama gains a philosophical and novel meaning, as the work of Van den Enden, and later also Spinoza, may show. Both saw illusions as either unfortunate elements of religion, as a lack of knowledge proper, or as the conscious forms of manipulation by those in power. Especially Van den Enden loved theater, but not as a play of illusions. He loved it for what one could do with it by means of drama - that is, by doing, by acting. This had its consequences for the idea of a 'world'. For both Van den Enden and Spinoza the world was not so much a stage upon which people would play their role. Rather, the world was dramatic itself: a mundus dramaticus. This is, at least, what I would like to call it, following Deleuze's ideas on dramatization (see chapter 1 ).

Let me make clear, here, that I am using dramatization in a different sense than, for instance, Allan Nadler in his study on Spinoza. On Spinoza's attitude toward the theater, going back to the time he was attacked leaving the Amsterdam theater, Nadler states:

It's a safe bet that Spinoza never again darkened the door of any theater. Not so much because of any post-traumatic association, but because of his utter disinterest in all things dramatic (the fanatically rationalist Spinoza famously disdained the imagination as the root of all human ignorance and misery). ${ }^{344}$

Nadler is a bit too quick, here, in his handling of Spinoza's ideas on imaginatio, especially in its relation to intellectus. As becomes clear from reading Ethics or Tractatus de emendatione intellectus, for Spinoza, imagination played a crucial role in the build-up of human knowledge. Don Garrett describes this as follows: 
His use of the term 'imagination' is broad enough to include sensation as well as mental imagery and to include modalities of bodily representation that do not represent shape. He goes on to identify imagination as the first and lowest of the three kinds of knowledge or cognition [cognitio], with the intellect (constituted by distinct and adequate ideas) providing the higher (second and third) kinds of knowledge. ${ }^{345}$

So imagination is a category of sensation - and an indispensable one at that-in the path toward true knowledge. It can materialize in the shape of mental imagery, and can capture modalities of bodily representation that do not represent a concrete, recognizable shape 'out there'. In this way, imagination escapes the logic of representation. Because of its bodily locus in terms of sensibility, because of its bodily activity, and because it falls outside the realm of representation proper, I read Spinoza's use of the concept in light of what I call dramatization. Imagination, in this context, is not something one has, but something one enacts.

In one of his more enigmatic texts Gilles Deleuze asks what kind of agency is involved in the method of dramatization..$^{346}$ The text was a lecture before an audience of colleagues and their questions testify to the text's enigmatic character, perhaps because Deleuze himself uses both the notions of theater and drama. The enigma may also be the result of a principal shift. Taking Plato's idea as his starting point, Deleuze at first seems to start from the realm (and the logic) of representation, as when an idea is represented in the real world. With hindsight one must conclude that he in fact starts with Plato because, essentially, the latter's conceptualization of ideas does not fit a logic of representation at all. With Plato one jumps from something that cannot be present as idea to a form of actualization that borders on it. The impossibility of its presence does not mean that the idea is not real, however. It is real, but not yet actualized, to use a Deleuzian term.

This is why, in analogy, Deleuze can make the move to his distinction between the virtual and the actual. Both are real, but they differ in terms of epistemology and ontology. The way in which the virtual becomes actualized, by some form of agency or dynamism, is what Deleuze calls 'dramatization'. How does this work? This is Deleuze speaking:

345 Don Garrett, 'Representation and consciousness in Spinoza's naturalistic theory of the imagination'.

346 Deleuze, 'The method of dramatization'. In it, Deleuze explains in brief what his study into repetition and difference amounted to. For a short introduction to the concept, see Stephen Zepke, 'Becoming a Citizen of the World'. 
Dynamisms, and their concomitants, work beneath all the qualified forms and extensions of representation, and constitute, rather than an outline, a set of abstract lines coming out of an unexpected and informal depth. A strange theater made of pure determinations, activating space and time, acting directly on the soul, having larvae as actors-and for which Artaud chose the word 'cruelty'. These abstract lines form a drama which corresponds to such a concept, and which directs both its specification and division. Scientific knowledge, but also the dream, and also things in themselves, dramatise.

To be clear, there is no stage, here, by means of which something is represented. It is a dynamism itself: a drama evolving between agents and forces which effectively leads to the actualization of something. Crucially, Deleuze is concerned with a theater of non-representation, and in the questions that follow the lecture it becomes evident how much confusion this concept provokes. For all participants in the discussion it seems to be self-evident that dramatization must fit in a theatrical, perhaps even tragic, and in any case representational paradigm. Without saying this in any explicit terms, however, Deleuze is predominantly concerned with the question of how to define what might be the new in an immanent world, which is also why he is interested in 'the dark precursor', the invisible path that is already being made before lightning strikes.

In the change from virtual to actual something new is produced. We can know what is new because, paradoxically, it represents something that does not fall under the rubric of representation (yet). This is also why we cannot consciously act toward it, for then we would already know it; it would be possible, as Deleuze would argue. In contrast, it is through play-acting that we can stumble across the new, or can produce it unexpectedly.

Just as theatricality is related to theater but not restricted to the domain of theater, so dramatization is related to drama but not restricted to its domain. Van den Enden's text Free Political Propositions and Considerations of State proves as much. In the preamble to this text Van den Enden admits that he would never have thought of writing something about this topic, had he not been asked to act as a mediator for a group of Dutch citizens who, tellingly, wanted to start a new life elsewhere. What this new life would be, and how it could be defined, was not that clear at all when they asked Van den Enden for help. They started to play/act together, every party taking its part. It was in this play/acting together that Van den Enden found something new. As he expresses it himself: 
Up until the year 1661, I had never had the least thought to ever let any letter in writing about political matters appear in the light of day, had it not been that, as unexpectedly as un-thought of, a possibility appeared to me to ask, for a small number of people in need, for an expedition to New Netherlands with the thereto appointed Chamber of Colonies in this city. ${ }^{347}$

Whether Van den Enden was asked to act as a mediator, or whether he proposed to take on this role himself, he started from the position of the 'un-thought' — started to act, entering a discussion that radically surpassed the simple case concerned. In taking this role, Van den Enden, in both describing and imagining a new world, would stumble into the 'new' which would lead him to sketch the world anew.

Regarding such description, my argument can be related here to a study which was controversial at the time of its publication: Svetlana Alpers' The art of describing: Dutch art in the seventeenth century (1983). As may have become clear in my consideration of Frans Hals' work (see chapter 4), I agree with Alpers that the scholarly treatment of baroque art has been suffering from what are ultimately too emblematic or moralistic interpretations. Baroque art was, indeed, also intrinsically descriptive. Yet, as the case of Van den Enden may prove, the Dutch Republican baroque attitude was not so much a matter of description, but helped to actualize worlds in a more general dynamic in which it took part. The Republic and Amsterdam did not just find their place in an already established world, but actualized a world, a new world scene in which the New World on the other side of the Atlantic found itself together with the 'old' one.

By using the verb 'actualize', I take my cue from a kindred pair of distinctions made by Hannah Arendt and Gilles Deleuze, respectively, between two modes of 'making'. Following Arendt's distinction between acting and making in The Human Condition, the Republic and Amsterdam were not making history, as if it could be made like a house, according to a plan. Instead, due to their own political, economic, aesthetic, and often dramatic actions and acting, the Republic and Amsterdam did not just stumble into an already existing world but actualized one-politically, juridically, and aesthetically. As for Deleuze, his problem was how to explain the 'new' in a

347 Van den Enden, Vrije politijke stellingen, p. 125. In the original: 'Voor het laest van 't jaer 1661. had ik noch gheen de minste ghedachte, van oyt eenige de minste letter schrifts over politijke zaken in 't licht, of aen den dach te geeven, tot dat my, zo onverwachts, als onverdachts gelegenheit, om voor zeekere weinige en verleegen lieden eenigh waerdig expedient na NieuwNeederlandt aen dezestats ghewezen Colonies-kamer te verzoeken, voorquam.' 
Spinozist, radically immanent world. In order to solve this, he distinguished between the virtual and the actual, with the virtual not being not-real, but real and not-yet-actualized. To him, dramatic action would bring in difference and the new. ${ }^{348}$

This is why the theatrum mundi metaphor may no longer be apt to describe what happened in the seventeenth-century Dutch Republic. Here, the world was no longer a stage that one could look at from the perspective of the real or the Real. Instead, the world itself was dramatized by play-acting with and in the real, and thus it turned into a mundus dramaticus. The one did not replace the other. Just as classicism and the baroque existed next to one another (with the baroque emerging victorious from their entanglement) so did the two metaphors. This coexistence or coincidence can be traced in a famous work by Constantijn Huygens (1596-1687), secretary to stadholders Frederick Henry and William II, diplomat, composer, musician, architect, gardener, and writer.

\subsection{Fluid borders between theatricality and dramatization: Huygens' 'Sunday'}

Constantijn Huygens' lengthy poem Oogentroost (literally: Eyes-comfort) took the blindness of one of his best friends as a theme. Regarding this theme, his poem did not present a coherent and consistently developed image since the poem was connected to a complicated intertextual web. ${ }^{349}$ Regarding that web, a simple look at the Bible Concordant will suffice, as Jürgen Pieters argued, to see how blindness can be read in opposite ways. On the one hand, it is a matter of sin: the blind will not and cannot see. On the other hand, blindness may indicate deep and superior insight, because the blind can spiritually see what those who are blinded by reality cannot..$^{35^{\circ}}$ It is here that blindness corresponds with allegory. It connotes seeing differently. As may be have become clear in chapter 6, I am more interested in the literal, as it connotes baroque materiality or texture. ${ }^{35^{1}}$ In

348 For a both fruitful and insightful dealing with the Dutch baroque in terms of Deleuze's dramatization, see Marrigje Paijmans, Dichter bij de waarheid.

349 This intertextual web in Huygens' Oogentroost was the object of research for a group of scholars led by Jürgen Pieters. On the project see: http://www.nederlandseliteratuur.ugent.be/ onderzoek/Ooghentroost

350 My translation. See Jürgen Pieters, 'In denkbeeldige tegenwoordigheid'.

$35^{1}$ In a recent debate on the responses to Coetzee's novel Disgrace the distinction between the literal and the figural appeared to be pivotal. In J.M. Coetzee and the Ethics of Reading, Derek 
this context, a third form of blindness emerges: that of the dream in which our eyes do not see, but images present themselves nevertheless.

Such a dreamlike situation is evident in a famous poem by Constantijn Huygens, taken from Heilighe Daghen (Holy Days, 1645), entitled Sunday:

Is it Sabbath, my Soul, or Sunday? None of the two.

The Sabbath is gone with its obligations:

And the sun that I see, shone yesterday as it does today.

But the one I do not see does not shine as it seems.

Sun, that I do not see but through my sins,

Son of God, who on this day comes to tread on earth,

Proud as a Bridegroom entering the main road,

I see a Sunday without end, through your Wounds.

So if it is Sunday now as well, one may call it God's Sonday,

Yes, and God's Sootheday too. But let me curse us,

For whichever of the three I turn to I find us in guilt.

God Sun, God Son, God Soothe, how long does your patience last?

How long will you suffer, Lord, your Sonday, Sootheday, Sunday,

Ungraciously being spilled, spoiled, misspelled in Sinday? ${ }^{352}$

Luckily enough, the English words sun, son, and sin allow for a translation of Huygens' experiment with language. I had more trouble finding an

Attridge strongly defended a mode of literal reading, since most responses to Disgrace were, so he argues, allegorical. It was as if everything particular that happened in the novel was to be read as a reflection on the more general or deeper state of affairs in South Africa. This allegorical obsession framed the potential of the novel by a presupposed 'other' meaning. We should strive, so Attridge argued, to read things more at face value in order to sense what the novel is actually doing. In his response to this analysis Ernst van Alphen goes a long way in following Attridge but in the end points rightly to the dichotomy that Attridge uses to make his point (see van Alphen, 'Affective Operations of Art and Literature'). There is no language without meaning, and even literal meaning is, indeed, meaning.

352 In the original: 'Is 't Sabbath dag, mijn Ziel, of Sondagh? geen van tween. / De Sabbath is voorbij met sijne dienstbaerheden: / En de sonn die ick sie scheen gisteren als heden. / Maer die ick niet en sie en schijnt niet soo se scheen. / Son, die ick niet en sie als door mijn' sonden heen, / Soon Gods, die desen dagh het aerdrijck weer betreedden, / Fier als een Bruijdegom ter loop-baen ingereden, / 'Ksie Sondagh sonder end, door dijne Wonden heen. / 'tZij dan oock Sondagh nu, men magh't Gods Soon-dagh noemen, / Ia, en Gods Soen-dagh toe. Maer laet ick ons verdoemen, / Waer ick van drijen gae ick vind ons inde Schuld. / God Son, God Soon, God Soen, hoe langh duert dijn geduld? / Hoe langhe lijdt ghij, Heer, dijn' Soondagh, Soendagh, Sondagh, / Ondanckbaerlick verspilt, verspeelt, verspelt in Sond-dagh'. For the text, see: http://www.let. leidenuniv.nl/Dutch/Huygens/HeiligeDagen.html. For another translation by P.J. Large see: http://www.hull.ac.uk/php/abspjl/Dutch/Huygens/Willig.html 
equivalent for the word zoen, from verzoenen, indicating Redemption day, but meaning, literally, to reconcile. I translated it as soothe, which connotes the archaic sooth (truth or fact), and which means 'soften' or 'mitigate'. Accordingly, the four versions of Huygens's day correspond in English with sunday, sonday, sinday, and sootheday.

The most common reading of or response to this poem has been an allegorical one, aimed at defining the poem's real or ultimate meaning, as is illustrated, for instance, by the website of the Royal Library. ${ }^{353}$ Indeed, the poem itself almost enforces this allegorical route. Much like in Huygens' Oogentroost, a visual dynamic is installed in line 3 with the 'I see'. This seeing is defined first empirically or realistically. The sun that the 'I' could see yesterday is the same as the sun that he can see today. But after that, almost naturally, the allegorical reading is provoked by line 4, where sight is blocked, or where an appeal is made to that which one cannot see.

Now, the allegorical impulse is about defining what lies beyond what 'seems' to be the case. Note, however, that in this case the 'I' need not see behind, but through the clouds of his sins, like he must later see in and through the wounds of Jesus. This 'through' opens up a rather different meaning and a different way of relating to the world, for it replaces space with texture. In my reading, Huygens' poem is an exploration of closeness, of a direct confrontation that is not an issue of everyday affairs but a dramatic one, involving all the senses in a situation in which something is acted out.

Heightened awareness is installed with the very first line, where the ' $\mathrm{I}$ ' wonders what this Sunday is. The world of everyday reality, with its own historical pathways and parties, has not disappeared but is intensified in relation to the ontological issue of something that is happening, here and now. On the face of it, the sun shines today as it did yesterday. Yet, there is a shift in texture, from line 5 onward. It is not behind his sins that the 'I' has to see, as if there is a truer reality behind things. The sun shines through the sins of the 'I' and in this shining through an actor appears: Jesus, turning sun into son, and turning the situation into a here-and-now, 'on this day'. The intensity or heightened awareness of what is happening shifts the time-scale in relation to the question of how what is happening will result in something and come to mean something. Time is intensified, binding

353 See: http://www.kb.nl/dichters/huygens/huygens-o6.html. See also FrankJ. Warnke, 'Sacred Play: Baroque Poetic Play'. For a less allegorical, and more contextual interpretation, see the introduction by L. Strengholt in Constantijn Huygens, Heilighe daghen, or Rita Verbrugge, 'Huygens' Pilgrimage Through the Calendar Year'. 
moment and eternity, turning the moment into something 'without end', which is emphasized in the following line by the concentration of the 'now'. The dramatic nature of the situation is highlighted in line 11, where the 'I' turns to the three possibilities, one by one, and where he is implicated by the three, through which 'I find us in guilt'.

At the same time there is a fluid transition here from the dramatic situation to a theatrical one. Moving forward, the lyrical ' $I$ ' leaves the realm of heightened awareness, for he starts to wonder how long this situation of triple misuse will last. With this conclusion the drama of the situation is lifted and we enter a theatrical framing. We are no longer implicated in what we see, but look at something from a reflexive distance. The eye has left the telescope, the dream is lifted, the dramatic situation is now framed theatrically. This is captured in line 12 with an address to God which, at the same time, introduces the theatrical actors that are lyrically invoked: 'God Sun, God Son, God Soothe'.

Earlier, I quoted Maaike Bleeker's definition of the theatrical as 'a matter of becoming aware of how we are implicated within that what we see and how we see it'. ${ }^{354}$ The key term here is 'implicated', or, to put it in material terms, 'entangled in', 'woven into'. Theatricality and dramatization differ in that the former entails a distribution between those who act and those who view, under a visually dominant frame that defines and splits a space. The latter indicates something being acted out on some sort of podium on which all actors are involved, sensually linked in a situation that defines the texture of time and history. On such a podium, the moment of attention is a moment when looking, seeing, and sensing position human subjects as dramatically implicated in a world the texture of which they can feel, in an intensified awareness, both intensifying time and expanding it, without knowing as yet what it all means or what it will lead to. That moment comes to be fluidly interwoven with a theatrical moment of reflection, where problems of the past are related to problems of the future, in a temporality that is cut up into past, present, and future, and that is measured in lengths, as when the lyrical 'I' asks: 'How long' to go? As such, Constantijn Huygens' Sunday is exemplary of the mutual implication of theatrum mundi and mundus dramaticus.

In this case, the entanglement of the two metaphors gave rise to a dreamlike situation. In the next and final chapter I will be focusing on principal differences between the two in terms of their potentials to produce or safeguard a distinct world, with a distinct organization. 
This content downloaded from 132.229.156.144 on Tue, 05 Feb 2019 10:43:02 UTC All use subject to https://about.jstor.org/terms 


\section{Interrupting time for the sake of division: history and the tableau vivant - Rembrandt (Abraham and Isaac), Quast, Vondel, and Vos}

\subsection{Abraham and Isaac: the opening of history through the what-if}

Three of the greatest baroque artists, Caravaggio (1571-1610), Rubens (15771640), and Rembrandt (1606-1669), each made several drawings, etchings, and paintings of the story of Abraham and Isaac, especially of the moment at which Abraham is stopped from killing his son. In contrast, they paid much less attention to the biblical figure of Job, whom we met in chapter 2 . As explained there, the biblical figure of Job was one of the most important socio-cultural heroes in the Middle Ages, and at times even the greatest hero. Yet after flares of attention in the sixteenth century his dominance and importance diminished in the course of the seventeenth century. Compared to his pervasive presence in the Middle Ages and sixteenth century, Job grew nearly invisible towards the eighteenth century and would only resurface in the context of symbolism, in the powerful work of William Blake in the early nineteenth century, for instance. He would then become an icon, ironically, of the vexed artist or, in Kierkegaard's 1843 Repetition, a 'teacher of humankind'.355 Job would resurface yet again in Western twentieth-century literature and philosophy in the context of, unsurprisingly, reconsidering philosophy's relation to theology. For now, however, the question is: why did the story of Abraham and Isaac become more dominant than Job's in the Dutch republican baroque? Especially the moment when Isaac's sacrifice is stopped became a favorite topic of artistic consideration throughout Europe and in the Republic. The hypothesis put forward in this chapter is that Abraham and Isaac were dramatic figures, embodying the potential inherent in a decisive moment: a moment of bifurcation.

355 On Blake's fascination with Job, see Harold Bloom, Neil Heims, and Heather Dubnick, eds., William Blake. Or, see W.T. Mitchell on Blake's idiosyncratic use of the story: W.T. Mitchell, Blake's Composite Art. On Kierkegaard, see Edward F. Mooney, 'Kierkegaard's Job Discourse: Getting Back the World'. 
The theme of Abraham's dilemma, sacrificing or not sacrificing Isaac, was intensely studied by Rembrandt in etchings, sketches, and paintings. The following etching from around 1637 entitled Father Abraham playing with his son is particularly relevant because it shows the story's ambiguities and implications as charged in terms of a what-if, that is to say: in terms of that which we wish would have been the case (see figure 20). The title of the etching, Father Abraham playing with his son, is remarkable for the explicit addition of 'Father'. To an audience that was thoroughly familiar with the story this addition would have been almost absurd. Unless, of course, the very fatherly-ness of Abraham is at stake in this etching. As if to emphasize this, instead of really playing with his son as a father would, Abraham is more concerned with intensely addressing the viewer. This very address brings in another meaning of 'play', where Abraham is not playing with Isaac but with the latter's life. Consequently, he is intensely asking other subjects what they think of him and his possible act.

The dramatic confrontation at stake here has been veiled or explained away in the history of the etching's title which, in 1679 in an inventory of print-seller Clement de Jonghe's estate, under no. 25, was mentioned as: 'Vaeder Abraham speelend met sijn soon' ${ }^{35^{6}}$ Yet, the etching has been reinterpreted as 'Jacob caressing Benjamin', on the basis of a similarity with a drawing that depicts Jacob holding Benjamin lovingly while listening to Joseph. The drawing concerned is Joseph tells his dreams to Jacob, dated 1642 (see figure 21).357 The similarity between the two may be evident but this is something else than reducing two different works, two different histories, and by implication two different worlds to one so-called coherent one, metonymically entitled 'Rembrandt'. Nevertheless, the scholarly attempt to collapse two possibilities down to one, was so successful that the etching can now be found on the Internet most easily under its new, enforced name. Still, I see no reason to change the title given to this etching in a catalogue no more than ten years after Rembrandt's death. It was given, moreover, by someone who was a close friend and collaborator of Rembrandt's. I see no reason, that is, to change the original title merely because of its resemblance with another work (a drawing that was made five years after the etching).

The most fascinating detail of the etching, especially in the context of the what-if, is the forefinger of Abraham's hand under Isaacs chin — or rather, at his throat. The movement of both caressing and cutting is suggested strongly by the position of a button on Isaac's coat but that also looks, at a 
glance, like a loose little finger from Abraham's hand, what Žižek would call an 'organ without body' (see figure 22). ${ }^{35^{8}}$ Due to the position of the button / loose little finger, the hand is not tranquil, as if in a position of caressing, but rather resembles the hand of someone holding a knife, suggesting a cutting movement to the left. Thus, the caressing hand in the narrative's present is at the same time the throat cutting hand in a narrative prolepsis: it shows now what will come later in the story. The combination of Abraham looking at the viewer and the hand suggesting a cut presents an intricate mixture of a conditional and a counterfactual.

In the context of the Delft Thunderclap (see chapter 1), a conditional could have been, based on the supposition that the explosion was ignited by, for example, a fallen candle: 'If someone had not entered the storehouse carrying a candle, the gunpowder would not have exploded.' A counterfactual would then be: 'Despite the fact that someone took a candle inside, the gunpowder did not explode.' One may see how close the two are, since a change in emphasis makes the first sentence border on a counterfactual, as when the emphasis is laid on the first 'not': If someone had not entered the storehouse carrying a candle...' With the Rembrandt etching, the conditional at stake is: 'If God had not ordered Abraham to sacrifice his own son, Abraham would not have had the idea to kill Isaac.' The counterfactual is: 'Despite the fact that God ordered Abraham to kill his own son, Abraham did not set out on his journey to do this.' A Jewish commentator, such as the late thirteenth to early fourteenth-century rabbi Joseph ben Jacob Kaspi, might have added another counterfactual: 'Abraham wrongly considered the voice he heard to be God's instead of an imaginary one, which is why he did not follow God's command but his own delusion'.359 The conditional and the counterfactual, despite their possible slippage into one another, relate to reality in radically different ways. The conditional relates to the condition and by implication necessity that is required for one reality to be actualized and not another one. A counterfactual implies that factual reality has an equally real partner, or perhaps many partners. So, the counterfactual is not just any imaginary other possibility, such as the possibility that Abraham could also have gone fishing. Rather, the counterfactual relates directly to the factual and is in this respect a factual alternative; it implies a multiplicity of factual realities.

Factuals do not exist as such, however. They require that we interpret things adequately, which was Joseph ben Jacob Kaspi's point: to him 
Abraham acted out of a delusion. At the moment of Abraham's lifting of the knife to cut his son's throat, one would have to be sure of the fact that he was really going to do it, or other factuals and counterfactuals would come into play. If our interpretation is that Abraham was never going to cut his son's throat anyway because he only wanted to find out whether God would intervene or not, this becomes the factual: 'Abraham would never cut his son's throat, whether God intervened or not.' A counterfactual in this case becomes: 'Abraham was not pretending to cut his son's throat but wanted to do it really, whether God intervened or not.' While this may seem a simple play on words, it is not. Interpretations and factuals are intrinsically related, as may have become clear in chapter 5 , where Grotius dealt with the taking of a Portuguese vessel by a Dutch captain in the Indian Ocean. Was this a matter of theft, or was it not? It was not simply what had happened that determined the answer to this question; it was the coincidence of fact and interpretation that mattered.

In connection to conditionals, counterfactuals, and interpretations, the coexistence of worlds was taken seriously by the analytic philosopher David Lewis, who worked on the idea of modal realities from the late 1960 s and was much inspired by the work of baroque philosopher Leibniz. Lewis expressed his ideas for the first time in the early 1970s and developed them fully in his 1986 study On the Plurality of Worlds. Since this idea was clearly baroque in nature, Lewis - being an analytical philosopher-was well aware of the awkwardness of his thesis. This is palpable, for instance, in the following passage, which is taken from a 1970s work in which Lewis is still dealing predominantly with counterfactuals:

When I profess realism about possible worlds, I mean to be taken literally. Possible worlds are what they are, and not some other thing. If asked what sort of thing they are, I cannot give the kind of reply my questioner probably expects: that is, a proposal to reduce possible worlds to something else. I can only ask him to admit that he knows what sort of thing our actual world is, and then explain that possible worlds are more things of that sort, differing not in kind but only in what goes on at them. ${ }^{360}$

In terms of my argument, Lewis is using 'possible' in an unfortunate way here. When he talks about 'possible worlds' this is in relation to actual worlds, taking the vantage point of 'our' actual world and then stating that here are others existing next to it, captured by the above phrase: 'they are

360 David Lewis, Counterfactuals, p. 85 . 
what they are'. Yet, this is precisely why they are no longer possible - they are already real. From within one actual world any other world is possible only in its not yet being actualized. For once it is actualized, it concerns another actual world, one that is split off from 'ours' or that coexists with it. As such, to reiterate, it is no longer possible but actual. This is why I consider the phrase 'possible worlds' to be unfortunate when it is used to indicate actual worlds. In fact, the what-if relates more adequately to the 'possible'. The what-if asks whether things could only have gone this way, and it explores the implications of another possibility. Still, the pivot that connects the counterfactual and the what-if is that we accept the idea that the one actual world is not necessarily the only one, but that it is either one of many potentially actual worlds, or one that could have been different.

Read with multiple realities in mind, the way in which the father figure of Abraham is sketched by Rembrandt comes to embody a duality. In the context of the story, Abraham is shown here not so much theatrically but dramatically, drawing the viewer actively into an action that is, as of yet, only an act of pondering, even as the cutting movement suggests one gruesome possibility of this pondering. As an authoritative father figure, Abraham's course is not predetermined, but a matter of dramatic confrontation that invites the audience to take part in considering what the proper thing to do is. This suggests another kind of authority than the one of the master of the house who is allowed to torture his subjects at will (central to chapters 2 and 3 ). By implication it involves another mode of subjection. God, a master-figure, in asking Abraham to sacrifice his son for no necessary reason follows much the same logic of torture that is at play in Job's story. Abraham, in obeying and setting out to kill his son, is being tortured but is not a torturer himself. Instead, given the situation, he is faced with a dilemma - to either preserve himself or to kill his son-a cruel choice.

This deeply ambiguous, dramatic moment provokes the question of whatif, which in effect runs counter to the idea that only one world is possible. The what-if asks time and again: what might or did dramatically open up a history and world in a different direction? In this way, the what-if provokes what Jean-Pierre Sarrazac defined as retrospection. ${ }^{361}$ Although Sarrazac focused on modern or contemporary drama, his ideas are rather apt to further our understanding of baroque theatricality and dramatization. One reason for this affinity is Sarrazac's stance that modern drama is no

361 Jean-Pierre Sarrazac, Poétique du drame moderne. As the title (Poetics of modern drama) makes clear, this is a study on modern drama, and one that takes an oppositional stance toward Hans-Thies Lehmann's influential ideas on post-dramatic theater. 
longer a drama played out theatrically in life (drame-dans-la-vie); it is the drama of life (drame-de-la-vie). He defines this drama on the basis of a tendency toward:

- retrospection: actors retracing their steps

- anticipation: a play starting from the point of its end

- optation: showing what could have been the case, not what is the case

- repetition/variation: life consisting not of important events but of repetitions with their inevitable variations

- interruptions: the development of a plot being disorganized by introducing a principle of irregularity

In previous chapters (especially 2 and 3 ) some of these tendencies were already pivotal. In this section, above, optation and retrospection were at stake. In the following sections we will deal with interruption, optation, repetition, and anticipation.

\subsection{The virtual: narrative versus interruption}

Interruption may be embodied in the split-second coincidence of two worlds. Such a coincidence is captured in a drawing that Rembrandt made in preparation for his painting of the decisive moment in which Abraham nears the point of cutting Isaac's throat (see figure 23). The drawing is a straightforward preparation for what would become the painting now hanging in St. Petersburg's Hermitage. ${ }^{362}$ In some decisive aspects the drawing embodies multiple realities. Abraham, for instance, seems to have two faces with what appear to be two sets of eyes. There are also two knives involved: one is apparent in what can also be the shape of a rock, the other one is clearly a knife that, due to the forceful interference of the angel, is propelled away from Abraham. Yet, this is only conjecture on the basis of the known story or narrative, which allows for a short detour on the forces of narrative.

Narrative can be related to acting in several ways. First of all, there is the act of telling or narrating. Then, the narrative will consist of what is

362 Another version is ascribed to the studio of Rembrandt, although it does have the inscription Rembrandt. verandert. En overgeschildert. 1636 (Rembrandt, changed. And repainted. 1636). It can be found in München, in the Alte Pinakothek. As the website of the museum indicates: 'There are differences of opinion on the interpretation of the inscription.' http://www.rembrandtdatabase. org/Rembrandt/painting/47376/the-sacrifice-of-abraham 
told about acts, brought into a logico-chronological order on the level of the narrative's history. Furthermore, the bringing forth of a narrative can be seen as an act. The story of Abraham and Isaac did not always exist; there was a situation in which this narrative was brought forward by someone into a socio-cultural or anthropological situation, which may have been a dramatic moment. Finally, an existing narrative can be read and re-read, or re-told, and as such it has performative powers. When I previously related event and moment to theatricality and dramatization, this did not imply that they do not play an equally important role in narratives. Yet, there is a generic difference between showing and telling, and between telling as an act and the acts within a narrative. As soon as a narrative opens up towards the potential of showing, it will become theatrical. As soon as it opens up towards the potential of acting, it will become dramatic. Any narrative tends toward closure, but it can be opened up dramatically time and again. In the case of Rembrandt's drawing, for instance, the narrative is already known. Yet, instead of being retold it is being shown here, theatrically, in relation to a known and logico-chronologically framed event that is dramatically opened up as a moment in which we find ourselves anew.

When Abraham's knife is depicted between hand and possible victim, and with a shadow-knife above it, this is not only a radically new artistic invention in representing the moment, but also opens up the moment as a split-second coincidence of two worlds and two different actualizations. If we take seriously the powers involved in this drawing, the knife may either be moving away from the hand or moving toward it - as if the force of the angel has this dual capacity, and as if Abraham still does not know what the next step is going to be. Seen outside the light of the already established narrative, this drawing truly captures and shows a dramatic moment, considered from within its own 'present', with an unpredictable outcome that will be the result of actors acting and bringing in the new as one actualized world. For the moment, however, there are still two worlds in play.

With respect to the status of baroque multiple realities, I take my cues, as may have become clear in previous chapters, from the baroque philosophers Spinoza and Leibniz. Other sources of inspiration include the twentiethcentury philosophers Deleuze and Lewis mentioned above. The four of them would be highly surprised to find themselves together. No mistake, Leibniz and Spinoza did meet, in The Hague, and exchanged ideas. In his later work though, Leibniz diverted principally from Spinoza. As for the two modern philosophers, Lewis is an analytic philosopher with surprising ideas on modal realities and Deleuze a continental philosopher with radical ideas on the connection between the actual and the virtual. Yet, both modern 
philosophers relate to the baroque. Lewis' ideas were highly influenced by Leibniz's monads. Deleuze wrote a study on the baroque, The fold, which focused explicitly on these monads, but he also wrote two books on Spinoza, in which multiplicity in unity of the real was a key issue: Expressionism of Philosophy:Spinoza and Spinoza:Practical Philosophy. Though I did not deal with these works in detail, they provide the frame for my exploration of the nature of reality in the Dutch baroque. What is of interest in the philosophy of all four thinkers are their considerations of distinct, real worlds that at some point coexist and yet become radically separate at a certain moment, as a matter of actualization.

To be sure, Leibniz's ideas would be hard to translate to the what-if embodied in the story of Abraham and Isaac. For Leibniz, the awkward philosophical issue was that two differently actualized worlds would not be equivalent, because God must have opted for one as the best. ${ }^{3{ }^{63}}$ For Lewis, it was necessary to conceive of multiple worlds. To him, the simple and at the same time complex idea is that what caused, for instance, the explosion of Delft to take place might as well not have taken place. This 'not-happening' would have resulted in another world. Denying the real existence of a different reality, if only for a split second, implies that the world we live in is the only possible world. Dutch Republican baroque art and philosophy show an awareness of this split-second coexistence of realities and a fascination with the intensity of the one reality actualized out of myriad choices. At the basis of this was not an event, but a dramatic moment at which one entered a world that was principally unforeseen, or new. This is what Deleuze would call the jump from the virtual to the actual. In Deleuze's frame of radical immanence, the virtual could not be unreal, for then the very jump would be impossible. It was only not yet actualized.

The multiplicity of worlds embodies freedom. Even when Spinoza rejects contingency, this is not to say that the world has only one predictable outcome. Spinoza rejects contingency if it implies that an outcome will be inexplicable. Yet, it is only explainable with hindsight, when all factors could be taken into consideration. This all differs principally from the standpoint that only one world is possible. To claim that only one world is possible implies that the unimaginable potential inherent in everything that is must be countered, controlled, and foreclosed. 
There is a genre that addresses the tension between these two options: the tableau vivant.

\subsection{A fool waiting for the political moment: tableau vivant between retrospection and anticipation}

The Latin word brutus means heavy or unwieldy, but also dull, stupid, or irrational. So, when someone is named Brutus, this is somewhat ambiguous. The ambiguity of the name is captured best in the figure of Lucius Junius Brutus, who had to survive under the oppressive rule of the Roman king Lucius Tarquinius Superbus. Being the son of the king's sister, Tarquinia, Brutus had seen what the king was capable of in eliminating opponents, and he considered it wise to act the fool (thus becoming the paradigm for Hamlet). After the youngest son of the king, Sextus Tarquinius, raped Lucretia, she revealed this shameful act to a number of male family members, including Brutus, and then committed suicide. The long-term result of her actions was that she became one of the pivotal characters in Renaissance and baroque art. In the shorter term, what had been done to her propelled the permanent overthrow and abolishment of the Roman Kingdom. In 509 BCE, Brutus would become the first consul of what, from then onward, would be a republic in which royalty was equated with tyranny.

As we saw in chapter 2 the Dutch Republic was fascinated by, and struggled with, the Roman paradigm. In this case, the history of Brutus prefigured the history of the Dutch Republic in its revolt against a tyrant. Consequently the story was the topic of tableaux vivants that were shown on the festive occasion of the Twelve Years Truce between the Dutch Republic and the Habsburg Empire under Phillip III, that was signed in April 1609 and would last up until 1621. On 5 May 1609 the festive tableaux vivants were shown at night and lit with torches, one of them representing the history of Brutus, Lucretia, and Tarquinius. ${ }^{364}$ In 1643 Pieter Janszoon Quast (1606-1647) painted this tableau based on a description by the poet P.C. Hooft of the original tableau. Both tableau and painting were entitled The triumph of Folly: Brutus in the figure of a fool before king Tarquinius. ${ }^{365}$ Quast

364 A. Heppner, 'Pieter Quast and P.C. Hooft', p. 370, see also J.A.Worp, Geschiedenis van het drama en van het toneel in Nederland, deel 2, p. 15 .

365 In the original:De triomfder zotheid:Brutus in de gedaante van een zotvoorkoning Tarquinius. Quast made yet another painting on the same subject, see Pieter J.J. van Thiel, 'Moeyaert and Bredero', p. $3^{2 .}$ 
had chosen to paint the tableau because, intertextually, it showed how history could be changed for the better through a revolt against tyranny and the establishment of a republic (see figure 24). The painting of the tableau is a repetition in itself, in that it refers back to the tableau of 1609 . It is also emphatically theatrical, in a double sense of the word. It shows a tableau vivant on the Amsterdam theater stage, which is realistically depicted here, and which was often used to show tableaux vivants. ${ }^{366}$ It is also repetitive in that it shows a piece within the piece, and a stage on a stage. As viewers, we are looking at a theatrical, frozen scene, within which the king on the balcony is watching Brutus making his theatrical appearance. This is the piece within the piece: Brutus is playing the fool before the king. Yet there is also a double stage involved. All characters stand on a stage, but Brutus also stands on the bodies of some fools which form a stage. This is emphasized, or broadened, by the manner in which the other fools are all bent forward, in contrast with the two musicians.

According to A. Heppner, the figures to the left and the right—-the old man with a stick on the right and the young man with a bow on the left-are representations of the most important funders of the theater: the Old Men's House and the Orphan's House. This is certainly one plausible reading. Yet, the old man is also a clear repetition of the well-known figure of the one who 'points out' what a tableau means. As such, he is not a theatrical figure but a kind of teacher. A tableau such as this was often accompanied by leaflets or booklets that explained how one should read the show and the characters ${ }^{367}$ The idea that the young man to the left represents the Amsterdam orphanage is complicated by the fact that he carries a bow and is the only character next to Brutus addressing the audience. Yet, Brutus turns toward the audience in his performance for the king; he is not looking the audience in the eye. The young man with the bow does look the audience in the eye, almost like a dwarf in a Velasquez painting. Thus, he breaks through the theatrical frame, emphasizing the dramatic and violent potential of what is at stake.

In its singularity and as a form of frozen action, the moment that is captured is potentially constitutive. If so, it is an expression of a not yet established or not yet realized sovereign rule by the people: a

366 On this see two articles by B. Albach, 'Drie eeuwen Gysbreght van Aemstel', p. 17, and 'De schouwburg van Jacob van Campen', p. 103-104.

367 Mieke B. Smits-Veldt, 'Vertoningen en opvoeringen van Vondels tragedies 1638-1720', p. 216, referring to W. Hogendoorn. 'Sieraaden van het tooneel, p. 73; ookJ.E. Uitman. 'Les fêtes baroques d'Amsterdam de 1638 à 166o'. 
sovereignty-in-the-making - a form of anticipation. In relation to the very idea of constitution, the frozen moment of the tableau vivant may serve either to cement a distinct order or to radically open it up. History, in this context, is both what has happened, theatrically represented with hindsight as a form of repetition, and what has come to life again, embodying the potential, or the divergent difference, of what can be made by actors that act as the sovereign force in the production of history. In this case the actors producing history are both Brutus and the Roman people. Brutus may be playing the fool here, but he is doing so on the back of a collective, which may represent the people of Rome who are not acting as fools but who are distinctly caught in folly under the rule of a despot. The tableau captures the dynamic, then, between two different and incompatible rulers and the ones they are supposed to serve: the people. And despite the fact that Brutus is shown as an excessively clownish figure here, he is the most, or only, virtuous one of the two rulers.

Since the 12th century scholastic thinkers had defined virtus as a crucial prerequisite for any ruler. Rulers should shun violence (vis) and avoid vices such as avarice and exuberance; this immediately ruled out Tarquinius as an acceptable ruler. Acceptable rulers had to practice the four cardinal virtues that were the embodiment of virtus: justice, prudence, courage (fortitudo), and temperance. An issue on which the medieval scholastics and the later humanists would start to differ was where personal gain fit into all this. Whereas the scholastics tended to emphasize that the ruler needed to remain a humble servant of the community, the Italian humanists would emphasize that a ruler had to strive for fame and glory, an element developed further by Nicollo Machiavelli, in Il Principe, from 1513, for whom the virtuous shifted into the virtuoso.

The Roman author Cicero had claimed that a just ruler must avoid brute force. He must not act beastly, neither with the raw force of the lion nor with the cunning guile of the fox. Machiavelli answered that one can indeed distinguish between human and beastly actions, but people do not live solely in a humane world; they can act beastly. To him, the classic depiction of the prince as a kentauros - half man, half beast - was an apt one. Appropriating Cicero's metaphors, Machiavelli asserts that an effective ruler might best use both the force of the lion and the cleverness or skillfulness of the fox. For there is such a gap between how people ought to live and how they do live that a virtuous prince in the scholastic sense would not be able to preserve himself or the community. Faithfulness, in the temporal or spiritual sense of the word, is all fine in a theatrical contect, as a matter of how one appears. However, vices may be necessary in order to rule, for it 
is not morals, but necessity that determines a ruler's actions. This is where Machiavelli's Principe becomes revolutionary, according to Quentin Skinner:

It offers, in effect, a new analysis of what should count as virtuoso behaviour in a prince [...] A prince of true virtù will rather be someone who, in the proverbial phrase, makes a virtue of necessity. He will be ready at all times 'to turn and turn about as the winds and variations of fortune dictate'. ${ }^{368}$

In Machiavelli we meet a thinker, then, who considers the political moment as an intense entanglement of activity and passivity, or a simultaneous occurrence of action and being acted upon. Consequently, the political is not a matter of willful actions and strategies, but a ceaseless readiness and drive to act without knowing beforehand what action will be suitable. This does not mean that Machiavelli advocates brutish survival. On the contrary, virtù, with its connotations of skillfulness, counts; it counts as an art and, by implication, aesthetically. In the eyes of Machiavelli, Brutus may have been paradigmatically virtuous, both in his acting like a fool, and in his being able to, in the end, grab the proper moment to revolt against the king. When dealing with Spinoza's idea of affects as intensifying the potency of a body, joyously, or lessening and saddening it, Deleuze states the following:

How does it happen that people who have power, in whatever domain, need to affect us in a sad way? The sad passions are necessary. Inspiring sad passions is necessary for the exercise of power. And Spinoza says, in the Theological-Political Treatise, that this is a profound point of connection between the despot and the priest—-they both need the sadness of their subjects. Here you understand well that he does not take sadness in a vague sense, he takes sadness in the rigorous sense he knew to give it: sadness is the affect insofar as it involves the diminution of my power of acting. ${ }^{369}$

The quote can be read in relation to the build up to political revolution that is captured by Quast's painting. Living under a despot's rule, the people do not act like fools; they become fools, because their powers have been diminished. To be sure, in general, tableaux vivants capture a charged

368 In the original it says: 'E però bisogna che elli abbi uno animo disposto a volgersi secondo ch' e' venti e le variazioni della fortuna li comandono.' See Skinner, Visions of Politics: Regarding Method, p. 147.

369 Gilles Deleuze, 'Deleuze on Spinoza'. 
moment in a well-known history, as this one appears to be doing. Yet, in this context, the tableau vivant - although clearly a form of representation-is in a distinct sense non-representational. In Jean-Pierre Sarrazac's terms (see above), the power of the tableau vivant is retrospective, in that it retraces a history. Yet, it also radiates with the warmth of living bodies, motionless in front of an audience that can almost touch them, and as such these bodies embody a potential. Although the frozen moment of the tableau vivant represents a temporary end in a historical development, it is alive and interruptive in that it upholds what follows. It is truly momentous in this respect-literally breathtaking. Yet it is also momentous and figuratively breathtaking in its attitude towards the future, to which the tableau vivant remains effectively, radically, open. Here, the tableau works like an anticipation, as defined by Sarrazac.

Carrying the weight of a history, embodying the charged relations between live actors, while not showing but already containing the potency of what is to happen, the tableau vivant is particularly intense in terms of affect. With regard to its momentous-ness and openness towards the future, the tableau vivant captures the nature of the political moment. In this context it is not so much retrospective or anticipatory as interruptive, embodying a potential.

\subsection{The political potential in the tableau and the nature of freedom}

In 1659 playwright Joost van den Vondel published Jephta ofte offerbelofte (Jephthah or the vow to sacrifice). The play reworks, expands on, and alters a short passage in the Bible, Judges 11-12:7, in which Jephta appears as the bastard son of Gilead. ${ }^{370}$ After the death of his father, Jephta is disowned by his half-brothers. He leads the life of a robber, until he is called upon by the eldest of his tribe to take up leadership as the judge who gives direction to his lost people. Before a battle with the Ammonites, he promises God that he shall celebrate victory with a sacrifice, namely of the first being he meets coming out the door of his house. This turns out to be his daughter. Even though it is his daughter and despite the ban on human sacrifice, Jephta keeps his word. His daughter is given two months to bid her life farewell. In the meantime,

370 The Dutch Authorized Version of the Bible calls Jephta first 'son of a whore', then the son of 'another woman'. So, probably father Gilead had at least one partner whom he had not married officially; compare Mieke Bal's dealing with the terminology in Death and Dissymmetry. 
Jephta goes to war with a 'brother tribe', the Ephraimites, which he defeats as well. On his return, he kills his daughter, who is called Ifis in the play. ${ }^{371}$

Act I of the play is concerned mainly with getting Ifis' mother out of the house. When this has happened, Ifis and Jephta can take the stage. With them, Acts II, III, and IV concentrate on discussions about the justifications for, and principal injustice of, Jephta's deed. In between Acts IV and VJephta executes Ifis. In Act $V$ he feels remorse and flees, also because Ifis' mother returns. All the while Jephta has certainly had his doubts, but throughout the play he talks of himself as an active, intentional individual. Even when filled with self-disgust at times, he is preparing the murder that, finally, he will carry out with his own hands. Described as such there does not appear to be a truly political, dramatic moment in the play.

Yet, in a performance of the play in the seventeenth century, it became a tableau vivant, designed and described by theater director Jan Vos, who recreated the scene of the crime, down to the clothing and adornments of Ifis, as described in the text..$^{32}$ So we see common periwinkle, the evergreen plant and symbol of virginity, strewn everywhere. Festoons of flowers hang upon all the walls. And we see Ifis kneeling on the sacrificial altar, covered with small branches of wood to catch the blood. She is accompanied by her friends and her virtues: the personifications of Obedience, Innocence, Chastity, and Love. Jephta stands ready with the butchering knife in his right hand and veils his face with the other. It is a gesture based on the famous painting by classical painter Timanthes of the sacrifice of Iphigenia, where he chose to represent father Agamemnon veiling his face. ${ }^{373}$ Then there are the allegorical figures of Religion, who has turned her back on Jephta, and of Nature, who is kept from intervening by the personifications of Jephta's major vices-Religious Fanaticism, Unchangeable Stubbornness, and Uncontrolled Belligerency—while the four daughters of nature (the four

371 In Judges, the daughter has no name. With Abraham de Koning's play from 1615, Iephthah ende zijn eenighe dochters treurspel - Jeptha and his only daughter's tragedy, she did get a name: Miria. In Vondel's play she appears in four acts of the play as Ifis, a name probably taken from George Buchanan's Jephte sive votum, from 1554, who in turn took the name from Ovid's Metamorphoses in which there is a story about a girl Iphis who grows up, disguised as a young man only to change into a real young man (Metamorphoses ix, ll. 666-797). For this, see my Sovereignty as Inviolability. The Ovidian Iphis had to disguise herself as a man because her father had declared to his wife that the child she was bearing had better be a boy: he would kill it if it were a girl. As to the namelessness Biblical character, Bal calls her Bath-meaning 'daughter', see Death and Dissymmetry, p. 43 .

372 Jephta, WB IV, Il. 1236 and following. On this specific tableau, see Mieke B. Smits-Veldt, 'Vertoningen in opvoeringen van Vondels tragedies 1638-1720'.

373 See Mieke B. Smits-Veldt. 'Bredero en Timanthes'. 
elements) show a mix of vehement emotions. In the distance, the figures of Remorse, Dispair, and Frenzy approach, as well as, remarkably, citizens with torches and sabers. ${ }^{374}$

With all the actors thus in place, they freeze for a moment: a temporary end in a development. One can argue that they are just on display, fascinating, and perhaps thrilling an audience that knows what will happen: the sword will come down. However, the inevitability of this, or the closed-ness of this history, is countered by the chorus at the end of Act IV. It describes a well-known history, the one of Abraham and Isaac, that on the level of action freezes into a tableau vivant as follows:

See them there, together.

The altar stands built.

Isaac, the blessing of his father,

Kneels on the sacrificial wood.

5 Abraham draws the sword

To hit, when he

By the Angel with his voice

From heaven is stopped. 375

The crucial sentence is vs. 1664 , here line 6: 'to hit, when he'. It is a verse that breaks off, leaving a blank. Abraham, in his prefiguring of Jephta, was about to hit when he... did what? Did he, or didn't he? This is the moment in time where history may be swerved from what seemed to be destined. Suddenly a warmth of possibilities can be felt. Someone may act differently than we had expected, not out of his own free will but in a situation of simultaneous acting and being acted upon. In the play this is a dramatic moment and a matter of what Sarrazac called optation-'Wish that Jephta had not done what he did'. Yet it is also a moment of veritable interruption captured in the question: 'Is he going to, now, or is he not?'376

It is such a moment that is caught in Vos' tableau vivant. Whereas earlier I stated that both the tableau vivant and the political moment are not about representation, one could argue that here we have a set of distinctive

374 Vos, Alle de gedichten. I, p. 608.

375 Vondel, Jephta, WB IV, ll. 1658-1666; emphasis mine. In the original: 'Zietze bey te gader. / 't Outer staet gebout. / Isack, 's vaders zegen, / Knielt op 't offerhout. / Abram treckt den degen / Om te slaen, als hem / d'Engel met zijn stem / Uit den hemel tegenhiel.'

376 In fact, the 'what-if' was explored in the previously mentioned play from 1615 by Abraham de Koning entitled Jeptha and his only daughter's tragedy; see Lia van Gemert, 'The Politics of Visuality in Dutch Renaissance Tragedy'. 
representative personifications or allegorical figures, such as Religion and Nature. It is indeed so, but the nature of their representing something is one thing. The other is their frozen action. Religion, for instance, has turned away, or rather, is being turned away. This turning away of Religion is intrinsically political in relation to the future; it shows that what is about to happen will not be sanctified. Besides, as for what is about to happen, the impossible question remains: will it? We seem to know. Yet the moment that is being captured is the one 'just before.' Intensifying that moment, the scene becomes breathtaking, momentous, in that there is still the possibility that it will not happen. Jephta can decide, driven by whatever affect, not to kill his daughter. All this can be felt by a live audience, sensing the vigor of the bodies capturing the moment. Both actors and audience are in this breathtaking moment. Once the actors disentangle, get out of their pose, the moment will be gone. Something momentous will have taken place. The daughter is dead, or she lives. The son is dead, or he lives. The father killed his child, or not.

The tableau effectively manages to interrupt time. This results in an affectively heightened moment of awareness, or an intensified connection between audience and subject in relation to time. This intensity cannot be explained by considering the frozen moment only in relation to a wellknown or pre-ordained history. Partly, the intensity is dependent upon a well-known history and as such it is a repetition. Yet, it is also related to an unknown future and is, in this way, a repetition with a difference. Even when this future is known, the tableau vivant may destabilize it and point to the possibility that it is not known. The frozen moment or tableau vivant is an in-between, a medium that, as such, forms an excellent carrier of affect. Aesthetically, in terms of affect, the tableau vivant helps to connect us with a distinctive historical moment in a particularly intense way.

I read Vondel's intertextual play with the story of Abraham and Isaac, and the visual tableau vivant by Vos on Ifis and Jephta, as embodiments of a positive reconceptualization of affects in the seventeenth century. This is not to say that Vondel or Vos endorsed the flourishing materialist philosophy that was allowed to develop in the Dutch Republic. Their art though, seems to have absorbed what was discussed publicly and privately. And one of the most radical contributors to that discussion was Spinoza, who defined affectus as the continuous variation of the power of acting. ${ }^{377}$ With 'power', politics is implied, and with 'variation', or intensity, aesthetics. Indeed, affect is intrinsically related to both; it works on the crossroads between politics 
and aesthetics. This ties in with how Spinoza defines affectio, in the analysis of Deleuze, as 'a mixture of two bodies, one body which is said to act on another, and the other receives the trace of the first. ${ }^{37^{8}}$ That is, affects are about the intensity and power of relations.

Now, Spinoza was only one of several thinkers who would change European thinking on affects and the way in which human beings act in the world. ${ }^{379}$ Before Spinoza, for instance, Franco Burgersdijk (1590-1635) had been teaching philosophy at Leiden University from the 1620 onward and he considered affects 'not as the dark side of man, as flesh opposed to spirit, but as the material upon which man can develop his potentialities' as Hans Blom paraphrases. ${ }^{80}$ Considered within the frame of potency, the nature of the political subject would start to change. Coincidentally, the conceptualization of freedom would be subject to change as well. It no longer needed to be defined by individual will and volition, but could be determined by affect, drive, relation, and choice.

Looking for an image that may illustrate how the political ultimately is an act of a kind of freedom, Fabio Vighi and Heiko Feldner, authors of Žižek beyond Foucault, give the example of what, according to some, is one of the best goals in the history of soccer: not the infamous 'Hand of God' goal, but the second goal of Diego Maradona at the World Championship of 1986, Argentina against England. To understand what Vighi and Feldner mean, keep in mind Žižek's conceptualization of freedom:

Freedom is not the freedom to do as you like (that is to follow your inclinations without any externally imposed constraints), but to do what you do not want to do, to thwart the 'spontaneous' realization of an impetus..$^{81}$

In the first line of this quote, Isaiah Berlin's two classical conceptualizations of freedom are condensed: positive freedom, indicating that you are enabled to act freely according to your will, and negative freedom, indicating that there are no forces outside of you that hinder or restrict your actions..$^{82}$

378 Deleuze, 'Deleuze on Spinoza'.

379 For the more general context see the two studies by Jonathan Israel, Radical Enlightenment and Enlightenment Contested. The complex intertwinement of enlightenment and religion is central to Eric Jorink, “Outside God, there is Nothing”: Swammerdam, Spinoza and the Janus-Face of the Early Dutch Enlightenment'.

380 Hans W. Blom, 'Morality and Causality in Politics', p. 77.

381 Slavoj Žižek, The Parallax View, p. 202.

382 Berlin's inaugural lecture from 1958, 'Two Concepts of Liberty,' has been republished in Liberty: Incorporating Four Essays on Liberty, pp. 166-217. 
Žižek's conceptualization ignores the antithesis between the two because both ideas of freedom concern a (political) subject who is, as an autonomous, conscious actor, able to make politics, or history. For Žižek, in the context of the power of capitalism, political freedom cannot be considered in terms of such conscious and willful actions, but only in relation to a drive. Such a drive is not free in itself, but without it the opening up of a new possibility is impossible. That opening up cannot be a matter of strategy either, for then we are talking about politics in terms of achievable goals, and the very idea of achievability implies a form of historical closed-ness.

With respect to all this, Maradona's action is an example of what it might mean to grab the political moment, driven by something, and opening up history. Attacked by one English player at his back and by one at a slight angle to the right and ahead of him, while a third player blocks an escape to the left, Maradona's rational option is to pass the ball to one of his teammates in front of him. But instead the inconceivable happens, through what Vighi and Feldner call 'an impromptu pirouette' - an act of virtuosity. ${ }^{3{ }^{83}}$ Read through a Spinozean lense, this is not a moment of intuition only, but also a paradigm of a body's ability to act. If we freeze the moment just before this act we have an image that resembles a tableau vivant. Those who know what it represents recognize the temporary end, and are aware of what will happen. So, how can the scene still work? Like this: it is as if we can sense the radical openness of history, and perhaps more fully now than at the moment itself, in 1986.

Five related issues can be derived from this scene. One: freedom consists in an entanglement of bodies acting and being acted upon. This entanglement remains dramatically open, or can be opened up, through a drive. Maradona produces freedom through his pirouette. He does not have it in the sense of a free will that determines his actions beforehand, nor is he free from opposing forces. Acting, and simultaneously being the object of others' actions, he operates freely, suddenly. Two: the nature of the political moment is such that we do not know beforehand what an actor is going to do. Only with hindsight, the course of history will appear to have been changed. Yet, and this makes three: the political moment is momentous, even on the slightest time-scale, and both in micro-politics and macro-politics. Whereas with the tableau vivant we take time, freezing the movement as if we hold our breaths, there is something in the political moment as well, perhaps in a split second, that has this breathtaking quality. Four: in relation to both freedom-in-acting and the political moment, affects play a pivotal role. 
Driven by affects, affecting others and affected by others, caught in an intensified moment, subjects act. However, five: the moment at which an act becomes decisively political, it gets charged aesthetically, as a result of which it can be judged in hindsight both politically and aesthetically as a theatrical event.

If the above may seem abstract, let me make it particular again by returning to what was central to chapter 3 : to Johan de Witt and his major political opponent, William III.

\subsection{Moment of closure: spectacle and a revolting tableau}

If the Dutch baroque had its moment of closure on a specific date, 20 August 1672 , I also argue that this moment was prepared on 17 June 166o. At the time Amsterdam would have loved to host the English king Charles II. Yet the latter had only just become king after the defeat of Cromwell; he was fully in charge only since 29 May. His restoration as king ended a charged, secret agreement between the Dutch Republic and the Cromwellian Commonwealth: the so-called Acte van Seclusie (Act of Seclusion, 1654). Through it the Dutch Republic had promised the Commonwealth that William III would never acquire stadholdership of Holland or of any of the other provinces. The reason was that William was a descendant of the House of Stuart — son of Mary Henrietta Stuart_-and, as such, a potential threat to the Commonwealth should he aspire to be English king.

Whether it was Cromwell who demanded this Act of Seclusion or whether Grand Pensionary Johan de Witt suggested it, is still an issue of debate. In 166o, William III, who was not more than ten years old at the time, was the object of fierce internal and international political deliberations that to us may seem to be no more than quibbling about his future task, namely whether he would or should be raised to become 'kapitein-generaal' (captain-general). It was a 'designation' that was much desired by his mother, who, to that end, had used her influence in the previous years and months. If the prince, who seemed to be neutralized as a political force, stood a chance of being 'designated' as future kapitein-generaal, this at least suggested that he would be supreme commander to the army. Johan de Witt, in 1667, would try to pass the Eeuwige Edict ('Eternal Edict') to prevent just that. There was reason enough, then, for Charles to send the young William and his mother to Amsterdam to get a sense of, and influence, the political atmosphere. The company, consisting of no less than 125 participants, arrived in Amsterdam 
on June 15. In the coming days it would be honored with festivities including a show of tableaux vivants, designed by Jan Vos.

Vos presented a series of tableaux vivants, some new and some re-used, that allegorically presented several key players in recent historical developments. ${ }^{34} \mathrm{He}$ re-used carriages or floats that he had designed for the reception of Amalia van Solms, grandmother of William III, in August 1659, but also designed and added others. The Dutch Provinces were each allegorically represented, as were the Netherlands as a whole, the three kingdoms of Scotland, Wales, and England, and finally the city of Amsterdam, as well as Justice, Gratitude, and Unity. But several of the carriages were not at all allegorical. Some showed ancestors of the young prince William-both the ancestry of the house of Nassau and Orange, and the ancestry of the house of Stuart. Others showed some key moments in recent English history, and one of them specifically depicted the beheading of Mary Henrietta's father, Charles I. As Jochen Becker stated, it was especially this carriage 'at which his daughter was greatly moved' ${ }^{385}$ This is putting it mildly: she turned her head in revulsion. ${ }^{366}$ The consequences for Vos were considerable. He became the object of a national debate with poems and pamphlets flying to and fro. Perhaps more tellingly, the carriages and floats that had been used to stage the tableaux were all stored and then destroyed.

What interests me most in these events is the fact that this specific tableau generated such an emotional reaction from the princess. She must have been accustomed to the numerous depictions of and texts about her father's beheading, which had taken place eleven years earlier. Then, the question is why it led to such an enormous collective commotion. In relation to both, and in the context of my argument, the event also involves a distinction to be made between spectacle and theater. Spectacle is at times confused with theatricality. This is the case, for instance, when Bart Verschaffel defines theatricality in relation to the sovereign viewpoint of the king or the pope, and considers it predominantly a matter of architecture, a means to orchestrate vision and perspective ${ }^{387}$ In the reorganization of fifteenthcentury Rome specifically, Verschaffel sees a grandiose reorganization of the city as a papal theater with imperial overtones that glorified the city

384 For the entire procession, see Jochen Becker, 'The Princess of Orange's Welcome into Amsterdam in 166o'.

385 Jochen Becker, 'The Princess of Orange's Welcome into Amsterdam in 166o', p. 576.

386 On this see Willem Frijhoff, \& Marijke Spies, Dutch Culture in a European Perspective, pp. 440-441. On Jan Vos in general, see Nina Geerdink, Dichters en verdiensten. On the commotion after Vos' mistake, see Rudolf Cordes, Jan Zoet, Amsterdammer 16o9-1674, pp. 436-440. 387 Bart Verschaffel, 'Rome: Over theatraliteit'. 
(Rome) while at the same time glorifying the world — a world that fell under the rule of a city ruled by a quasi-imperial power.

In the context of the papal, Roman Catholic exercise of power, Verschaffel then comes to considers theatricality as a dignification of the spectacular, because he considers the Greek theatron to have meant 'what is worthy to be seen'. This is his contention:

To theatricalize is not to perform a fiction, but to decide on the point from which something has to be seen, and to change a spectacle into a show that can be seen in a perfect way. The theater transforms and dignifies both the seeing and the spectacle..$^{88}$

In his isolating the verb 'to theatricalize' for its dignifying potential, and almost as a consequence linking it solely to dignitaries, Verschaffel is only able to analyze a very limited set of theatrical, artistic, or social phenomena. Worse, in falling back on the Greek origin of 'what is worth to be seen', he is dignifying things in the wrong way. What was worth to be seen in classical Greece were also farces and comedies that often verged on the obscene, as when the dignitaries in the theater were ruthlessly mocked, for instance in the farces of Aristophanes. Lastly, the origin of theater is neither royal, nor imperial, nor papal, for that matter. Theater is a distinctly urban institution that differs principally, also in terms of architecture, from the imperial or royal circus. Here, I would like to preserve spectacle in the light of its historical origin, which connects it to the Roman Games, games that cannot be thought of without the architectonic model of the circus, or without this model's connection to the display of imperial power. In the case of the spectacle, the idea is not that an audience comes to simply look, but to take a side. Moreover, also due to its historical origin, there is always a matter of scale in play; spectacles tend to be 'big'.

The show provided by Vos for the English queen was a spectacle that was both urban and royal. With respect to this, Stijn Bussels argues that the pamphlets following Vos' procession showed how people collectively 'debated the use and appropriateness of such an overwhelming effect for political purposes. Here too, the choice between the explicit staging or the suggestion of cruelties formed a central point of the debate. ${ }^{389}$ The debates that Bussels hints at indeed concerned the display of cruelty. Yet, in this

388 Bart Verschaffel, 'Rome: Over theatraliteit', p. 22. My translation FWK.

389 See: http://www.hum.leiden.edu/lucas/elevatedminds/about-the-projects/about-theprojects.html. Historically the controversy concerned Vos' public figure. Putting himself on 
case I would argue that the debates following the incident focused more on the figure of Jan Vos, who had disproportionally staged himself as part of the spectacle, leading it on horseback as if he were royal himself. And if this tableau was 'overwhelming', it was not because of a sublime quality but a shockingly straightforward realism. Despite the spectacle, the tableau had yet again demonstrated its remarkable formal potential to theatrically show an event that, as such, was 'dead' while also presenting for real, in the shape of living bodies, a dramatic moment of actualization. In a sense, Mary Stuart's turning of her head in revulsion was a bodily expression of the fact that history should have had another bifurcation before the moment of the beheading. The tableau, in this context, was both a theatrical representation and something that was so 'real', dramatically, that it made the spectacle fail.

The fact that the floats were destroyed after this spectacular failure may be a coincidence, or an anecdote. It may also be a telling sign. In her study into the Amsterdam labyrinths, Marijke Spies describes how innkeeper Vincent Jacobsz Coster established a labyrinth in his own garden shortly before 1625. A neighboring inn called 'The Orange Pot' did the same thing a little later. ${ }^{390}$ The first one had close ties with the Amsterdam theater and with Jan Vos. It often had tableaux consisting of statues, often statues that could move, as if to form a mechanic counterpart to the tableau vivant. These arrangements did not have explicit symbolic or moral lessons. Yet, the exuberant, at times unchaste, farcical, and comical shows, full of affects and emotions, were to change in tone and atmosphere three decades later. As Spies notes:

Pathos belonged to the elite culture of those visiting the theater. But among the bourgeois middle classes, a religiously defined-Calvinist, Lutheran, or Roman Catholic-dullness and neatness had definitely established itself. The growing religious content in the second half of the century, partly in the Old, but especially in the New Labyrinth, signals a changed cultural interest. Even in the garden of statues, the Republic started to become 'decent'. ${ }^{391}$

horseback at the front of the procession was perhaps both a little too theatrical and a little too dramatic at once.

390 The first came to be called the Old Labyrinth, the second the New Labyrinth, see Marijke Spies, 'Amsterdamse doolhoven', p. 71.

391 Marijke Spies, 'Amsterdamse doolhoven', p. 78. In the original: 'Pathos hoorde bij de elitecultuur van degenen die de schouwburg bezochten. Maar bij de burgerlijke middengroepen had zich rond 1660 definitief een religieus - calvinistisch, luthers of rooms - ingevulde saaiheid en keurigheid gevestigd. Ook het in de tweede helft van de eeuw toenemende religieuze gehalte, 
Spies' assessment is shared by René van Stipriaan, who contends that at the end of the seventeenth century the 'culture of frivolous ambiguities was taken in the stranglehold of moral seriousness. ${ }^{392}$ To be sure, if the Dutch baroque's moment of decline is 20 August 1672 , this is not its definitive and final end. Rumphius had another thirty years to live, Spinoza five. Vondel still had seven years left, although his last work had been published in 1668. Yet, Focquenbroch was dead already, as were Rembrandt, Hals, and Vos. The power of the Dutch republican baroque had started to wane. So, let me suggest that, perhaps, on 17 June 1660 the Dutch baroque oyster began to close itself down and that after the death of the brothers De Witt its closure speeded up. It was to leave the world its pearl, a bloody pearl at that, and not just because of the way in which the brothers were slaughtered. In fact, the Dutch republican baroque, as a republican one, had already been corroded or calcified into a painful foreclosure with the advent of slavery.

enigszins in de Oude, maar vooral in de Nieuwe Doolhof, wijst op een veranderde culturele belangstelling. De Republiek begon "fatsoenlijk" te worden en dat tot in de beeldentuin toe.' 392 René van Stipriaan, Lof der botheid, p. 188. 
This content downloaded from 132.229.156.144 on Tue, 05 Feb 2019 10:43:04 UTC All use subject to https://about.jstor.org/terms 


\section{List of illustrations}

Fig. 1: Carel Fabritius, $A$ young man in a fur cap, 1654, oil on canvas, $70.5 \times 61.5 \mathrm{~cm}$, The National Gallery, London, Accession Number: $\mathrm{NG}_{4042}$

Fig. 2: $\quad$ Cornelis Brisé, Documents concerning the treasury of the city of Amsterdam, 1655, oil on wood, $192 \times 147 \mathrm{~cm}$, Royal Palace, Amsterdam, Accession Number: SA3034. Original: 'Documenten betreffende de Thesaurie van de Stad Amsterdam'

Fig. 3: $\quad$ Egbert van der Poel, A view of Delft after the explosion of 1654,1654 , oil on oak, $36.2 \times 49.5 \mathrm{~cm}$, The National Gallery, London, Accession Number: NG1061

Fig. 4: $\quad$ Egbert van der Poel, $A$ view of Delft with the explosion of 1654,1654 , oil on panel, $36 \times 49 \mathrm{~cm}$, Rijksmuseum, Amsterdam, Accession Number: SK-A-309,2

Fig. 5: Nicolaus Knüpfer, Scene from the marriage between Messalina and Gaius Silius, possibly an episode from a play, c. $1645^{-1655}$, oil on panel, $60 \times 74.5 \mathrm{~cm}$, Rijksmuseum, Amsterdam, Accession Number: SKA4779. Original: 'Scène uit het huwelijk van Messalina en Gaius Silius, mogelijk episode uit een toneelstuk'

Fig. 6: $\quad$ Lieve Verschuier, The keelhauling of the surgeon of admiral Jan van Nes, 1660-1686, oil on canvas, $106 \times 159$ cm, Rijksmuseum Amsterdam, Accession Number: SKA449. Original: 'Het kielhalen van de scheepschirurgijn van admiraal Jan van Nes'

Fig. 7: $\quad$ Detail of The execution of the surgeon on the ship ofJ. van Nes

Fig. 8: $\quad$ Jan de Baen, The corpses of the brothers De Witt, 1672, c. 1672-1675, oil on canvas, $69.5 \times 56 \mathrm{~cm}$, Rijksmuseum, Amsterdam, Accession Number: SKA15

Fig. 9: $\quad$ Frans Hals, Young man and woman in an inn, 1623, oil on canvas, $105.4 \times 79.4 \mathrm{~cm}$, Metropolitan Museum, New York, Accession Number: 14.40.6o2 (artwork in the public domain)

Fig. 10: Jan Steen, Gamblers quarreling, 1665, oil on canvas, $70.5 \times 88.3 \mathrm{~cm}$, Institute of Arts, Detroit, Accession Number: 89.46, (artwork in the public domain) 
Fig. 11: Frans Hals, Laughing fisherboy, c. 1627-1630, oil on canvas, $82 \times 60.2 \mathrm{~cm}$, Schloss Burgsteinfurt, (Private collection Prince zu Bentheim und Steinfurt, Burgsteinfurt, Westphalia)

Fig. 12: $\quad$ Frans Hals, Young man with skull (Vanitas), c. 1626-1628, oil on canvas, $92.2 \times 80.8 \mathrm{~cm}$, National Gallery, London, Accession Number: NG6458 (artwork in the public domain)

Fig. 13: $\quad$ Frans Hals, The jolly reveller, or Peeckelhaering, 16281640, oil on canvas, $75 \times 61.5 \mathrm{~cm}$, Gemälde Galerie Alte Meister, Kassel, Accession Number: GK216 (artwork in the public domain)

Fig. 14: Frans Hals, The mulatto, c. 1628-1630, oil on canvas, $75.5 \times 63.5 \mathrm{~cm}$, Museum der Bildende Kunst, Leipzig, (artwork in the public domain)

Fig. 15: Old photo of the painting Portrait of Pieter Verdonck when it was still known as Man with a wine glass, before \& after photos published in an article in the Sumatra Post in 1928 (Koninklijke Bibliotheek, record number: $1634 \mathrm{C} 1$ )

Fig. 16: $\quad$ Frans Hals, Verdonck, or Portrait of a man with a cow's jawbone in his hand, bout 1627, oil on panel, $46.70 \times 35.50 \mathrm{~cm}$, National Gallery, Scotland, Accession Number: NG 1200, (artwork in the public domain)

Fig. 17: $\quad$ Pieter de Wit, Portrait of Dirck Wilre in the castle of St. George d'Elmina, 1669, $103.2 \times 141.4 \mathrm{~cm}$, oil on canvas, auctioned in 1994 Sotheby's. London, Identifier: AKG 354866

Fig. 18: $\quad$ Hugo Ruys, Expansion plan of Hendrick Moreelse or 't Concept vande plat grondighe afbeeldingh des oude en niwe stad Utrecht, 1664, etching, $50.8 \times 68.9 \mathrm{~cm}$, Centraal Museum, Utrecht, Accession Number: 1030/002

Fig. 19: Depiction of the city - with its most recent expansion, by Daniël Stalpaert, 1665, drawing, Collectie Atlas Kok, Stadsarchief Amsterdam, Accession Number: 10095/76

Fig. 20: $\quad$ Rembrandt van Rijn, Father Abraham playing with his son, or Abraham caresses Isaac (aka Jacob caresses Benjamin), $1635^{-1639,11.6 \times 8.9 ~ c m, ~ e t c h i n g ~ o n ~ p a p e r, ~}$ Rijksmuseum, Amsterdam, Accession Number: RPPoB6o 
Fig. 21: Rembrandt van Rijn, Joseph telling his dreams to Jacob, c. $1642-1643,17.5 \times 24.5 \mathrm{~cm}$, pen and bistre heightened with white, Albertina, Vienna, Accession Number: 8772

Fig. 22: Detail of hand and button, Rembrandt van Rijn, Father Abraham playing with his son

Fig. 23: Rembrandt van Rijn, The angel preventing Abraham from sacrificing his son Isaac, c. 1634-1635, 19.5 × 14.7 $\mathrm{cm}$, chalk on paper, The British Museum, London, Accession Number: 1897,1117.5

Fig. 24: Pieter Quast, The triumph of Folly: Brutus in the figure of a fool before king Tarquinius, 1643, $69 \times 99.2 \mathrm{~cm}$, oil on panel, Mauritshuis, The Hague, Accession Number: 447 
This content downloaded from 132.229.156.144 on Tue, 05 Feb 2019 10:43:05 UTC All use subject to https://about.jstor.org/terms 


\section{Bibliography}

Aa, A.J.van der, Biographisch woordenboekder Nederlanden. Deel 2. Haarlem:JJ van Brederode, 1855. Ahmed, Sara. The Promise of Happiness. Durham \& London: Duke University Press, 2010.

Albach, B. 'De schouwburg van Jacob van Campen'. Oud Holland, 85 (1970): pp. 85-109.

Albach, B. 'Drie eeuwen Gysbreght van Aemstel.' In Kroniek van de jaarlijkse opvoeringen. Amsterdam: N.V. Noord-Hollandsche Uitgeversmaatschappij, 1937.

Albach, Ben. 'Pekelharing: Personage en Potsenmaker'. Literatuur 17 (1990): pp. 74-8o.

Alpers, Svetlana. The Art of Describing: Dutch Art in the Seventeenth Century. Chicago: University of Chicago Press, 1983.

Alphen, Ernst van. 'Affective Operations of Art and Literature'. Anthropology and Aesthetics, 53/54 (2008): pp. 21-30.

Althusser, Louis. 'Contradiction and Overdetermination'. In For Marx. Translated by B. Brewster, pp. 87-127. Harmondsworth: Penguin Books, 1969.

Althusser, Louis. Machiavelli and Us. London: Verso, 2010.

Althusser, Louis. 'On Brecht and Marx'. Translated by M. Statkiewicz. In W. Montag, Louis Althusser, pp.136-149. London and New York: Palgrave-Macmillan, 2003.

Althusser, Louis. 'The Object of Capital'. Translated by B. Brewster. In L. Althusser and E. Balibar. Reading Capital, pp. 71-198. London; New Left Books, 1970.

Anonymous. 'De verhemelde geest van den doorluchtigen Oranje-martelaer Henry de Fleury', 1672. http://www.dbnl.org/tekst/_vero15verho1_01/_vero15verho1_01_0002.php

Arasse, Daniel. Anachroniques. Paris: Gallimard, 2006.

Arendt, Hannah. The Human Condition. London/Chicago: University of Chicago Press, 1989 [1958].

Arendt, Hannah. 'The Great Tradition II: Ruling and Being Ruled' Social Research 74, no. 4 (2007): pp. 941-954.

Arendt, Hannah. The Promise of Politics. Edited and introduced by J. Kohn. New York: Schocken Books, 2005 .

Aristotle, Poetics. Translated by Malcolm Heath. London: Penguin Classics, 1996.

Arnade, Peter. Realms of Ritual: Burgundian Ceremony and Civic Life in late Medieval Ghent. New York: Cornell University, 1996.

Astell, Ann W. Political Allegory in Late Medieval England. Ithaca: Cornell University Press, 1999.

'Astronomical observations'. Vatican Museums. http://mv.vatican.va/3_EN/pages/x-Schede/ PINs/PINs_Sala15_08_059.html

Atkins, Christopher D.M. The Signature Style of Frans Hals: Painting, Subjectivity and the Market in Early Modernity. Amsterdam: Amsterdam University Press, 2012.

Attridge, Derek.J.M. Coetzee and the Ethics of Reading: Literature in the Event, Chicago: Chicago University Press, 2004.

Augustine. City of God. Translated by Henry Bettenson. London: Penguin Classics, 2003.

Baay, Reggie. Daar werd wat gruwelijks verricht. Amsterdam: Singel Uitgeverijen, 2015

Badiou, Alain. Rhapsody for the Theatre. London: Verso, 2013.

Badiou, Alain. L'être et l'événement. Paris: Seuil, 1988.

Badiou, Alain. The Logic of Worlds: Being and Event II. Translated by Alberto Toscano. London: Bloomsbury Academic, 2008.

Bainton, Ronald H. Michel Servet: hérétique et martyr (1553-1953). Genève: Droz, 1953.

Bakker, Boudewijn. Amsterdam en de grachtengordel. Amsterdam: Thoth, 2009.

Bal, Mieke, Death and Dissymmetry: The Politics of Coherence in the Book of Judges. Chicago: University of Chicago Press, 1988. 
Bal, Mieke, Travelling Concepts in the Humanities: A Rough Guide. Toronto: Toronto University Press, 2002.

Bal, Mieke. Narratology, Toronto: University of Toronto Press, 1997.

Bal, Mieke. Quoting Caravaggio: Contemporary Art, Preposterous History. Chicago: Chicago University Press, 1999.

Banfield, Ann. The Phantom Table: Woolf, Fry, Russell, and Epistemology of Modernism. Cambridge: Cambridge University Press, 2000.

Bar, Ludwig von. A History of Continental Criminal Law. Boston: Little, Brown and Company, 1916. https://archive.org/details/historyofcontineoobarl

Baraz, Daniel. Medieval Cruelty: Changing Perceptions, Late Antiquity to Early Modern Period. Ithaca: Cornell University Press, 2003.

Barend-Van Haeften, Marijke and Arie Jan Gelderblom, 'Inleiding', in Buyten gaets. Twee burleske reisbrieven van Aernout van Overbeke. Hilversum: Verloren, 1998.

Becker, Jochen. 'The Princess of Orange's Welcome into Amsterdam in 166o'. In J.L. Mulryne et al., Europa Triumphans: Court and Civic Festivals in Early Modern Europe Vol. 1, pp. 575-583. London: Ashgate, 2014.

Beekman, E.M. The crippled heart: An introduction to the life, times and works of Willem Godschalk van Focquenbroch, Leiden: Astrea, 1997.

Beekman, E.M. 'Introduction: Rumphius' Life and Work'. In G.E. Rumphius. The Ambonese Curiosity Cabinet. Edited and translated by E.M. Beekman, pp. xxxv-cxii. New Haven, CT [etc.]: Yale University Press, 1999.

Benjamin, Walter, Selected Writings 1935-1938. Translated by Edmund Jephcott, Howard Eiland et al., edited by Howard Eiland and Michael W. Jennings. Cambridge, MA: Harvard University Press, 2002.

Benjamin, Walter. 'What is Epic Theatre?' in Understanding Brecht. London: Verso, 2003.

Benjamin, Walter. The Origin of German Tragic Drama. Introduced by George Steiner, translated by John Osborne. London/New York: Verso, 2003.

Bennett, Jim, Michael Cooper, Michael Hunter, and Lisa Jardine. London's Leonardo: The Life and work of Robert Hooke. Oxford: Oxford University Press, 2003.

Benoist, Alain de. 'What is Sovereignty', Telos, 116 (Summer 1999): pp. 99-118, http://journal. telospress.com/content/1999/116/99.full.pdf+html

Bergson, Henri. The Creative Mind: An Introduction to Metaphysics. Mineola, NY: Dover Pulications, 2013.

Berlant, Lauren. Cruel Optimism. Durham: Duke University Press, 2011.

Berlin, Isaiah. Liberty: Incorporating Four Essays on Liberty. Edited by Henry Hardy. Oxford: Oxford University Press, 2002.

Bie, Jan Pieter de, en Jakob Loosjes, Biographisch woordenboekvan protestantsche godgeleerden in Nederland. Deel 3. 's-Gravenhage: Martinus Nijhoff, 1919-1931.

Binder, Franz and Nornert Scheeloch, 'Dirck Dircksz Wilre and Willem Godschalk van Focquenbrogh (?) painted by Pieter de Wit at Elmina in 1669', Bulletin van het Rijksmuseum 27 , no. 1 (1979): pp.7-25.

Bindman, David and Henry Louis Gates jr. The Image of the Black in Western Art, Volume III: From the "Age of Discovery" to the Age of Abolition, Part 1: Artists of the Renaissance and Baroque. Cambridge: Harvard University Press, 2010.

Blackburn, Robin. The Making of New World Slavery: From the Baroque to the Modern $1492-1800$. London: Verso, 1998.

Bleeker, Maaike. Visuality in the Theatre: The Locus of Looking. Basingstoke: Palgrave Macmillan, 2008. 
Bleeker, Maaike.'Being Angela Merkel.' In E. van Alphen, M. Bal and C. Smith, eds. The Rhetoric of Sincerity, pp. 247-262. Stanford: Stanford University Press, 2009.

Blockmans, Wim and Walter Prevenier. The Burgundian Netherlands. Cambridge: Cambridge University Press, 1986.

Blom, Hans W. 'Morality and Causality in Politics: The Rise of Materialism in Dutch 17th century Political Thought'. PhD diss., University of Utrecht, 1995.

Bloom, Harold, Neil Heims and Heather Dubnick, eds. William Blake. New York: Chelsea House Publishers, 2005.

Blumenberg, Hans. Die Legitimität der Neuzeit. Frankfurt am Main: Suhrkamp, 1988.

Bobbit, Philip. The Shield of Achilles: War, Peace, and the Course of History. New York: Alfred A. Knopf, 2002.

Bodin, Jean. The Six Bookes of a Commonweal. Translated by Richard Knolles. Edited by Kenneth Douglas McRae. Cambridge: Harvard University Press, 1962.

Bohn, Babette, and James M. Saslow, A Companion to Renaissance and Baroque Art. Chichester: John Wiley, 2013.

Bono, James J. The Word of God and the Languages of Man: Interpreting Nature in Early Modern Science and Medicine. Vol. 1, Ficino to Descartes. Science and Literature. Madison: University of Wisconsin Press, 1995 .

Borch, Olaus, Itinerarium 1660-1665: The Journal of the Danish Polyhistor Ole Borch. Edited by H.D. Schepelern, 4 vols. Copenhagen: The Danish Society of Language and Literature, 1983.

Boyajian, James C. Portuguese Trade in Asia Under the Habsburgs, 1580-1640. Baltimore/London: Johns Hopkins University Press, 1993.

Bostoen, Karel. 'Opgewekte berichten uit het droevig Morenland: Afrika en de Afrikanen in de Afrikaense-Brieven (1668-1670) van Focquenbroch'. Fumus, 5 (2007): pp. 1-28.

Braake, S. Ter. Manifest van de ware vrijheid: de deductie van Johan de Witt uit 1654 . Arnhem: Sonsbeek Publishers, 2009.

Braekman, Willy L. 'The relationship of Shakespeare's Titus Andronicus to the German play of 1620 and to Jan Vos's play Aran en Titus'. Studia Germanica Gandensia, 10 (1968): pp. 7-77.

Braider, Christopher. Baroque Self-Invention and Historical Truth: Hercules at the Crossroads. London: Ashgate, 2004.

Brandt, Geeraardt. Het leven van Joost van den Vondel. In: J.V. Vondels Poëzy of Verscheide Gedichten. Op een nieu by een vergadert, en met veele ook voorheen nooit gedrukte dichten vermeerdert: Mitsgaders een aanleidinge ter Nederduitsche Dichtkunste, en het Leven des Dichters. Franeker: Leonard Strik, 1682.

Brecht, Bertolt. Brecht on Theatre: The Development of an Aesthetic. Edited and Translated by John Willett. London: Methuen, 1964.

Brecht, Bertolt. Versuche 1-3. Berlin: Gustav Kiepenheuer Verlag, 1930.

Breen, Keith. 'Law beyond Command?: An Evaluation of Arendt's Understanding of Law'. In Marco Goldoni and Christopher McCorkindale, eds. Hannah Arendt and the Law, pp. 15-34. Oxford and Portland: Hart Publishing, 2012.

Brom, Gerard. Vondels geloof. Amsterdam: Spiegel, 1935.

Brooks, Douglas A., Ton Hoenselaars and Holger Klein, eds. Shakespeare and the Low Countries. New York: Edwin Mellen, 2005.

Bryant, Levi R. Difference and Given-ness: Deleuze's TranscendentalEmpricism and the Ontology of Immanence. Evanston, IL: Northwestern University Press, 2008.

Bryson, Norman. Looking at the Overlooked: Four Essays on Still Life Painting. London: Reaktion Books, 1990. 
Buchanan, George. Tragedies. Edited by Peter Sharratt and P. G. Walsh. Edinburgh: Scottish Academic Press, 1982.

Buci-Glucksmann, Christine. La folie du voir: de l'esthétique baroque. Paris: Galileé, 1986.

Buci-Glucksmann, Christine. Le baroque littéraire: theorie et pratiques. Paris: Fondation Calouste Gulberkian, 1990.

Buci-Glucksmann, Christine, ed. Puissance de Baroque: les forces, les formes, les rationalités. Paris: Galilée, 1996.

Bussels, Stijn. 'Performing the Sublime. Theatre \& Politics in Seventeenth-Century Amsterdam', http://www.hum.leiden.edu/lucas/elevatedminds/about-the-projects/about-the-projects.html

Caenegem, R.C. van. An Historical Introduction to Western Constitutional Law. Cambridge: Cambridge University Press, 1995.

Camerata Trajectina, Bavianen en Slijkgeuzen: Liederen van Remonstranten en Contra-Remonstranten uit het begin van de 17 de eeuw (Globe 6031, 1995)

Cammen, Hans van der, and Len de Klerk. Ruimtelijke ordening:van grachtengordel tot vinexwijk. Utrecht: Spectrum, 2006.

Carl, Klaus H., and Victoria Charles. Baroque Art. New York: Parkstone International, 2009.

Carlson, Marvin. Theories of the Theatre: A Historical and Critical Survey from the Greeks to the Present. Ithaca, NY: Cornell University Press, 1984.

Cavazza, M. 'The Institute of Science of Bologna and the Royal Society in the eighteenth century'. In Notes \& Records of the Royal Society London $5^{6}$ (2002): pp. 3-25. http://rsnr.royalsocietypublishing.org/content $/ 56 / 1 / 3$ \#related-urls

Cerutti, Wim. Haarlems-Amsterdamse duivelskunstenaar: De schilder en vrijdenker Johannes Torrentius (1588-1644). Haarlem: Uitgeverij Loutje, 2014.

Chapman, H. Perry. 'Propagandist Prints, Reaffirming Paintings - Art and Community during the Twelve Years' Truce'. In Arthur K. Wheelock and Adele F. Seeff, eds. The Public and Private in Dutch Culture of the Golden Age, pp. 43-63. Cranbury: Associated University Press, 2000.

Christian, Lynda G. Theatrum mundi: The history of an idea. New York: Garland, 1987.

Coelen, Peter van der. Patriarchs, Angels \& Prophets: The Old Testament in Netherlandish Printmaking from Lucas Van Leyden to Rembrandt. Leiden: Primavera, 1996.

Cohen, Esther. The Modulated Scream: Pain in Late Medieval Culture. Chicago-London: The University of Chicago Press, 2010.

Collins, Christopher, Reading the Written Image: Verbal Play, Interpretation, and the Roots of Iconophobia. University Park, PA: Pennsylvania State University Press, 1991.

Conan, Michel. 'Introduction: The New Horizons of Baroque Garden Cultures'. In Michel Conan, ed. Baroque Garden Cultures: Emulation, Sublimation, Subversion: Colloquium Held at Dumbarton Oaks May 11-12, 2001. Washington, DC: Dumbarton Oaks Research Library and Collection, 2005 .

Coornhert, Dirck Volckertszoon. Boeventucht. Ed. Arie-Jan Gelderblom e.a. Muiderberg: Dick Coutinho, 1985 .

Cordes, Rudolf. Jan Zoet, Amsterdammer 1609-1674: leven en werk van een kleurrijk schrijver. Hilversum: Verloren, 2008.

Costa, Patrizia. The Theater of Jacques Callot. Pittsburgh: University Art Gallery, University of Pittsburgh, 1992. Exhibition catalog.

Dael, Hans van, 'Een toonbeeld van gehoorzaamheid: Ripo en Vondels Jephta of offerbelofte'. De zeventiende eeuw 11, no. 1 (1995): pp. 89-96.

Dapper, O. Historische Beschrijvingh der Stadt Amsterdam. Amsterdam, 1663.

Daston, Lorraine, The Nature of Nature in Early Modern Europe.' Configurations 6, no. 2 (Spring 1998): pp. 149-172. 
Daston, Lorraine. 'The factual sensibility', Isis lxxix (1988): pp. 425-467.

Daston, Lorraine. 'Marvelous Facts and Miraculous Evidence in Early Modern Europe'. In Peter G. Platt. Wonders, Marvels, and Monsters in Early Modern Culture. Newark: University of Delaware Press, 1999 .

Davids, Karel. 'Technological change and the economic expansions of the Dutch Republic 1580-1680'. In Karel Davids and Leo Noordegraaf, eds. The Dutch Economy in the Golden Age: Nine Studies, pp. 79-105. Amsterdam: Nederlandsch Economisch-Historisch Archief, 1973.

Davis, Tracy, 'Theatricality and Civil Society'. In Tracy C. Davis and Thomas Postlewait, eds. Theatricality, pp. 127-155. Cambridge: Cambridge University Press, 2003.

Davis, Tracy C. and Thomas Postlewait, (eds). 'Theatricality: An Introduction', Theatricality. Cambridge: Cambridge University Press, 2003, pp. 1-39.

Dekker, Rudolf. 'Hard gelach in de Gouden Eeuw: Aernout van Overbeeke en zijn moppen,' Literatuur 14 (1997): pp. 359-367.

Dekker, Rudolf. Lachen in de Gouden Eeuw. Amsterdam: Wereldbibliotheek, 1997.

Dekkers, Geertje. 'A. Th. van Deursen over “De Gouden Eeuw compleet”'. Historisch Nieuwsblad 10 (2009) http://www.historischnieuwsblad.nl/nl/artikel/26219/a-th-van-deursen-over-degouden-eeuw-compleet.html

Deleuze, Gilles. 'Deleuze on Spinoza, Cours Vincennes - 24/01/1978', http://www.webdeleuze. $\mathrm{com} / \mathrm{php} /$ texte.php?cle=14\&groupe=Spinoza\&langue=2, last accessed 8 September 2009 .

Deleuze, Gilles. 'The method of dramatization: Paper presented to the Société Française de Philosophie, 28 January 1967'. http://ses.library.usyd.edu.au/bitstream/2123/618/2/adtNU20051202.14522707appendices.pdf

Deleuze, Gilles. Cinéma 1: L’image-mouvement. Paris: Minuit, 1983.

Deleuze, Gilles. Cinéma 2: L'image-temps. Paris: Minuit, 1985.

Deleuze, Gilles, Difference and Repetition. Transl. Paul Patton. New York: Columbia University Press, 1994.

Deleuze, Gilles, Nietzsche and Philosophy. Transl. Hugh Tomlinson. foreword Michael Hardt. New York: Columbia University Press, 2006.

Deleuze, Gilles. Spinoza: Philosophie Pratique. Paris: Minuit, 1981.

Deleuze, Gilles. Spinoza:Practical Philosophy. Translated by Robert Hurley. London: City Light, 2001.

Deleuze, Gilles. The Fold: Leibniz and the Baroque. Foreword and translated by Tom Conley. Minneapolis: University of Minnesota Press, 1992.

Deleuze, Gilles. Le pli: Leibniz et le baroque. Paris: Minuit, 1988.

Derrida, Jacques. 'A Certain Impossible Possibility of Saying the Event.' Transl. Gila Walker. Critical Inquiry, vol. 33, no. 2 (Winter 2007): pp. 441-461.

Descartes, René. 'Meditations on First Philosophy'. In The Philosophical Writings of Descartes, vol. 2. Translated by J. Cottingham, R. Stoothoff and D. Murdoch. Cambridge: Cambridge University Press, 1996.

Deursen, A.Th. Van. Bavianen en Slijkgeuzen: Kerk en kerkvolk ten tijde van Maurits en Oldenbarnevelt. Franeker: Van Wijnen, 1998.

Deursen, A.Th. Maurits van Nassau 1567-1625: De winnaar die faalde. Amsterdam: Bert Bakker, 2000.

Dillen, J.G. Van. 'Documenten betreffende de politieke en kerkelijke twisten te Amsterdam (1614-1630)', Bijdragen en Mededeelingen van het Historisch Genootschap 59 (1938): pp. 200-203.

Dixhoorn, Arjan van. 'Theatre Society in the Low Countries: Performative Culture and the Public Sphere in the Fifteenth and Sixteenth Centuries'. In Jan Bloemendal, ed. Drama, Performance and Debate. The Role of Theatre and Theatricality in Public Opinion in the Early Modern Period. Leiden: Brill, 2013. 
Earle, T.F. and K.J.P. Lowe (eds). Black Africans in Renaissance Europe. Cambridge: Cambridge University Press, 2010.

Eecke, Christophe van. Pandaemonium: Ken Russell's Artist Biographies as Baroque Performances, Maastricht: DataWyse/Universitaire Pers Maastricht, 2015; http://digitalarchive. maastrichtuniversity.nl/fedora/get/guid:b9a991ae-7312-4fe4-a59c-d4b44512b92b/ASSET1

Egginton, William. The Theater of Truth: The Ideology of (Neo)Baroque Aesthetics. Stanford CA: Stanford University Press, 2010.

Emsley, Clive. Crime, Police and Penal Policy: European Experiences 1750-1940. Oxford: Oxford University Press, 2007.

Enden, Franciscus van den. Free Political Propositions and Considerations of State (1665): Text in Translation, the Relevant Biographical Documents and a Selection of Kort Verhael. Introduction, translation, and commentary by Wim Klever. Capelle aan de IJssel: Vrijstad, 2007.

Enden, Franciscus van den. Philedonius. Edited and introduced by Marc Bedjaï and PierreFrancois Moreau. Translated by Selinde Margueron. Paris: Kimé, 1994.

Enden, Franciscus van den. Philedonius, tonneelspel, slaande op de woorden des Wijzemans: 'In alle uwe werken gedenk uwe uitersten, en ghy zult in der eeuwigheit niet zondigen': Ten tonneele gebracht op den ... schouburgh van Amsterdam door Franciscus Van den Enden, ... Translated by Vlooswijck (?) Amsterdam: K. de Bruin, 1657. http://users.telenet.be/fvde/ WorksP/Philedonius_Vlooswijck.pdf

Enden, Franciscus van den. Vrije Politijke Stellingen. Introduced by Wim Klever. Amsterdam: Wereldbibliotheek, 1992.

Enden, Franciscus van den. Kort Verhael van Nieuw Nederlands Gelegenheit, etc. http://www. wdl.org/static/c/4065/service/4065.pdf

Engelen, Marcel van. Het kasteel van El Mina: In het spoor van de Nederlandse slavenhandel in Afrika. Amsterdam: De bezige bij, 2014.

Fabian, Johannes. Time and the Other: How Anthropology Makes Its Object. New York: Columbia University Press, 2002.

Féral, Josette. 'Theatricality: The Specificity of Theatrical Language', SubStance 31, no. 2/3 (1998/99): pp. 94-108.

Filmer, Robert. Patriarcha and Other Writings. Edited by Johann P. Sommerville. Cambridge: Cambridge University Press, 1991, repr. 2000.

Findlen, Paula. 'Historical Thought in the Renaissance'. In Lloyd Kramer and Sarah Maza, eds. Companion to Historical Thought, pp. 99-120. Oxford: Blackwell, 2002.

Findlen, Paula. Possessing Nature: Museums, Collecting, and Scientific Culture in Early Modern Italy. Berkeley: University of California Press, 1994.

Fischer-Lichte, Erika. 'Theatrum vitae humanae.' History of European Drama and Theatre. London: Routledge, 2004, pp. 50-145.

Focquenbroch, Willem G. van. Afrikaense Thalia. Edited byJan Helwig. Deventer: Sub Rosa, 1986. Foucault, Michel. Discipline and Punish: The Birth of the Prison. Translated by Alan Sheridan. New York: Random House, 1977.

Fremantle, Katherine. The Baroque Town Hall of Amsterdam. Utrecht: Haentjes, Dekker en Gumbert, 1959 .

Freund, Peter E.S. 'Social Performances and Their Discontents: The Biopsychosocial Aspects of Dramaturgical Stress'. In G. Bendelow and S. Williams, eds. Emotions in Social Life, pp. 268-293. New York and London: Routledge, 2001.

Frijhoff, Willem, Marijke Carasso-Kok, Maarten R. Prak and Nienke Huizinga, eds. Geschiedenis van Amsterdam. Amsterdam: Boom-Sun, 2004-2009. 
Frijhoff, Willem and Marijke Spies. Dutch Culture in a European Perspective: 1650 , hard-won unity. Assen, Houndmills/New York: Van Gorcum \& Palgrave MacMillan, 2004.

Galilei, Galileo. Dialogue Concerning the Two Chief World Systems. Edited and translated by S. Drake. Berkeley, 1967 .

Garrett, Don, 'Representation and consciousness in Spinoza's naturalistic theory of the imagination' In Charlie Huenemann, ed. Interpreting Spinoza: Critical Essays, pp. 4-25. Cambridge: Cambridge University Press, 2008.

Geerdink, Nina. Dichters enverdiensten:De sociale verankering van het dichterschap van Jan Vos (1610-1667). Hilversum: Verloren, 2012.

Geertz, Clifford. Negara: The Theatre State in 19th Century Bali. Princeton: Princeton University Press, 2001.

Gemert, Lia van. 'The Politics of Visuality in Dutch Renaissance Tragedy'. In: Maria-Theresia Leuker (Hrsg.), Die Sichtbare Welt. Visualität in der niederländischen Literatur und Kunst des 17. Jahrhunderts. Münster/New York,/München/Berlin: Waxmann, 2012, pp. 203-219.

Gemert, Lia van. 'Severing what was Joined Together: Debates about Pain in the Seventeenth Century Dutch Republic'. In: J.F. van Dijkhuizen \& K.A.E. Enenkel (eds), The Sense of Suffering: Constructions of Physical Pain in Early Modern Culture. Leiden/Boston: Brill, 2009, pp. $443-468$.

Genette, G. Nouveau discours du récit, Paris: ED. Du Seuil, 1983.

Gibbs, G.C. 'The role of the Dutch Republic as the intellectual entrepôt of Europe in the seventeenth and eighteenth centuries.' BMGN - Low Countries Historical Review 86, no. 3 (1971): pp. 323-349.

Glissant, Édouard. Poetics of the Relation. Transl. Betsy Wing. Ann Arbor: University of Michigan Press, 1997.

Gluklich, Ariel. Sacred Pain: Hurting the Body for the Sake of the Soul. Oxford: Oxford University Press, 2003.

Goetschel, R. 'Le Sacrifice d'Isaak dans le 'Gebia Kesef” de Joseph Ibn Kaspi'. Pardes 22 (1996): pp. $69-82$.

Greenfeld, Liah. The Spirit of Capitalism: Nationalism and Economic Growth. Cambridge, MA: Harvard University Press, 2001.

Gregg, Melissa, and Gregory J. Seigworth. The Affect Theory Reader. Durham, NC: Duke University Press, 2010.

Grevius, Johannes. Tribunal reformatum in quo sanioris et tutioris justitiae via judici christiano in processu criminali commonstratur, reiecta et fugata tortura. Gvelpherbiti, sumptibus I.C. Meisneri, 1737 .

Grootenboer, Hanneke. The Rhetoric of Perspective: Realism and Illusionism in 17 th century Dutch Still-Life Painting. Chicago: Chicago University Press, 2005.

Grotius, Hugo. Briefwisseling van Hugo Grotius. Deel 1o. Edited by B.L. Meulenbroek. Martinus Nijhoff, Den Haag, 1976.

Grotius, Hugo. Commentary on the Law of Prize and Booty. Translated by Gladys L. Williams. Edited by Martine Julia van Ittersum. Indianapolis, IN: Liberty Fund, 2006.

Grotius, Hugo. De imperio summarum potestatum circa sacrum, volume 1. Introduction, translation and commentary by Harm-Jan van Dam. Leiden: Brill, 2001.

Grotius, Hugo. Meletius or Letter on the Points of Agreement Between Christians. Leiden: Brill, 1988.

Grotius, Hugo. The Antiquity of the Batavian Republic, with the notes by Petrus Scriverius. Edited and translated by Jan Waszink et al. Assen: Van Gorcum, 2000.

Grotius, Hugo. The Rights of War and Peace, in Three Books, etc. London 1738, repr. Clark, New Jersey: The Lawbook Exchange Ltd., 2004. 
Haeger, Barbara. 'Frans Hals so-called Jonker Ramp and his sweetheart reconsidered'. Konsthistorisk tidskrift 55 , no. 4 (1986).

Halpern, Richard. 'Theatre and Democratic Thought: Arendt to Rancière', Critical Inquiry 37, no. 3 (Spring 2011): pp. 545-572.

Hanaf, Zakiya. The Monster in the Machine: Magic, Medicine, and the Marvelous in the Time of the Scientific Revolution. Durham, NC: Duke University Press, 200o. http://public.eblib.com/ choice/publicfullrecord.aspx? $\mathrm{p}=1167549$

Hannam, James. God's Philosophers: How the Medieval World Laid the Foundations of Modern Science. London: Icon Books, 2009.

Hartkamp-Jonxis, Ebeltje. 'Mannerist, Baroque, and Classicist: Narrative Tapestries and Related Paintings in Late Sixteenth- and Seventeenth-Century Holland'. In Thomas P. Campbell and Elizabeth A.H. Cleland, eds. Tapestry in the Baroque: New Aspects of Production and Patronage, pp. 134-153. New York: The Metropolitan Museum of Art, 2010.

Heller Roazen, Daniel. The Inner Touch:Archaeology of a Sensation. New York:Zone Books, 2007. Helmers, Helmer. 'The Politics of Mobility: Shakespeare's Titus Andronicus, Jan Vos' Aran and Titus and the Poetics of Empire'. In Jan Bloemendal \& Nigel Smith, Politics and Aesthetics in European Baroque and Classicist Tragedy, Leiden: Brill, 2016, pp. 344-372.

Heppner, A. 'Pieter Quast and P.C. Hooft'. Maandblad voor beeldende kunst 14, (1937).

Herklotz, Ingo. 'Forschungberichte: Neue Literatur zur Sammlungsgeschichte'. Kunstchronik xlvii (1994): pp. 117-35.

Hills, Helen, ed. Rethinking the Baroque. Farnham: Ashgate, 2011.

Hollander, August den, Alex Noord, Mirjam van Veen, and Anna Vooistra (eds), Religious Minorities and Cultural Diversity in the Dutch Republic: Studies Presented to Piet Visser on the Occasion of his 65th Birthday. Leiden: Brill, 2014.

Hooft, P.C. Baeto. Edited by F. Veenstra. The Hague: Martinus Nijhoff, 1980.

Hooft, P.C. Nederlandsche historiën. In: W.Gs. Hellinga \& P. Tuynman (eds), Alle de gedrukte werken 1611-1738. Amsterdam: Amsterdam University Press, [1972] 2007.

Hoogendoorn, W. 'Sieraaden van het tooneel. Iets over vertoningen in de Amsterdamse schouwburgen van 1637 en 1665.' In memoriam Dr. W.Ph. Pos. Scenarium (1978), nr. 2, pp. 70-82.

Hooper-Greenhill, Eilean. 'The art of memory and learning in the museum: the challenge of GCSE'. International Journal of Museum Management and Curatorship 7, no. 2 (1988): pp. 129-137.

Horswell, Michael J. 'Baroque and Neo-baroque Literary Tradition', Latin American Studies (2013) http://dx.doi.org/10.1093/obo/9780199766581-0004

Houbraken, Arnold, De groote schouburgh der Nederlantsche konstschilders en schilderessen. Amsterdam: B.M. Israël, 1976.

Huygens, Christiaan. Cosmotheoros: The celestialworlds discover'd: or, Conjectures concerning the in habitants, plants and productions of the worlds in the planets. London: Timothy Childe, 1698.

Huygens, Constantijn. Heilighe daghen. Introduced by L. Strengholt, Amsterdam: Buijten \& Schipperheijn, 1974.

Huygens, Constantijn, 'Sondagh'. http://www.kb.nl/dichters/huygens/huygens-o6.html Huygens, Constantijn. Briefwisseling. Deel 3:1640-1644. Edited by J.A. Worp. The Hague: Martinus Nijhoff, 1914. http://www.dbnl.org/tekst/huygoo1jaw005_01/huygoo1jawo05_01_0630.php

Huygens, Constantijn. Gedichten. Deel 6:1656-1661. Edited by J.A. Worp. Groningen: Wolters, 1896. http://www.dbnl.org/tekst/huygooijaw014_01/huygoo1jaw014_01_0004.php

Huygens, Constantijn. Heilige Dagen. http://www.let.leidenuniv.nl/Dutch/Huygens/Heilige Dagen.html 
Israel, Jonathan. Radical Enlightenment:Philosophy and the Making of Modernity. Oxford: Oxford University Press, 2001.

Israel, Jonathan. Enlightenment Contested:Philosophy, Modernity, and the Emancipation of Man, 1670-1752. Oxford: Oxford University Press, 2006.

Ittersum, M.J. van. 'Hugo Grotius in Context: Van Heemskerck's Capture of the Santa Catarina and its Justification in De Jure Praedae (1604-1606).' Asian Journal of Social Science 31, no. 3 (2003): pp. 511-524.

Ittersum, M.J. van. Profit and Principle. Hugo Grotius, Natural Rughts Theories and the Rise of Dutch Power in the East Indies (1595-1615). Leiden/Boston: Brill, 2006.

Jackson, H.J. Marginalia: Readers Writing in Books. New Haven/London:Yale University Press, 2001. Jacob, Margaret. The Radical Enlightenment: Pantheists, Freemasons and Republicans. New Orleans: Cornerstone Book Publishers, 2006.

James, S. Passion and Action: The Emotions in 17th century Philosophy. Oxford: Oxford University Press, 1997 .

James, William. Essays in RadicalEmpiricism. Introduction by E.K. Suckiel. Preface by R.B. Perry. Lincoln: University of Nebraska Press, 1996.

Jameson, Frederic. The Ideologies of Theory. New York/London: Verso, 2008.

Janssen, Johannes. History of the German People After the Close of the Middle Ages. Vol. 16. Translated by A.M. Christie. London: Kegan Paul, 1910.

Jay, Martin. Force Fields: Between Intellectual History and Cultural Critique. London: Routledge, 1993. Joly, Bernard. 'Could a Practicing Chemical Philosopher Be a Cartesian.' In Mihnea Dobre and Tammy Nyden, eds. Cartesian Empiricisms. Dordrecht: Springer, 2013.

Jonctys, Daniél. De pyn-bank wedersproken, en bematigt. Rotterdam, 1651.

Jorink, Eric. 'Tekenen van Gods gramschap: Wonderbaarlijke natuurverschijnselen in de Republiek in de 16e en 17 e eeuw', Groniek 127 (1995), pp. 176-188.

Jorink, Eric. Wetenschap en wereldbeeld in de Gouden Eeuw. Hilversum: Verloren, 1999.

Jorink, Eric. 'Van omineuze tot glorieuze tekens. Veranderende opvattingen over kometen in de zeventiende eeuw' in: F. Egmond, E. Jorink and R. Vermij eds., Kometen, monsters en muilezels. Het veranderende natuurbeeld en de natuurwetenschap in de zeventiende eeuw. Haarlem: Arcadia, 1999, pp. 89-104.

Jorink, Eric. “'Outside God there is nothing”: Swammerdam, Spinoza, and the Janus-Face of the Early Dutch Enlightenment'. In Wiep van Bunge, ed. The Early Enlightenment in the Dutch Republic, 1650-1750. Leiden: Brill, 2003, pp. 81-109.

Jorink, Eric. Het 'Boeck der Natuere'. Nederlandse geleerden en de wonderen van Gods schepping 1575-1715. Leiden: Primavera Pers, 2006.

Jorink, Erik. Reading the Book of Nature in the Dutch Golden Age, 1575-1715. Transl. Peter Mason. Leiden: Brill, 2010.

Jorink, Eric, and Dirk van Miert, eds. Isaac Vossius, 1618-1689) between Science and Scholarship. Leiden: Brill, 2009.

Kahn, Paul W. Sacred Violence: Torture, Terror, and Sovereignty. Ann Arbor: University of Michigan Press, 2008.

Kamen, Henry. The Spanish Inquisition: A Historical Revision. New Haven: Yale University Press, 1998.

Kaplan, Benjamin J. Divided by Faith. Religious Conflict and the Practice of Toleration in Early Modern Europe. Cambridge, MA: Harvard University Press, 2007.

Katritzky, Peg. 'Pickelhering and Hamlet in Dutch art: The English comedians of Robert Browne, John Green, and Robert Reynolds', In Douglas A. Brooks, ed. Shakespeare and the Low Countries, pp. 113-140. New York: Edwin Mellen, 2005. 
Kimbrough, Erik O., Vernon L. Smith and BartJ. Wilson. 'Exchange, theft, and the social formation of property.' Journal of Economic Behavior \& Organization 74, no. 3 (June 2010): pp. 206-229.

Kleiner, Fred. S. Gardner's Art Through the Ages: A Global History. Fourteenth edition. Boston: Wadsworth, 2012.

Kolfin, Elmer. The Young Gentry at Play: Northern Netherlandish Scenes of Merry Companies 1610-1645. Leiden: Primavera, 2005.

Koopmans, Jelle. 'The University out on the streets: Drama, Debate and Public Space in France (1490-1520)'. In Jan Bloemendal, ed. Drama, Performance and Debate. The Role of Theatre and Theatricality in Public Opinion in the Early Modern Period, pp. 57-8o. Leiden: Brill, 2013.

Korsten, Frans-Willem. 'God as a Keystone to the System of Commonplaces - The Case of Joost van den Vondel's Plays'. In K. Banks and P. Bossier, eds. Commonplace Culture in Western Europe in the Early Modern Period, vol. II: The Consolidation of God-Given Power. Leuven: Peeters, 2010.

Korsten, Frans-Willem. Sovereignty as Inviolability: Vondel's Theatrical Explorations in the Dutch Republic. Hilversum: Verloren, 2009.

Korsten, Frans-Willem, “But did they not, with it, burn the excrements as well?': Macropedius' Experimental Plays, or Humanism as Avant-garde'. In Jan Bloemendal, ed. The Latin Playwright Georgius Macropedius (1457-1558) in European Contexts; European Medieval drama, 13 (2009), pp. 117-136.

Kramer, W. Vondel als Barokkunstenaar. Antwerpen/Utrecht: De Haan, 1946.

Kroon, Andréa. 'Masonic networks, material culture \& international trade. The participation of Dutch freemasons in the commercial \& cultural exchange with Southeast Asia, 1735-1853'. PhD diss., University of Leiden, 2015.

Lambert, Gregg. The Return of the Baroque in Modern Culture. London: Continuum, 2004.

Langbein, John H. Torture and the Law of Proof: Europe and England in the Ancien Régime. Chicago: University of Chicago Press, 2012 [1976].

Langbein, John. 'Torture and Plea Bargaining', The University of Chicago Law Review 46 (1978): pp. $3^{-22 .}$

Langford, Michelle, Allegorical Images: tableau, time and gesture in the cinema of Werner Schroeter, Bristol: Intellect, 2006.

Large, P.J., trans. 'Religious Poems of Constantijn Huygens.' http://www.hull.ac.uk/php/abspjl/ Dutch/Huygens/Willig.html

Lear, Floyd Seyward. Treason in Roman and Germanic Law. Austin: University of Texas Press, 1965 [2011].

Lehman, Hans-Thies. Postdramatic Theatre. Translated by Karen Jürs-Munby. London: Routledge, 2006.

Leibniz, Gottfried Wilhelm. Theodicy: Essays on the Goodness of God, the Freedom of Man, and the Origin of Evil. La Salle, IL: Open Court, 1985.

Leo, Russ. 'Affective Physics: Affectus in Spinoza's Ethica'. In Brian Cummings and Freya Sierhuis, eds. Passions and Subjectivity in Early Modern Culture, pp. 33-50. Farnham and Burlington, VT: Ashgate, 2013.

Leuker, Maria. 'Im Buch der Natur lesen: Antikerezeption in den naturkundlichen Werken des Georgius Everhardus Rumphius (1627-1702)', In Dietrich Boschung and Erich Kleinschmidt, eds. Lesbarkeiten: Antikrezeption zwischen Barock und Aufklärung, pp. 243-268. Königshausen und Neumann Verlag, 2010.

Leuvensteijn, Arjan van. 'Een man, een man, een woord een moord?: De Jefta uit Richteren bij De Koning en Vondel'. Voortgang 23 (2005): pp. 107-128.

Levack, Brian P. 'The Decline and End of Witchcraft Prosecutions.' In Helen Parish, ed., Superstition and Magic in Early Modern Europe: A Reader. London/New York: Bloomsbury Academic, 2014. 
Levillain, Charles-Edouard. 'William III's Military and Political Career in Neo-Roman Context 1672-1702'. The Historical Journal 48 (2005): pp. 321-50.

Lewis, David K. Counterfactuals. Cambridge: Harvard University Press, 1973.

Lewis, David K. On the Plurality of Worlds. Oxford: Blackwell, 1986.

Loh, Maria H., 'New and Improved: Repetition as Originality in Italian Baroque Practice and Theory'. The Art Bulletin 86, No. 3 (September 2004): pp. 477-504.

Lütke Notarp, Gerlinde. Von Heiterkeit, Zorn, Schwermut und Lethargie: Studien zur Ikonographie der vier Temperamente in der niederländischen Serien- und Genregraphik der 16. Und 17. Jahrhunderts. Münster: Waxmann, 1998.

Machiavelli, Niccolò, The Prince. Translated by George Bull. London: Penguin, 1999.

Mack, Michael. Sidney's Poetic: Imitating Creation. Washington DC: The Catholic University of America Press, 2005.

Mandrou, Robert, 'Baroque Européen: mentalité pathétique et revolution sociale'. Annales. Économies, Sociétés, Civilisations, vol. 15, 1960:5, pp. 898-914.

Mahoney, Michael S. 'Sketching Science in the 17th century'. http://www.princeton.edu/ hos/ mike/articles/whysketch/whysketch.html

Mander, Karel van. Het schilder-boeck, facsimile, Haarlem 1604. Utrecht: Davaco Publishers, 1969. http://www.dbnl.org/tekst/mandoo1schio1_01/

Marsilius of Padua. The Defender of the Peace. Edited and translated by Annabel Brett. Cambridge: Cambridge University Press, 2005.

Martin, John Rupert. Baroque. Hammondsworth: Penguin, 1991.

MacKenzie, Iain and Robert Porter. Dramatizing the Political: Deleuze and Guattari. London: Palgrave MacMillan, 2011.

MacKenzie, Iain and Robert Porter. 'Dramatization as method in political theory', Contemporary Political Theory Vol. 10:4, pp. 482-501.

McGavin, John. Theatricality and Narrative in Medieval and Early Modern Scotland. Aldershot and Burlington: Ashgate, 2007.

McGrath, Alister E. Johannes Calvijn. Verlicht hervormer of vormgevervan een orthodox keurslijf? Baarn: Tirion, 1995 .

Meillassoux, Quentin. Finitude: An Essay on the Necessity of Contingency. Translated by Ray Brassier. New York: Continuum, 2010.

Mellor, Alec. Un chefd'oeuvre méconnu: les 'tribunal reformatum'de Grevius (1624). Paris: Sirey, 1949.

Mérot, Alain. Généalogies du baroque. Paris: Gallimard, 2007.

Mertens, Frank, ed. Online documents regarding Franciscus van den Enden. http://users. telenet. be/fvde/

Metropolitan Museum of Art (New York, N.Y.). Europe in the Age of Monarchy. New York: The Museum, 1987 .

Meuwese, Mark. Brothers in Arms, Partners in Trade: Dutch-Indigenous Alliances in the Atlantic World, 1595-1674. Leiden: Brill, 2012.

Michael Servetus Institute. http://www.miguelservet.org/servetus/web.php

Mitchell, W.T. Blake's Composite Art: A Study of the Illuminated Poetry. Princeton: Princeton University Press, 1978.

Moerkerken, P.H. van. Adriaan Koerbagh: Een strijder voor het vrije denken. Amsterdam: G.A. van Oorschot, 1948.

Mooney, Edward F. 'Kierkegaard's Job Discourse: Getting Back the World', International Journal for Philosophy of Religion 34, No. 3 (December 1993): pp. 151-169.

Mortimer, Sarah and John Robertson, eds. The Intellectual Consequences of Religious Heterodoxy. Leiden: Brill, 2012. 
Moss, Ann. Printed Commonplace Books and the Structuring of Renaissance Thought. Oxford: Clarendon Press, 1996.

Moss, Ann. Renaissance Truth and the Latin Language Turn. Oxford: Oxford University Press, 2003. Mouffe, Chantal. On the Political. London: Routledge, 2005.

Nadler, Allan. 'Springtime for Spinoza'. http://www.forward.com/articles/4892/ (13 October 2006). Nadler, Steven. Spinoza: A Life. Cambridge: Cambridge University Press, 1999.

Nagel, Alexander, and Christopher S. Wood. Anachronic Renaissance. New York: Zone Books, 2010.

Naya, Juan and Marian Hillar, eds. Michael Servetus, Heartfelt: Proceedings of the International Servetus Congress, Barcelona, 20-21 October 2006. Lanham: University Press of America, 2011.

Ndalianis, Angela. Neo-Baroque Aesthetics and Contemporary Entertainment. Cambridge, MA: MIT Press, 2004.

Nederlandse liederenbank: http://www.liederenbank.nl/bronpresentatie.php?zoek=10844\&lan=nl (visited March 2017).

Negri, Antonio. The Savage Anomaly: The Power of Spinoza's Metaphysics and Politics. Minneapolis: University of Minnesota Press, 1999.

Nellen, Henk. Hugo Grotius, a lifelong struggle for peace in church and state, 1583-1645. Leiden: Brill, 2014.

Netanyahu, Benzion. The Origins of the Inquisition in Fifteenth Century Spain. New York: New York Review Books, 2001.

Nevitt, H. Rodney. Art and the Culture of Love in Seventeenth-Century Holland. Cambridge: Cambridge University Press, 2003.

Nierop, Henk van. Het verraad van het Noorderkwartier. Oorlog, terreur en recht in de Nederlandse Opstand. Amsterdam: Bert Bakker, 1999.

Nietzsche, Friedrich Wilhelm. The Birth of Tragedy. Translated by Douglas Smith. Oxford: Oxford University Press, 2008.

Nyqist, Mary. Arbitrary Rule: Slavery, Tyranny and the Power of Life and Death. Chicago: Chicago University Press, 2013.

O’Bryan, Robin. 'Grotesque Bodies, Princely Delight: Dwarfs in Italian Renaissance Court Imagery,' Preternature: Critical and Historical Studies on the Preternatural 1, no. 2 (2012): pp. $252-288$.

Ooghen-Troostproject. Universiteit Gent. http://www.nederlandseliteratuur.ugent.be/ onderzoek/Ooghentroost

Oudaen, Joachim. Poezy. Amsterdam: Wed. P. Arentz and K. vander Sys, 1712.

Overbeke, Aernout van. Buyten gaets. Twee burleske reisbrieven van Aernout van Overbeke. Edited by Marijke Barend-van Haeften and Arie Jan Gelderblom. Verloren: Hilversum, 1998.

Overbeke, Aernout van. Geestige en Vermaeckelicke Reys-beschryvinge Van den Heer Aernout van Overbeke Naer Oost-Indiën gevaren, ten dienste van de E.E. Heeren Bewinthebberen van de Oost-Indische Compagnie, Voor Raet van Justitie, in den Jare 1668. Vervattende verscheyde kluchtige voorvallen, en koddige gedachten op de selve, geduerende sijn Reyse van Amsterdam tot Batavia. Amsterdam: Jan Joosten, 1671.

Ovid. Metamorphoses. Edited by Madeleine Forey. Translated by Arthur Godling. Baltimore: Johns Hopkins University Press, 2002.

Paalvast, Peter. Martelen en martelwerktuigen in cultuurhistorische perspectief. Zoetermeer: Free Musketeers, 2011.

Paijmans, Marrigje. Dichter bij de waarheid: parrhesia en de dramatisering in het werk van Joost van den Vondel. PhD diss., University of Amsterdam, 2015.

Panhuysen, Luc. De ware vrijheid: de levensvan Johan en Cornelis de Witt. Amsterdam: Olympus, 2015. 
Parish, Helen, ed. Superstition and Magic in Early Modern Europe: A Reader. London/New York: Bloomsbury Academic, 2014.

Peden, Knox. Spinoza Contra Phenomenology: Rationalism from Cavaillès to Deleuze. Stanford: Stanford University Press, 2014.

Peters, Edward. Inquisition. Berkeley: University of California Press, 1989.

Peters, Edward. Torture. London: Basil Blackwell, 1986.

Pieters, J. 'In denkbeeldige tegenwoordigheid. Naar een New Historicism van de Lage Landen'. Spiegel der Letteren 47, no. 3 (2005): pp. 251-271.

Pieters, Jurgen. 'Coornhert en Calvijn over Job: de lijdzaamheid van de redelijke mens versus de almacht van de afwezige God'. In Jaap Gruppelaar en Jürgen Pieters, eds. 'Un certain Holandois': Coornhert en de vragen van zijn tijd, pp. 55-74. Hilversum: Verloren, 2014.

Pike, David Lawrence. Passage Through Hell:Modernist Descents, Medieval Underworlds. Ithaca, NY: Cornell University Press, 1997.

Pinacoteca Vaticana.http://mv.vatican.va/3_EN/pages/xSchede/PINs/PINs_Sala15_o8_059.html 'Plakkaat van Verlatinghe 1581 july 26'. In George M. Welling. 'American History: From Revolution to Reconstruction and Beyond. Accessed 15 August 2014. http://www.let.rug.nl/usa/ documents/before-160o/plakkaat-van-verlatinghe-1581-july-26.php

Platt, Peter G., ed. Wonders, Marvels, and Monsters in Early Modern Culture. Newark: University of Delaware Press, 1999.

Pocock, J.G.A. The Machiavellian Moment: Florentine Political Thought and the Atlantic Republican Tradition. Princeton NJ: Princeton University Press, 2003.

Poelhekke, J.J. Frederik-Hendrik, Prins van Oranje. Een biografisch drieluik. Zutphen: De Walburg Pers, 1978.

Pölönen, Jane. 'Plebeians and Repression of Crime in the Roman Empire: From Torture of Convicts to Torture of Suspects'. Revue internationale des droits de L'Antiquité 51 (2004): pp. 217-57.

Postma, J.M. The Dutch in the Atlantic slave trade, 160o-1815. Cambridge [etc.]: Cambridge University Press, 1990.

Pranger, Burcht. The Artificiality of Christianity: Essays on the Poetics of Monasticism. Stanford, CA: Stanford California Press, 2003.

Price, Leslie J. The Dutch Republic in the Seventeenth Century. London: Palgrave MacMillan, 1998. Prud'homme van Reine, R.B. 't Paerlen op de kroon der Gallerij. De schilderijen van de zeventiende-eeuwse zeeofficierenfamilie Van Nes in het Rijksmuseum', Bulletin van het Rijksmuseum 43, no. 2 (1995): pp. 96-112.

Prud'homme van Reine, Ronald. Moordenaars van Jan de Witt: de zwartste bladzijde van de Gouden Eeuw. Amsterdam: Arbeiderspers, 2013.

Rancière, Jacques. The Politics of Aesthetics: The Distribution of the Sensible. Introduced and translated by Gabriel Rockhill. London: Continuum, 2004.

Reinders, Michel. Printed Pandemonium: Popular Print and Politics in the Netherlands $1650-1672$. Leiden: Brill, 2013.

Roemer, Bert van de. 'Neat nature: the relation between nature and art in a Dutch cabinet of curiosities from the early eighteenth century'. History of Science 42 (2004): pp. 47-84.

Roscam Abbing, M.V. 'Rembrandt toont sijn konst. Bijdragen over Rembrandt-documenten uit de periode 1648-1756'. PhD diss., University of Amsterdam, 1999.

Rousset, Jean. La littérature de l'age baroque en France: Circé et le paon. Paris: Corti, 1953.

Rozekruisers Orde A.M.O.R.C., 'Johannes Torrentius'. https://www.amorc.nl/over-amorc/ geschiedenis/johannes-torrentius

Rumphius, G.E. The Ambonese Curiosity Cabinet. Edited and translated by E.M. Beekman. New Haven, CT [etc.]: Yale University Press, 1999. 
Sarrazac, Jean-Pierre. Poétique du drame moderne. Paris: Les Éditions du Seuil, 2012.

Sawday, Jonathan. The Body Emblazoned:Dissection and the Human Body in Renaissance Culture. London: Routledge, 1996.

Scarry, Elaine. The Body in Pain: The Making and Unmaking of the World. Oxford: Oxford University Press, 1986.

Schama, Simon. The Embarrassment of Riches: An Interpretation of Dutch Culture in the Golden Age. New York: Alfred Knopf, 1987.

Scheiner, Susan. Where Shall Wisdom be found? Calvin's Exegesis ofJob from Medieval and Modern Perspectives. Chicago/London: University of Chicago Press, 1994.

Schiller, Noël. “To see ourselves greatly misled': The laughing deception of Jan Miense Molenaer's Five Senses (1637)'. Canadian Journal of Netherlandic Studies XVIII (2007): pp. 76-103.

Schiller, Noël. 'The Art of Laughter: Society, Civility and Viewing Practices in the Netherlands 1600-1640'. PhD diss., University Of Michigan Ann Arbor, 2006.

Schmid, Vincent. Michel Servet: du bûcher à la liberté de conscience. Paris: Editions de Paris, 2008.

Schmidt, Benjamin. Inventing Exoticism: Geography, Globalism and Europe's Early Modern World. Philadelphia: University of Pennsylvania Press, 2015.

Schochet, Gordon J. Patriarchalism and Political Thought: The Authoritarian Family and Political Speculation and Attitudes Especially in Seventeenth-Century England. New York: Basic Books, 1975.

Schoemaker, Kees. 'Het huwelijk van Messalina en Gaius Silius, ofwel bigamie in het oude Rome, geschilderd door Nicolaus Knüpfer'. Bulletin van het Rijksmuseum 52 (2004): pp. 173-76.

Schramm, Helmar. Karneval des Denkens. Theatralität im Spiegel philosophischer Texte des 16. und 17. Jahrhunderts. Berlin: Akademie Verlag, 1996.

Sepper, Dennis. Descartes'Imagination:Proportion, Images, and the Activity of Thinking. Berkeley and Los Angeles: California University Press, 1996.

Shakespeare, William. The Complete Works. Edited by Stanley Wells and Gary Taylor. Oxford: Clarendon Press, 2006.

Shapiro, Gary. Archaeologies of Vision: Foucault and Nietzsche on Seeing and Saying. Chicago and London: University of Chicago Press, 2003.

Sidney, Philip. An Apology For Poetry (Or The Defence Of Poesy). (Revised and expanded Third Edition). Edited by Geoffrey Shepherd and R.W. Maslen. Manchester: Manchester University Press, 2002.

Sierhuis, Freya. The Literature of the Arminian Controversy: Religion, Politics and the Stage in the Dutch Republic. Oxford: Oxford University Press, 2015.

Silverman, Lisa. Tortured Subjects: Pain, Truth and the Body in Early Modern France. Chicago: University of Chicago Press, 2001.

Silvestris, Bernard. Commentary on the first six books of the Aeneïd. Edited by Earl G. Schreiber and Thomas E. Maresca. Lincoln: University of Nebraska Press, 1979.

Simmel, Georg. The Conflict in Modern Culture and other Essays. Translated by K.P. Etzkorn. New York: Teachers College Press, 1968.

Singer, Peter. 'Unspeakable Acts'. New York Review of Books 33, no. 3 (1986) http://www.nybooks. com/articles/archives/1986/feb/27/unspeakable-acts/

Skinner, Quentin. 'On the Liberty of the Ancients and the Moderns: A Reply to My Critics'. Journal of the History of Ideas 73 (2012): pp. 127-46.

Skinner, Quentin. 'Rethinking Political Liberty', History Workshop Journal 61 (2006): pp. 156-170. Skinner, Quentin. The Foundations of Modern Political Thought: The Renaissance. Cambridge: Cambridge University Press, 1978. 
Skinner, Quentin. Visions of Politics: Regarding Method. Cambridge: Cambridge University Press, 2002.

Skinner, Quentin. Visions of Politics: Renaissance Virtues. Cambridge: Cambridge University Press, 2002.

Slive, Seymour and Peter Biesboer, Frans Hals. Munich: Prestel, 1989.

Slive, Seymour. Frans Hals. Volume 1. National Gallery of Art: Kress Foundation, Studies in the History of European Art. London: Phaidon Press, 1970.

Slive, Seymour. Frans Hals. Volume 3. National Gallery of Art: Kress Foundation, Studies in the History of European Art. London: Phaidon Press, 1974.

Small, Graeme. 'Introduction to the 2002 edition'. In Richard Vaughan. Philip the Good: The Apogee of Burgundy, pp. xix-lii. Woodbridge: Boydell Press, 2011.

Smit, W.A.P. Van Pascha tot Noah. Deel 2: Salomon - Koning Edipus. Zwolle: W.E.J. Tjeenk Willink, 1970.

Smits-Veldt, Mieke B. 'Vertoningen in opvoeringen van Vondels tragedies 1638-1720: van emblema tot 'sieraad". De zeventiende eeuw 11 (1995): pp. 210-218.

Smits-Veldt. Mieke B. 'Bredero en Timanthes'. Spektator 14 (1984/85): pp. 288-294.

Spanks Jennifer and Charles Zika (eds), Disaster, Death and the Emotions in the Shadow of the Apocalypse 1400-1700. London: Palgrave MacMillan, 2016.

Spierenburg, Pieter. The Prison Experience: Disciplining Institutions and their Inmates in Early Modern Europe. Amsterdam: Amsterdam University Press, 2007.

Spies, Marijke. 'Amsterdamse doolhoven. Populair cultureel vermaak in de zeventiende eeuw.' Literatuur 18 (2001): pp. 70-78.

Spies, Marijke. 'Het epos in de $17 \mathrm{e}$ eeuw in Nederland: een literatuurhistorisch probleem.' Spektator 7 (1977/78): pp. 379-411.

Spinoza, Benedict de. Ethics. Translated by E.M. Curley. London: Penguin, 2004.

Spinoza, Benedict de. Theological-Political Treatise. Edited and translated by Jonathan Israel. Translated by Michhael Silverthorne. Cambridge: Cambridge University Press, 2007.

'Stadhuis paleis op de Dam. Thesaurie. Functie. Inhoud.' https://17burgers.wordpress. com/2013/05/o3/Stadhuis-Paleis-Op-De-Dam-Thesaurie-Functie-Inhoud/

Sterck, J.F.M. Hoofdstukken over Vondel en zijn kring - met prenten en facsimiles. Amsterdam: Van Looy, 1923.

Stipriaan, René van. Leugens en vermaak: Boccacio's novellen in de kluchtcultuurvan de Nederlandse renaissance. Amsterdam: Amsterdam University Press, 1996.

Stipriaan, René van. 'Het theatrum mundi als ludiek labyrint: De vele gedaanten van het rollenspel in de zeventiende eeuw', De zeventiende eeuw 15 (1999): pp. 12-22.

Stipriaan, René van. 'De mythe van de miskenning of de grillige roem van Willem Godschalck van Focquenbroch'. Fumus 5 (2007): pp. 29-39.

Stipriaan, René van. Het volle leven: Nederlandse literatuur en cultuur ten tijde van de Republiek (circa 1550-1800). Amsterdam: Prometheus, 2007.

Stipriaan, René van. Lof der botheid: Hoe de Hollanders hun nä̈viteit verloren. Amsterdam: Querido, 2016.

Stoichita, Victor Ieronim. The Self-Aware Image: An Insight into Early Modern Meta-Painting. Cambridge: University Press, 1997.

Te Winkel, Jan. De ontwikkelingsgang der Nederlandsche letterkunde. IV. Geschiedenis der Nederlandsche letterkunde van de Republiek der Vereenigde Nederlanden (2). Tweede druk. Haarlem: De erven F. Bohn, Haarlem, 1924.

Thiel, P.J.J. Van. 'De betekenis van het portret van Verdonck door Frans Hals'. Oud Holland (1980): pp. 112-140. 
Thiel, Pieter J.J. Van. 'Moeyaert and Bredero: A Curious Case of Dutch Theatre as Depicted in Art,' Simiolus: Netherlands Quarterly for the History of Art 6, no. 1 (1972/73): pp. 29-49.

Trivas, Numa S. The Paintings of Frans Hals: Complete Edition. London: George Allen \& Unwin, 1941.

Tummers, Anna, ed. De Gouden Eeuw viert feest. Rotterdam: NAi, 2012.

Tummers, Anna, ed. Celebrating in the Golden Age. Rotterdam: NAi, 2012.

Turner, Henry S., ed. Early Modern Theatricality. Oxford Twenty-First Century Approaches to Literature. Oxford and New York: Oxford University Press, 2013.

Uitman. J.E. 'Les fêtes baroques d'Amsterdam de 1638 à 166o. L'intelligibilité de leurs motifs allégoriques et historiques pour le public contemporain'. In Jean Jacquot, ed. Dramaturgie et société, pp. 221-226. Paris, 1968.

Verberckmoes, Johan. Schertsen, schimpen en schateren. Geschiedenis van het lachen in de Zuidelijke Nederlanden, zestiende en zeventiende eeuw. Nijmegen: SUN, 1998.

Verbrugge, Rita. 'Huygens' Pilgrimage Through the Calendar Year'. Canadian Journal of Netherlandic Studies 15, no. 1 (1994): pp. 1-6.

Vergil. Eclogues - Georgics - Aeneid 1-6. Transl. H. Rushton Fairclough, rev. G.P. Goold. Loeb Classics. Cambridge Mass.: Harvard University Press, 1999.

Verschaffel, Bart. 'Rome: Over theatraliteit'. Vlees en Beton 16 (1990): pp. 5-52.

Vighi, Fabio and Heiko Feldner. Žižek Beyond Foucault. Houndmills/New York: Palgrave MacMillan, 2007 .

Vink, Markus. Review or August den Hollander (e.a.), Religious Minorities and CulturalDiversity in the Dutch Republic (etc.), Journal of Early Modern History Vol. 20:5 (2016), pp. 504-507.

Vlaardingebroek, Pieter. De geschiedenis van het stadhuis van Amsterdam. Zwolle:WBooks, 2011.

Vondel, Joost van den, De werken van Vondel: Volledige en geïllustreerde tekstuitgave in tien delen. Edited by J.F.M. Sterck, H.W.E. Moller, C.G.N. de Vooys, and C.R. de Klerk. Amsterdam: Wereldbibliotheek, 1927-1937.

Vondel, Joost van den. 'Op den nieuwen Schouwburgh. Aen den Raedsheer Nikolaes van Kampen', 1637. In Joost van den Vondel, Gysbreght van Aemstel. Introduced and annotated by Mieke B. Smits-Veldt, p. 34. Amsterdam: Amsterdam University Press, 1994. http://www.dbnl.org/ tekst/vondoo1gysbo1_01/vondoorgysbo1_01_0016.php

Vondel, Joost van den. Inwydinge van 't stadthuis t'Amsterdam. Eds. Saskia Albrecht, Otto de Ruyter, Marijke Spies, Frank Elsing, Winny Hübben en Marianne Stegeman. Muiderberg: Dick Coutinho, 1982.

Vos, Jan. Toneelwerken. Edited by W.J.C. Buitendijk. Assen and Amsterdam: Van Gorcum, 1975.

Vos, Jan. Alle de gedichten van den PoëetJan Vos - deel 1. Amsterdam:Jacob Lescailje, 1662. http:// www.dbnl.org/tekst/vos_oozalleo1_01/

Vos, Jan. Alle de gedichten van de vermaarde poëet Jan Vos - Tweede deel. Amsterdam: Jacob Lescailje, 1671. http://www.dbnl.org/tekst/vos_002alle02_01/vos_002alle02_01_0002.php

Vossius, Gerardus Joannes. Poeticarum Institutionum libritres: Institutes of Poetics in Three Parts. Edited and translated by J. Bloemendal, in collaboration with E. Rabbie. Leiden: Brill, 2010.

Wagenaar, Jan. Amsterdam, in zijne opkomst, aanwas, geschiedenissen, voorregten, koophandel [etc.]. Amsterdam: Isaac Tirion, 1760.

Warnke, Frank J. 'Sacred Play: Baroque Poetic Style'. The Journal of Aesthetics and Art Criticism 22, no. 4 (Summer 1964): pp. 455-464.

Watson, Alan, ed. The Digest of Justinian. Volume 1. Philadelphia: University of Pennsylvania Press, 1985 .

Westermann, Mariët. A Worldly Art: The Dutch Republic 1585-1718. New Haven: Yale University Press, 1996. 
Westermann, Mariët. Amusements ofJan Steen: Comic Painting in the Seventeenth Century. Zwolle: Waanders, 1997.

Weststeijn, Arthur. 'Republican Empire: colonialism, corruption and commerce in the Dutch Golden Age'. Renaissance Studies 26, no. 4 (2012): pp. 491-509.

Weststeijn, Arthur. 'The Power of 'Pliant Stuff': Fables and Frankness in Seventeenth-Century Dutch Republicanism'. Journal of the History of Ideas 72, no. 1 (January 2011): pp. 1-27.

Weststeijn, Thijs. 'Between mind and body: painting the inner movements according to Samuel van Hoogstraten en Fransiscus Junius', Nederlands Kunsthistorisch Jaarboek 60 (2010): pp. 263-279.

Weststeijn, Thijs. 'Een feest voor het oog; lachen en levensechtheid in de zeventiende-eeuwse kunsttheorie' In Anna Tummer, ed. De Gouden Eeuw viert feest, pp. 20-28. Rotterdam: NAi, 2012.

Weststeijn, Thijs. The Visible World: Samuel van Hoogstraten's Art Theory and the Legitimation of Painting in the Golden Age. Amsterdam: Amsterdam University Press, 2008.

Williams, James. Gilles Deleuze's Difference and Repetition: A Critical Introduction and Guide. Edinburgh: Edinburgh University Press, 2004.

Worp, J.A. Geschiedenis van het drama en van het tooneel in Nederland. Deel 2. Groningen: Wolters 1907; repr. Rotterdam: Fa. Langerveld, 1972.

Yamamoto-Wilson, John R. Pain. Pleasure and Perversity: Discourses of Suffering in SeventeenthCentury England. Farnham: Ashgate, 2013.

Yates, Frances. The Art of Memory. Chicago: Chicago University Press, 1966.

Zamora, Lois Parkinson, and Monika Kaup. Baroque New Worlds: Representation, Transculturation, Counterconquest. Durham, NC: Duke University Press, 2010.

Zepke, Stephen, 'Becoming a Citizen of the World: Deleuze between Allan Kaprow and Adrian Piper'. In Laura Cull, ed. Deleuze and Performance, pp. 109-125. Edinburgh: Edinburgh University Press, 2009.

Žižek, Slavoj, The Parallax View. Cambridge, MA: MIT Press, 2006.

Žižek, Slavoj. Event. London: Penguin, 2014.

Žižek, Slavoj. For They Know Not What They Do: Enjoyment as a Political Factor. London/New York: Verso, 2008.

Žižek, Slavoj. Organs without Bodies: Deleuze and Consequences. London: Routledge, 2003. 
This content downloaded from 132.229.156.144 on Tue, 05 Feb 2019 10:43:06 UTC All use subject to https://about.jstor.org/terms 


\section{Index}

ability $18,89,190$

accident(al) 13, 20, 38

Act of Abjuration 18,65

acting (politically) 18, 29, 33, 110-111, 119, 134,

$147,149,153-55,160,167,168,178-79,183-84$, $187,188,190$

- as re-enacting / playing $35,93,162,164$, 166,168

action $33-34,37,58,63,68,77,94,100,118,123$,

$133,150,153,167-68,177,181,184,189,190$

- dramatic $28,110,116,155,167-68$

- frozen $182,187-88$

actor $22,28,31,32-33,35-37,63,70,73-74,76$,

$107,110,13,155,166,170,183,190$

- theatrical/dramatic 34-36, 47-48, 95, 106, 111, 114-18, 123-24, 155, 156-58, 16o, 171, $178-79,187-88$

- company of actors 93,96

actualization $35,44,86,165-66,179-80,194$

administration 69,73

admiral $71-72,73,76$

aesthetics 19-21, 22, 27, 30, 31, 49, 57, 92, 97,

$127-29,133,136,138,139,140,143,146,167$,

$184,188-89,191$

- and politics $22,33-34,35,37,46$

affect $22,23,25-30,49,75,76,83,85,89-90,99$,

$107,136-140,169,184-85,188-91,194$

- as that what drives $23,26-27,31,92,94$, $184,189,190$

African 38-39, 103, 106

agnitio 94

alchemy 130, 143

allegory $44-46,48-49,57,97,122,139,140-141$,

$142,154,161,168-70,186,188,192$

- allegoresis 14

- as fragmentation 140,142

- and form 140

- and science $135 \cdot 136,143,145^{-146}$

ambiguity $13,39,43,46,49,60,83,120,122,138$,

$157-58,161,163,174,177,181,195$

Anabaptism 98

anachronism 30, 46, 49, 98

anagnorosis 94,140

anatomical theatre, see theatre

angel $178-79,187$

- fallen 13

anticipation $63,178,181,183,185$

apology $87-88,95,109,111$

architecture $17,33,45,122,15-56,160,162,168$,

192-93

- of public debate 117,162

argumentation $94,117,138,156$

Aristotelian $33,88,94,141$

Arminian, see Remonstrant art $19,20,21,22,24,27,32,37,49,83,86-87,89$, 91, 92, 95-96, 99, 104, 114, 116, 120, 137, 139, $143,151,160,167,173,179,180-81,184,188,193$ artificiality $24-25,32,75,107,111,114,123,142$, 159

- as real 16-17, 24-25, 27, 32

artist $12,19,30,95,97,130,143,173$

atheism $151,154-55,160$

audience $28,33,34,59,63,73-74,76,84,86,88$, $96,100,118-119,122,126,137,140,15^{2-53}, 156$, $157,160,163,174,182,188,193$

- involvement of 27-28, 63, 83, 90, 106, 110-11, $114,116,123,177,182,185,187$

author $14,21,35,36,43,57,117,120,126,133$, 183,189

authority $46,52,62,68,75^{-7} 76,92,109,138$, $153-54,177,185$

autonomy 52,190

Baroque $16,19,22,23,26,45,46,49,82,85,87$, $9,92,94,97,99,101,104,105,127,140,163$, $164,167,168,173,176,177,180,181,191,195$

- as anomaly 19, 40, 97

- and artifice 16-18, 20, 27-28, 32, 37, 122, 142

- as attitude/ sensibility $21,22,54,86,149$, 167

- Catholic 19, 21

- and classicism 20-21, 138, 168

- colonial 39, 108

- confusion 16, 101

- interruption/moment 100, 138

- neo- 20-22

- opulence/vibrancy 17, 19, 21, 85, 101

- republican/material 17, 18, 20-22, 23-24, 30, 31-32, 35, 37, 39, 44, 57, 63, 82, 85, 87, 97, 100-01, 108, 124-25, 131, 134, 167, 173, 180,195

- paradox 16, 20-21, 144

- as period 19-20

- and the real/world 16, 20, 96-97, 100, $142-43,179-80$

- royal/princely $20,46,57,82,122$

- self-reflexivity $35,107,157$

- sublime, see sublime

- worldly 19, 21-22, 86, 95, 101, 144

Batavian myth $46-47,70$

berecht, see foreword

Bible $60,71,79,144-46,168,185$

bifurcation $30,32,35,173,194$

body $12,27,5^{8-59}, 61,77,105$

- and affect $27,90,175,184,189$-190

- and mind 89, 99, 136, 156

- natural 99, 126, 131, 141

- socio-political 18, 6o-61, 128, 150, 155 
booty $109-112$

bourse 155

burgomaster 14, 23, 52, 73, 128, 157-158

burlesque 108

Calvinism 20, 160, 194

- as state religion $32,5^{1}$

carrack 108, 110, 112

catharsis 140

Catholicism 19, 21, 44, 46, 51, 57, 58, 62-63, 67,

$149,150,193,194$

causality $78,99-100,189$

centralization 69,82

character $13-14,16,21,50,54,56,94,96,114$, $116-17,156,159-60,181-82,186$

- as real persons 33,108

chiasmus 29

choice $38,49,54,66,75,77,81,93-94,117,133$, $177,180,189,193$

chorus 187

chronicle $91,137,139,153$

church $80,91,94,144,152,155,157^{-} 5^{8}$

- state- 32, 51,67, 91

- Roman Catholic/Protestant 44, 46, 50, 51, $57,63,67,91$

city 11-12, 13-14, 113, 119-123, 146, 152-53, 160, 167 , 192-93

City Hall of Amsterdam 18, 21, 22-24, 26, 44-46, 100,155

- as Royal Palace 23

classical 21, 23, 44, 46, 65, 67, 117, 122-23, 137, $139,150,152,153,159,161,186,193$

classicism 21, 168

- neo-classicism 20

cognition 165

collective $76,79,93,105,137,149,153,155,162$, $183,192-93$

colonial(ism) 39, 43, 104, 107-08, 133, 134,

Colonies, Chamber of 154,167

- pre- $103,111,134,153$

combat $78-82$

comedic 29, 83, 86-87, 89-90, 96-97, 100

comedy $86-87,159,193$

comic(al) 54, 83, 85-89, 98, 194

commerce 109, 111, 113, 115-16, 118, 120

commonplace books/system $137-38$

commonwealth $38,45-46,50$

community $26,68,74,183$

- English 11, 191

Company

- Dutch East Indian (VOC) 74, 103, 113, 118

- Middelburg Commercial 120

- United West Indian (WIC) 39, 74, 103, 105

condensation 71,73

conditional $175^{-76}$

confederation 46,154

conscience $60,62,118$

constitution $110,162,183$

contingency $13,20,27,30,180$
- and history 20, 92

- as political/freedom 18-20, 37, 97

correlation, see: relation

counterfactual $96,98,175-77$

Counter/Contra-Reformation 19, 141

Counter-Remonstrants 31, 41-42, 51-53, 62, $69-70$

court

- of justice $69-70,118,172$

- $\operatorname{royal}_{34}, 82,93,122,128$

cruelty $27,38,55,65,75,77,78-82,134,166$,

177,193

- as dramatic 81

- logic of $64,78-82$

culture/cultural 19, 20, 22, 23, 83, 93, 94, 100,

$125,126,128,192,194$

- festive $84,164,195$

- multi- 21, 104

- and politics 104, 109, 128

curiosity cabinet/chamber 125-127, 129, 133

democratic $37,149,154$

depiction $12,24,26,29,48-49,73,74,82-83,85$,

$89,92-93,96-97,98,105,106,108,122,130$,

$134-135,157,174,179,182,183,192$

description $19,25,28,104,121,126,145,167-68$,

$181,186,187$

devil $16,42,61$

diegesis 74

disharmony see harmony

display, see theatrical

distribution $24,120,171$

dominium $38,43,5^{0-51}, 5^{2}, 57,67-68$

drama $32,33,3749,74,92,93,163-64,165,166,171$

- Early modern/baroque 32, 140, 164

- Greek 163

- as plot 33

- modern 177-78

- school- $32,150,155,156,160,162,164$

dramatic $32,41,44,49,5^{0}, 53,63,74,76,79$,

$81-82,85,97,106,107-08,109,112,117,118,119$,

$121,131,133,134,135,147,152,155,170-71,174$,

177,187

- logic of the 74,80

- in relation to platform/podium/scene $115-16,117,122-24,136$,

- as play 155,161

- in relation to political interruption or openness 37, 49, 74-75, 77, 92, 93-95, $100,110,117,167-68,173,177,179,182,186$, 190,194

- world 164, 171, 180

dramaticus, see mundus

dramatization $33,35,107,123,133,155,163,177$

- in relation to action/moment 162, 165, 179

- in philosophy 33, 35, 164-166, 168

- and politics 36-37

- porous border with theatricality 33,35 , 168,171 
dramaturgical society 153

dream 17, 104, 142, 156, 166, 169, 174

- logic/model of 97, 124, 142, 147, 171

Dutch East India Company (VOC), see Company

Dutch Republic 11, 13, 17-18, 19-21, 22, 23, 24, 25 31, 35, 36, 37-39, 41, 43, 44, 45, 46, 49-50, 51, $52,53,57,62,63,65,69-70,71,72,73,75,81$, $84,85,86,90,91,97,106,108,112-13,120,139$, $144,149,151,154,162,167-68,173,188,191,194$ - as anomaly 19, 97

- as Tower of Babel 21

earth, see world

economy 24, 26, 101, 112, 113, 119, 121, 167

emblematic 167

emotion 11, 26-29, 78, 104, 108, 134, 139, 140, 192,194

- excessiveness of 54,187

emperor 47, 54, 68-69, 137

empire $44,113,181$

- Dutch 39, 43

- Roman 44, 45, 55-56, 68,69

- translation imperii 44-45

empiricism 21, 132, 136, 139, 144-45, 170

enemy $46,68,112$

environment 11, 23, 27-28, 104, 127, 132, 160, 162

epic 14, 33, 90-92

Epicurism 157

epigram 24, 157

epistemology $25,138,165$

ethic(al) 43, 77, 99, 100, 112, 137, 164, 168, 188

European 31, 41, 44, 112, 113, 126, 127, 129, 130-31, 160

- culture 19, 22, 23-24, 39, 46, 128-29, 146, $152,173,189$,

- juridico-political $38,43,51,52-53,66-67$, $69,71,82,91$

- self and other $38,106,124,133,135$

event $11,13,17,20,28,29-31,32,33,36,72,76-77$,

$92,111,117,152,178,180,192$

- and theatricality $28-29,31-32,75,152,179$, 191-92, 194

evil (also see theodicy) 59-6o, 158-59

exchange, see trade

execution 11, 31-32, 34, 36-37, 41, 71, 79, 152, 197 expression $12,23,85,86,97,128,140,180,182$,

194

Fall of man 94

fate 58,100

father $55,75,79,174,177,185-88,192$

- caring 65, 75

- as master $38,65-71$

- of prison 76

feeling, see emotion

fiscaal 73,103

fold $17,49,84,93,94,101,123,133,147,180$

foreword, berecht 123 form(al) 21, 22, 27, 36, 46, 54, 73, 84-85, 86, 92, $93,96,116,123,127,140,142,165,166,194$

foundation(al) $20,37,65,137$

fragment $20,57,92,94,100,140,142$

frame $27,29,38,57,62,77,79,86,107,117,134$, 150, 159, 169, 179, 18o, 189,

- juridical 28, 78, 101, 111, 116

- pictorial 74, 81, 110,116, 128, 131, 133, 136

- theatrical $28,34-35,62,63,74,76,85,95$, $105,171,182$,

freedom $20,37,43,52,69,78,101,115,146,149$, $154,180,189-90$

- True Freedom 19, 57, 72

future $94,171,185,188$

Generality Lands 18

genre/generic $19,32,63,74,83,85,92,93,156$, 179

geus, see slijkgeus

God 11, 63, 65-66, 69, 94, 99, 130-31, 143, 145-46, $149-51,169,171,180$

$\operatorname{god}(\mathrm{s})$, mimicking of $13-16$

- almighty/supreme 58

- and evil 59

- source of justice/law 42, 58, 62, 81

- and reasonability 59

- source of sovereignty 58-6o, 78

- and violence 61,177

Golden Age 18, 22

Gomarists, see Counter-Remonstrants

Government 43, 69-70, 154

Grand Pensionary 41, 72, 191

guilt $61-62,78,79-80$

happiness $83,85-86,100$

harbor of Amsterdam 122-23, 155

harmony 127,146

heaven $14,17,86,15^{0}$

hedonism hèdonè 157

historiography 139

history $39,41,44-45,81,87,100,118,122,171,173$,

$179,181-82,185$

- and contingency $13,20,92$

- (in)coherence or (dis)continuity of 44, 49

- making of 91-92, 94-95, 139, 167, 183, 190

- multiplication of 194

- open/closed 30, 92, 173, 177, 187-88, 190

house 123

- master of $43,65,67-70,76,177$

- as political model $38,42-43,50-53,68-69$, 75

- of Orange, see Orange

- as economical household, oikos 51,67

humanism 136, 141

iconography/iconographic 49, 83-84

illusion $12,16-17,20,24,99,118,124,142,147$,

$150-51,163-64$

- as deception $24-25,150$ 
- theatrical 16-17, 150-51, 160-64

imagination $95-96,164-65$

- collective $149,153,155,162$

immanence $17,124,180$

immigrant 121

incompatibility, see political and world

innocence 186

inquisition $61-62$

- myth of 61

intensity $25-26,29,35,37,74,85,92,96,141,170$,

$180,188-89$

intention $18,77,140,186$

interest 151,154

interpretation $46,140,142,167,176$

- resisting 12

interruption $92,94,117,173,178,185,187-88$

intertextual(ity) $30,49,54,98,168,188$

inviolability $21,138,186$

irony $18,38,62,173$

Jew(ish) 26, 144, 160, 175

judge(ment) 52, 118, 151, 164, 185, 186, 191

judicial 51-52,69, 111-12

jurisdiction 57

just/justice $24,52,60,62,72,75^{-7} 78,80,81,82$, $113,118,183,192$

- unjust/injustice 6o, 62, 8o, 81, 186

king 16, 22, 45, 66, 69, 122, 181-82, 184, 192 knowledge 31, 125-31, 133, 134, 137-39, 162, 164-66, 176

landscape 12,122

language $115,130-31,136,141,155,161,169$

laughter $48-49,83-88,96$

- as delight 87

- as prompt 83

- ridicule/scorn 88-89, 96

law $51,53,57,65,67-68,109,113,115,145,15^{2}$

- codified 69

- common 69

- divine 51

- maritime $73,76,78$

- of nations 109, 113-14,

- natural 51, 70,109-11, 117, 127

- positive 51,114

- Roman 38, 42-43, 51,61,67,69

legal(ity) $34,43,48,53,61,68-69,71,78,101$, 113-14, 116

legitimacy $44,51,53,68$

liberty, see freedom

life $12-13,16,27,65,90,92,93,140,15^{6}, 15^{8}, 159$, 166,185

- dramatically/theatrically enacted 33,35 , $37,142-43,150,155,178,183$

- everyday $42,73,84,95-96$

- life world 108, 129, 130-31

literal(ness) 13, 62, 89, 141, 145-47, 168-69, 170, 176 literature $19,22,27,42,137,158,173$

love $54,65,83,84,90,91,95,122,127,157,164$, 186

Low Countries 22, 69, 93, 119, 120, 152

- Northern 19, 23, 36, 50, 65, 70, 75, 93, 112, 120-22, 126, 151, 192

- Southern/Spanish 19, 121

lynching of brothers De Witt 32, 37, 71, 73, 76, $79,80,91$

lyric(al) 56, 171

martyrdom $60,62,82$

master, see house

Medieval/Middle Ages 14, 32, 38, 42, 44-45, 51, $58,63,65,77,86,120-21,135,137-38,139,140$, $150,153,156,173,183$

merchant, see trade

metaphor 72, 75-76, 97, 105, 127, 131, 135-36, 143,

$149-52,161,163,168,171,183$

microscope $135,140,142-43$

military $18,31,70,113,121$

miracle/miraculous $17,23-24,54,104,127,133$

mise-en-abyme 103, 106-o8, 123, 136

mise-en-scène $37,107,116,119,124,163$

- props 36, 119

misto 21, 97

modal, see reality

modern/modernity $19,20,22,37,43,66,72,88$,

94, 99, 177, 179

moment 17, 28, 29-30, 93-94, 100, 110, 112, 116-19,

$125,142,173,176,180,181,182,187,190,192$

- and affect 29-30

- of ascendance and decline republican Baroque 31-32, 191, 195

- and double reality $17,29-30,48,86,96,98$, $100,173,179$

- and dramatic action 28-29, 32-33, 36-37, 74-77, 79, 81, 93,-94, 110-11, 117-18, 140, 171, $177-80,186-87,190,194$

- and event 29-32, 179

- in terms of intensity/time 30-31, 92, 96, $139,142,171,188,191$

- as political 29-30, 39, 71, 77, 184-85, 190

- and the sublime 85, 97

- and tableau vivant 181-85, 187-88

monad, see world

monarch, see king

money $13,25-27,103,110,119$

monstrosity 127

$\operatorname{moral}($ ity) $49,58,62,71,78,84,112,167,184,195$

- amoral 57

- as didactic 83-84, 134, 163, 194

mother 91, 186, 191, 192

mundus dramaticus 147, 164, 168, 171

museum 23, 48

- of natural history 125,127

myth(ological) 13, 16, 24, 61

- Batavian 46 
narrative $27,33,44,92,94,117,139,159,175$

- and act 178-79

- and closure/opening 92, 179

natality 37

nation(al) 5o, 74, 109, 120, 192

- inter-18, 20, 41, 6o, 109, 112-15, 120, 191

nature/natural $13,16,27,92,114,132$

- history/science 125-29,132

- preternatural 127, 133

- un- 13, 54, 146

necessity $20,38,77,78,92,97,99-100,175,177$, 180,184

neo-Platonism $86,136,15^{\circ}$

Netherlands, see Northern Low Countries

New Netherlands 154,167

novelty $14,135,164$

oikos, see house

oligarchy 18

ontology $27,116,138,165,170$

optation (also see what-if) 178, 187

Orange, house of $5^{0-51}, 72,90,19^{2}$

Orangists 79,147

order $51,63,68,78,91,94,151,179,183$

- dis- 43

organ without body 175

orphanage 48,182

orthodoxy, see religion

pain $55,59-60,63-64,73-74,77-78,82$

painting $12,21,23-27,28-29,32,48-49,62,71-77$,

$79,82-85,87-89,92-94,96-98,101,105-08$,

$122,134-35,150,157-59,173-74,178,181-82$,

184,186

- genre-19, 89, 93, 143,

papal $20,39,43,114,128,134,192-93$

paradise 86

paradox, see Baroque

parricide 68-69

passion $27,83,85,92,136-37,139,143,184$

pathos 194

patriarchy/alism $38,71,75$

peace(ful) $32,67,91,109,159$

- of Westphalia, Utrecht 113

people (a, or the) $11,22,45-47,50,52,65,66,69$,

$72,113,114,144-45,157,182-83,184,185$

- affected/dramatically or theatrically positioned $16,18,26-27,29,35,76,93$, $123-24,134,149,151,153,164,193$

performance (theatrical) 13-14, 49, 57, 93, 114,

$117,122,123,152,156,158-61,162,186,193$

- socio-politicially $34,61,116,127,133,143$, $15^{2-53}, 155,162,163,182$

performativity 179

peripeteia 94,140

perspective $25,104,107,123,131,142,147163$, 168, 192,

- and subjectivity $38,119,123,163$

- vanishing point 12, 131 planet $134,136,142$

play (theatrical) $13-14,17,37,47-49,53-54$, $56-57,63,79,91,93-95,105,119,120,122,123$, $140,142,156-61,163-64,174,178,185-88,190$ - as a form of acting in the world $13,14,16$, $49,5^{2}, 66,76,100,113,123,150,162-64$, $166,168,174,182-183,192$

- revenge- 53-55

podium (as different from stage) 74, 111, 115-16, 123,171

poem 11-12, 13-14, 24-25, 45, 46, 54, 58, 80, 98, $156-58,161,168-70,192$

poetics $38,137,177$

politics/political 19, 21, 22, 23, 31, 34, 38, 41, $46,49,51,57,9,72,73,74,76,77,90,113,153$, $166-67,191,193$

- and aesthetics $32-35,36-37,46,50,57$, $15^{0}-5^{2}, 167,188,191$

- agonistic/cruel/incompatible 64, 65, 75, $77,79,81,90,149$

- body $18,27,37,66,15^{\circ}$

- contingency/freedom 20, 29, 37, 66, 101, 189-90

- dominium vs. republic 38, 42-43, 50-51, $57,70-71$

- and moment/new 29-30, 37, 181, 184-87, 190-91

- problem of the $22,35-36,5^{0-51}$

- and religion 46, 52-53, 57, 67, 69, 91, 144-46, 184, 188

- rule/state $32,38,42-43,46,50,52,66-67$, $71,128,154,191$

- slavery 38, 43-44, 66

pope, see papal

potentia/potential 18, 27, 29-30, 35, 49, 94, 101, $15^{0}, 160,171,173,177,179,180,182-83,185,189$ power(s) $18,19,25,26,44,45,60,76,112,138$,

$15^{2-53}, 164,184$

- of affect $23,25-26,30,33,85,89-90$, $143-44,184,188$

- artificial/natural 13-14, 16-17

- balance of 18

- civic $23,32,44,52$

- divine vs human $14,16,17,58,60,75,96$, 128

- imperial/papal/royal 19, 23, 38, 43-44, $46-47,5^{0}, 57,66-67,70-72,73,128,190$, 193

predestination $20,70,92$

preternatural, see natural

prince $20,53,57,65-66,69-71,82,128-29,134$,

$183-84,191$

- of Orange $48,80,192$

print(ed text) 14, 24, 47, 48, 57, 73, 75, 123,

$153-54,157,174$

prison of Amsterdam/tuchthuis/rasp house 41, $52,73,76$

private (as opposed to public) 50, 71, 84, 97, 109, $113^{-15}, 129,150,155,160-62,188$ 
prop, see mise-en-scène

property $68,108-11,113-14,116,118-19$

prosperity 53,100

Protestant 19, 46, 50, 58, 62-63, 149

Provinces, see states

public debate $37-38,51,59,67,70,75,79-81,117$,

$151,155,158,160,192-94$,

punishment $13,41,52,68,70,72-74,76,78$

Raadspensionaris see Grand Pensionary

rasp house, see prison

rational see reason

$\mathrm{real} /$ reality $12,16,20,25,49,74,91,97,107,131$,

$136,146,151,165,170,175,194$

- as actualized 29, 32-33, 37, 82, 87, 100, 124, $165,168,175,180$

- as dream 104, 124, 147

- everyday $21,24,37,79,85,95-96,170$

- as or vs illusion 12, 14, 16-17, 25, 27, 34, 95, $97,120,150,155,161,163-64,168,170$

- material 19-20, 133, 168

- multiplicity of 12, 17, 20, 29-30, 82, 86, 94-98, 99-100, 175-77, 178-80

reason(ability) 51, 59-6o, 63, 99, 132, 145-46, 156 redemption 170

reflection $37,124,131,133,142,157,169$

Reformation 19, 50, 58, 141

Reformed church 50

regent $18,48,72,75$

relation(ship) $35,38,44-45,57,79,87,91,93,99$, $113,115,116,123,129,130,131,135-36,137,141$, $152,173,176,185,188-89,190$

religion $5^{0}, 51,141,144,154,159,164,186,188-89$

- orthodox 13, 32, 41, 62, 157, 160

- and state $31-32,51,70$

Remonstrant $31,41-42,52,70$

Renaissance $20,30,38,43,49,86,98,106$, $136-40,143,163,181,187$

repetition $21,35,60,61,77,79,165,173,178$, $182-83,188$

representation $28,63,73-74,77,79-80,106,123$, $142,146-47,182,185,187,194$

- logic of 26, 165-66

republic(an) 18, 22, 23-24, 32, 35, 36, 39, 46, 63, $65,69,70,77,79,81,82,90-91,100,108,120$, $128,149,182,195$

- see Dutch Republic

- republicanism 70-71

- Roman (also neo-) 43-44, 46, 57, 68-71, 181

res cogitans 131

responsibility 113

retrospection $61,63,177,178,181$

revolt $47,181-82,184$

revolution(ary) 22, 42, 53, 121-22, 133, 136, 143, $149,160-61,184$

rhetoric $12,25,27,71,79,112,137,138,140,15^{0}$, $15^{2}$

right $66,68-69,113-16,118,154$ royal(ty) $19-20,22,34,46,52,57,82,128,129$,

$134,181,193,194$

- royalist 52

sacrifice $174-75,177,185^{-8} 8$

satire $15^{\circ}$

scene(s) 12, 24, 28, 32, 33-34, 36, 48-49, 63, 74,

$89,95,100,103,105^{-06}, 108,110,123-24,135$,

$156,182,186,188,190$

- world as, see world

scenery $13,14,17$

scholasticism 156,183

Schouwburg see theatre

science $21,124,125-31,133-40,142-44,151,166$

sea $21,56,60$,

- free seas 101, 111, 116

- as stage/platform/podium/scene 111, 115-16, 119, 122-23

seeing (and blindness)

self-portrait 12-13

sense $20,29,35,85,97,110,129-34,136,139,141$, $143,145,161,170,190$

ship 21, 71-72, 74, 76-79, 103, 108, 111-12, 115-16,

$118-19,122-23,125$

- as actor 111, 115-16, 123

- of state, see state

sign $25,60,135,157,158,194$

- divine 11,128

- icon(ical) 28, 76, 115, 123, 173

- index(ical) 115, 142

slave(ery) 37-39, 43-44, 65-66, 67-70, 105-06, 108,195

- and terror 38,108

- political 43-44,65-66

- trade 38-39, 103, 105-06, 120

slijkgeus 42

society $21,26-27,32,61-62,73,84,146,15^{2-54}$, 157,159

- art/scientific Society 134, 151

Socinianism 94-95

sovereign/sovereignty $18,20,21,23,38,43,5^{2}$,

$53,66,70,77,113,128,192$

- diffuse/mixed 18, 69, 113

- individual/people 51, 66, 113, 138, 182-83

- patriarchal/tyrannical 38, 43

- of God 58-59, 6o, 75, 78

spectacle $16-17,71-74,76-77,79,82,122,125,129$,

$15^{2}, 163,191,192-93,194$

- $\operatorname{logic}$ of 74,193

- and power 73, 79, 128, 134, 193

- Laetium spectaculum 79

speech $36,48,77,15^{2}, 157-5^{8}$

- free 149, 154

stadholder $18,20,31,32,41,49,51,5^{2}, 72-73,81$, 90, 168, 191,

- quasi-royal 18-20, 81-82

- stadholderless period 46, 57,72

stage (theatre) $34,36,54,62,63,74,107,114,119$, $122,155-56,160,182,186$ 
- as act of staging $32,34,44,73,75,108,115$, $133,152,192,194$

- apparatus 14

- and event (re-stage) 28-29

- as/in world 44, 106, 108, 111, 115-19, 120-24, $133,150,155,164,166,168$

state(s) $18,31,41,46,50,52,53,62,69,72,76-78$, $80-82,91,109,134,152,153,154,157,158-59$, 166

- balance of terror 82

- as house(hold) 38, 42-43, 50-51, 53, 66-70, 75-76, 177

- province $11,65,71,72,120,121,191$

- and religion 31-32, 51,63, 70, 91

- as ship 72-73, $75^{-7} 6$

- sovereign $18,38,43,46,66,71,113$,

States General $18,53,65,69,72,113$

still-life 12,143

Stoicism $58,63,120,150$

story, see narrative

struggle $33,37,39,57,62,120$

style $21-22,97,145-46$

subject/ivity $12,27,58,60,62,74,87,100,119$,

$122,131,132,133,135,142,146,160,161,162$,

$174,188,191$

- knowing/observing/sensing 119, 131, 132-33, 142, 162-63, 171

- political 38, 43-44, 65-66, 68, 70, 75, 78, $177,184,189,190$

- through subjection $38,43,58,62-63,68$, $74-78,95,117,177$

sublime $29,83,85-87,89,97,100,107,194$

- comedic 85-87, 96-97, 100

- tragic 100

superstition $144,151,159$

surface (as opposed to depth) 12, 25, 136, 142, 144

symbol(ic) $51,68,115,128$

Synod of Dordt 41, 51, 62, 69-70

tableau vivant (vertoning) 152, 157, 159, 173, 181-90, 192-94

Tacitism 70

telescope $134-35,140-42,171$

territory $18,82,111$

texture $107,141,142-43,145-47,168,170,171$

theatre $22,33-36,37,73-74,93,97,105,114$, $116-18,122-23,128-31,135,137,143,15^{2}, 157$, $158,160-62,163,164,165-66,177,192-93$

- anatomical 128

- Amsterdam Theatre/Schouwburg 33, 44, 120, 155-56, 160-61, 182, 186, 194

- (English) companies 96

- as didactic tool 151,164

- medieval/early modern 17, 32, 149

- memory-129-31

- as distinct from spectacle $73-74,15^{2}, 163$, 192-93

- state 152
- and world 97, 135, 143, 161-63

theatrical

- absorption 35

- display $16,63,74,79,81,128,129,133,138$, $152,160,187,193$

- logic of the $74,80,118,128-31,140,165$

- society/worldview $135,15^{2-53}, 155,160$

- role $35^{-36}, 120,124,15^{0}$

theatricality

- and alienation 34, 18, 109-10, 117, 123

- and audience/staging/acting 34, 116-17, $119,123,143,155,162-63,166,171$

- and event, see event

- dynamic with drama(tization) 36-37, 107, $112,133,163,166,168,171,177,179$

- and power/politics 36-37, 152-53, 192

theatrum mundi 128, 130, 131, 143, 147, 149-52, $161,163,168,171$

- chemicum 130

- naturae or sapientiae 126, 130-31

- violentiae 79

theodicy $59,62,67$

tolerance 21

torture $13,41-42,50-54,56-57,60,62,67,71,76$,

$78,80,177$

- and Inquisition 61-62

- logic of $60-64,77-80,177$

- and political model of dominium 38, 41-43, 51-52, 57, 62, 67-70, 77-79, 177

- and world 61-63

trade/exchange 19, 21, 46, 106, 108-13, 115-16,

$118-20,122,125$

- slave- 38-39, 103, 105-06, 120

tradition $43,137,143,146,156-57$

tragedy $49,54,57,79,86,163,186-87$

tragic $17,29,32,47,54,87,90,94,11,166$

transcendence 82

trauma $31-32,76,164$

treasury of Amsterdam 23-25

trompe l'oeil 12, 23, 25-26

trust/trustworthiness $27,59,113$

truth $143,150,156,161,163-64,170$

tuchthuis, see prison

tyrant/tyranny $14,38,42-44,46,55,65-66$, 181-82

unity of time /place /plot 54 universe $99,127,130,133-36,139,141-43,153,160$ university

- of Amsterdam 137

- of Leiden 189

utopian 79

vengeance play $54-55$

victim $28,32,61-62,105,179$

violence $15,42,45,54,65,78,79,98,182$

- of ruler/state 82,183

virtual $165-166,168,178-80$

virtue/virtuous $30,44,60,183-84,186,190$ 
virtú $183-84$

VOC, see Company

voice $146,175,187$

- active/passive 119

war $15,125,186$

- Dutch-English 11, 108

- Dutch-Spanish 18, 108-o9, 112-13

- private 113

what-if 96, 98-99, 173-74, 177, 180, 187

WIC, West Indian Company, see Company

world(s) 12, 14, 16, 17, 20-27, 29, 30, 32, 33, 35,

37,45

- bifurcation of $30,32,35,173,194$,

- closing of 29, 32, 37, 63, 65, 75, 82, 180 , 187,190

- coexistence/fusion/simultaneity of 29-30, 49, 77, 90, 95, 98-99, 100, 147, 168, 176, 177,180

- collision of 95, 97, 108, 134
- elimination/unmaking of $13,17,61,63$, 77,82

- as earth 15-16, 86, 95, 135-36, 141, 150, 169

- ensnarement with $26,136,143,144$

- incompatibility of $37,41,57,64,65,75,77$, 81,183

- interpretation of $136,142,176$

- monad 99, 143, 180

- multiple/plurality of 11, 17, 20, 29-30, 82, $175^{-80}$

- natural 16

- new/opening 22, 29, 33, 36-38, 38, 65, 75, $95,101,104,108,119,134,142,150,154,161$, 166,167

- New 29, 154, 167

- possible $12,20,58,62-63,86,94,95,99$, $100,176-77,180$

- as scene $22,33,108,111,116,119-20,123$, 162,167 


\section{Index of names}

Aa, A.J. van der 24

Abraham 21, 173-80, 186-87, 198-99

Adorno, Theodor W. 161

Aeneas 13-14

Africa 103

Agamemnon 186

Ahmed, Sara 27

Albach, B. $34,96,182$

Alpers, Svetlana 25,167

Alphen, Ernst van 27, 169

Althusius, Johannes 51,66

Althusser, Louis $35-36,139$

Amalia van Solms 48-50, 192

Ambon 125-127, 130, 133

Amsterdam 14, 18-19, 21-26, 33-34, 41-47, 52, 54, $62-63,76,80,91-92,96-97,100,103,107,109$, $111,113,119-23,128,137,146,149,151,154-56$, 158, 16-61, 164, 167, 182, 191-92, 194, 197-98,

Anklitz, Konstantin (Black) 13-16

Anonymous 80

Antwerp 120

Aquinas, Thomas 51, 59, 79

Aran, and Titus Andronicus 53-57

Arasse, Daniel 30, 49

Arendt, Hannah 36-37, 51, 67, 167

Aristophanes 193

Aristotle $33,88,94,141$

Arnade, Peter 152

Astell, Ann W. 140

Atkins, Christopher D.M. 19, 83

Attridge, Derek 169

Augustine 131

Augustus 68

Baay, Reggie 39

Bacon, Francis 133

Badiou, Alain 29-30, 124

Baen, Jan de 77, 197

Bainton, Ronald H 62

Bakker, Boudewijn 121

Bal, Mieke 22, 29, 119, 185-86

Bali 152-53

Bar, Ludwig von 69

Baraz, Daniel 77-78

Barca, Caldéron de la 122, 142

Barend-Van Haeften, Marijke 103

Barlaeus, Caspar 54, 137

Becker, Jochen 192

Beekman, E.M. 129

Benjamin 174, 198

Benjamin, Walter 17, 32, 94, 100, 140, 142, 16o-61, 163

Bennett, Jim, Michael Cooper, Michael Hunter \& Lisa Jardine 135

Benoist, Alain de 66
Bergson, Henri 31

Berkeley 136

Berlant, Lauren 27

Berlin, Isaiah 189

Bernard of Sylvestris 14

Bie, Jan Pieter de \& Jakob Loosjes 41

Biesboer, Peter 89

Binder, Franz \& Nornert Scheeloch 105-06

Bindman, David 106

Black, see Anklitz

Blackburn, Robin 39

Blake, William 173

Bleeker, Maaike 117, 162-63, 171

Blockmans, Wim \& Walter Prevenier 152

Blom, Hans W. 129, 189

Bloom, Harold, Neil Heims \& Heather

Dubnick 173

Blumenberg, Hans 135

Bobbit, Philip 113

Bodin, Jean 38, 66

Bohn, Babette \& James M. Saslow 19

Bon, Arnold 11

Bono, James J. 130

Borch, Olaus 151, 154-55

Bostoen, Karel 103, 105-06

Boxhorn, Marcus Zuerius van 70

Boyajian, James C. 109

Braake, S. ter 73

Braekman, Willy L. 54

Braider, Christopher 22

Brandt, Geeraardt 47-48, 91

Brazil 39

Brecht, Bertolt 33

Breen, Keith 67

Brisé, Cornelis 23-27

Brom, Gerard 21, 94

Brooks, Douglas A. 93

Brutus 181-84

Bryant, Levi R. 136

Bryson, Norman 26, 143-44

Buat $73,80-81$

Buchanan, George 186

Buci-Glucksmann, Christine 16

Burgersdijk, Franco 189

Bussels, Stijn 193

Caenegem, R.C. van 68-70

Calvin 58,62

Camerata Trajectina 42

Cammen, Hans van der \& Len de Klerk 121-22

Campanella, Thomas 132

Carl, Klaus H. \& Victoria Charles 19

Carlson, Marvin 37

Carravagio 173

Cassimir, Jean Dominique 134 
Cavazza, M. 134

Cerutti, Wim 62

Chapman, H. Perry 77

Charles I 192

Charles II 73, 191

Christian, Lynda G. 149-50

Cicero 183

Circe 122

Claudius 47,49

Clement XI 134

Coelen, Peter van der 174

Cohen, Esther 67

Coleridge, Samuel 139

Collins, Christopher 142

Conan, Michel 20

Constantine 9o-92

Coornhert, Dirck Volckertszoon $52-53,58$

Cordes, Rudolf 80, 96, 192

Correa, Helena 106

Cosimo III de Medici 129

Coster, Vincent 194

Cover, Robert 82

Creti, Donato 134-35

Cromwell, Oliver 191

Dante 86

Dapper, O. 34

Daston, Lorraine 127, 133

Davids, Karel 24

Davis, Tracy 34

Dekker, Rudolf $84-85,89$

Dekkers, Geertje $5^{0}$

Deleuze, Gilles 17, 25-26, 33, 35, 64, 78, 82, 94, 100, 136, 143, 164-66, 167-68, 179-80, 184, 189

Delft 11-13, 17, 23, 28, 128, 175, 180, 197

Delminio, Camillo 129-30

Dermoût, Maria 133

Derrida, Jacques 30

Descartes, René $59,130-32,136,151$

Deursen, A.Th. 31, 50-51

Dillen, J.G. van 42

Dixhoorn, Arjan van 152-53

Dordrecht 120

Earle, T.F. \& K.J.P. Lowe 106

East Indies $125^{-2} 6$

Eecke, Christophe van 16

Egginton, William 22

Elis, isle of $13^{-15}$

Elmina, St. George d' 103, 105-06

Emsley, Clive 53

Enden, Franciscus van den 21, 149-62, 164, 166-67

Engelen, Marcel van 103

Epicurus 157

Erasmus 141, 164

Etna $55^{-56}$

Europe 19, 22, 23-24, 31, 38-39, 41, 43-44, 46, 51-53, $66-67,69,71,82,87,91,106,112-13,124,126-31$
Fabritius, Carel 11-12

Fajardo, Diego de Savedra 151

Fausta 91

Féral, Josette 34

Filmer, Robert $66,70,75$

Findlen, Paula 127-28, 139

Fischer-Lichte, Erika 32, 149-50

Focquenbroch, Willem G. van 21, 103-08, 195

Foucault, Michel 189-9o

Carasso-Kok, Marijke, Maarten R. Prak \& Nienke Huizinga 121

Frederick Henry 18, 20, 46, 48-49, 90

Fremantle, Katherine 45

Freund, Peter E.S. 153

Frijhoff, Willem 23, 121, 192

Galilei, Galileo 122, 141, 143

Garrett, Don 164-65

Gates jr., Henry Louis 106

Geerdink, Nina 192

Geertz, Cliffford 152-53

Gelder, Roelof van 128-29

Gelderblom, Arie Jan 52, 103

Gemert, Lia van 53,187

Ghana 103

Gibbs, G.C. 24

Gilead 185

Glissant, Édouard 38

Glucklich, Ariel 6o-61

Gnapheus 164

Goetschel, R. 175

Goldcoast 103

Gracian, Baltasar 127

Greenfeld, Liah 112

Gregg, Melissa \& Gregory J. Seigworth 25

Grevius, Johannes 38, 41-43, 51, 67, 71

Grootenboer, Hanneke 12, 25, 119, 163

Grotius, Hugo 44, 47, 70, 90-91, 101, 103, 109-12, 113-19

Haarlem 98, 120

Haeger, Barbara 83

Halpern, Richard 37

Hals, Frans 21-22, 29, 82-89, 93-101, 167, 195, 197-98

Hamlet 93, 95, 181

Hanafiji, Zakiya 97,127

Hannam, James 135

Hartkamp-Jonxis, Ebeltje 21

Heemskerck, Jacob van 109-12

Heller Roazen, Daniel 132-33

Helmers, Helmer 44, 54

Heppner, A. 181-82

Hercules 159

Herklotz, Ingo 125

Hills, Helen 22

Hobbes, Thomas 43, 66

Hofstede de Groot, Cornelis 93

Hollander, August den 
Hooft, P.C. 47, 139

Hoogh, Pieter de 107

Hooke, Robert 134-35

Hooper-Greenhill, Eilean 128

Hoorn, Anna van 157

Horswell, Michael J. 20-21

Houbraken, Arnold 12

Hume, David 136

Huydecoper, Joan - lord of Maarseveen 14

Huygens, Christiaan 136, 142

Huygens, Constantijn 23, 149, 168-71

Ifis $185-86,188$

Iphigenia 186

Isaac $21,137,173-75,178-80,187-88,198-99$

Israel, Jonathan 144-45, 151, 189

Ittersum, M.J. van 109

Jackson, H.J. 139

Jacob 174, 198-99

Jacob, Margaret 21

Jameson, Frederic 119

Janssen, Johannes 41

Jay, Martin 143

Jephta $185^{-88}$

Jesus Christ 58, 94, 170

Job 21, 41, 57-63, 173, 177

Joly, Bernard 130

Jonctys, Daniél 57

Jonghe, Clement de 174

Jorink, Eric \& Dirk van Miert 137

Jorink, Eric 11, 125-27, 130, 135-36, 137, 144, 151, 189

Joseph 24, 91, 174

Jupiter 134,136

Kahn, Paul W. 77

Kamen, Henry 61

Kaplan, Benjamin J. 62

Kaspi, Joseph ben Jacob 175

Katritzky, Peg 69

Kierkegaard, Søren 173

Kievit, Johan 73, 79

Kimbrough, Erik O. 110

Kleiner, Fred S. 19

Knüpfer, Nicolaus 41,48

Kolfin, Elmer 83

Koning, Abraham de 186 Korsten, Frans-

Willem 21, 138, 16o, 186

Kramer, W. 21

Kroon, Andréa 21

Lambert, Gregg 22, 94, 100

Langbein, John 53

Langford, Michelle 140

Large, P.J. 169

Lear, Floyd Seyward 68

Legendre, Pierre 124

Lehman, Hans-Thies 33, 177
Leibniz, Gottfried Wilhelm 17, 59, 86, 94, 99, $143,176,179-80$

Leiden 120

Leo, Russ 137

Leuker, Maria 130

Levack, Brian P. 42

Levillain, Charles-Edouard 70

Lewis, David K. 176, 179-80

Lissenberg, Elisabeth $5^{2}$

Locke, John 66, 71

Loh, Maria H. 21

Longinus 85

Louis Philippe 160

Louis XIV 149

Lucifer 13-14, 16-17, 91

Lucretia 181

Luigi Marsili of Bologna 134

Luther, Martin 58, 94, 194

Lütke Notarp, Gerlinde $83-84$

Machiavelli, Niccolò 30, 51, 151, 183-84

Mack, Michael 96

MacKenzie, Iain \& Robert Porter 35

Macropedius 164

Mahoney, Michael S. 136

Maimonides 59, 145

Mander, Karel van 85

Mandrou, Robert 22

Maradona, Diego 189-9o

Mars 134, 136, 142

Marsilius of Padua 51,67

Martin, John Rupert 21

Maurits 18, 31-33, 41, 51, 53, 70, 90

McGavin, John 153

McGrath, Alister E. 62

Meillassoux, Quentin 20

Mellor, Alec 41

Mérot, Alain 20, 127

Mertens, Frank 149, 151, 156

Messalina 47-50

Meuse 71

Meuwese, Mark 106

Milton, John 66

Mitchell, W.T. 173

Moerkerken, P.H. van 160

Moluccas 125, 131, 133

Mommsen, Theodor 67

Mooney, Edward F. 173

Moreelse, Hendrick 121

Mortimer, Sarah \& John Robertson 95

Moses 145

Moss, Ann 137-38

Mouffe, Chantal 37

Nadler, Allan 164

Nadler, Steven 160

Nagel, Alexander 30, 49

Naya, Juan \& Marian Hillar 62

Ndalianis, Angela 22 
Negri, Antonio 19

Nellen, Henk 91

Nes, Aert Jansse van 71

Nes, Jan Jansse van 7 71-72 $^{-}$

Netanyahu, Benzion 61

Nevitt, H. Rodney 83

the New Netherlands 154, 167

Nierop, Henk van 53

Nietzsche, Friedrich Wilhelm 20, 163

Nyquist, Mary 38

Obadiah 146

Odysseus 122

Oldenbarnevelt, Johan van $31-34,41,52$

Ors, Eugenio d' 100

Oudaen, Joachim 79-80, 91, 161-62

Overbeke, Aernout van 103

Ovid 114-15, 186

Paalvast, Peter 53

Paijmans, Marrigje 168

Panhuysen, Luc 73

Paris 149, 160

Parish, Helen 42

Pauw, Reinier 52

Peter the Great 129

Peters, Edward 53, 61-62, 67-68

Philedonius $150,156-57,159,161$

Philip II 18, 65, 69, 120

Philip III 181

Philip IV 122

Philodemus of Gadara 157

Pieters, Jürgen 58,168

Pike, David Lawrence 14

Plato $72,76,165$

Platt, Peter G. 125

Pliny $125-26,138$

Pocock, J.G.A. 30

Poel, Egbert van der 28-29, 197

Poelhekke, J.J. 49

Pölönen, Jane 69

Porter, Robert 35

Portugal 103, 106, 108-11, 113, 125, 176

Postlewait, Thomas 34

Postma, J.M. 103

Price, Leslie J. 18

Prud'homme van Reine, R.B. $32,72-73,80$

Quast, Pieter 173, 181-82, 184

Rancière, Jacques 37

Reinders, Michel 75-76, 80

Rembrandt 11, 21-22, 173-79, 198-99

Robertson 95

Roemer, Bert van de 128 -29

Rome 33, 41, 44-47, 50, 57, 58, 62, 150, 183, 192-93

Roscam Abbing, M.V. 174

Rotterdam 42,57, 71, 73, 120

Rousset, Jean 21
Rumphius, Gerhard Everhard 21-22, 125-34, 195

Ruys, Hugo 121

Ruyter, Michiel de 71, 76

Salmoneus $13-17$

Samson 98

Sapma, Dominicus 41-42

Sarrazac, Jean-Pierre $177,185,187$

Saturninus, see Aran

Sawday, Jonathan 128

Scarry, Elaine 61, 77

Schama, Simon 84

Scheiner, Susan 58

Schiller, Noël 83, 97

Schmidt, Benjamin 57, 127

Schochet, Gordon J. 71

Schoemaker, Kees 48

Schramm, Helmar 17

Seneca 114

Sennett, Richard $15^{\circ}$

Sepper, Dennis 131

Servetus, Michael 62

Shakespeare, William 54, 120

Shapiro, Gary 164

Sidney, Philip 87-89, 95

Sierhuis, Freya $3^{1}$

Silius, see Messalina

Silverman, Lisa 53

Simmel, Georg 37

Sinck, Lucas 121

Singer, Peter 61

Skinner, Quentin 38, 43, 66-67, 69, 184

Slive, Seymour $85,89,93$

Small, Graeme 152

Smits-Veldt, Mieke B. 34, 182, 186

Soetens, Cornelis 13

Solomon 145

South Sea 123

Sozzini 94

Spanks, Jennifer \& Charles Zika 11

Spierenburg, Pieter $5^{2,}, 76$

Spies, Marijke 23-24, 92, 192, 194-95

Spinoza, Benedict de 19, 21, 26-27, 86, 90, 94-95, $99-100,113,125,136,143-47,153,160,164-65$, 179-80, 184, 188-89, 195

Staets, Hendrick 121

Stalpaert, Daniel 122, 198

Steen, Jan 87-89, 96

Sterck, J.F.M. 156

Stipriaan, René van 33, 150, 163-64, 195

Stoichita, Victor Ieronim 107

Stuart, Mary Henrietta 191-94

Tacitus 70

Tarquinius, Lucius 181,183

Tarquinius, Sextus 181

Terence $159-60$

Tesauro, Emanuele 97

Thamera, see Aran 
The Hague 18, 36, 73, 77, 79, 179, 191

Thiel, Pieter J.J. van 93, 98, 181

Thucydides 116

Tiber 45,56

Timanthes 186

Titus Andronicus, see Aran

Torrentius, Johannes 62

Trivas, Numa S. 89

Tromp, Cornelis 73

Tummers, Anna 19, 84, 86, 89

Uitman. J.E. 182

Utrecht $113,120,121,198$

Varro 131

Velasquez 182

Velde, Jan van de II 98

Verberckmoes, Johan 84

Verbrugge, Rita 170

Verdonck, Pieter 98-99

Vergil 13,114

Verschaffel, Bart 192-93

Verschuier, Lieve 21, 71-77, 79, 82, 197,

Vetruvius 121

Vighi, Fabio \& Heiko Feldner 189-9o

Vink, Markus 21

Vlaardingebroek, Pieter 45

Vlooswijck, Cornelis van 157

Vlooswijck, Nicolaes van $157-58$

Voltaire 180
Vondel, Joost van den 13-16, 21, 24, 33, 41, 44, $45-49,54,58-60,87,90-92,93-94,120,123$, $156-59,161-62,173,185,188,195$

Vos, Jan 21-22, 53-54, 56-57, 173, 186-88, 192-95

Vossius, Gerardus Joannes 21, 87, 92, 125, 136-39

Warnke, Frank J. 170

Westermann, Mariët 19, 83, 86, 89

Weststeijn, Arthur 43, 46

Weststeijn, Thijs $83,86,89$

William I, Dutch king 23

William II 18, 70, 73, 91, 168

William III 18, 32, 36, 70, 73, 81-82, 91, 191-92

Williams, James 78

Wilre, Dirck 105-06

Winkel, Jan te 202

Wit, Pieter de 105

Witt, the brothers Johan \& Cornelis de 19 , 32-33, 36-37, 57, 65, 71, 72-77, 79-81, 91, 191, 195

Wood, Christopher S. 30, 49

't $Y 45,123$

Yamamoto-Wilson, John R. 63, 77-78

Yates, Frances 130

Zamora, Lois Parkinson \& Monika Kaup 22, 39

Zepke, Stephen 165

Žižek, Slavoj 30, 119, 175, 189-90

Zoet, Jan 8o, 96 